Universidade de São Paulo

Programa de Pós Graduação em Arqueologia

Museu de Arqueologia e Etnologia

Orientador: Prof ${ }^{\circ}$ Dr$^{\circ}$ Eduardo Góes Neves

\title{
O Formativo e os Modos de Produção: Ocupações Pré-ceramistas no Alto Rio Madeira - RO
}

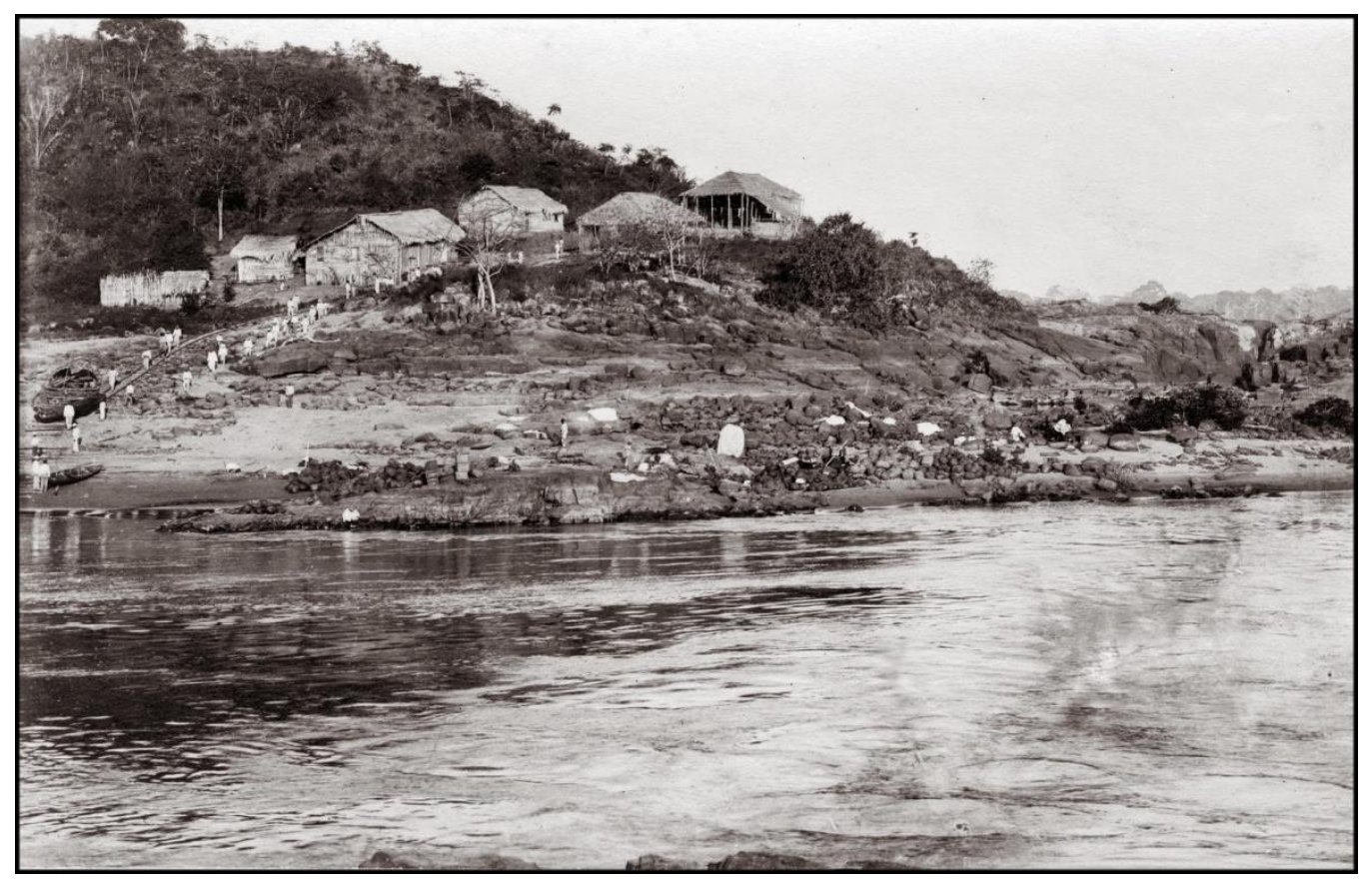

GUILHERME ZDONEK MONGELÓ 


\author{
UNIVERSIDADE DE SÃO PAULO \\ MUSEU DE ARQUEOLOGIA E ETNOLOGIA \\ PROGRAMA DE PÓS-GRADUAÇÃO EM ARQUEOLOGIA \\ Guilherme Zdonek Mongeló
}

\title{
O Formativo e os Modos de Produção: Ocupações Pré-ceramistas no Alto Rio Madeira - RO
}

Dissertação apresentada ao Programa de Pós Graduação em Arqueologia do Museu de Arqueologia e Etnologia da Universidade de São Paulo para a obtenção do título de Mestre em Arqueologia.

Área de Concentração: Arqueologia

Orientador: Professor Doutor Eduardo Góes Neves

Linha de pesquisa 2. Espaço, Sociedade e Processos de Transformação no Registro Arqueológico.

Versão revisada. A original encontra-se na Biblioteca do MAE 


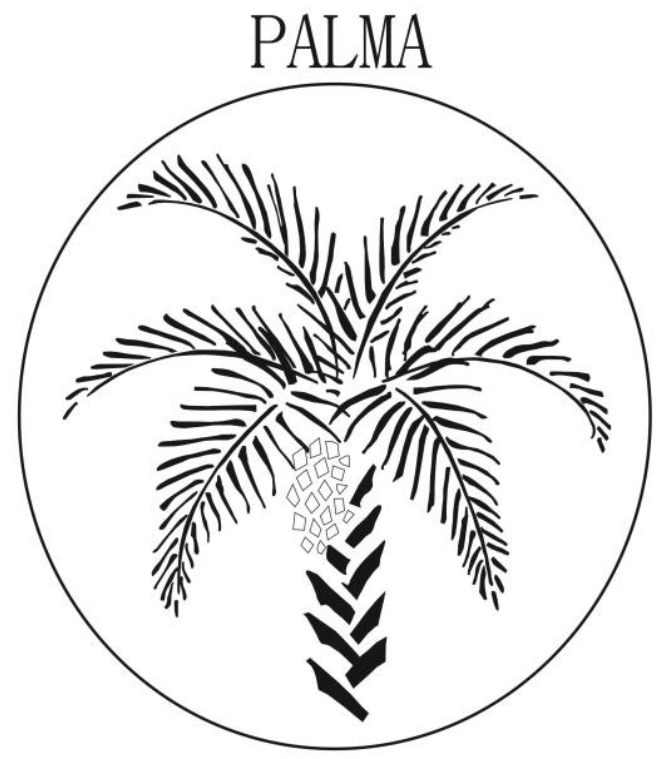

Projeto Alto Madeira 2008

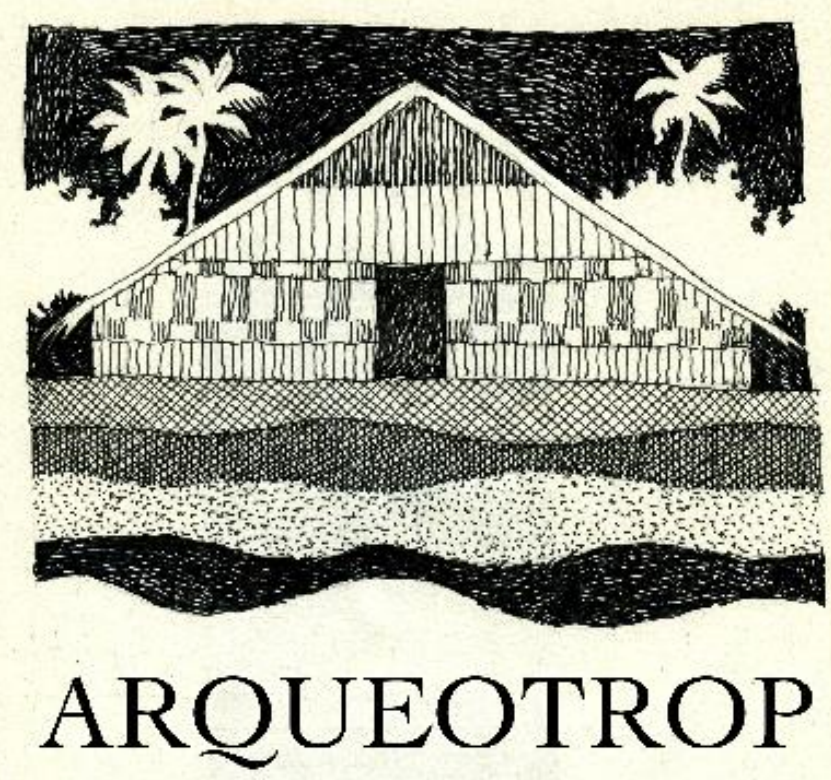

laboratório de arqueologia dos trópicos 
"Entretanto, seremos ainda cientistas, se nos desligamos da multidão? Os movimentos dos corpos celestes se tomaram mais claros; mas os movimentos dos poderosos continuam imprevisíveis para os seus povos. A luta pela mensuração do céu foi ganha através da dúvida; e a credulidade da dona-de-casa romana fará que ela perca sempre de novo a sua luta pelo leite. A ciência, Sarti, está ligada às duas lutas. Enquanto tropeça dentro de sua bruma luminosa de superstições e afirmações antigas, ignorante demais para desenvolver plenamente as suas forças, a humanidade não será capaz de desenvolver as forças da natureza que vocês descobrem. Vocês trabalham para quê? Eu sustento que a única finalidade da ciência está em aliviar a canseira da existência humana. E se os cientistas, intimidados pela prepotência dos poderosos, acham que basta amontoar saber, por amor do saber, a ciência pode ser transformada em aleijão, e as suas novas máquinas serão novas aflições, nada mais. Com o tempo, é possível que vocês descubram tudo o que haja por descobrir, e ainda assim o seu avanço há de ser apenas um avanço para longe da humanidade.”

Bertold Brecht - trecho da peça "Vida de Galileu Galilei (1938-1939) 


\section{AGRADECIMENTOS}

Não são poucos os trabalhos acadêmicos que são feitos a muitas mãos. Este não é diferente. Espero dar conta, nestas linhas, dos meus sinceros agradecimentos de todos que contribuíram para a finalização desta dissertação.

Em primeiro lugar, gostaria de agradecer ao Prof. Eduardo Neves, meu orientador, que abriu as portas do Laboratório 1 e prontamente me inseriu no Projeto Amazônia Central, este grande coletivo de grandes amigos e arqueólogos. O agradeço pela confiança, pela amizade, simplicidade e pelos inúmeros momentos de aprendizagem. Sua clássica frase sobre a "mosca azul" nunca foi tão verdadeira, a arqueologia foi a febre que peguei e que certamente nunca me curarei.

Agradeço também aos colegas de arqueologia amazônica que passaram tanto pelo PAC como pelo ARQUEOTROP, todos de alguma forma foram meus professores: Kazuo e Márjorie, Thiago "Pitoco" (grande parceiro de mestrado em Rondônia) Jaque Beletti, Felippo e Marta, Ceará e Carol, Anne e Claide, Francine, Maurício, Silvia, Carla, Jaque Gomes, Bernardo, Pupunha, Merrinha, Marcio “papai”, Chico, Pexe, Gabi, Jennifer, Poveron, Tijolo e Erêndira. Tive ainda, duas estagiárias, as quais tenho certeza que tiveram momentos importantes junto à equipe do PALMA: Helena Santana e Kollontai Diniz.

Aos colegas de Projeto Alto Madeira, que contribuíram tanto nos campos como na elaboração de diversas das interpretações que estão aqui presentes: Rodrigão, Breno, Rafael, Michelle (que levou a cabo as análises químicas de solo e participou ativamente de todos os campos), Thiago "Taubaté" (grande amigo, fez grande parte das análises qualitativas do material cerâmico sozinho), Myrtle (contribuiu com uma bibliografia considerável sobre antropologia econômica), Laura e Manu, que realizaram as análises de vestígios paleoetnobotânicos e gastaram energia, dinheiro e paciência nas campanhas de escavação. Agradeço também ao Fernando Almeida, grande incentivador para a criação deste projeto, e certamente a pessoa que mais contribuiu para a sua realização. Se há pontos positivos na minha carreira acadêmica, parte deles certamente compete à sua proximidade.

Aos companheiros da UNIR, professores e alunos, que disponibilizaram além de recursos financeiros, disposição para trabalharem em campo: Silvana, Carlos Zimpel "Guto", Eduardo "Chumbinho", Valéria, Juliana, Cleiciane, Alyne, Brena, Odair, Natiele, Andreia e Róbson Ravani, Laura, Rosane, Felipe e família (por abrirem as portas do sítio na cachoeira do Teotônio), Carreirinha e tantos outros colegas que passaram pelos dois sítios-escola organizados em 2013.

Aos colegas do MAE, onde juntos construímos dois eventos internacionais, e que contribuíram para dar outro sentido à palavra "coletividade" na arqueologia brasileira: Meliam, Aninha, Juca, Débora, Milena, Pedro, Tati Bina, Marcinha, Marina, Rafael S; 
Davi, Bruno S, Bruno P, Mariana, Letícia C, Leticia R., Paty Marinho (mais uma dissertação de mestrado pro Morro do Querosene!), Fabi Belém, Duane, Gabi, Vinicius M. e Fabio. Aos cumpas do Pedra no Estilingue, Chico Stucchi, Raoni Valle, e Camila Jácome, por dividirem as pauladas, tanto as que distribuímos, como as que levamos.

Aos funcionários do Museu, que contribuíram de diversas formas para essa dissertação, mas com os quais também dividi momentos de angustia e exaltação durante várias mobilizações e greves: Regivaldo, Gilvan, Aline, Cléberson, Kléber, Viviane, Paulinho, seu Marinho, Regina, Karen, Renatão, Judith, Hélio, Dna Nice, Conceição e Nicácio.

Aos companheiros Bruna Rocha e Vinicius Honorato que me inseriram em um debate essencial para essa dissertação, mostrando o real valor da práxis arqueológica no Rio Tapajós. Na beira do sítio Sapucaia entendi que a abundância não é uma característica específica do Teotônio, é pan-amazônica. Aos grandes amigos que lá fiz, seu Pedro, Dna Odila e todos os integrantes da família Braga, seu Josue e família, Juarez Saw e a todos os indígenas Munduruku que resistem bravamente às investidas colonialistas do estado brasileiro. Vinicius foi ainda um importante interlocutor na etapa final de interpretação da tecnologia lítica.

A todos os professores do MAE, em especial aos professores Paulo de Blasis e Astolfo Araujo, cujas contribuições no exame de qualificação foram essenciais para dar um rumo à finalização. Aos professores Randall McGuire e Henry Tantaléan, que além de ministrarem instigantes cursos sobre o materialismo-dialético, me cederam uma quantidade grande de bibliografia até então inacessível.

Agradeço a complacência na reta final de Thiago Oliveira, Juliana Mantovani e Ricardo Oliveira, meus companheiros de casa, que deram todas as condições materiais para criar um ambiente aconchegante para a redação final.

Por fim, agradeço a minha família, que melhor do que ninguém personificou a palavra "suporte", impossível mensurar seu apoio. Grande parte da segurança em escrever uma narrativa histórica sob a ótica marxista vem de suas contribuições, seja pelo exemplo de militância ativa, seja pelo constante incentivo à leitura especializada. 


\section{Resumo:}

Essa dissertação procura levantar novos dados acerca das ocupações pré-coloniais na bacia do Alto Rio Madeira, com ênfase nos trabalhos realizados no Sítio Cachoeira do Teotônio, município de Porto Velho, Rondônia. Neste sítio, foi evidenciada uma estratigrafia de longa cronologia, que remonta, pelo menos até o Holoceno Inicial, perpassando pelo Holoceno Médio e chegando até os estratos cerâmicos recentes. Nesse trabalho, procuraremos entender de que forma os processos de transformação socioeconômica influenciaram, ao longo do tempo, mudanças tecnológicas das populações que habitaram a Cachoeira do Teotônio, com destaque para o contexto denominado Período Formativo, que corresponde, no Alto Madeira, à Fase Massangana. A partir dos dados, se discutirá acerca da utilização conceitual do termo Período Formativo, buscando alternativas ao modelo de periodização histórica.

Palavras-chave: Arqueologia Amazônia, Teotônio, Fase Massanaga, Período Formativo, pré-cerâmico

Resume:

The object of this dissertation is to present new data about pre-colonial contexts in Upper Madeira River, with emphasis on the information researched at Teotonio Falls Site, Porto Velho city, state of Rondonia. In this site, was evidenced a long crono-strata that goes beyond the Initial Holoce, passing through the Medium Holocene and reaching to the recent ceramic contexts. Our propose is to understand in which ways changes in socioeconomical processes influenced technological changes in the history of the populations that habited Teotonio Falls, ,stressing the Formative Period context, that in the Upper Madeira Basin correspond to the Massangana Phase. From de discovery of new information, we will discuss the concept utilization of the Formative, looking for alternatives models to characterize history processes.

Key-words: Amazon Archaeology, Teotônio, Massangana Fase, Formative Period, prepottery 


\section{Sumário}

1- Introdução

pp. 11

1.1 Notas Preliminares

pp. 11

1.2 A Arqueologia do Alto Rio Madeira - do PRONAPA ao PALMA

pp.13

1.3 Eurico Miller e os dados iniciais da arqueologia rondoniense

pp. 17

1.4 Miller e o Formativo: A Fase Massangana

pp22

Capítulo 2 - A Revolução Neolítica e o Período Formativo: o que são e o que significam.

pp.26

2.1 A Revolução Neolítica e o materialismo-histórico na Arqueologia

pp. 27

2.2 O Período Formativo - Definições na América do Norte

pp. 43

2.3 Willey \& Phillips e a consolidação do Formativo

pp. 60

2.4 O Formativo nas Terras Baixas

pp.69

Capítulo 3 - 0 Sítio Cachoeira do Teotônio

3.1 A Cachoeira do Teotônio: palimpsestos e uma história de longa duração

pp.76

pp.76

3.2- Etapa de Campo - Diferentes Perguntas, diferentes abordagens

pp. 81

3.3 - I Sítio- Escola Cachoeira do Teotônio - FEV/2013

pp. 86

3.4 - II Sítio Escola Cachoeira do Teotônio - JUL-AGO/2013

pp. 97

3.5 - Análise preliminar de camadas estratigráfica

pp107

3.6 - Datações: dados e análise preliminar

pp.109

Capítulo 4 - A Análise dos Vestígios Arqueológicos

pp. 112

4.1 - Metodologia de Análise

pp.112

4.2 - Análise dos vestígios arqueológicos da campanha FEV/2013

pp.116

4.2.1 Perfil Leste das Unidades N10030 E9987/ N10045 E9987 e Perfil Norte da unidadeN10045 E9987 E9987

pp125

4.3 Análise dos vestígios arqueológicos da campanha JUL/AGO- $2013 \quad$ pp.130

4.3.1 Análise do Material cerâmico da Unidade N10041 E9955

pp131

4.3.2 Análise do Material Lítico da Unidade N9882 E10022

$\mathrm{pp} 142$

4.4 Discussão dos dados

pp .149

Capítulo 5. Há História sem Formativo?

pp.156

4.1 As Terras Baixas e o Modo de Produção de Parentesco

pp. 164

Bibliografia

pp. 180

Anexos

pp195 


\section{Índice de Figuras}

Figura 1 - Tabela das ocupações pré-ceramistas na bacia do Alto Rio Madeira e Rio Jamari

Figura 2. Desenho esquemático do entendimento materialista-dialético das dinâmicas sociais

Figura 3: Culturas Formativas e suas respectivas idades no continente Americano

Figura 4-: Localização das culturas ceramistas relacionadas à Fase Pocó-Açutuba

Figura 5 - Piracema na Cachoeira do Teotônio

Figura 6 - Transposição da Cachoeira do Teotônio

Figura 7 - Vista do sítio Santa Paula a partir do sitio Teotonio

Figura 8 - Exemplo de preenchimento dos sacos plásticos, com identificação de materiais

Figura 9- Exemplo de quadriculamento de $2 \mathrm{~m}^{2}$

Figura 10 - Perfil N da unidade N10001 E10003

Figura 11 - Perfil E da Unidade N10001 E10003

Figura 12 - Unidades escavadas em Fevereiro de 2013 paralisadas devido à chuva intensa

Figura 13 - Perfil S das Unidades N1003 E10003 e N10004 E10003

Figura 14 - Estrada de acesso à antiga Cachoeira do Teotônio

Figura 15- Barranco da estrada antes de ser exposto e retificado

Figura 16 - Acompanhamento do processo de limpeza do perfil com a pá mecânica

Figura 17 - Retificação do perfil exposto

Imagem 18 -Perfil alinhado ao grid já estabelecido do sítio

Imagem 19 - Atividades de limpeza e retificação do perfil

Figura 20 - Panorâmica dos perfis das unidade N10030 E9987 / N10045 E9987

/Perfil Leste da Linha E 9987

Figura 21 - Perfil N da Unidade N 10030 E9987

Figura 22 - Lente de carvões aglomerados, no quadrante de barbante

Figura 23 - Detalhe da lente de carvão

Figura 24 - Abertura de picadas na capoeira fechada

Figura 25 - Utilização do nível óptico para o alinhamento das tradagens

Figura 26 - Realização de sondagem em área de capoeira

Figura 27 - Realização de sondagem em área aberta de pasto

Figura 28 - Mapa do Sítio Teotônio

Figura 29-Visão geral da unidade N9920 E9940

Figura 30 - Nível 10-20 da unidade N9920 E9940

Figura 31 - Gráfico de incidência de vestígios arqueológicos da tradagemN100040 E9824

Figura 32 - Visão Geral da Unidade N10041 E9824

Figura 33 - Perfil W da unidade N10041 E9824

Figura 34 - Visão geral da unidade N10041 E9955

Figura 35 - Visão geral da unidade N10041 E9955

Figura 36 -Concentração cerâmica no nível $40-50 \mathrm{~cm}$

Figura 37 - Concentração cerâmica no nível $110 \mathrm{~cm}$

Figura 38 - Perfil S da unidade N10041 E9955

Figura 39 - Nivel 0-10cm da unidade N9947 E10005

Figura 40- Estrutura de argila queimada evidenciada, unidade na base dos $40 \mathrm{~cm}$ de profundidade

Figura 41 - Detalhe da estrutura de argila 
Figura 42 - Unidade N9947 E10005 finda, com a estrutura escavada

Figura 43 - Nivel superficial, base da estrada de acesso a antiga cachoeira do Teotônio

Figura 44 - Nível 20-30, pedestal para retirada da estrutura cerâmica

Figura 45 - Na base do nível 110-120, estrutura de combustão

Figura 46 - Perfil W da unidade N9882 E10022

Figura 47 -Coleta de amostras para palinologia na unidade N9882 E10022

Figura 48 - Coleta da coluna de sedimento na unidade N10041 E9955

Figura 49 : Tabela com as datações do sítio Cachoeira do Teotônio

Figura 50 - Tabela do resultado da triagem das unidades N10003 E10004/N10003 E10003

Figura 51 : Gráfico de Quantidade de matérias líticos nas unidades N10003 E10004 e N10003 e E10003 por categoria

Figura 52 - Incidência de material lítico e cerâmico, por nível, nas unidade N10003 E10004 e N10003 E10003

Figura 53 - Perfil Sul das unidade N10003 E10004 e N10003 E10003; entre o tracejado vermelho, a camada pré-cerâmica.

Figura 54 - Perfil Sul das unidades N10003E10003 / N10003 E10004

Figura 55 - Quantidade de líticos divididos por categorias (núcleos e tipos de lascas) por matéria-prima.

Figura 56 -Vista geral da oficina lítica

Figura 57 -Vista geral da oficina lítica

Figura 58 - Tipo de lasca por matéria prima - Unidade N10003 E10003

Figura 59 - Quantidade de lascas bipolares e unipolares por nível estratigráfico unidadesN10003 E10003 e N10003 E10004

Figura 60 - Grafico da incidência de Sementes, sementes não carbonizadas, coquinhos e parênquimas por camadas naturais

Figura 61 - Fragmento decasa de fruto de palmeira não identificada $-90 \mathrm{~cm}$ de profundidade

Figura 62 -Parenquima de tubérculo $-110 \mathrm{~cm}$ de profundidade

Figura 63 - Dados químicos das amostras pedológicas do perfill Norte da unidade N100045E9987

Figura 64 - Tabela de triagem do material cerâmico da unidade N10041 E9955

Figura 65 - Gráfico e quantidade total de material cerâmico (azul) e paredes decoradas (vermelho) por nível estatigrafico na unidade N10041 E9955.

Figura 66 - Perfil S da unidade N10041 E9955

Figura 67 - Perfil Wda unidade N9882 E10022

Figura 68. Tabela do índice de lascas por nível da unidade N9882 E10022

Figura 69: Quantidade de Categorias do material lítico por nível - Unidade N9882 E10022

Figura 70: Variação da quantidade de lasca unipolares e bipolares por nível - Unidade N9882 E10022

Figura 71:Gráficos de tamanho de lascas e de tamanho de núcleos - Unidade N9882 E10022

Figura 72 - Mapas de dispersão de material lítico (Massangana) e de dispersão do material cerâmico no sítio Teotônio 


\section{1- INTRODUÇÃO.}

\subsection{Notas preliminares:}

É importante salientar, de antemão, que este trabalho insere-se em um projeto de esforço maior, o Projeto Alto Madeira. Coordenado e iniciado pelos professores Drs. Eduardo Neves e Fernando Almeida, o PALMA completa em 2015 sete anos de trabalhos contínuos, com inúmeros resultados positivos já publicados (Azeredo, 2010; Almeida, 2013, Mongeló, 2014, Kater, 2014, Mongeló\&Almeida, 2014) que trouxeram a tona importantes dados acerca da ocupação humana na bacia do Alto Rio Madeira.

O pano de fundo dessa dissertação é, sem dúvida, os trabalhos iniciais de Eurico Miller nos anos 1980. Ele foi o primeiro a atentar à existência de extensas e profundas camadas de solo antrópico em áreas adjacentes às cachoeiras de Santo Antônio e do Teotônio, contextos estes que não estavam relacionados com material cerâmico. Assim como Almeida, que ao voltar ao sítio Teotônio em 2011 estava disposto a retomar e refletir sobre os dados pioneiros de Miller, este trabalho buscou ser também uma revisão de um contexto já descrito, que no entanto possui ainda muitas lacunas, tanto na descrição dos ditos dados como nas formulações teóricas.

Em parte, espera-se que seja uma contribuição importante à arqueologia do Sudoeste da Amazônia, reafirmando algumas das proposições do arqueólogo gaúcho, e melhor delimitando as fronteiras culturais existentes dentro do sítio da Cachoeira do Teotônio. Entender o sítio como uma unidade cultural, por onde transcorreu mais de 6 mil anos de história foi um desafio, tanto nas atividades de campo como nas análises laboratoriais, em função da complexa estratigrafia do sitio Teotônio foi, desde o início, um dos elementos mais instigantes de todo o projeto. 
O sítio Teotônio, diferente de outras regiões da Amazônia, possui um continuo de ocupação humana que se estende por grande parte do Holoceno, e nos permite observar essa história de longa duração sob uma perspectiva nova no cenário da terras baixas. A possibilidade de entender como se deram os processos de mudança de sociedade caçadoras-coletoras pré-ceramistas para sociedade sedentárias/horticultoras só foi possível após a clara compreensão desses estratos dentro do sítio arqueológico, e foi a partir dessas observações que começou-se a debater as questões ligadas ao conceito de Formativo e de Revolução Neolítica no trópico brasileiro. Esse elemento é importante pois permite que façamos o exercício de realizar uma discussão acerca dos modelos teóricos que tem como base a fundamentação dos dados empíricos, questionamos a dicotomia caçador-coletor - ceramista/sedentário pois o contexto nos exige.

Sendo assim, espera-se que leitores compreendam que objetivo desta dissertação não encontra seu fim na desconstrução teórica de determinado modelo histórico, o exercício de compreender a totalidade dos processos sociais a partir de uma perspectiva que explique de fato as incongruências dos dados expostos se deu na medida em que não foi possível enxergar razão na explicação através dos tradicionais aportes. $\mathrm{O}$ estudo da raiz do conceito de Período Formativo, e a necessidade de expor seu afastamento do que foi definido como Revolução Neolítica, tornou-se uma exigência epistêmica, pois só expondo o processo de consolidação de tal perspectiva histórica que foi possível, através dos aportes do materialismo-dialético, compreender que há uma outra forma de entender os processos sociais que, no contexto arqueológico do sítio Teotônio, não parecem encaixar em nada.

$\mathrm{Na}$ Introdução, que segue abaixo, delinearemos uma rápida explanação acerca dos dados inicialmente levantados por Miller que caracterizam os contextos précerâmicos do Alto Rio Madeira, ponto de partida para o desenvolvimento da pesquisa. No capítulo 1, debateremos os conceitos de Período Formativo e Revolução Neolítica, modelos teóricos que Miller e tantos outros arqueólogos enxergaram como explicação 
para esses processos de mudança que ocorreram na América por volta do III Milênio. Nos capítulos 2 e 3, descreveremos as atividade de campo e de laboratório, apresentando os dados gerados nas duas atividades, e por fim, no capítulo 4, lançaremos luz a uma proposta de periodização histórica que compreenda as variantes perceptíveis nos contextos do Alto Madeira.

\subsection{A arqueologia do Alto Rio Madeira - do PRONAPA AO PALMA}

O Rio Madeira corta a porção sudoeste da floresta Amazônia, em um eixo sudoeste nordeste, desde Abunã até encontrar as longas várzeas do Rio Amazonas, em Itacoatiara. Se configura no maior afluente do Rio que nomeia a floresta. O maior afluente do maior rio da maior floresta tropical do mundo. Pudera, é formado do encontro de importantes drenagens fluviais que possuem suas raízes nos Andes, os rios Madre de Diós e Beni, que se encontram na cidade boliviana de Riberalta, e que na fronteira com o Brasil, de fronte a pequena vila ferroviária de Yata, encontra outro hidro-gigante, o Rio Mamoré, que também a partir dos Andes, adentra na floresta amazônica rasgando os campos alagados dos Llanos de Mojos.

A insistência na ênfase hidrográfica da região se justifica, não só pela grande quantidade dos corpos aquáticos, mas também pela importância histórica que as vias fluviais representaram enquanto elementos naturais de locomoção, subsistência e cosmologia. Por mais que a região do Alto Rio Madeira seja só mais um exemplo da grande diversidade e ecossistemas da floresta Amazônica, esta possui, tal qual, elementos que podem configurar a ela uma identidade única.

A arqueologia é um destes elementos. A especificidade da arqueologia na bacia do Alto Rio Madeira se dá, já de antemão, pela grande quantidade de conhecimento 
produzido na região ${ }^{1}$. Em (1978), no relatório realizado pelos arqueólogos Mario Simões e Fernanda Araújo-Costa em decorrência do Programa Nacional de Pesquisas Arqueológicas da Bacia Amazônica, foi feita uma listagem dos sítios arqueológicos do extinto território Federal de Rondônia (ao qual o Alto Rio Madeira pertence em toda sua extensão); os mesmos indicam a existência de 15 sítios arqueológicos, quase todos localizados na bacia do Guaporé, na fronteira com a Bolívia. No entanto, um pequeno parágrafo na introdução do texto deles nos permite uma reflexão quase que anacrônica:

\footnotetext{
"Infelizmente, essa unidade federativa vem recebendo pouca atenção dos arqueólogos profissionais. Com exceção dos achados ocasionais, feitos por amadores e curiosos, e a prospecção realizada pela etnóloga Etta BeckerDonner, do Museu de Viena, em 1954-56, ao longo da margem direita do rio Guaporé, só recentemente, com o Programa Nacional de Pesquisas Arqueológicas na Bacia Amazônica (PRONAPABA), teve ali início as pesquisas arqueológicas com os trabalhos de campo de Eurico TH. Miller, do Museu de Arqueologia do Rio Grande do Sul.”
}

O arqueólogo Eurico Th. Miller, citado ali por Simões e Araújo-Costa, fora incumbido pelo nascente PRONAPABA (este, filho direto do extinto Programa Nacional de Pesquisas Arqueológica - PRONAPA) de iniciar as pesquisas sistemáticas em Rondônia. O mesmo Mário Simões, em relatório de 1983, cinco anos depois, relata que Eurico Miller, em dois anos de intensos trabalhos de campo, identificou 72 sítios. Nas áreas por eles definidas como pertencentes à região do Alto rio Madeira, dentro do estado de Rondônia (Guajará, Jaci-Paraná, e Porto Velho), foram contabilizados 36 sítios

\footnotetext{
${ }^{1}$ Assertiva levantada quando comparada a região do Alto Rio Madeira com o restante do território nacional. Dada a imensidade geográfica de possibilidades de atuação da pesquisa acadêmica no século XX, e as dificuldades logísticas em se trabalhar na floresta amazônica, é de se espantar a quantidade de dados produzidos sobre este cenário, ainda que pairem enormes desafios perante a complexidade dos registros arqueológicos.
} 
arqueológicos. Um número considerável para a arqueologia anterior ao advento da resolução CONAMA, de 1986.

Ao longo das décadas de 1970 e 1980, Miller atuou quase que de forma solitária na região, inicialmente como arqueólogo do $\mathrm{MARSUL}^{2}$, depois trabalhando para o Governo do Território e finalmente, como consultor da ELETRONORTE, nas grandes obras desenvolvimentistas no estado de Rondônia. O quadro geral das pesquisas arqueológicas no Alto Rio Madeira, portanto, é fruto do trabalho inicial de Miller, que atuou de forma ininterrupta na região por mais de 30 anos, criando bases para entendimento da ocupação humana no sudoeste da Amazônia.

O Projeto Alto Madeira surgiu num hiato de duas grandes levas de pesquisas arqueológicas na região, como bem coloca Almeida (2011): “Quando João Aires e eu chegamos a Porto Velho em fevereiro de 2008 para iniciar os trabalhos de campo do Projeto Alto Madeira (PALMA) nem o pioneiro Miller estava mais lá. As empresas de arqueologia já rondavam, mas não estavam lá. Não havia ninguém.". Fernando Almeida e Eduardo Neves retomaram, depois de quase uma década sem atividades de pesquisa, a as atividades arqueológicas na região do Alto Rio Madeira; a questão principal para os dois era entender melhor a cerâmica da tradição Polícroma, sua relação com a família linguística Tupi e lançar luzes sobre o possível centro dispersor dessa cultura.

As datas mais antigas relacionadas à tradição Policroma, na forma do seu correlato regional, a fase Jatuarana, foram evidenciadas no sítio Teotônio, às margens da cachoeira homônima, por Eurico Miller, e giram por volta de 700 A.C. As poucas informações publicadas por ele, e o isolamento da data ante os contextos policromos na bacia amazônica contribuíram de forma significativa para que o sítio Teotônio fosse incluído na área de pesquisa de Fernando, que originalmente iria trabalhar apenas na bacia do rio Jamari.

\footnotetext{
${ }^{2}$ Museu Arqueológico do Rio Grande do Sul
} 
A etapa de escavação levada a cabo pelo PALMA em julho de 2011 no sítio Teotônio foi de grande importância para que Fernando compusesse a trama da cerâmica Polícroma na região, até mesmo questionando as datações de Miller. A escavação revelou, além da cerâmica pintada em preto e vermelho, uma estratigrafia complexa, profunda e intrigante, e em uma unidade de $1 \mathrm{~m}^{2}$ foi possível constatar a existência de mais de $1 \mathrm{~m}$ em profundidade de camada de terra preta antrópica sem a presença de cerâmica, mas com uma quantidade grande de lascas e núcleos de quartzo.

De certa forma, tanto Eduardo como Fernando sabiam da existência de camadas de Terras Pretas profundas e antigas, pois Miller já havia dissertado pouco a respeito, mas a fase Massangana, ainda que existente apenas nas páginas de papel de algumas revistas, ainda era uma incredulidade. Nesse clima de exaltação e dúvida (teríamos evidenciado um contexto pré-cerâmico à céu aberto na Amazônia, com indícios de sedentarização?), propusemos algumas questões que por fim, se concretizaram no projeto de mestrado apresentado ao programa.

Nesse sentido, este projeto de mestrado proposto em 2012 inicialmente tinha como objetivo geral elucidar a questão da Fase Massangana no alto rio Madeira, discutindo a relação da presença de Terra Preta e a inexistência de material cerâmico, de forma que se equalizasse os pressupostos teórico-metodológicos que definem o conceito de Período Formativo. O grande desafio da proposta era encontrar, no registro arqueológico, elementos que pudessem embasar a hipótese de que, de fato, ocorreu uma mudança nas relações de produção das sociedades pré-colombianas no sudoeste da Amazônia.

Com uma dose de humildade que talvez tenha crescido ao longo do ano, movimento natural, imagino eu, na medida em que se aproximam os prazos de entrega de relatórios, mantive os objetivos gerais; mas como plano de fundo para questões mais palatáveis e passíveis de serem respondidas no tempo que me é cabível. Assim, elenquei alguns pontos como objetivos específicos e que espero desenvolver na dissertação: 
- Entender a complexa estratigrafia do sítio Teotônio, tendo em mente os processos históricos que conformaram o contexto arqueológico;

- Caracterizar a indústria lítica dos contextos antigos e ceramistas;

- Entender a cronologia das ocupações ceramistas, buscando identificar um complexo ceramista antigo;

- Contribuir para o início da compreensão das formas de manejo ambiental, pensando não só a instrumentalização (lítico/cerâmica) como marcadores históricos de processos de mudança de economia.

A questão da transformação de sociedade caçadoras-coletoras em ceramistassedentárias é um problema que já havia sido levantado por Miller, epor isso grande parte desta introdução é dedicada à explanação do que o mesmo levantou para a região. O objetivo aqui é repensar suas hipóteses sobre esse processo a partir dos dados levantados, tendo o sítio Cachoeira do Teotônio como área piloto, uma vez que foi constatada a presença dos distintos contextos arqueológicos no mesmo.

\section{$\underline{1.3 \text { Eurico Miller e os dados iniciais da arqueologia rondoniense }}$}

Nas primeiras pesquisas na área do alto rio Madeira e afluentes (principalmente o Rio Jamari), Eurico Miller (1992, et alii, 92) estabeleceu um quadro cronológico baseado principalmente na análise tipológica dos artefatos obtidos, com datações que chegam a 8000 AP. De acordo com a divisão geográfica feita por ele, duas áreas pesquisadas pelo arqueólogo são relevantes para esta pesquisa, a bacia do Alto Madeira e a bacia do médioalto Jamari. São importantes por serem as duas regiões onde foram evidenciados contextos pré-ceramistas antigos. 


\section{Região do Alto Madeira}

Na calha do alto Rio Madeira, Miller definiu a existência de 8 fases arqueológicas, a partir de uma perspectiva histórico-culturalista, típica no PRONAPABA, projeto ao qual o arqueólogo estava inserido então. A ocupação na calha deste rio, segundo ele, teria iniciado por volta de 12000 AP, no final do Pleistoceno, com o Complexo Cultural Periquitos, conjunto artefatual relacionado a um sítio nas proximidades de Porto Velho. Segundo o mesmo, "mergulhadores de garimpo teriam trombado com esqueletos de paleoíndios, dos quais trouxeram a tona somente alguns crânios" (Miller, 1992).

Segundo o mesmo, foi coletado uma quantidade pequena de evidências materiais, somando-se 39 o número de instrumentos líticos. Caracterizada por uma indústria de lascas e lâminas finas e pequenas, de matéria-prima de quartzo e sílex. Poucos núcleos foram evidenciados, no entanto, ele afirma que a técnica mais empregada de lascamento era a percussão direta dura, sendo também identificadas algumas evidências de microlascamentos sob pressão.

Essa fase descrita por Miller ainda carece de maiores estudos para que se possa tomar como dado. O levantamento de Bueno (2013), por exemplo, sobre sítios do início do Holoceno no território brasileiro não relaciona estas evidências do Alto Madeira. De fato, as publicações de Miller, não são claras, pouca descrição dos contextos e nenhuma foto dos artefatos ou crânios.

No entanto, é preciso creditar a Miller a primeira inferência sobre a existência de ocupações pré-ceramistas na calha do Alto Madeira. Na tabela publicada em relatório de 1978, o arqueólogo lista os sítios à céu-aberto com evidências de material arqueológico ligados ao "Complexo Girau", que juntamente com o Complexo Periquitos, compõe o cenário de ocupações Holocênicas na região. O Complexo Girau,". O complexo Girau um contexto de indícios de materiais arqueológicos em líticos lascados, em solo não antropizadoe presente em cinco sítios na calha do Rio Madeira e um no rio Mamoré: o 
sítio Teotônio, Pederneira 2, Paredão, Girau, Periquitos e Ribeirão. Para Miller, os dois complexos são a representação material de modos de vida caçadores-coletores de indígenas e paleo-indígenas que habitaram a calha deste Rio.

Miller se debruçou apenas uma vez sobre estes sítios (com exceção do Teotônio), e além dele, nenhum outro arqueólogo voltou a esses locais, portanto, a única fonte de dados que há é o relatório do "Inventário Arqueológico da bacia e sub-bacias do Rio Madeira", de 1987, revisado pela arqueóloga Solange Caldarelli. Não se sabe ao certo se Miller chegou a datar algum dos contextos relacionados ao complexo Girau, possivelmente não, pois em artigo de 1992 (Miller, 1992) ele categoricamente o define apenas como uma “camada de ocupação do Holoceno Médio", entre 6000 e 9000 anos. O material lítico é caracterizado por lascas de quartzo, sílex e rochas graníticas, “obtidas por percussão dura direta, com poucas evidências de retoque por pressão". Ainda é possível observar a presença de algumas lâminas, e núcleos esgotados que poderiam representar raspadores.

Nota-se, que dos sítios com a presença do complexo Girau levantados por Miller, todos se encontram na margem direita do Rio Madeira, e nas proximidades das grandes cachoeiras; tal característica é inclusive ressaltada por Simões (1987).

Não é possível afirmar que a existência destas ocupações pré-ceramicas estaejam relacionadas apenas à margem direita do rio. No entanto, sítios de grande porte, como o Santa Paula, Morrinhos e Morro dos Macacos, que encontram-se na margem esquerda do Rio Madeira, foram escavados por mais de uma equipe (Almeida, 2013, Suze, 2011) e não foram evidenciados ocupações pré-ceramistas. (Anexo 1). $\mathrm{O}$ acesso à beirada do rio é mais fácil através da margem direita do Madeira, que é servida por estradas vicinais que saem da BR-364, logo, essa porção do rio foi arqueologicamente mais explorada do que a outra margem, o que pode eventualmente pode ter um impacto na precisão e na quantidade de dados levantados. As camadas profundas com artefatos líticos podem estar na margem esquerda, e nós (arqueólogos) ainda não os encontramos. 


\section{Rio Jamari}

Miller realizou pesquisas nos anos 1980 na área afetada pela construção da Usina Hidrelétrica de Samuel, no Rio Jamari, e até a pesquisa de doutorado de Fernando Almeida (2013), foi o único arqueólogo a trabalhar nesta bacia. Além de ser conhecido como um dos primeiros estudos de licenciamento ambiental no Brasil, as pesquisas de Miller foram importantes pela caracterização inicial de contextos pré-coloniais nessa bacia que também compõe o Alto Madeira.

De forma mais substanciosa, se comparada às publicações anteriores, Miller define uma série de ocupações, sistematizadas na forma de fases e tradições, para a bacia do Jamari que vão de 8000 AP até o presente. Em sua primeira publicação (1992) sobre a área de pesquisa, Miller identifica a presença de 2 fases pré-cerâmicas, além de um conjunto material relacionado à "transição" do Formativo. Aqui, dar-se-á mais atenção às elucidações de Miller sobre os vestígios pré-cerâmicos, uma vez que entende-se que já há um razoável acúmulo de informações sobre os contextos cerâmicos. (Almeida 2013, Zimpel, 2009, Suze 2014).

Dos 101 sítios levantados na área de impacto da construção da Usina, o arqueólogo pôde relacionar dezesseis com a presença de pré-cerâmicos, sete destes com as fases líticas Itapipoca e Pacatuba, e doze com a Fase Massangana. Uma diferença básica entre os três conjuntos artefatuais é em relação ao contexto em que foram encontrados. A Fase Massangana é composta por uma indústria lítica presente em solo antrópico, a Terra Preta; e as fases Pacatuba e Itapipoca, não. Sendo o advento da Terra Preta um evento relativamente recente em relação ao Holoceno (Arroyo Kalim-, 2010), Miller a considera a mais recente.

A Fase Itapipoca encontra-se presente nos sítios RO-PV-47; RO-PV-49 e ROPV 74, localizados no médio Jamari, nas margens direitas de cachoeiras homônimas, 
caracteriza-se por ser uma indústria de "lascas de sílex, quartzo e rochas cristalinas de pequenas a grandes, finas a grossas, com e sem retoque". Além disso, segundo ele, foram evidenciados núcleos esgotados, raspadores laterais e circulares e percutores de diversos tamanhos. O arqueólogo não apresenta dados acerca dos formatos dos sítios, tampouco disposição dos vestígios, que se encontram sob pacotes enterrados, entre 32 e $56 \mathrm{~cm}$ de profundidade. Para ele (Miller et. all, 1992), a fase Itapipoca seria mais antiga pois encontra-se em contextos sem continuidade estratigráfica, são camadas de material lítico enterrados em áreas de platô, junto à cachoeiras. Ele obteve quatro datações entre 8.320 e 6.970 AP.

A Fase Pacatuba, como já mencionado, foi evidenciada junto à "sítios-habitação" da Fase Jamari (cerâmica). Miller definiu essa fase a partir de dois sítios, Lima (RO-PV32) e Cachoeirinha (RO-PV-52), situados no médio rio Jamari, e segundo ele, “estratigraficamente é esperada uma cronologia entre 2000 e 5000 anos a.P.”. Posteriormente, foram identificados mais quatro sítios (RO-PV 27, RO-PV-35. RO-PV48 e RO-PV 76), que obtiveram datas de 6.090 e 5.210 AP (Miller et.all, 1992). O material lítico se caracteriza por uma quantidade pequena de lascas de quartzo, e em menor quantidade em sílex e outras rochas cristalinas, segundo ele, foram ainda evidenciados núcleos lascados e percutores.

Sabe-se que, apesar do alagamento da área do rio Jamari, quando da construção da Usina de Samuel, alguns desses sítios não foram totalmente submersos. No projeto inicial, apresentado ao programa, um dos objetivos era revisitar alguns desses sítios, de modo que se pudesse refinar a cronologia proposta por Miller. No entanto, as maiores partes dos mesmos ainda encontram-se guardados em propriedade da ELETRONORTE, e a burocracia dificultou o acesso. Além disso, a facilidade logística do sitio Teotônio nos fez dar prioridade para o mesmo. 


\subsection{Miller e o Formativo - A fase Massangana}

Eurico Miller foi de fato um dos poucos arqueólogos brasileiros a se preocupar especificamente com o processo de transformação de sociedade caçadoras -coletoras em ceramistas, muito, ao nosso ver, devido ao contexto por ele evidenciado nas regiões do Alto Madeira, nos campos alagados do Guaporé e nas chapadas das bordas do sudoeste da Amazônia. Apesar das poucas publicações, é possível esboçar algumas linhas gerais que definem o raciocínio de Miller, acerca das transformações socioeconômicas na floresta tropical.

Para ele, a distinção entre grupos caçadores-coletores para grupos agricultores não se dá apenas pela presença ou não da cerâmica, mas também pela Terra Preta de Índio (TPI), solo antropogênico com grande quantidade de nutrientes e matérias orgânicas, resultado de anos de uso intensivo do solo, relacionados a características sedentárias e à prática da agricultura. Embora hoje em dia essa seja uma teoria amplamente aceita pela comunidade acadêmica (Neves, et al. 2003), Miller (1987) percebeu que alguns sítios possuíam descontinuidade estratigráfica de Terra Preta, ou seja, em sítios como Teotônio (RO- JP-01), Porto Seguro (RO-JP-03) (e diversos outros no rio Jamari), existem camadas de Terra Preta enterradas que aparecem na estratigrafia entre 1,3 e 2,1 m de profundidade (Miller, 1992), com grande presença de artefatos líticos, como lascas, raspadores, pedrasbigornas, pequenos pilões e mãos de pilão "toscas" (sic). Na bacia do rio Jamari, Miller definiu esse contexto como Fase Massangana.

Tais camadas de Terra Preta enterradas Miller acredita estarem relacionadas a um processo de mudança de "comportamento de assentamento semi-permanente", no qual o solo antropogênico seria indicativo de uma agricultura incipiente baseada no sistema de derrubada e queima (coivara). Essa transição teria se dado entre 3850 AP e 3140 AP (Miller, 1992 et all.), período de diminuição de umidade, e consequentemente, diminuição dos recursos alimentícios. 
Em artigo de 1999, Miller apresenta três etapas para o Formativo do sudoeste amazônico, a primeira, em que os homens passaram da condição de simples predador para predador-produtor, ou, em suas palavras, de caçador-coletor para agricultor incipiente. Para ele, um dos resultados desse processo é a disseminação intencional de plantas que se tornaram marcadores biológicos de ocupação de território, como o Urucuri, palmeira que não é endêmica na região. A segunda etapa ocorre com o aparecimento da cerâmica, em distintos momentos em diferentes lugares, como no trecho encachoeirado do rio Madeira, no Mamoré, no Ji-Paraná (Miller, 2009). No sítio Teotônio, para ele, essa etapa é muito visível com o surgimento no registro da cerâmica Jatuarana. A terceira etapa corresponde ao sedentarismo efetivo, a passagem "completa da índole nômade do caçador-coletor para a índole sedentária da agricultura", depois de superada as condicionantes ambientais, físicas e bióticas".

É interessante frisar, que diferente dos tradicionais aportes para a definição de fases utilizado por Miller, a Fase Massangana não representa especificamente um conjunto de artefatos, ela representa um processo. Ou seja, não são apenas determinados tipos de lascas ou tipos de cerâmica que compõem a Fase Massangana, ela é definida por um conjunto de fatores que remetem tanto a elementos clássicos de ocupações caçadorascoletoras, como de atributos visivelmente identificados com formas de organização sedentárias.

Portanto, mesmo que não seja tão explícito assim na sua redação, a definição de Miller para a Fase Massangana se dá pela existência indireta e, portanto, inferida, dos seguintes contextos: sedentarização (inferida pela presença de terra preta), agricultura(inferida pela presença de polidos e machados) e da ausência de cerâmica (material lítico).Diz ele: "Esse evento cultural primeira etapa do Formativo, com base na agricultura está representado pela Tradição Massangana, com refugo cultural précerâmico embutido em solos de terra preta antropogênica" 
A agricultura, nessa hipótese, não estaria ainda completamente desenvolvida, sendo classificada como subsistente, e complementar às atividades de caça, pesca e coleta, de forma que não teria ainda se tornada a atividade principal na produção econômica. Miller atenta para a importância da palmeira de Bacuri (Attaleaphalerata) nesse processo, que são encontradas hoje em dia em praticamente todos os sítios arqueológicos de Rondônia, neste processo, como um elemento natural energético de recurso abundante, e um indicador importante de subsistência. Do seu ponto de vista, as sociedades précabralinas no sudoeste amazônico não atingiram a completude da terceira etapa do Formativo, foi uma etapa "alcançada e não transposta", faz parte de um processo interrompido de desenvolvimento.

O processo de sedentarização, somado ao início do cultivo de plantas e o aparecimento da cerâmica são vistos por Miller como elementos indivisíveis do mesmo processo, este materializado na Fase Massangana, uma "tropicalização" do termo Formativo, ou ainda, uma repaginação do Neolítico de Childe (1954). Portanto, estudar esse processo de transformação de sociedade caçadoras-coletoras em sociedades sedentárias-ceramistas necessita necessariamente de uma reflexão profunda sobre conceitos históricos e linhas de raciocínio que embasam não só a teoria de Miller, mas que são coniventes com o senso comum reproduzido, de forma ampla pela arqueologia brasileira. 


\begin{tabular}{|c|c|c|c|c|c|}
\hline & \multicolumn{3}{|c|}{ Alto Madeira } & \multicolumn{2}{|c|}{ Jamari } \\
\hline & $\begin{array}{l}\text { Complexo. } \\
\text { Periquitos }\end{array}$ & Complexo. Girau & F. Massangana & Fase Itapipoca & Fase Pacatuba \\
\hline Sítios & $\begin{array}{l}\text { Periquitos (RO- } \\
\text { GM-12) }\end{array}$ & $\begin{array}{l}\text { Teotônio } \quad \text { (RO-JP-01); } \\
\text { Pederneira } 2 \text { (RO-GM-3); } \\
\text { Paredão (RO-GM-6); Girau } \\
\text { (RO-JP-6), Ribeirão (RO- } \\
\text { GM-5); Periquitos (RO- } \\
\text { GM-12) }\end{array}$ & $\begin{array}{l}\text { RO-PV- 11A; } \\
\text { RO-PV-35; } \\
\text { RO-PV-48; } \\
\text { RO-PV-27 }\end{array}$ & $\begin{array}{l}\text { Monte Cristo (RO- } \\
\text { PV-29); Itapipoca } \\
(\text { RO-PV-59) }\end{array}$ & $\begin{array}{l}\text { Lima (RO-PV-32); } \\
\text { Cachoeirinha (RO-PV- } \\
\text { 52) }\end{array}$ \\
\hline Datas & $12000-15000$ A.P. ${ }^{3}$ & 6000-9000 A.P. ${ }^{4}$ & 3850 AP e 3140 AP & 8.320 e $6.970 \mathrm{AP}$ & 6.090 a $5.210 \mathrm{AP}$ \\
\hline $\begin{array}{l}\text { Indústria } \\
\text { Lítica }\end{array}$ & $\begin{array}{l}\text { Lascas e lâminas } \\
\text { finas e pequenas de } \\
\text { quartzo e sílex }\end{array}$ & $\begin{array}{c}\text { Lascas de quartzo e sílex e } \\
\text { rochas graníticas, obtidas } \\
\text { por percussão direta }\end{array}$ & $\begin{array}{l}\text { Micro lascas de quartzo e } \\
\text { sílex, nódulos de hematita } \\
\text { corantes, bolas de barro } \\
\text { cozido, mós, mãos de } \\
\text { pilão }\end{array}$ & 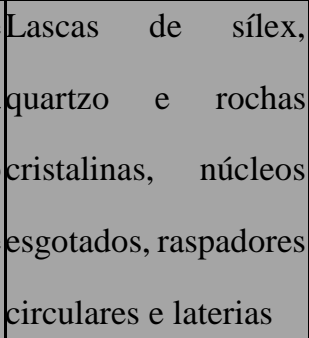 & $s \mid \begin{array}{l}\text { Pequenas lascas de } \\
\text { quartzo e poucas de sílex, } \\
\text { núcleos lascados e } \\
\text { percutores }\end{array}$ \\
\hline
\end{tabular}

Figura 1 - Tabela das ocupações pré-ceramistas na bacia do Alto Rio Madeira e Rio Jamari (Miller, 1987; 1992) 


\section{2- A Revolução Neolítica e o Período Formativo: O que são e o que significam}

Ford (1965) foi o principal responsável pela introdução do termo Formativo no linguajar da arqueologia das Terras Baixas Americanas (Lima 2008, Marcos 2003, Neves, 2006). Segundo ele "Formative" has come into use to denote what in the Old World would be called early or initial Neolithic. Neolithic would be a perfectly good name, but Americanists have been very reluctant to commit themselves to any terminology that would seem to imply Old World relationships".

Entende-se que o a definição do Período Formativo, tal qual consagrada por Ford, e aceita, em linhas gerais, pelos arqueólogos sul-americanos, possui uma relação na sua origem, com o conceito de Revolução Neolítica de Gordon Childe. O arqueólogo australiano foi um dos mais próceres pesquisadores da primeira metade do século XX que se preocupou em estabelecer bases comparativas entre períodos históricos, e delineou esse processo de transformação de sociedades caçadoras-coletoras em ceramistas-sedentárias. Quando fala-se em Período Formativo, é inegável a comparação com o semelhante movimento ocorrido no Velho Mundo.

A diferenciação entre Revolução Neolítica e Período Formativo é necessária para demonstrar que os dois não representam o mesmo movimento social, não correspondem ao mesmo processo de mudança pois suas concepções enquanto conceitos são distintas. Para poder questionar os valores imbuídos na formulação do que se definiu como Formativo, é preciso distanciá-lo da formulação de Childe, e possui, como veremos, uma proposta diferente.

Iniciaremos esse capítulo explanando acerca da concepção materialista de história de Gordon Childe, que o permitiu ver um processo revolucionário em um modo de produção pré-capitalista. O objetivo, aqui, é demonstrar as profundas diferenças epistemológicas entre as definições de "Formativo" e "Neolítico", mostrando que as mesmas possuem caminhos de construção ideológica conceitualmente distintos. Ao definir o que, para os pesquisadores atuais se configura como Período Formativo, irá se 
fazer uma breve retomada acerca dos recentes estudos do dito período nos contextos de florestas tropicais.

\subsection{A Revolução Neolítica e o materialismo-histórico na Arqueologia}

A revolução neolítica, conceito definido por Childe, está carregada por determinadas concepções de história que necessitam ser destrinchadas para que se possa usar o termo de acordo com sua definição elementar. Muito já se falou das interpretações de Childe acerca dos processos de mudanças sócio-econômicos que ocorreram na Europa e no oriente próximo por volta do quinto milênio antes de cristo (McGuire, 2006): a definição de Revolução Neolítica e Revolução Urbana, a contribuição do australiano ao debate ecológico, etc. No entanto, entende-se que é na raiz epistemológica do pensamento marxista de Childe que está a chave para a compreensão mais segura de suas assertivas teóricas, e isso nos possibilitará encontrar uma chave explicativa par ao contexto sulamericano (McGuire, 2015).

Marx e Engels (1970) ao cunharam uma concepção materialista da história, desenvolveram uma nova forma de compreender os períodos históricos. Balibar (1995), comentando Marx, diz, acertadamente, que a grande inovação do alemão se deu no campo epistemológico, o desenvolver de um método novo de aplicabilidade científica que permite a análise da história dos homens com um víeis total (Marx, 2008; Lowy, 2007). O Materialismo Histórico "tem como constante objeto a própria história, da qual ele inaugura o conhecimento científico, e não oferece em parte alguma o conceito adequado dessa história, refletido por ele mesmo", é a dialética da produção de conhecimento, pois é fruto de seu tempo e de suas condições materiais. Isto significa, a produção de conhecimento científico histórico se encontra calcada na perspectiva de compreensão dos principais questionamento da sociedade atual, criando elos e conexões históricas que permitam ao narrador explicitar o desenvolvimento das relações históricas entre os homens e entre estes e a natureza.

O materialismo histórico, aplicado na ciência do tempo, é uma teoria substantiva da sociedade, ou seja, um mecanismo que permite discutir e definir conceitos gerais a fim de compreender a sociedade como totalidade concreta, com todos os elementos que a compõe: economia, cultura, trabalho, política, etc. 
O principal elemento que caracteriza o materialismo-histórico é a dialética. Não há uma definição simples, concreta e direta para o conceito de dialética, e nem é o intuito aqui nos determos no assunto, mas é um dos eixos principais de diferenciação da noção marxista de história para as outras epistemologias, e isso se reflete de forma substanciosa na diferença entre os conceitos de "Formativo" e de "Neolítico". A dialética é um modo diferente de observação de fenômenos concretos da sociedade, muita das vezes não acessível através da lógica formal. Novack (1969) assim a define:

A dialética se baseia num ponto de vista completamente diferente e tem uma visão distinta da realidade e suas formas variantes. È a lógica do movimento, da evolução, da mudança. A realidade está demasiadamente cheia de contradições, demasiadamente fugidia, por demais mutável para amarrá-la numa fórmula ou conjunto de fórmulas. Cada fase particular da realidade constrói suas próprias leis, seus sistema de categorias peculiares, com as que compartilham de outras fases.

É a noção de dialética que permite ao cientista uma percepção não estável das relações sociais, uma relação não necessariamente de causa-efeito entre os atores históricos, uma concepção de cultura e ambiente anti-estática. McGuire (1999) pontua a importância da dialética no estudo da cultura material a partir da possibilidade de realização de uma abordagem interpretativa do estudo do mundo social que não é puramente empírica, tampouco especulativa. Para ele, é uma das ferramentas úteis para a equalização do caráter subjuntivo da interpretação arqueológica e dos dados concretos, objetivos. $\mathrm{Na}$ arqueologia, lida-se tanto com elementos como a produção de dados factível, possíveis de obter verdades objetivas (Rowlands 1984), como também é necessário passar por questões intuitivas de interpretação.

O materialismo histórico-dialético na arqueologia apresenta-se como o método mais conveniente às explicações dos fenômenos humanos, não se deixando cair no mito do positivismo cego, tampouco na tentação do relativismo total. Para os marxistas, (Kohl, 1981) o debate entre objetividade e subjetividade é infrutífero, pois não possui fim em si mesmo, e somente a dialética apresenta-se como um meio inicial de ultrapassar tal dicotomia. A tradição marxista na arqueologia assume que há um mundo real além dos sentidos e do subconsciente, e que é possível obter conhecimento empírico através da observação científica dos fenômenos humanos. Os fenômenos humanos possuem, mesmo 
os presentes no campo ideológico, uma concretude real. A ideologia do racismo, hoje em dia por exemplo, é visível em diversos aspectos da nossa sociedade, quando observamos que são os negros que ocupam as maiores porcentagens nas camadas de miséria no Brasil, ou que são os que em maior número são assassinados pela polícia militar, estamos observando a concretude de uma ideologia, que possui, dialeticamente, um pé no campo subjetivo, e um pé no campo real. O materialismo-dialético lida com a possibilidade da observação de determinados elementos concretos da sociedade que perpetuam-se no tempo por serem generalizantes, sem deixar de serem explicativos, como classe social, propriedade, trabalho, contradição e revolução.

Para Rowlands (1984), muitas das dificuldades encontradas no paradigma que aparentemente opõe correntes majoritárias na arqueologia (in one hand, the past is an object without a subject, on the other it is a subject without object), se dá pela ineficiência de métodos em "estudar regularidades e correlações da vida social". O materialismohistórico trata-se justamente disso, um engenhoso mecanismo de análise que permite a percepção de elementos regulares nos processos sociais históricos, o que por sua vez dá sentido aos eventos passados, através da formulação de categorias analíticas (formação social, modo de produção, etc).

A capacidade operacional dos elementos definidos pelo método dialético é tamanha que permite ao cientista a contextualização dos inúmeros fenômenos humanos ao longo do tempo, estabelecendo uma linha coerente de sucessão de fatos. Como diz Bate (1987, pp. 128), o objetivo dos marxistas com o método dialético é o "exame da realidade social e formulação teórica explícita das relações existentes entre as regularidades formalizadas nas categorias de formação social, manifestação social, etc". É através da identificação dos nexos recíprocos dos aspectos da realidade que se constrói a visão de uma sociedade composta por elementos palatáveis colocados em categorias, vislumbrando, assim uma totalidade concreta.

A importância destes elementos analíticos, que são categorias não abstratas, está melhor explicitado pelo próprio Marx no Prefácio à Contribuição à Crítica da Economia Política (1970). Para ele, a dinâmica da vida social dos homens, que possui aspectos concretos, está relacionada intimamente à relações de produção, estas, por sua vez, calcadas na noção de trabalho. O que ele chama de "ser social", a essência das ações humanas, é o resultado do conjunto estrutural sistêmico que define a sociedade, como a 
economia, a política, a religião etc. As relações de produção, portanto, são resultado destes aspectos sistêmicos, que por sua vez são modificados dialeticamente pelos homens. A essa relação entre homens e sistema produtivo, Marx chamou de modo de produção.

O conceito de trabalho, nesse sistema, é essencial para a compreensão da definição de modo de produção, pois é no trabalho que o homem se configura como ser social. Para Wolf (1982), trabalho é o resultado da relação dialética do homem se sobrepondo à natureza: "a forma com que estão organizados socialmente rege a forma com que enfrentam e transformam a natureza, e por sua vez, a natureza assim transformada, afeta a arquitetura dos vínculos sociais humanos". A natureza estabelece uma condição básica para a existência do gênero homo, que é explicitada pela relação dialética de Wolf, essa condição, na base de sua explicação, e o que o marxismo chama de trabalho, "a condição geral do metabolismo entre homem e natureza". O homem, consciente de sua ação, por sobrevivência ou não, realiza atividades que lhe permitem continuar sobrevivendo enquanto espécie, ele está realizando trabalho, produzindo ferramentas de rocha lascada, produzindo cerâmica, pescando, coletando, etc.

Sendo assim, trabalho é a unidade básica de análise do materialismo-dialético, pois é o elemento analítico basal para destrinchar as formas de organizações sóciopolíticas. Trabalho é um conceito que corresponde a uma pluralidade, sempre, é a descrição de atividades realizadas em conjunto por um corpo da sociedade, para Marx, o trabalho é sempre social.

O conjunto de formas de trabalho, sociedade e natureza são o que caracterizam as forças produtivas. Estas, resultado da interação homem-ferramenta-natureza, se modificam de forma dialética ao longo do tempo, pela "contradição da vida material, pelo conflito existente entre as forças produtivas sociais e as relações de produção". Ao afirmar isso, Marx quer dizer que a sociedade se explica em si, de acordo com seu tempo histórico, e que as mudanças ocorridas nas formas de organização social ao longo dos milênios são compreensíveis por fatores existentes nos estamentos sócio-econômico-políticos que caracterizam os modos de produção. $\mathrm{Na}$ análise total do materialismo dialético, os processos de mudança, ou revoluções, possuem lógica pela contradição inerente da dialética da relação do trabalho com as forças produtivas. 
A grande inovação de Marx em relação a análise do desenvolvimento social, foi colocar essa análise dos modos de produção em seus tempos históricos. Ou seja, a realidade das relações sociais possui uma explicação em si, através da sua dialética, e nas formas pretéritas que a configuram como tal. Quando ele diz que é o "ser social que determina a sua consciência", ao definir a existência do ser enquanto político, Marx tem em mente que as forças produtivas, exemplificação concreta das relações de produção, são constituídas pelo desenvolvimento histórico dos homens, sobre e com a natureza. A grande exemplificação deste paradigma encontra-se nos debate com Proudhon (2003), que segundo Marx, questiona acertadamente a noção de propriedade, mas é incapaz, diz ele, de dar um sentido histórico a esse elemento crucial no capitalismo. Para o primeiro, a propriedade privada possui explicação nos estamentos da sociedade moderna burguesa, para Marx, a raiz da propriedade privada estava "nas relações de propriedade como um todo, não só em sua expressão legal”, ele a explica através da análise de categorias econômicas expressivas de relações históricas de produção.

Os modos de produção, por exemplo, são sim explicados pela dinâmica dos organismos que o compõe, mas a raiz de sua existência está no desenvolvimento histórico destes organismos. O capitalismo, modo de produção atual, possui uma dicotomia classista básica que é inerente a sua explicação, a existência de um campo majoritário de trabalhadores e um campo minoritário de burgueses. A classe burguesa, enquanto conceito, pode ser explicada pelos aspectos que a caracterizam hoje em dia, no entanto, sabemos que a burguesia se desenvolveu como fruto das contradições históricas do capitalismo mercantil dos séculos XV-XVII (Marx, 2008), assim como o proletariado. Não existem classes no capitalismo porque o capitalismo assim o exige, existe porque houve um caminho de desenvolvimento de determinados elementos (estes, os analíticos) que configuraram de tal maneira o sistema sócio-político-econômico.

Para os arqueólogos, a percepção materialista-histórica de Marx configura-se como um paradigma inovador, dando sentido às formas das relações sociais em seu contexto histórico. O próprio Childe (Rowlands 1984, Lamberg-Karlowsky, 2009) nunca escondeu que o intuito de estudar as formas de organização pré-históricas estava calcado no seu interesse de explicar o desenvolvimento do capitalismo no coração da Europa. Através do método dialético, as narrativas históricas são construídas com objetivos claros de influenciar as formas sociais dos que as produzem, uma vez que estes possuem consciência temporal. Dessa forma, diz Marx, é impossível que qualquer análise de 
modos de produção datados (históricos) não tenha um alto caráter de práxis, o materialismo-dialético não é alienado.

Esse ponto é importante para entender as formulações de Childe. Para Marx, o desenvolvimento das forças produtivas ao longo do tempo possui um encadeamento lógico, porém não linear. Como bem coloca Hobsbawn (2012) a "teoria geral do materialismo histórico só requer que haja uma sucessão de modos de produção, porém, não necessariamente esses ou aqueles modos particulares, e talvez, nem mesmo em uma ordem predeterminada.". Mas que tipo de sucessão é essa? Sob quais aspectos se dão as mudanças?

São estas as principais perguntas que Marx e Engels se colocam, e se dispõe a responder através da ótica do materialismo dialético. O grande desafio, para eles dois, era explicar a sociedade como uma totalidade concreta, mediando o entendimento dos nexos recíprocos entre os aspectos da realidade que se pretende refletir nas categorias de formação econômico-social, modo-de-vida, cultura, etc (Wolf, 1982)

Marx (1964, 1977) crê que existem, ao longo do tempo, diferentes estágios de desenvolvimento das forças produtivas, estes, são diferenciados a partir da perspectiva da divisão social do trabalho, ou seja, as formas com que os seres humanos se organizam em relação à produção (esta, um elemento inexorável de sua existência). Para ele, os mais diversos tipos de divisão social do trabalho se dão, de forma elementar, pela configuração de diferentes formas de propriedade: sobre a terra, sobre a mão-de-obra, sobre os recursos, etc.

Clarificando a equação, trabalho é definido como a reprodução da vida social dos homens, a forma como concretizam sua existência na prática diária, como buscar alimentos, respirar, sentir, etc. Estas ações são realizadas pelos homens, sobre a natureza, modificando-a ou não, mas necessariamente apropriando-se dela. Como ele pode perceber, propriedade é a apropriação da natureza pelos homens, que se dá através do trabalho: "a relação do trabalhador com as condições objetivas de seu trabalho é uma relação de propriedade, é a unidade natural do trabalho" (Marx, 1987). Sendo assim, no desenvolvimento da história humana, houveram diferentes formas de propriedade, que significaram diferentes tipos de divisão social do trabalho. Social, diz ele, pois o homem 
é um "animal social", não trabalha como um "Robinson Crusoé", isolado numa ilha (Wolf, 1982), necessariamente interage e coopera com seus pares.

Essa é base da teoria marxista para o desenvolvimento das forças produtivas, a partir da análise destes conceitos é possível estabelecer uma linha histórica coerente e explicativa. Como diz Bate (1987), a periodização histórica é uma característica inevitável ao materialismo-dialético, afinal há elementos que são comuns a qualquer desenvolvimento histórico de qualquer sociedade, e mesmo assim, são visíveis as diferenças. O marxismo trata, em sua essência, de identificar os elementos comuns, definindo unidades classificatórias de qualidades diferentes, relacionadas ao processos sociais. Que unidades são essas? Propriedade, divisão social do trabalho, relações sociais de produção, etc., regularidades fundamentais e gerais que regem a totalidade dos fenômenos da vida cotidiana.

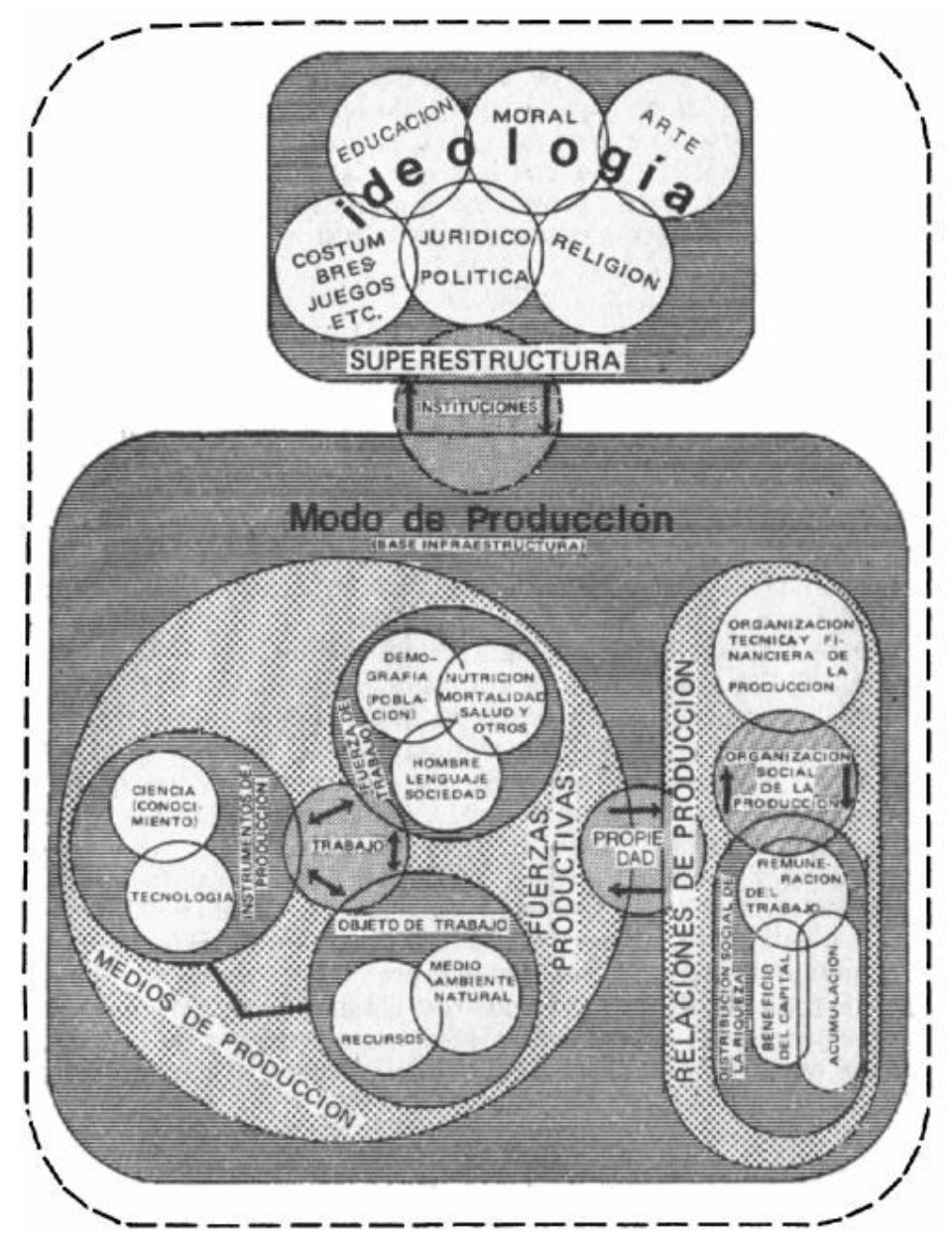

Figura 2. Desenho esquemático do entendimento materialista-dialético das dinâmicas sociais. Lumbreras (1981) 
A Origem, da Propriedade Privada e do Estado foi a primeira tentativa de Engels (2012) de aplicar o método dialético ao desenvolvimento do gênero humano. Muitos (Lowie, 1937; Redfield, 1953) se utilizaram desta obra para atacar as teorias marxistas por terem uma visão simplória da evolução humana e o desenvolvimento cultural das sociedades, de fato, é a partir da leitura cega desse texto de Engels que Stalin publicou, em 1938, Dialetical and Historical Materialism. O ditador sustentou uma visão histórica fixa e unilienar, estabelecendo uma sucessão obrigatória de modos-de-produção, estanques, abdicando do método dialético para a explicação dos fenômenos históricos. Por razões políticas bastante claras, essa acabou se tornando a linha geral da produção acadêmica marxista que orbitava Moscou, em diversos campos do conhecimento, o desastre epistemológico stalinista no campo das humanas foi tão grande que até hoje o marxismo é visto com nariz torto por muitos acadêmicos (Lowy, 2007)

Esses mal-entendidos sobre a aplicação do método dialético na arqueologia são importantes de serem explicitados pois tem relação direta com a produção de conhecimento marxista durante o século XX, e em grande parte, sobre a arqueologia. A exceção da arqueologia soviética do pós anos 40 (Childe, 1942), a concepção marxista da história nunca advogou a favor de uma narrativa unilinear, não dialética. Spprigs (1984) enfatizou a necessidade de não se dogmatizar os escritos de Marx, e que a visão crítica na verdade é comum entre os estudiosos dos campos das humanidade que são próximos ao marxismo. Concorda-se com sua visão historiográfica de que os trabalhos de arqueólogos clássicos, como Godelier (1977) centram-se em uma perspectiva de história dinâmica. Giddens explicita esse ponto de vista em uma interessante dica: "Don't look at functions social practices fulfil, look for the contradictions thei embody!'”(1979 apud Spriggs, 1984). Para eles, contradição e conflito provêem a base inicial para o entendimento das dinâmicas da sociedade, como dominação, legitimação, e principalmente, mudanças;

A produção acadêmica de Childe está inserida nesse campo de idéias, sem dúvida, ao equilibrar as teorias de Marx e Engels, e aplicá-las ao contexto do Danúbio e do Oriente Próximo, o australiano desenvolveu narrativas que são muito próximas do desejado por seus predecessores. Quando Childe fala em mudança, revolução e modo de produção, ele está falando sob a ótica de um militante marxista acadêmico, imbuído, de todas as maneiras, da perspectiva materialista dialética. 
Isso é importante para retomarmos o conceito de Revolução Neolítica de G. Childe, seu aspecto inovador está calcado em décadas de desenvolvimento teórico, o que necessita com que aprofundemos a análise dos elementos conceituados por ele, por isso o preâmbulo sobre o método materialista-dialético.

Childe acreditava realmente no caráter transformador do estudo da história, em 1946, ele definiu a arqueologia como:

"possivel de prover conhecimento prático e utilitário, no curso das relações humanas que iludem os historiadores literários. De fato,vou sugerir (Childe) que a arqueologia é um elemento indispensável nas ciências sócias, pois o dado arqueológico pode e deve gerar a base confiável exigida para o estudo das dinâmicas de mudanças sócias, e só ela pode promover evidências nas mudanças de longa-duração na vida das sociedades” .

A declaração do australiano deixa claro duas coisas. Primeiro, de que sua perspectiva científica estava calcada fortemente na práxis, a produção de conhecimento do passado estava a serviço da transformação social do mundo atual. Na tarefa de explicitação científica dos eventos passados, e aí está o segundo ponto, os marxistas só poderiam alcançar a caracterização dos "elementos comuns à sociedade" através da arqueologia, único ramo da ciência moderna plausível de atingir a realidade concreta das sociedades ágrafas. É sabido do interesse que Childe tinha pelos escritos de Engels, tanto que impulsionou uma reedição de A História da Família, da Propriedade Privada e do Estado, em 1943, e tal como nós, observou os problemas científicos das descrições do alemão sobre os período da "barbárie" e "selvageria". Ninguém havia ainda aplicado o materialismo-dialético ao estudo da pré-história, e nisso Childe inovou.

A maturidade científica de Childe, sobre os processos de transformação social se deu, ao nosso entender, em Man Makes Himself (1945), foi onde ele sistematizou e definiu os conceitos de Revolução Neolítica e Revolução Urbana. O nome da publicação já é um grande marcador epistemológico, é o retrato de um marxismo egocêntrico sem ser negativo, coloca o homem como ser social primordial de sua existência, agente de seu tempo, tornando a "vontade" como eixo catalisador de suas escolhas pelas formas de organização em sociedade.

O centro na análise de Childe é o trabalho, a forma com que os homens se sobrepõe a natureza, fabricando ferramentas, instrumentalizando a produção. Aliás, é importante 
frisar que ele já vinha, a algum tempo, publicando textos mais profundos sobre o papel do desenvolvimento das ferramentas e seu papel no desenrolar das forças produtivas. Para ele, "archaeologists can follow the story of tools, men have changed not only their tools but also the whole way in which they got their living (their economy), and consequently the way in which society was organized for co-operation". (Childe, 1944).

Porque dar tanta ênfase para as ferramentas? Pois são elas, segundo Marx, que melhor representam, de forma material, a dialética das forças produtivas, do motor histórico das sociedades. Diferente dos braços, das pernas, dos dedos, instrumentos são socialmente construídos, pensados e materializados para a realização de atividades de TRABALHO. Essa categoria, como já vimos, é a base para a compreensão da complexa relação que envolve homem e natureza.

A noção de trabalho tão latente em suas publicações, e é tão grande a ênfase que ele dá aos desdobramentos da análise específica das ferramentas que, para traçar um panorama geral da história européia, ele não foi a campo, e sim, pesquisou em acervos e coleções de museus. Salvo raras exceções, como os trabalhos comandados por ele em Skara Brae, textos clássicos como A pré-história do Danúbio e O Nascimento da Civilização Europeia foram obras preconizadas em diversos museus do mundo. Trabalhando apenas com coleções, ou seja, com ferramentas, Childe pôde concentrar seu estudo na teoria geral do desenvolvimento humano (pré-histórico) calcado unicamente na classificação marxista de trabalho.

Do mesmo modo que ele pôde identificar regularidades nesses sistemas, a partir da manutenção de traços tecnológicos nas ferramentas da pré-história europeia, Childe aprofundou as análises sobre os processos de mudança destas sociedades. Vimos já, que no materialismo-dialético, as mudanças profundas nas formas de apropriação são processos inerentes a qualquer modo de produção e a qualquer status-quo, pois as contradições necessárias para as mudanças encontram-se em si mesmo.

As ferramentas, sob a perspectiva marxista, são a materialidade do ponto nevrálgico das relações sociais, que é a noção trabalho. Ao buscar uma linha coerente, histórica, nas diversas formas de organização das sociedades passadas, Childe encontrou elementos que pudessem ser comparáveis, apesar das particularidades das realidades dos diversos contextos; mas que dessem um certo sentido à formação das sociedade 
contemporâneas. No livro History (1947), é possível ver, resumidamente, como se coloca o papel das ferramentas na construção de narrativas históricas:

\begin{abstract}
Now the simplest aspect of historical order is the progressive extention of humanity's control over external nature by the invention and discovery of more efficient tools and processes. Marx and Engels were the first to remark that this technological development is the foundation for the whole history conditioning and limiting all other human activities. Thus Marxism asserts that all constitutions, laws, religions and all other so-called spiritual results of man's historical activity are in the long run determined by the material forces of production-tools and machines-together with, of course, natural resources and the skills to operate them. Thus the Materialist Conception offers a clue for the analysis of the data of history and opens up the prospect of reducing its phenomena to an easily comprehensible order.
\end{abstract}

O que Childe fez foi, portanto, achar, no registro arqueológico, elementos que dessem coerência histórica a um processo que, sabemos, foi inexorável em algumas partes do mundo, de sociedades caçadoras-coletoras, grupos populacionais se transformaram em estados poli-classistas. Como explicar isso? Para ele, o método materialista era a chave de explicação.

Ao prezar pela busca de recorrências nas relações sociais, Childe centrou sua análise nos elementos que o marxismo entende como eixos de apoio ao entendimento da totalidade das forças sociais concretas, resumidas, nas categorias de modos-de-produção. Modos de produção, como mostramos, não são fases estanques da trajetória evolutiva humana, são constantemente modificados e possuem as mais diversas contradições no ceio de suas definições, e, é através dessas contradições que ocorrem mudanças bruscas. Para Childe, uma das principais mudanças da história dos homens foi a Revolução Neolítica, um processo revolucionário que modificou profundamente as formas de relação entre homem e natureza.

A revolução neolítica de Childe é vista como sui generis pois foge um pouco à escrita das tradicionais explicações de momentos revolucionários no marxismo. $\mathrm{O}$ Neolítico, de fato, foi uma mudança brusca, mas a seu ver, possuiu momentos intensos e momentos de constância econômica, é o que explica a divisão entre Revolução Agrícola e Revolução Urbana. É um conjunto de processos que acontecera, segunda ele, a partir de um encadeamento de fatores sucessórios e conseguintes, resultado de mudanças tecnológicas, ideológicas, econômicas e políticas. 
Dois elementos são importantes de se colocar, ao mostrar as explicações de Childe. O primeiro é em relação aos contextos. Foi a partir do arcabouço teórico do marxismo que ele construiu uma narrativa histórica, mas suas conclusões estão calcadas, basicamente, nos registros concretos oriundos das pesquisas arqueológicas. Mesmo que houvesse, e certamente havia, uma pressão ideológica dos clássicos do marxismo que definiram teoricamente o que é um processo revolucionário (Marx, 1970), a noção de levas pulsatórias de desenvolvimento das forças produtivas, decorrendo umas das outras, é a interpretação lógica do arqueólogo sobre as escavações de Nínive, Skara Brae, e outros tantos sítios "neolíticos" que estavam sendo avo de pesquisa no momento. Assim, é importante frisar que foi a partir dos contextos que ele propôs a primeira ideia de Revolução Neolítica, um processo de avanço das forças produtivas ligado ao aumento da população, inovação tecnológica e controle da produção de alimentos. Peace (1988) resume bem a concepção do australiano:

"For Childe, techno-economic innovations (metallurgy, the wheel, food production, etc.) led to revolutionary technological and social changes; these he identified as the Neolithic and Urban Revolutions. In Man Makes Himself, Childe(1936) explicitly stated that "one of the purposes of this book is to suggest that, viewed from an impersonal scientific point, history may still justify the belief in progress."”

Não há como negar a inovação epistemológica com a concepção do conceito de Revolução Neolítica de Childe, no entanto, é inegável também o caráter negativo da sua noção de "progresso". Patterson (2005) chega a ver, inclusive, aspectos do liberalismo econômico no grau de importância que o australiano dá para o desenvolvimento das técnicas agrícolas, e do papel que tais inovações teriam tido ao proporcionar um novo modo de relação social entre homens e coisas. Apesar de válida, a crítica parece um pouco tanto desmensurada, pois Childe enxerga a domesticação e a agricultura como efeitos catalisadores, de fato, mas quem negaria que o processo, na região do Crescente Fértil, não foi tão impactante como ele diz? A questão é, talvez, pensar essas inovações mais como representações de determinados movimentos regionais, do que exemplos para toda a história do desenvolvimento humano.

A agricultura, portanto, colocada em um pedestal de transformação tecnológica por Childe, permitiu, segundo ele, que os homens adquirissem o controle total sobre a 
produção de alimentos, é o suprassumo da sobreposição do gênero sobre a natureza. Dialeticamente, diz ele, o controle da produção alimentar implicou no planejamento contínuo dos bens agriculturáveis, e a necessidade do estabelecimento de novas dinâmicas de relações sociais que incluíssem o caráter preditivo de obtenção de recursos, quase que uma tomada de consciência das próprias capacidades, por parte dos homens. Resumidamente, para ele, o aumento da quantidade de alimentos (e aí inclui-se a domesticação de animais, tanto para auxílio na agricultura, como para alimentação direta) e mais fontes de proteína implicam em aumento de população, expansão das áreas de plantação, o que levou a um processo contínuo de estratificação social, ligado muito aos elementos de prestígio e das práticas guerreiras, mas também, segundo ele, à necessidade preditiva da base alimentar e do papel chave da dominação ideológica por parte do controle das religiões totêmicas.

Essa é, em linhas gerais a concepção de Revolução Neolítica de Childe. A materialidade desse processo se dá, em primeiro lugar, pelas evidências dos primeiros gêneros alimentares domesticados, pelo aparecimento da cerâmica, e pela estabilidade dos assentamentos, que anteriormente compostos por grupos caçadores-coletores, eram sazonais.

O segundo ponto, que gostaríamos de frisar, é a importância que Childe dá aos homens como agentes primordiais desse processo. Se na Revolução Neolítica, o desencadear da domesticação de alimentos desemboca quase que invariavelmente em sociedades semi-estratificadas e sedentárias, a Revolução Urbana, momento posterior, é fruto das capacidades de escolhas dos homens. A Revolução Urbana, para Childe, é um processo indissociável da Revolução Neolítica, é o reflexo do avanço das forças produtivas, com o adendo do elemento "escolha".

Para ele (Lamberg-Karlowsky, 2009), as vilas Neolíticas eram exemplos de sociedades livres e igualitárias, com o mínimo de controle social e total harmonia em relação aos meios de produção, que sofreram com a drástica mudança a partir da constituição dos centros urbanos. No processo definido como Revolução Urbana, a especialização de determinados setores da sociedade implicaram no início da desigualdade social, a partir de emergência da um sistema interdependente entre artesãos e produtores de comida, possibilitando o crescimento do sistema de trocas que começou 
a funcionar sob a lógica da mais-valia, da transformação do valor de uso em valor de troca (Marx, 1970).

A utilização da mais-valia como um elemento mensurável e dimensionável, representando um valor não abstrato foi uma grande mudança, do ponto de vista de Childe, é o que Engels chamou de Acumulação Primitiva de Capital. No Processo de Revolução Urbana, isso se dá em conjunto com a aglomeração populacional em centros proto-urbanos, constituídos a partir de grupos que não necessitavam sustentar-se através do trabalho agrícola de forma direta. O primeiro impacto, portanto, é a mudança na relação entre homem e natureza, a partir da segmentação da sociedade, segundo Childe coesa até então, em relação ao acesso aos recursos e ao controle das forças produtivas. $\mathrm{O}$ fim da auto-sustentabilidade das comunidades Neolíticas quer dizer, na verdade, o início da perda de controle dos camponeses de sua força de trabalho para aqueles setores urbanos que a começaram a explorar lhes.

Para ele, todo esse processo é intencional, não necessariamente consciente, mas totalmente no controle do homem. A "práxis" na construção da narrativa histórica do neolítico de Childe encontra-se juntamente nessa assertiva. A Acumulação Primitiva de Capital, o nascimento das classes sociais, do estado, da propriedade privada, todos esses elementos que nos acompanham até hoje na moderna sociedade capitalista precisam, em sua gênese estar ligados a possibilidade de escolha dos seres humanos. Do ponto de vista revolucionário, é aí que os "homens fazem-se por si mesmo", é a partir da capacidade de escolha, este um aspecto racional, que os homens podem ser o únicos agentes da mudança de sua realidade social, a luta contra o capitalismo atual é um exemplo.

Essa não é uma leitura comum dos textos de Gordon Childe, pois em geral, a arqueologia, e principalmente a americana do pós-guerra, vê a concepção do australiano muito calcada em uma lógica evolucional-funcionalista, criticando-o sob as mesmas consignas que Lewis Morgan (1985). A comparação é desmedida, Childe estabeleceu um debate antagônico profícuo com os antropólogos culturalistas norte-americanos, como Morgan, Boas e Steward principalmente em relação à definição de culturas arqueológicas e seus correlatos materiais (McGuire, 2015). 
Acredita-se que o preconceito em geral que existe com o materialismo-dialético, e principalmente no contexto do "mcarthismo", nos anos 1950, na academia norteamericana, contribuiu para que a leitura dos textos do australiano sempre sejam vistas sob uma perspectiva evolucionista muito forte, em alguns momentos, inclusive, aproximando-o de Leslie White e Julian Steward (1948). A fé no progresso das forças produtivas é um elemento constante nas dissertações sobre os processos de mudança, talvez seja um aspecto visceral do autor, que acreditava fortemente na capacidade humana de modificação da realidade social, mas de modo algum, a sua compreensão de evolução social, ou a de qualquer outro marxista, pode ser comparada com a perspectiva culturalevolucionista dos autores citados, com o que ficou materializado, por exemplo em Handbook of South American Indians(1948).

Muito pelo contrário, o materialismo-dialético de Childe vai de encontro, inclusive, à percepção de grupo cultural, proposto por esta corrente antropológica. A dialética, como ferramenta de análise, não é capaz de conceber uma visão de cultura determinada unicamente por fatores materiais, ela é resultado de um processo histórico, que tanto é influenciada como influencia. Ele se opôs, assim, à perspectiva clássica de divisão cultural cronológica dos histórico-culturalistas, constatação clara diante das leituras das cartas trocada com Braidwood e Kroeber (apud Peace, 1989). Childe refuta o boasianismo, mas ao mesmo tempo, epistemologicamente, se coloca distante das correntes antropológicas vigentes do pós II Guerra, fortemente influenciadas pela perspectiva evolucionista social. A construção deste "terceiro-campo" fica evidente com as publicações de History e Archaeology and Antrhopology $(1946,1947)$ no final dos anos 1940 e início dos anos 1950.

A aceitação das idéias de Childe na academia norte-americana é um bom termômetro para nós pensarmos nos desdobramentos que o conceito de Revolução Neolítica tomou em toda a arqueologia americana após a disseminação de seus textos. A despeito do forte preconceito, que por sinal, ele sempre fora um grande denunciante, o marxismo nos Estados Unidos, e o contexto da Guerra Fria (McGuire1992), são constantes, até hoje Sem dúvida, o marxismo, como epistemologia da práxis, "sempre foi

\footnotetext{
${ }^{5}$ O Mcarthismo foi o nome comum dado a uma série de medidas políticas tomadas pelo governo dos Estados Unidos durante os primeiros anos da Guerra Fria (1945-1960) que visava conter a influência do marxismo no campo político, econômico e cultural. Sob a justificativa de "manter a paz" em território americano, foram presos e/ou demitidos inúmeros professores, atores, cineastas e lideranças sindicais. O senado Joseph McCarthy foi a pessoa publica que melhor personificou os intentos do governo norte-americano ligado às práticas anti-comunistas domesticas.
} 
atacado com persistência pois sempre foi identificado com movimentos políticos que ameaçavam o statua-quo, com regimes considerados subsercivos, perigosos $\mathrm{e}$ ameaçadores" (Hobsbawn, 2012).

No nosso entender, a conjuntura política do pós Guerra, no ocidente, criou um ambiente que dificultou a análise mais substanciosa, em grande medida, das obras de Gordon Childe, e especificamente, sobre o conceito de Revolução Neolítica. Esse movimento foi recorrente com diversos outros autores marxistas durante a segunda metade do século XX, como Maurice Dobe (1946), Godelier (1977) e Meilassoux (1972). Suas profundas análises dos campos dos quais eram especialistas foram criticadas de forma muito superficial pela academia, tendo tido pouca influência nos meios científicos fora da Europa.

Seria muito superficial, no entanto, dizer que a Guerra Fria explicaria os limites da capacidade de influência dos materialismo-dialético de Childe pelo resto do mundo, no entanto, há de se observar que a geopolítica mundial contribuiu significantemente, e não só nesse caso, para o entendimento "enviesado" da concepção de Revolução Neolítica. Não é preciso ser um marxista convicto para analisar a produção do australiano, mas é necessário pensá-la sobre a lógica dialética, e isso foi feito por poucos pesquisadores.

O preâmbulo acerca do método materialista-dialético de seriação histórica se faz necessário para que se compreenda melhor o que Childe quis dizer ao propor a Revolução Neolítica e a Revolução Urbana. Sua epistemologia está calcada profundamente na noção da práxis, para ele, era extremamente necessário a construção de uma narrativa histórica que compreendesse o início das desigualdades e das dominação da propriedade privada.

Essa processo de transmissão de idéias e teorias é importante para traçarmos a trajetória do conceito de Revolução Neolítica e, de que forma, ela acabou virando, na América o Período Formativo, a partir dos anos 1950. De que forma, portanto, se consolidou a definição de um processo histórico que possui uma raiz profunda no materialismo dialético, levada a cabo por arqueólogos histórico-culturalistas? 


\section{$\underline{\text { 2.2 O Período Formativo - Definicões na América do Norte }}$}

Nos anos 1950, a arqueologia Norte Americana vivia sob um processo de consolidação da perspectiva histórico-culturalista. "The mid-1930's through the early $1950 \mathrm{~s}$ were, in several respects, the heyday of the culture history paradigm" (Lyman, R.L.; O’brien, M. \& Dunnel, R 1997). Epistemologicamente, representou uma continuidade da visão de cultura que havia se iniciado, na antropologia norte-americana, com Franz Boas, e da contribuição dos estudos dos arqueólogos europeus do início do século, que trouxeram consigo a perspectiva taxonômica de classificação de sociedades.

O culturalismo-histórico é uma corrente que possui um paradigma sofisticado de entendimento da cultura material como reflexo direto de aspectos substantivos das sociedades, estes, percebíveis através da aplicação de métodos de seriação. É uma tentativa de compreensão das diferenças culturais dos povos (pré-históricos ou não) a partir das diferenças materiais dos objetos que estes produziram.

A seriação aparece, portanto, como um mecanismo metodológico para identificar recorrências na cultura material, agrupando em "unidades artificiais" (Ford 1969 que reflitam, de alguma forma, normas ou idéias culturais das pessoas que as produziram. Sobre o método, Ford diz: "Type is nothing more than material that exhibits a high degree of similarity in the features that reflect the influence of ideas prevailing in the ancient cultures (...) types were extensionally derived from the continuously changing culture train know as pottery"

O próprio Gordon Childe teve, durante um período de sua produção acadêmica, nos anos de 1930, uma perspectiva muito próxima do histórico-culturalismo Em linhas gerais, ele comparou diversas coleções cerâmicas, estabelecendo fronteiras temporais e espaciais, criando assim, um cenário cronológico da ocupação da Europa. Na América do Norte, não foi diferente, expoentes dessa vertente teórico-metodológica, como Kidder, Kroeber (1930) e Ford estabeleceram bases de explicação da dispersão de "culturas arqueológicas" no continente norte-americano, a partir de uma visão de cultura unilinear.

Trigger (1999) bem resumiu ao dizer, a respeito do histórico-culturalismo na América do Norte, que: 
"Focos e aspectos eram definidos através da listagem de tipos de artefatos para cada componente e pela verificação de quantos tipos distintos os componentes tinham em comum. Esse procedimento tinha correspondência pela concepção histórica particularista defendida por Boas, concepção segundo a qual as culturas eram vistas não como sistemas interligados, mas como coleções de traços que vinham a combinar-se em conseqüência de acidentes históricos”

A construção de tipologias com artefatos arqueológicos não é uma invenção dos norte-americanos. Vale-se dizer que essa perspectiva taxionômica provém de uma tradição científica que remonta aos princípios da constituição da arqueologia como ciência, na Europa do século XIX. A dicotomia entre "idades da pedra”, estabelecida, de forma mais substanciosa, pelos arqueólogos nórdicos é um tanto quanto evidente, na medida em que se compara os distintos materiais arqueológicos. Nessa perspectiva classificatória, calcada unicamente na complexidade dos artefatos, Trigger vê uma lógica evolucionista ligada à tradição Iluminista do século XVIII, para ele, a compreensão da "evolução da sociedade europeia desde o início da Idade da Pedra só despertava interesse em quem já estava predisposto a aceitar a evolução cultural como um tópico digno de consideração", e essa perspectiva a respeito da natureza humana só poderia terse dado a partir das ideias nascidas na Ilustração.

Quando os arqueólogos do século XIX separaram, em campos evolutivos distintos, a idade da Pedra Lascada, a Idade da Pedra Polida e tantos outros estamentos, estavam criando uma tradição de periodização da pré-história calcada na divisão concreta da materialidade, tanto a partir de aspectos sincrônicos em relação ao tempo, mas também em relação às características morfológicas dos artefatos. É nessa relação entre tempo (era) e ferramenta que se calca a produção de conhecimento científico moderno da arqueologia, em linhas gerais, quanto mais complexo é o instrumento, maior é a complexidade das sociedades dos que os produziram, e mais recente ele o é, por uma questão de lógica formal. Se complexifica as sociedades (elemento materializado na complexificação de suas ferramentas), na medida em que o tempo avança.

O histórico-culturalismo sem dúvida refinou, tanto em relação à teoria, como em relação à produção de dados, essa metodologia de construção de narrativas históricas. A perspectiva de atrelar conjuntos artefatuais à identificação de regularidades culturais, trouxe à superfície as divisões etapistas dos dinamarqueses, que dantes pairavam como 
uma abstração de cientistas. $\mathrm{O}$ estabelecimento de territórios culturais, tanto horizontalmente (espaço) como verticalmente (tempo), deu nome, endereço e história para os conjuntos artefatuais.

A isso, somam-se os estudos dos antropólogos norte americanos, como Franz Boas, que na virada do século, difundiram a perspectiva de que conjuntos culturais eram identificáveis através de recorrências na linguagem, na raça e na cultura material. No entanto, o desenvolvimento histórico dessas amálgamas culturais (ou raça, como ele diria) não é necessariamente unilinear, pois a seu ver (de Boas), estas mantém relativa independência. A perspectiva de estudar as culturas de forma independente teve uma forte influência nos arqueólogos, que a partir dos anos 1920, intentaram formular quadros crono-tipológicos, definindo culturas. (Boas, 1928), por exemplo, foi um dos alunos de Boas que produziu sob essa perspectiva.

Das contribuições da tradição Boasiana aos estudos arqueológicos, destacam-se duas principais, que são importantes para o estudo aqui. A sua recusa por uma história evolucionista, dando ênfase aos aspectos únicos das sociedades, popularizou o conceito de cultura etnográfica como unidade básica de estudo, isso se refletiu no estabelecimento, na arqueologia, de pesquisas focadas e especializadas em determinadas "culturas arqueológicas", estabelecendo-se cronologias à unidades culturais concretizadas nos objetos materiais. A essa perspectiva de história independente das sociedades, Boas construiu outro elemento teórico que é muito significativo aos arqueólogos, em relação aos processos de mudança. Para ele, a principal causa de mudança cultural está, uma vez que as sociedades se desenvolvem de forma independente, na difusão cultural. Esse ponto será retomado, mais a frente, quando tratarmos dos aspectos gerais da conceituação do período Formativo.

Mesmo haja inúmeros pontos de contato entre o culturalismo-histórico norteamericano e o europeu, é importante ressaltar que há um desenvolvimento particular da antropologia cultural no Novo Mundo, pois foi um dos elementos que distinguiu a produção científica americana durante boa parte do século XX. E o conceito de Formativo é, também, um fruto dessa história de aproximações e afastamentos epistemológicos entre os campos do conhecimento dos dois lados do oceano. 
Nunca se estudou a fundo a influência de Childe na arqueologia norte-americana, no entanto, analisando as obras dispostas para nós (Kroeber, 1993, Kidder 1926), ele, e os arqueólogos europeus em geral começaram a ser citados com certa frequiência, apenas após a II Guerra Mundial (McGuire, 2015; Patterson, 2003; Smith, 2009). A arqueologia americana, dominada pelos estado-unidenses, traçou um caminho um tanto quanto distinto e que, paradoxalmente, levou ao mesmo lugar. A concepção do Formativo é mais ou menos reflexo disso.

Para se ter ideia deste processo, um dos expoentes e mais característicos dos arqueólogos ligados ao histórico-culturalismo, Alfred Kidder, lançou, em 1926, uma grande síntese da ocupação pré-histórica do oeste dos Estados Unidos, chamada "An Introduction to the Study of Southwestern Archaeology". Este livro é considerado a primeira grande síntese da arqueologia norte-americana, uma pérola da exposição da metodologia de seriação cerâmica. No ano seguinte, Childe publicou a primeira edição de "The Dawn of European Civilization", seu primeiro ensaio sobre arqueologia. Epistemologicamente, os dois livros possuem a mesma linha de raciocínio, e o mesmo objetivo: caracterizar grandes áreas geográficas a partir do estudo da seriação dos artefatos, estabelecendo cronologias básicas e assim, criando um mosaico de "culturas" no tempo e no espaço.

Kidder provavelmente, neste ponto da vida, nunca havia se comunicado com Childe, e possivelmente nunca haviam ter ouvido um falar do outro, no entanto, a comparação é uma elucidação de o quão próximo era, em mundos acadêmicos com tradições aparentemente tão distintas, o conceito de cultura. Sendo assim, por mais que se tracem barreiras teóricas entre os arqueólogos do lado de cá do Atlântico e os do Velho Mundo, elementos nos mostram que comunhão de determinados traços acadêmicos é clarividente.

Antes fosse um caso isolado o exemplo citado, mas o culturalismo-histórico permaneceu como corrente programática na Europa de forma consistente até os anos 1960, mesmo com a reviravolta epistemológica posterior de Childe, que aproximou-se do marxismo. O culturalismo-histórico desenvolveu-se como pano de fundo teórico consolidado tanto no Velho, como no Novo Mundo, por quase meio século, e deixou um legado considerável na historiografia arqueológica, a ponto de estarmos, até hoje, saudavelmente discutindo as assertivas desenvolvidas então. 
Embora as modernas correntes da antropologia refuguem consistentemente essa perspectiva de definição do termo "cultura", acredita-se que, no campo no conhecimento científico da arqueologia, o legado do histórico-culturalismo ainda é grande. No entanto, não percebemos isso de forma negativa, pelo contrário, só reforça o caráter inovador destes arqueólogos que, de fragmentos de rochas e vasos, agarraram-se às metodologias dispostas, inovando na medida do possível, e construindo narrativas históricas. É tão emaranhado e intrínseco na literatura arqueológica alguns elementos oriundos da arqueologia da primeira metade do século XX, que alguns deles são dados como cânones dogmáticos, constatações e afirmações que percorreram as décadas e passaram por turbulentas revoluções na academia de maneira sólida.

O conceito de Período Formativo é um desses exemplos. Ele é fruto desse complexo jogo de profusão acadêmica anglo-americana, uma amálgama da tradição antropológica norte-americana, e do materialismo-dialético de Childe. Representa um conceito explicativo oriundo da análise de um instigante processo histórico, que foi percebível em diversos contextos no mundo, e que, nas Américas, teve sua definição proposta no anos 1950, e, pelo menos no Brasil, pouco foi debatida.

A introdução ao cenário da arqueologia norte-americana se fez necessária na medida em que é preciso entender que conceitos, categorias explanatórias, devem ser analisados como elementos de seu tempo, fruto de uma geração de conhecimento, e pertencente a uma tradição intelectual. O culturalismo-histórico representa o conjunto de idéias preponderante na academia norte-americana nos anos 1950, do qual a definição do Formativo apareceu, e aos poucos, foi consolidada.

Apesar da grande influência Boasiana, como já foi dito, desde pelo menos os anos de 1940, os arqueólogos norte-americanos que desenvolviam trabalhos sistemáticos em diversas partes da América, começaram a enxergar recorrências nos contextos arqueológicos. Além dos quadros regionais, que eram formados, com a disposição sincrônica e diacrônica das culturas, sínteses arqueológicas foram sendo produzidas na medida em que se iam conhecendo estes novos contextos arqueológicos que possuíam características semelhantes e lugares distintos das Américas.

A arqueologia, nos Estados Unidos, sempre estivera alocada, no meio acadêmico, como um dos campos da Antropologia, e os arqueólogos, dos anos 1920 e 1930 viveram 
esse embate teórico. No entanto, o registro arqueológico, meio por excelência de análise da ciência homônima, impõe determinadas capacidades de interpretação que impossibilita devaneios teóricos tão pouco palatáveis. Diferente da etnologia, a interpretação da ciência arqueológica, e em especial na época decorrida, é fruto da sistematização dos dados levantados em campo, e por mais que haja liberdades para construção de narrativas históricas e perspectivas inovadoras, o registro arqueológico é o que nos traz à tona à realidade concreta.

Entende-se que, com o crescimento das pesquisas arqueológicas na América, liderado pelos norte-americanos, criou uma profusão de dados que gerou, ao longo da primeira metade do século $\mathrm{XX}$, um afastamento quase que natural da perspectiva boasiana de cultura. A partir da seriação do material arqueológico e da construção de cronologias longas de ocupação, que geraram, de acordo com a interpretação de vários arqueólogos, a formatação de estágios sucessivos de desenvolvimento, trabalhos de grande fôlego foram produzidos com o objetivo de interpretar a observação de elementos comuns a diferentes contextos.

Aparentemente complexa, a questão colocada resume-se aos exemplos citados anteriormente. Trabalhos como o de Kidder nos EUA (1928) geraram uma base de dados enormes para cenários geográficos extensos. As mudanças ocorridas nas culturas, estas unidades monolíticas, eram explicadas através, ou do evolucionismo linear de determinados centros, ou do difusionismo de sociedades mais complexas.

Arqueólogos construíram periodizações de caráter evolucionista em toda a norteamérica. Termos como "estágios culturais" tornaram-se uma chave metodológica para explicar o desenvolvimento inegável da cultura material de sociedades pré-históricas, epistemologicamente, juntando o particularismo de Boas e a visão sistêmica de Malinowsky .No Sudoeste dos Estados Unidos, por exemplo, Kidder (1928) dividiu as ocupações pré-históricas em quatro estágios culturais: Basket Maker, Pós-Basket Maker, Pré-Puelo e Pueblo, sociedades estas que produziram inovações, como a cerâmica e a agricultura, e que daí teriam se propagado para outras partes da América do Norte. Trigger (2006) mostra que essa linha de raciocínio teve impacto na construção de cronologias também no meio-oeste norte-americano (McKern, 1945) e no sudeste dos Estados Unidos, quando James Ford e Gordon Willey (1941) definiram cinco estágios de 
desenvolvimento para as populações pré-cabralinas, entre eles, por exemplo, o Arcaico, que representaria as culturas caçadores-coletoras de Powerty Point.

O evolucionismo social como corrente teórica teve, portanto, implicações generalizadas na arqueologia americana da metade do século XX. A perspectiva geral destes acadêmicos era de que as sociedades humanas possuíam a possibilidade de evoluírem, de acordo com a melhor adaptação ao meio ambiente, garantindo assim a sobrevivência e propagação da sua população, inovando tecnologicamente, melhorando cada vez mais as técnicas de obtenção de recurso. Por mais que estes arqueólogos como Ford, Kroeber ou Kidder, não propagassem nem reivindicassem uma perspectiva darwinista social para suas pesquisas, existem elementos que são intrínsecos na sua produção acadêmica, e que possuem razão de serem, pelo desenvolvimento histórico das ciências humanas.

A chamada corrente histórico-culturalista, portanto, pode ser rotulada como evolucionista? Essa pergunta é importante, pois é aqui que se encontra a raiz do termo Formativo. Para Trigger, a linha de raciocínio sobre a capacidade dos arqueólogos histórico-culturalistas de dividirem a sociedade baseada na sofisticação tecnológica remonta a Montelius:

"Tal como antes pensavam os filósofos da Ilustração, Montelius acreditava que a tecnologia se desenvolveu por terem os seres humanos usado sua capacidade de raciocínio para industriar modos mais eficazes de lidar com a natureza, tornando assim as suas vidas mais fáceis e mais seguras. Suas referências à evolução biológica parecem ter sido concebidas principalmente como analogias destinadas a aumentar o status da arqueologia em um era dominada pelo evolucionismo darwiniano (..) sua posição no debate a respeito da inventividade humana foi tímida e seu pensamento, em grande medida, continuou evolucionista”

A citação de Trigger sobre Montelius nos mostra principalmente uma coisa. Que o método tipológico, e a maneira de pensar a história estão intimamente ligados, há uma linha de raciocínio clara entre a teoria e o método, e para Montelius, aparentemente, isso era bastante coerente. As mudanças seqüenciais nas tipologias criadas por ele eram vistas por ele como naturais e lógicas, sua visão teleológica talvez tenha sido, no terceiro quarto do século XIX, a inauguração desse pensamento nas ciências humanas.

Vicente Lull, analisando a epistemologia da interpretação histórica sobre culturas (Lull\&Micó, 1997) afirma que há uma linha contínua entre o evolucionismo e o histórico- 
culturalismo, "constituyeron soluciones matizadamente diferentes, pero compartían la misma inquietud que conformó la arqueología como sistema de conocimiento, a saber, la reconstrucción, explicación o comprensión de las formas de vida de los seres humanos en el pasado". Do seu ponto de vista, os arqueólogos ligados à corrente do materialismohistórico acreditavam que o modo de subsistência constituía-se como o devir principal das sociedades, a maximização da produção, o que facilitaria a obtenção de recursos, era visto como o grande avanço das populações. Esse avanço se dá de acordo com o tempo, e aí, para ele, que está o fundamento do evolucionismo social, como chave de explicação destes arqueólogos para historicizar o desenvolvimento das técnicas, que é o que gera a cultura material: "La tecnologia resulta clave en la obtención del sustento y ha configurado una solución adaptativa exitosa distinta a las seguidas por el resto de las especies.".

Lull e Micó criticam o materialismo-histórico como corrente da arqueologia pois a definição do que estes chamavam de estágios (sob a perspectiva do evolucionismo) se realizava a partir de uma síntese de características empíricas, através da análise dos artefatos. À essas características empíricas eram atribuídos grupos que definiam modos diferentes de obtenção de recursos naturais (caça, coleta, pastoreio, agricultura), ou seja, a materialidade, mais uma vez, definia o modo de subsistência. Em última instância, é este o parâmetro de delimitação de períodos. A crítica que os dois fazem é que, a partir dessa perspectiva, se procedia a abstrair outros conjuntos de elementos compartilhados das esferas sociais, políticas e ideológicos, que não se encaixam na proposta de seriação das formas sociais. Assim, quesitos importantes na definição de fronteiras imaginárias/identitarias/culturais, eram, para eles, suplantadas por uma visão funcionalista calcada em uma caracterização simplória de modos de subsistência.

A motivação epistemológica de desenvolver tal percepção de história das sociedades humanas, para eles, é puramente filosófica, parte do princípio que as pessoas, as coisas e o comportamento humano vão do mais simples ao mais complexo, base do princípio biológico de evolução, é o que chamamos de inevitabilidade do progresso humano.

Esse é um caminho perigoso a se seguir, não é intento aqui adentrar profundamente nele, mas a questão a ser pontuada é de que, detrás da idéia da inevitabilidade do progresso humano, está uma clara perspectiva de sucesso da nossa 
sociedade atual. De forma menos premeditada, talvez, os arqueólogos do início do século XX tivessem, portanto, concordância com o fato de que a sociedade estatal-capitalista era, até aquele momento o ápice do desenvolvimento humano. E por aí, se desenrola um corolário teórico que justificou centenas de anos de imperialismo das nações industriais sobre as sociedades latino-americanas, africanas e asiáticas. A concepção de que há um avanço positivo nas formas de organização das sociedades humanas, para Lull e Micó, é uma concepção que está ligada à formas de obtenção de recursos, e para eles, os arqueólogos e antropólogos que dividiam essa perspectiva acreditam que o industrialismo do século XX, portanto, era a foram mais racional e mais avançada de promover a continuidade da nossa sociedade.

De todos os elementos possíveis de análise, possíveis de servirem de lastro para a seriação histórica, porque o que criou raízes na academia foi este? Que privilegia uma visão material-funcionalista da análise das formas de subsistência? Porque se divide a história dos povos de acordo com aspectos que nem são nem econômicos, pelo contrário, são visões simplistas de obtenção de recursos? Qual o impacto da mudança de sociedades caçadoras-coletoras para sociedade agrárias?

O que qualquer sábio arqueólogo diria ser, talvez, efeito direto da "tirania do registro", pois afinal, estamos tratando do início da arqueologia como ciência moderna, soma-se aqui ao coro de Lull e Micó, e acredita-se que há, para essa visão, um fundamento filosófico-programático. Que está profundamente relacionado com uma visão de mundo, sob a qual o entendimento dos processos históricos constitui-se como lastro teóricoexplicativo.

A escola critica na arqueologia (McGuire, 2008, Trigger, 1998) colocou em cheque algumas máximas e mesmo com dificuldade, avança no campo teórico. Esse corpo teórico, que vai além do pós-processualismo, é bastante disforme, não possui aparente coesão epistêmica, é o que McGuire sutilmente chama de "bricolagem teórica", no entanto, o aspecto crítica da produção de conhecimento de alguns acadêmicos próximos a estas correntes nos é bastante útil para destrinchar o viés teórico dos conceitos utilizados por eles.

Shanks e Tilley (1987) foram a fundo no estudo da concepção teórica da formulação de modelos e conceitos na arqueologia. A ferocidade com que os dois 
criticaram determinadas abordagens é exultante, e bastante fundamentada, sua avaliação sobre a influência do evolucionismo social na arqueologia cabe ser citada, pois é confluente com a proposta apresentada. Para eles, as perspectivas evolucionistas tiveram influência na arqueologia principalmente em relação à respostas para mudanças sociais, concretizadas no desenvolvimento das ferramentas e da cultura material. Predominante em vários campos da ciência desde pelo menos o Iluminismo, onde para eles gerou-se a noção de progresso racional, essa visão de evolução social possui, na arqueologia, um aspecto político, que é o de confirmar, através de bases materiais, de que a mudança é um aspecto natural das sociedades, (pp147) e que estes processos são inexoráveis às vontades das populações.

Nesse sentido, a arqueologia serviu como uma ferramenta que foi apropriada por um programa político, que possui(u) respaldo na academia, e que desenvolveu um plano de fundo teórico onde colocam as sociedades à mercê de um jogo de regras préestabelecido, logo, passível de ser identificado no registro arqueológico. A visão unilinear e teleológica do desenvolvimento das formas de relação social, nesse sentido, corresponderia muito mais a uma perspectiva atual, do que propriamente emanada da cultura material. A mudança no registro arqueológico é inerente a sua própria existência, cabe ao arqueólogo, dizem eles, explicar como se deu, na longa e na pequena perspectiva, a mudanças sociais que resultaram na diferenciação tecnológica das ferramentas e outras representações das organizações sócio-políticas.

Eles resumem a influência das teorias de evolução social na arqueologia, até a metade do século XX, a partir dos seguintes sete pontos (pp144):

1. Holismo Totalizante: O primeiro objetivo dos estudos eram a história total da humanidade. Cultura com C maiúsculo era escrita e concebida como uma entidade essencialista

2. Gradualismo: Mudança social era concebida como um processo cumulativo e progressivo sem descontinuidade ou ruptura no processo histórico

3. Universalidade: Mudança era um processo natural e genérico que molda a humanidade e as instituições sociais

4. Potencialidade: Mudança era concebida como sendo endógena e um elemento inerente às sociedade humanas 
5. Trajetória direcionada: Mudança social vista como nem cíclica, nem aleatória, mas concebida como um processo unificado rumo à satisfação humana

6. Perspectiva Determinista: Mudança sendo tanto irreversível a inevitável, indo do simples ao complexo, do homogêneo ao heterogêneo

7. Reducionismo Causal: Mudança era, em todas as épocas e lugares, subordinada às mesmas leis de causa que conferiam ao processo social uma lógica fundamental.

O que nos mostram Shanks e Tilley, de maneira sucinta, são pontos chaves para entender a concepção de história que envolvia as pesquisas arqueológicas durante boa parte do século XX. A definição do Período Formativo está intimamente ligada a esta perspectiva, que teve uma forte aceitação nos Estados Unidos e na Europa tomou rumos um pouco diferentes. Nos anos 1940 e 1950, quando da gestação do conceito, a antropologia norte-americana vivia um momento profícuo de produção de dados etnográficos, muitos pesquisadores se deslocaram para zonas periféricas da guerra, como a África e a América do Sul, trabalhando tanto com contextos arqueológicos como com sociedade autóctones. A grande produção de dados, no entanto, não implicou em uma mudança epistemológica imediata, o termo e a noção de progresso continuaram em uso.

Os acadêmicos adeptos dos estudos evolutivos "classificavam sociedades de acordo com estágios de desenvolvimento, com a implicação de que sociedades que eram vistas em estágios rebaixados de desenvolvimento eram, de alguma maneira, fossilizadas neste estágio, e não haviam progredido ao próximo" (McGuire, 1999, PP 154), enquanto a sociedade européia, por exemplo, havia percorrido todos as etapas destinadas à todas as populações do mundo. O evolucionismo cultural entrincheirou-se na academia de uma maneira tão enraizada que é quase imperceptível que essa noção é uma abstração construída, e não um fato dado, como aparentemente é vista em muitos estudos.

O Período Formativo surgiu a partir de uma lacuna na explicação dos momentos históricos, é justamente uma maneira de compreender um processo de mudança social específico. Partindo da ideia de que as sociedades possuem um sentido universal de compreensão histórica, e rumos homogêneos, a recorrência de determinados elementos da cultura material de distintas sociedades serviram de sustentação, dando coesão a um "visão totalizante". Foi a maneira "sutil" de explicar porque, a partir de determinado 
momento da história humana, a produção cerâmica tornou-se preponderante em Cahokia, em Pueto Hormiga, em Valdivia e em Kotosh, ao mesmo momento em que floresciam, nestas mesmas sociedades, estruturas hierárquicas e sedentárias, e a economia começavase a se organizar ao redor da produção agrícola intensiva.

Não se sabe ao certo quando o termo Formativo apareceu pela primeira vez na literatura. Segundo Megger e Ford (1959), ele foi elaborado e concretizado por Willey \& Phillips no clássico Method and Theory in American Archaeology, de 1958. No entanto, eles mesmo citam, em uma nota de rodapé, que a toponímia foi influenciada por uma publicação de 1948, de Julian Steward, chamada "Functional -Development Classification of American High Cultures". Julian Steward, e aqui vale um parênteses para explicar um pouco de sua participação, foi um antropólogo norte-americano da metade do século XX, que criado na escola Boasiana, "adotou uma concepção explicitamente materialista do comportamento humano" (Trigger, 1999), onde defendia, ainda nos 1930, de que os arqueólogos, para compreender a natureza das mudanças culturais, deveriam abandonar a análise estilística dos artefatos e usarem seus dados para estudar as mudanças nas "economias de subsistência, no tamanho da população e nos padrões de assentamento".

Steward (Viveiros de Castro, 1996) acabou tendo uma significação enorme para a etnografia e para os modelos de desenvolvimento social nas terras baixas da América do Sul (Barreto, 2014) Principalmente em relação à tipificação das sociedades ameríndias contemporâneas, que, para fins de comparação analítica, dividiu as populações indígenas em modelos culturais, conformados a partir da uniformidade de determinados traços sociais, que homogeneizava-as em determinados aspectos, para ele, essenciais. Ao impulsionar e editar o Handbook of South American Indians (1948), Steward consagrou a perspectiva evolucionista no estudo etnográfico das sociedades originárias da América, ao dividi-las em grupos culturais que, ao mesmo tempo, representavam estágios distintos de desenvolvimento sócio-econômico (Neves, 1999).

Steward, ao estabelecer elementos comparativos que avaliavam as formas de organização social, econômica e política das populações ameríndias contemporâneas que se distribuíam ao longo do continente, enxergava nas atuais sociedades, o trajeto completo da história do desenvolvimento humano. Das Terras Baixas da América do Sul, era possível identificar, por exemplo, elementos de simplicidade de relações sociais e de 
obtenção de recursos que sociedades mais desenvolvidas, como as andinas, já haviam passado a muitos séculos.

Essa ideia anacrônica foi recorrente em muitos estudos de sociedades vivas, como o trabalho de Sharp (1952) na Austrália, onde, ao analisar os machados de pedra de tribos Aborígenes, os define como "representantes a Idade da Pedra, ou do Paleolítico". O método analítico de Steward, que possibilitou que ele estabelecesse uma divisão das sociedades de tal maneira, possui um embasamento teórico da antropologia econômica do final do século XIX e início do XX.

Steward tem um papel importante na literatura especializada pois, juntamente com Robert Lowie, estabeleceram as bases teóricas para o entendimento das formas de organização social das sociedades da Floresta Tropical, explanados no capítulo III do Handbook of South American Indians. Seu papel, no entanto, assim como seu embasamento teórico, tiveram o logro de se perpetuarem na produção acadêmica, por motivos que vão além de suas qualidades técnicas, e influenciaram não só a construção do "Tipo de Floresta Tropical", mas principalmente a lógica do desenvolvimento e da periodização histórica das sociedades americanas. O mesmo tipo de crítica que se faz à função racionalista dos tipos culturais de Steward deve ser feita, em grande medida, ao modelo epistêmico do qual ele foi um dos grandes difusores.

À mesma lógica aplicada no HSAH, Steward propôs, no "A FunctionalDevelopmental Classification of American High Cultures" (1948b), à divisão das culturas norte-americanas, levando em consideração o caráter tempo: substituiu o "tipo" por "período", e a função do método continuou a mesma. Ele analisou basicamente sociedades pretéritas de lugares onde notoriamente se desenvolveram sociedades estatais. Segundo Willey \& Phillips (1967), esta foi a primeira periodização publicada por ele, a avaliação que eles fazem dessa perspectiva é que a:

"functional-developmental" classification of American high cultures is a scheme for equating the major developmental stages of Middle American and Andean civilizations. These equations are made on the basis of technology for the earlier stages and upon what might be called general configuration in development for the later."

Ele definiu seis estágios de desenvolvimento para as sociedades analisadas: 1. PréAgricultura; 2- Início da Agricultura Básica; 3- Desenvolvimento Intra-área Básico ou 
Formativo; 4- Desenvolvimento Regional ou Formativo. 5- Florescimento Regional. 6Império e Conquista.

No entanto, a primeira tentativa mais generalizada de estabelecer uma seriação estratigráfica dos períodos históricos de toda a América pré-colonial foi organizada por Steward em outro artigo, de 1949. Essa publicação fez relativo sucesso nos anos 1950 e 1960, sendo constantemente citada pelos arqueólogos norte-americanos, e eventualmente, aplicada a contextos euro-asiáticos (Wittfogel, 1957). "Cultural Causality and Law: A Trial Formulation of the Development of Early Civilizations" é um tratado da concepção de cultura de Steward, e um reflexo do pensamento da antropologia norte-americana da metade do século XX. Refuta veementemente o particularismo de Boas, e o evolucionismo de Spencer e Morgan, e propõe uma análise mais objetiva dos dados arqueológicos. De maneira geral, não consegue fugir nem de um, nem de outro, mas apresenta uma interessante tese de síntese que tem como tema central a análise de regularidades culturais que, eventualmente, conformam períodos e tipos históricos. Seu argumento, é baseado na seguinte assertiva:

"If the more important institutions of culture can be isolated from their unique setting so as to be typed, classified, and related to recurring antecedents or functional correlates, it follows that it is possible to consider the institutions in question as the basic or constant ones, whereas the features that lend uniqueness are the secondary or variable ones" (pp6).

A partir dessa concepção de cultura que, do seu ponto de vista, hierarquiza determinados elementos que são genéricos, Steward distancia-se de uma visão orgânica de cultura, pois considera alguns pontos característicos das sociedades como sendo mais "básicos e fixos" (primary features) do que outros. O desafio do arqueólogo, e é o que ele intenta no artigo, é definir quais elementos que compõe o sistema da sociedade que seriam essenciais para explicar a origem e o desenvolvimento das mesmas. Ele resume estes elementos como sendo aqueles que "individual scientists are most interested in studying and which the anthropological record shows to have recurred again and again in independent situations"(pp.7).

Sua seriação abarca culturas arqueológicas do mundo inteiro, ele mira para áreas onde se enxerga a presença de sociedade estatais (Mesopotâmia, Egito, China, Mesoamérica e Peru) e tabula os períodos históricos do desenvolvimento humano das mesmas desde o Paleolítico até a Era Industrial 
Em uma de suas classificações deste artigo, as Major Eras, Steward (1949) define pela primeira vez o que seria o Formativo, um período presente em todas as seis regiões do mundo, em momentos diferentes, e que se encontra entre as eras "Agricultura Incipiente" e "Florescência Regional". É caracterizada pela aparição de tecnologias como a cerâmica, cestaria, tecelagem, metalurgia e construção, somados ao "nascimento de padrões de comunidade cultural", em um período de estabilidade econômica e crescimento populacional. Coloca também como sendo o momento em que se estabeleceram as primeiras divisões de classe, concretizadas na diferenciação da distribuição de recursos cultiváveis e de bens manufaturados.

O Formativo diferencia-se da Era de Agricultura Incipiente pela consolidação econômica, predominância da produção de bens manufaturados como a cerâmica, e pela plenitude da estabilidade das populações, conformando comunidades. A Era de Florescimento Regional distingue-se do período anterior pela consolidação da instituição administrativa das sociedades baseadas na teocracia, pelo aparecimento de tensões político-militares e pelo desenvolvimento do comércio como elemento estrutural na diferenciação cultural dos grupos.

Steward aparentemente não preocupou-se tanto em tomar tempo para explicar os processos de mudança de uma era para outra. De sua explanação, entende-se que ele enxerga a configuração das eras como algo sólido, e naturalmente transitório, ou seja, propenso à mudança evolutiva. No entanto, ele lança algumas luzes sobre o desenvolvimento das relações sociais na passagem do Formativo para o Florescimento Regional, em que se destacam o papel das forças de mediação entre a produção agrícola, o aumento populacional crescente e a ideologia. O desenvolvimento de elites locais, diferenciando-se uma das outras, e constituindo-se como agentes do monopólio das práticas rituais e religiosas criou um ambiente onde "floresceu" a divisão clara de classes e desenvolveu-se um ente político-religioso, que é o que chamamos de Estado. Trata Steward, no entanto, de locais específicos do mundo em que as sociedades destacadas desenvolveram-se de fato até o ponto de constituírem burocracias estatais, nesse contexto, dois elementos são importantes para justificar a ausência de comentários sobre as regiões não citadas: a falta de dados consistente sobre áreas periféricas das culturas "civilizadas", e a perspectiva determinista ambiental e difusionista, que aparecem ainda que de foram tímida no artigo, mas que explicam desde a incapacidade do desenvolvimento de técnicas 
agrícolas em determinados ecossistemas, como o processo de propagação de tais tecnologias.

Em 1955, Steward conformou um Simpósio na cidade de Tucson, nos Estados Unidos, a fim de debater com arqueólogos do mundo todo, a sua seriação cultural. "Las Civilizaciones Del Viejo Mundo y de America" foi definido por ele como um "simpósio de evolução cultural", em que ele desenvolve mais profundamente o "evolucionismo multilinear", sua concepção de desenvolvimento apresentado no artigo de 1949. Trata-se de uma perspectiva que "se interessa nas relações de causa e efeito que se apresentam em um número dado de culturas concretas" e nos "processos comuns de todo o desenvolvimento cultural" das sociedades. Na introdução da publicação do seminário, portanto, ele atualiza seu programa teórico taxonômico das sociedades ao longo do tempo, deixa claro que a razão principal da realização daquele era a de testar a seriação de 1949 e adequá-la aos novos dados que surgiam com o desenvolvimento das pesquisas.

Neste simpósio, arqueólogos de seis áreas (Mesoamérica, Andes, Mesopotâmica, India, China e vale do Mississipi) apresentaram especificidades de seus locais de estudo, dados que contribuiriam para o formulação de Steward. Este, por sua vez, reformula o esquema das Eras proposto seis anos antes, compreende que alguns tipos culturais necessitam ser homogeneizados para que sejam aplicados ao conjunto dos sistemas culturais do mundo, diminuindo as categorias antes apresentadas.

O Formativo permanece, nesta publicação, como um período consolidado, abarcando no entanto, o período que antes ele definiu como "Agricultura Incipiente", pois as características desse último apareciam de forma diluída e diferenciada em contextos distintos, e não da maneira uniforme que ele apresentou. O principal marcador entre os períodos Arcaico e Formativo passou a ser de forma categórica, a cerâmica. Reforça, ao mesmo tempo, a diferenciação entre o Formativo e o Florescimento Regional, sendo este último, o depositário de toda e qualquer característica ligada ao Estado ou a centralidade religiosa. Aproxima-se, nesse sentido, à diferenciação que Childe faz entre Neolítico e Urbano, considerando que a diferenciação estabelecida pelo australiano entre estas são basicamente as mesmas entre Formativo e Florescimento Regional.

Ao redefinir o Formativo, ele diz que este se configura como um "estado mal definido de mudança que culminou nos Estados Teocráticos de Regadio", um momento em que 
começa-se a ver as causas imprescindíveis que gerarão as estruturas estatais. Para nós, entende-se que esta é a definição que irá consolidar-se na literatura arqueológica. Mais do que a qualificação de elementos da cultura material como a cerâmica, ou a pedra polida, é a noção de que determinada sociedade, através de sua tecnologia e ideologia, possui elementos que propiciam o desenvolvimento do Estado, da civilização.

É preciso pontuar, no entanto, que o período Formativo, desde a concepção de Steward, não é, de maneira alguma caracterizado como um momento de instabilidade, muito pelo contrário. Assim como Childe, o antropólogo norte-americano também via, na segurança econômica da agricultura e pastoreio de subsistência, no controle populacional, no estabelecimento das linhagens e clãs, o advento concreto da estabilidade, da coesão sócio-política e do fim da obscuridade cultural das sociedades humanas. $\mathrm{O}$ aparecimento dos agentes reguladores das relações sociais, ou pelo menos claros indicadores seus, como a religião e a hierarquia social são, sem dúvida, um avanço para Steward. O caráter transitório, no entanto, este sim é um elemento muito presente, e é a essa perspectiva que devemos prestar atenção ao analisarmos as interpretações das designações do Período Formativo.

Dizemos isso pois a partir desse momento, inaugurar-se-á uma comum perspectiva na academia de, ao debruçar-se sobre os estudos das transformações sociais, mirar muito mais para o que se transformou, do que analisar objetivamente as significações das mudanças em si. Steward alerta para esse problema, e intenta, a todo momento, justificar sua seriação dizendo que ele estava preocupado com as especificidades de cada um dos contextos que sofreram mudanças, mas vimos que, no limiar da sua opção teórica, o que pesou como atributo de forte peso na definição do "estado formativo" foram as formas de organização política posteriores.

Estas duas publicações de Steward são provavelmente as primeiras publicações onde o termo "Formativo" foi empregado. Se houveram outras, e não descarta-se a hipótese de que um trabalho mais detalhado sobre a bibliografia as encontre, é seguro dizer que foram as obras que mais pesaram na concepção e consolidação tanto da lógica de seriação dos períodos pré-históricos na América, como na manutenção dos termos etimológicos cunhados. 


\section{$\underline{2.3 \text { Willey \& Phillips e a consolidacão do Formativo }}$}

Já dissertou-se acerca da forte influência da concepção antropológica e dos trabalhos de Julien Steward para a academia norte-americana do pós-guerra, os anos 1950 foram o auge da expressão de um método específico de fazer ciência que tiveram a contribuição direta dele. Steward influenciou diretamente um de seus alunos, Gordon Willey, que por insistência do primeiro foi levado ao Peru para realizar estudos de assentamento no vale do rio Virú, desenvolvendo uma das primeiras teorias acerca da formação de sociedades estatais no altiplano andino (Renfrew \&Bahn, 2008). Phillip Phillips, James Ford e James

Griffin são outros exemplos de então proeminentes arqueólogos norte-americanos que fizeram carreira no continente americano aplicando, de certa maneira, a seriação original de Steward

No final dos anos 1950, Willey e Phillips sistematizaram, na América do Norte, o que já havia de produzido em relação à classificação de culturas arqueológicas, além dos trabalhos publicados por Steward, Alex Krieber (1944) também destacou-se com uma classificação, que por exemplo, consagrou o termo "paleoíndio". Para os dois norteamericanos, as classificações de seus antecessores careciam de dados arqueológicos concretos, embora sofisticadas, era preciso dar coesão sistêmica às propostas.

Em sua publicação de mais fôlego, Method and Theory in Archaeology (1959), eles estabelecem a seriação das formas de organização sócio-político-econômico que se tornaria hegemônica na literatura especializada. Para eles, há uma diversidade de elementos e critérios que definem os estágios. De antemão, estabelecem uma clara diferenciação entre grupos agricultores e não agricultores, diferenciação essa que é recorrente em todas as partes do mundo, dizem eles. Tendo essa divisão como eixo principal, os critérios que definem os estágios entre elas são distintos, Willey e Phillps utilizam elementos para classificar estágios de sociedades agricultoras que não são os mesmos que utilizam para classificar sociedades de economia caçadora-coletora.

Para sociedades que não possuem agricultura, o critério de classificação é "puramente tecnológico, se refere a tipos de artefatos e tradições tecnológicas"; e para sociedades agricultoras, "o critério de divisão de estágios é muito mais complexo", baseado no conceito de Robert Redfield (1953) de "ordem moral”, conceito este que abarca elementos ligados à organização sócio-política, estética e religião. 
Não há portanto coerência por parte dos dois arqueólogos, na elaboração de critérios comuns para divisão dos estágios. Eles argumentam que os dados arqueológicos falam mais alto, e justamente, não se pode continuar pairando sobre uma bruma de elucubrações teóricas. Dizem eles:

Our method of formulating stages was to review archaeological sequences from all parts of the New World in local and regional detail, on an area basis and with reference to cross-areal comparisons. Our first concern was to set up a series of trial stages by seeking for clues to generalization between areas. We drew generalizations, tested them by going back to primary sources on the regional and local levels, and thus came to recognize certain "common denominator"criteria for each of the stages.

O intento dos dois foi juntar o máximo de informação possível, de dados brutos, dispersos e, influenciados fortemente pelas correntes histórico-culturalistas, e aplicar-lhes os tradicionais métodos de seriação intra-sítios em uma escala continental, sobre sistemas complexos de organização social. O caráter positivista com que eles empenham suas classificações dá uma aparente credibilidade científica neutra, através de um mecanismo denominado "developmental interpretation". Esse tipo de interpretação reforça a perspectiva de uma história concreta, baseada na significação das características de determinados dados que possuam importância na classificação de unidades básicas. Em linhas gerais, não era muito diferente do que os histórico-culturalistas faziam com a seriação cerâmica, ao estabelecer critérios específicos aos tipos, mas que dessem sentido a uma coesão de atributos. Sendo assim, os critérios que separam os estágios Lítico e Arcaico são completamente distintos dos que dividem, por exemplo, Clássico e PósClássico, porém, fazem sentido, dizem eles, quando observados os dados arqueológicos de maneira autônoma, o conjunto "artefatual" define-se por si mesmo. É uma taxonomia sui generis.

O conceito de Estágio Formativo é definido por eles pela presença de uma economia agrícola de milho e/ou mandioca, um sistema sócio-econômico bem sucedido presente em um estabelecimento sedentário. É portanto, caracterizado não por elementos tecnológicos, como cerâmica ou artefatos líticos polidos, mas pela existência de um tipo predominante de obtenção de recursos alimentícios (agricultura), sob o qual o resto da economia gira, combinado com um modo de vida sedentário, materializado na estrutura de pequenas vilas, ou povoados incipientes. São "culturas" possuidoras de um grau mínimo de complexidade social, onde é possível identificar os primeiros registros 
concretos de migração e de difusão de culturas uniformes, influenciando outras e colonizando territórios.

Não significa o advento da agricultura, alertam eles, pois a domesticação de plantas e a disseminação da prática agrícola é comumente encontrada em contextos do Estágio Arcaico, como sítios em Middle Woodland; da mesma forma que não representa a sedentarização, pois "culturas" da Costa Noroeste dos EUA, que eram sedentárias e possuíam uma economia "caçadora-coletora-pescadora", não foram enquadradas nesse tipo. Classificar o Formativo não é fácil, eles mesmo afirmam, e as definições parecem um tanto quanto descoladas dos dados apresentados.

O Estagio Formativo para eles é uma etapa, é a identificação de condições sócioeconômicas de sociedades que evoluiriam para o Estágio Clássico. Sua perspectiva teleológica é tão clara que, ao dar exemplo de culturas Formativas, eles citam que são abundantemente encontradas na Meso-América e nos Andes Sul-Americanos, locais onde o senso comum facilmente relaciona com desenvolvimentode instituições do tipo estatal. "They ocuppy a geographically central position in the Western Hemisphere", dizem eles, com as raras exceções do vale do Mississipi, na América do norte e, "talvez", em algumas regiões do Caribe e da Amazônica.

O que é possível perceber das definições de Willey e Phillips é que o Estágio Formativo corresponde, na verdade, a uma concepção de desenvolvimento, antes de ser um processo, é uma possibilidade de ascensão, representa as condições para as quais instituições estatais são geradas, economias tornam-se mercantilizadas e a desigualdade social é aprofundada. O Estágio Formativo é a ante-sala do Estado, é a obstáculo à civilização.

Mesmo assim, os exemplos subseqüentes citados por eles, sejam na América do Norte, ou Meso-Andinos, exemplificam a dificuldade com que os dois tentam tipificar contextos culturais, colocando em dúvida atributos como "agricultura", "vila sedentária" e "economia produtiva de subsistência". Ao estabelecer o Estágio Formativo como um tipo, eles estavam mirando muito mais para as formas sociais que se desenvolveram posteriormente nos ditos locais, do que para o registro propriamente. É o que explica a dificuldade de estabelecer padrões qualitativos para designar esse período; o Formativo 
como um ente cultural específico, foi definido desde o início como uma etapa transitória, muito mais do que um período estável.

Lyman et all (1997) dizem, a respeito da divisão estabelecida por Willey e Phillips, que esta é o resultado de uma concepção de mudança cultural que foi constantemente atualizada, desde o século XIX. Para os dois, Method and Theory (1959) representa o último suspiro do culturalismo-histórico, em um momento de reviravolta metodológica, mas mesmo assim, a concepção de que existe um aspecto progressivo de evolução cultural, concebido por Morgan, Spencer e Tyler (pp221) "estava vivo e bem” no final dos anos 1950. Ao avaliar conceitos que indicam processos como "progressive increasing cultural complexity", Lyman e O'brien traçam um desenvolvimento da tradição históricoculturalista com fortes raízes na epistemologia apresentada, tal qual como o que foi dito por Steward. Da mesma forma, observam que Willey e Phillips não desenvolveram nenhuma teoria nova, pelo contrário, assumiram uma teoria evolucionista acerca do conceito de cultura, e "timidamente" declarar aram isso.

A implementação do termo Formativo, portanto, não representou o resultado de um embate teórico, ou a síntese de uma disputa ideológica, foi o caminho natural seguido por estes arqueólogos em contextos até então pouco explorados da arqueologia americana. No caso das terras baixas, a experiência classificatória das "altas sociedades" americanas serviu de base para transpor conceitos que já nasceram com a perspectiva de serem continentais, e que acabaram se tornando o centro de debates durante os anos 1960.

Duas obras do Smithsonian Institute tornaram-se icônicas no registro histórico da definição do conceito de Período Formativo, e retratam a importância que a arqueologia da Floresta Tropical teve no desenvolvimento do pensamento histórico-culturalista. Talvez pela escassa produção de dados das regiões de floresta tropical sul-americana, ou pelo impressionismo inicial com os resultados de pesquisas recentes nas calhas do rio Amazonas, Napo e Orinoco, o Formativo Amazônico alcançou o centro de debates da arqueologia americana em pouco tempo, e esses dois volumes de "Smisthonian Contributions to Anthopology" (1959; 1965) não deixam de ser retrato disso.

Em 1965, sete anos portanto depois da publicação de Willey e Phillips, o volume 1 da citada obra, editado por Betty Meggers, Cliford Evans e Emilio Estrada, apresenta os interessantes dados dos sítios arqueológicos do litoral Equatoriano, das fases Valdivia 
e Machalilla. Essas fases cerâmicas seriam, segundo os autores, exemplos mais antigos da presença dessa tecnologia na América, então com datações por volta do quinto milênio antes do presente. $\mathrm{O}$ trabalho consagrou a visão ambientalmente determinante dos autores, e a perspectiva degeneracionista de cultura, que seguiu com o casal Evans quando, décadas depois, procuraram explicar a complexidade da sociedade Marajoara.

A noção de cultura apresentada na introdução do livro, por sinal, nada difere do que os culturalistas-históricos estavam produzindo há 40 anos atrás:

"Culture, being the principal instrument of man's adaptation to his physical, social and biotic environments, is subject to similar continued pressures. Cultural change can be seen as the result of selection of more adaptive traits, whether of technology, socio-political organization or other aspects of culture. From this point of view, social disorganization may be a reflection of loss of adaptive value for the cultural configuration, rather than a primary cause of cultural breakdown."

O Formativo já aparece, aqui não como estágio, mas como Período, e não mais como um conceito dúbio, mas como uma unidade temporal bem definida e autoexplicável. Os autores não procuram retomar em nenhum momento os problemas metodológicos que atormentavam Willey e Phillips. O capítulo teórico, outrossim, é dedicado à uma extensa explanação sobre o método Ford (1950) de seriação cerâmica, e as implicações das sub-divisões das fases e a relação destas com o conceito de cultura. Emilio Estrada, certamente, teve um papel importante na consolidação do termo, desde 1956, ele já vinha publicando artigos e livros a respeito da cultura Valdívia, relacionandoa ao Período Formativo. Sua definição de Formativo, no entanto, é definida basicamente pela presença/ausência de cerâmica.

A outra publicação do Smithsonian, o volume 2 de Contributions to Antrhopology, foi editado por James Ford em 1969, e o título já apresenta, em linhas gerais o conteúdo: A Comparative of Formative Cultures in America. Diferente de Meggers et all (1956), Ford coloca alguns pontos que tem em desacordo com a definição de Willey e Phillps, reforça o aspecto de divisão da história dos culturalistas -históricos, dá grande importância para os trabalhos pioneiros de Valliant e Kidder, por exemplo, e se vê, de certa forma, como fruto desse processo.

As considerações que este faz à definição original do contexto é muito fruto do crescimento abundante de dados produzidos na América, além do que, ele possui, quase dez anos depois, um cenário de contextos arqueológicos continental muito mais completo 
e complexo. Ele enxerga as falhas dos seus antecessores ao procurarem atrelar, como elemento definidor do Período, a agricultura, a estabilidade e a cerâmica, como se fossen um processo inexorável, um pacote tecnológico que surgisse ao mesmo momento em todos os lugares. No caso da costa peruana e das terras altas mexicanas, por exemplo, há indícios de agricultura antes do aparecimento da cerâmica ou de instrumentos líticos polidos, e aparentemente, não estão ligados a um processo de adensamento populacional. A relação entre cerâmica e agricultura tampouco possui lastro nos dados ao longo do continente, como dentro das distintas culturas não apresentam, em muitos casos, coesão cronológica, pelo contrário, o aparecimento da tecnologia cerâmica, aparentemente, pouco teve a ver com o advento da domesticação. As culturas da costa peruana, Valdívia, e a região do vale de Oaxaca eram exemplos concretos para eles no final dos anos 1960.

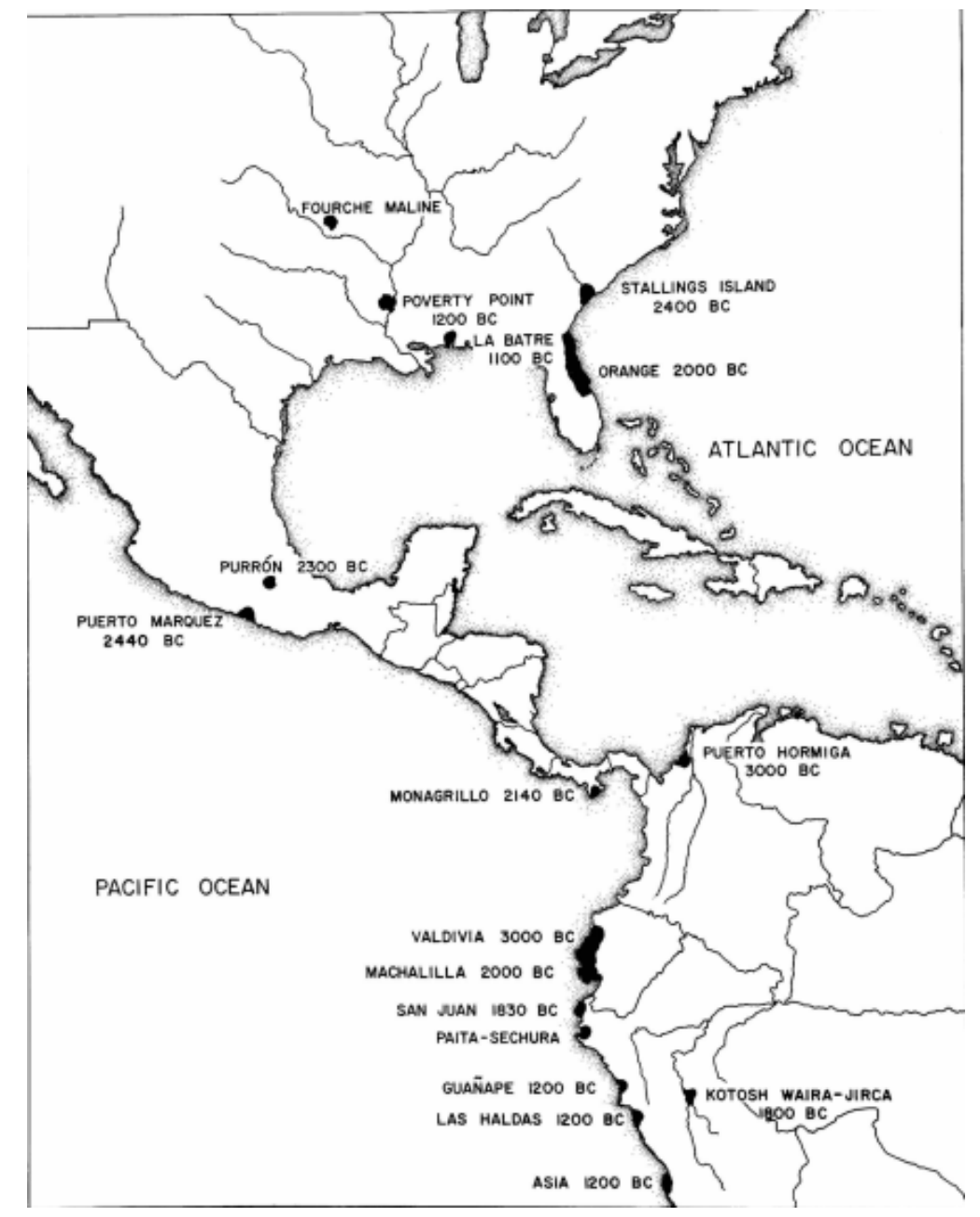

Figura 3: Culturas Formativas e suas respectivas idades no continente Americano. Adaptado de Ford (1969) 
Em 1969, portanto, a arqueologia já constatava um problema no trinômio "AGRICULTURA-CERÂMICA-SEDENTARIZAÇÃO", pois os três, em nenhum dos contextos estudados, apareceram, tal qual no Velho Mundo, de uma só vez, representando de fato um processo de ruptura bruta na economia vigente. De antemão, diz ele, os arqueólogos acertaram ao definir uma macro-divisão entre grupos caçadorescoletores e grupos sedentário-ceramistas-agricultores, a grande questão para ele é explicar o que se passou entre estes dois estágio de evolução cultural. O Período Formativo para Ford é, portanto, antes de ser um estágio, um PROCESSO, seu argumento é mais dialético do que o de Willey e de Phillips, que também enxergam instabilidade nesse estágio cultura, no entanto, Ford, ao apresentar mais variáveis, e problematizar consistentemente a unidade classificatória, a apresenta muito mais como um "meio termo", do que como algo que pode ser categoricamente, ou objetivamente identificado. Diz ele:

"For these reasons it is preferable to define the Formative more loosely as the 3000 years (or less in some regions) during which the elements of ceramics, ground stone tools, handmade figurines, and manioc and maize agriculture were being diffused and welded into the socioeconomic life of the people living in the region extending from Peru to the eastern United States. At the start of this span of years, all these people had an Archaic economy and technology; at its end they possessed the essential elements for achieving civilization."

Mais uma vez, o Período Formativo é definido não pelo o que a cultura arqueológica é, mas pelo o que poderá a ser um dia. As sociedades enquadradas no Período Formativo por Ford são constituídas de uma história já construída, onde há um inicio de costumes bárbaros, economia simplista e tecnologia incipiente, e um fim de pleno desenvolvimento político e estabilidade econômica. No meio do caminho, a explicação de como A vira B, é o Período Formativo para ele, um processo natural do caminhar das sociedades Arcaicas que, em um vasto período de 3000 anos, deixaram vestígios de um processo ascendente que indicam cada vez mais, a complexificação social das mesmas.

Como traços distintivos desse período, Ford reluta em apontar um "check-list" de elementos da cultura material, muito pela diversidade das formas com que se deu esse processo ao longo dos exemplos na América, pois um determinado tipo de cerâmica pode ter sido importante para a sociedade de Poverty Point (USA), mas não para San Juan (Peru). Mesmo assim, de forma genérica, ele apresenta alguns elementos da cultura material que, por toda a América, parecem ser indicativos deste processo, como: vasos 
cerâmicos policromados, vasos cerâmicos modelados em formas antropozoomorfas, vasos cerâmicos em forma de barcos, estruturas funerárias feitas de rocha ou madeira em montículos artificiais, o uso de pigmentação vermelha em sepultamentos, fusos de cerâmica, líticos polidos em forma de cones, e pequenas efígies de animais, além de uma série de tipos de decoração de vasos cerâmicos, como incisões em forma de "U", representado o milho, ou modelados do tipo ungulado. (pinched).

O autor ainda faz uma elucubração sobre as divisões que existem entre o Período Formativo. Aqui vale um ponto de nota: desde as seriações de Kroeber (1925), o Estágio, ou Período Formativo, possuem inter-divisões. Além de retratar a dificuldade de estabelecer um parâmetro comum ao processo, repete a mesma lógica de divisão inicial, com o adendo de que, até 1950, devido à inexistência das datações de carbono 14, as divisões internas do Período tinham como função mais explicar as especificidades regionais em relação às dificuldades de estabelecer cronologias. Ford trabalha com dois períodos, o Formativo Colonial e o Formativo Teocrático. O primeiro, diz ele, representa o período em que a cerâmico foi "distribuída" em todo o continente, dos centros mais antigos de produção cerâmica, a tecnologia migrou, com ou sem seus fabricantes, tornando-se indispensável a certa altura, no estabelecimento de populações sedentária por todo o continente. O Formativo Teocrático, mais recente, está relacionado à mudanças de ordem político-ideológicas das populações, e corresponde, materialmente, ao aparecimento de estruturas construtivas de proporções consideráveis, de terra ou de pedras.

O aparecimento da agricultura, mesmo que em segundo plano, possui um papel importante na definição de Formativo para Ford, principalmente, porque é um pressuposto básico que uma civilização tenha condições materiais de estabilidade econômica e complexa estrutura agrária para que esta possa produzir estruturas administrativas estatais, manejando de forma coordenada e planejada a economia. Há, aparentemente, uma ligação íntima entre o desenvolvimento de práticas agrícolas sofisticadas, em grande maioria da produção de milho, e a ascensão de determinados grupos político-religiosos. Ford apresenta essa proposta, inovadora provavelmente, da relação dialética entre dominação econômica e dominação religiosa, como tendo sido o "real ímpeto do Formativo Americano". Ele chega a utilizar, mais como recurso de linguagem, acredita-se, a palavra "revolução" para designar o processo de mudança sócio-econômica em Chavín, Hopewell e a Costa do Golfo do México. Nesses três 
lugares, uma quantidade enorme de trabalho social começou a ser absorvida na construção de edifícios religiosos, e a clara estratificação social começou a ser vista em práticas de enterramento (Patterson, 2005).

Um elemento que vale ressaltar, tanto da publicação de Meggers (1959), que é retomada por Ford (1965), é a incapacidade de desenvolvimento tecnológico local, nos três exemplos citados acima, Ford afirma que a cerâmica que caracteriza o período nos três lugares (Chavín, Hopewell e Golfo do México) possuem uma origem comum, ele inclusive abraça a ideia da cerâmica Jomon, japonesa, migrada para a Costa do Equador. As tecnologias que definem o Formativo, a interdependência de desenvolvimento sócioeconômico-tecnológico dos centros indicados pelos autores parece não corroborar para as teses de povoação das Américas, não há pontas soltas nessa história do desenvolvimento das populações ameríndias. Ford (1950), claro, trabalha com as perspectiva da cerâmica como marcador cultural de identidade caracterizado por determinados traços distintivos que permitem conectar processos aparentemente tão diferentes.

A impossibilidade teleológica de encontrar desenvolvimento, mesmo que na lógica evolucionista, de elementos definidores do Formativo, causados por processos que poderiam ser estritamente locais, não corrobora com a tese geral da evolução social. As sociedades evoluem, sob essa ótica, pois possuem uma lei apenas e um caminho a seguir, a produção agrícola surge pelo mesmo motivo no vale do Mississipi e nos vales da costa norte peruana.

É isso que ele (Ford) chama de "unity psych of mind", um comunhão de elementos ideológicos, que cada ameríndio carrega, e que permite com que, em um exercício anacrônico, o desfecho destas organizações sociais sejam os mesmos. Ford vai além da concepção uniforme de cultura, ele designa à mente humana uma conformidade na forma de resolução de conflitos que ordena, a variedade de contextos arqueológicos que se apresentam. Existe, para ele, um motivo que faz com que a resposta a distintos problemas nas organizações sociais, seja resolvida através de mecanismos muito semelhantes.

Nesta expressão, originalmente utilizada por Adolf Bastian (Stocking, 1985), Ford incide à explicação geral dos processos de transformação das sociedades humanas, a partir de uma máxima filosófica de que as sociedades, dadas a sua unidade psíquica, impelem com que sejam duplicadas, logo, o desenvolvimento das formas mais "avançadas de 
organização social", na América, possuiriam necessariamente uma ligação com a o velho mundo.

Com a perspectiva de "unidade psíquica da humanidade", Ford afasta toda e qualquer capacidade de inovação e de mudança que ocorra fora de determinados padrões. É a teoria que, de forma sutil, explica a difusão das tecnologias, que conecta a América ao Velho Mundo. A última sentença de seu livro é o resumo da sua perspectiva de cultura, um fenômeno supra-orgânico, meio alheio às vontades e reflexos das convivências sociais em comunidade.

\subsection{O Formativo nas Terras Baixas}

Nas Terras Baixas da América do Sul, o Período Formativo tanto no senso comum como na literatura especializada é resultado da congregação das definições de Ford, Meggers e Steward, e poucos debates acerca de sua concepção se sucederam depois. Embora o tema tenha se desenvolvido como um profícuo campo de polêmicas, em relação à antropização da Terra Preta, da continuidade da ocupação das aldeias, da antiguidade da cerâmica, o cerne do debate não foi, em momento algum, a qualidade da seriação.

A definição de Formativo que acabou cunhada na literatrura das Terras Baixas pode ser resumida pela publicação da Maria Cristina Scatamacchia (1994), talvez a única reflexão especifica, na literatura brasileira, sobre o uso do conceito Formativo. Ela problematiza as dificuldade de utilização do conceito, suas implicações teóricas, e a raiz de sua formulação com a publicação de Willey e Phillips. Para ela, o emprego da terminologia, no anos 1990 de então, não estava sendo conduzido de forma sistemática por arqueólogos brasileiros nos contextos arqueológicos do leste da América do Sul, diferente de outras regiões do continente, onde a bibliografia já sustentava a presença de tal período.

Ela identificou, em levantamento bibliográfico, que entre os estágios utilizados pelos arqueólogos brasileiros não era citado o Formativo, sendo recorrente o uso de "Paleo-indio" e "Arcaico". Para ela, isso era resultado de uma visão preconceituosa e subjulgada da ciência nacional, "em regiões onde este estágio (Formativo) significou o ultimo nível de desenvolvimento", pois onde não eram identificadas culturas "superiores" ou estatais, não deveriam haver seus pré-requisitos. No entanto, diz ela, mesmo que esse último estágio não tenha sido ultrapassado, a passagem para uma economia produtiva 
aconteceu em toda a parte, afirmativa esta calcada no surgimento de características que definem o período em outras partes da América, como a cerâmica, o cultivo de alimentos domesticados, e a estabilidade das comunidades.

Sua proposta é a utilização do termo Período Formativo para os contextos das Terras Baixas, de modo que seja possível identificar "em que nível estariam as evidências culturais brasileiras", a fim de estudá-las comparativamente com outros contextos americanos. A definição do Formativo, para ela, constitui-se pela "vida sedentária em aldeia com base na produção de alimentos", somado à presença de cerâmica, em um primeiro nível; e posteriormente caracterizado pelo "aparecimento de chefias, com centros cerimoniais, fabricação de figuras de argila e outros traços ligados a este tipo de organização.

Scatamacchia não foge da receita de bolo de Ford, no entanto, sua perspectiva é distinta, chega a ser quase um emponderamento da arqueologia do leste sul-americano. Para ela, a utilização do termo Formativo é essencial para adequar a real análise do contexto arqueológico, o colocando em pé de igualdade com outras regiões da América, coma Floresta Tropical, inclusive. Para ela, mesmo que as culturas Tupi ou Aratu não tenham desenvolvido-se a ponto de virarem sociedades estatais, deve ser enxergado de maneira positiva que tiveram a experiências, estas sociedade, no Período Formativo.

$\mathrm{Na}$ região de florestas tropicais, ela aponta, já se empregava de maneira regular o termo Formativo. Desde os já citados Meggers e Evans, que trouxeram consigo, do Peru, a concepção histórica aplicada à arqueologia, e o explicaram de forma sistemática em diversos contextos amazônicos, um de seus maiores antagônicos, Donald Latrhap (1968, 1970), não caminhou por caminhos tão distantes.

As divergências entre as ideais centrais da ocupação humana entre Lathrap e Meggers para a floresta amazônica perpassam pelo debate acerca do Formativo. Já vimos que para Meggers e Evans, a ocupação humana na calha do rio Amazonas e afluentes se deu através de culturas que já chegaram às Américas com um repertório cultural onde já se destacavam a cerâmica e a agricultura, especialmente no ambiente tropical.

Este modelo de ocupação do território amazônico, que ficou conhecido na literatura como "Standard Model" (Viveiros de Castro, 1996), previa um movimento degeneracionista de sociedades andinas que, chegando no ambiente tropical e diante da 
suposta enorme quantidade de adversidades ambientais, não teria conseguido galgar passos na escada da evolução cultural, sendo impossibilitadas de desenvolverem grandes assentamentos nas áreas de floresta tropical. Meggers e outros pesquisadores do PRONAPA (Meggers, 1954, Meggers\&Miller, 2003), com essa perspectiva, retiravam a o protagonismo das sociedades humanas e de suas possibilidades de escolha frente a eventos e processos de mudanças sócio-culturais,

A arqueóloga (Meggers 1971) se baseou em diversos estudos comparativos com grupos indígenas contemporâneos, como Camayurá, Jívaro e Kayapó (Moraes, 2009) para definir os padrões de assentamento pré-colombianos, aldeias pequenas, independentes e isoladas nas áreas de terra firme da floresta tropical, excluindo a importância das redes de trocas regionais e estabelecendo um continuísmo em relação ao processo de ocupação europeia na região. A presença de eventuais complexos líticos, mais antigos que as ocupações ceramistas era visto como incursões pontuais de grupos caçadores-coletores originários da área Andina e circum-caribe. A presença de ocasionais contextos pré-cerâmicos na bacia amazônica, portanto, nunca poderia significar uma ocupação antiga e duradoura, pois a floresta não ofereceria, sem o manejo adequado de tubérculos específicos, proteínas e carboidratos necessários para a existência de culturas relacionadas a grupos caçadores-coletores.

No final dos anos 1960, Donald Lathrap (1968) se debruçou sobre os processos de estabelecimento de grupos caçadores-coletores na região da Amazônia. Embora a historiografia comumente o coloque em oposição as ideias de Meggers, pois ele defendia que a Amazônia Central poderia ter sido um grande centro irradiador de inovações tecnológicas (1971), no que tange ao tema proposto, as elucidações de Lathrap o colocam muito próximo da visão determinista do casal norte-americano. Para ele, os grupos da floresta tropical não teriam capacidade de sobreviverem apenas com a caça e com coleta sem acesso aos carboidratos oriundos dos tubérculos das sociedades que se organizam a partir da horticultura. A presença de sociedades caçadoras-coletoras no ambienta amazônico, portanto, seria o exemplo claro de um processo de aculturação e inadaptação a um novo ambiente, sendo a horticultura um fator elementar para o desenvolvimentos das forças produtivas de tais sociedades. Para ele, ou a economia basear-se-ia na agricultura, ou as comunidades não se reproduziriam. 
Em linhas gerais, esse quadro de análise da ocupação humana no Holeceno Inicial e Tardio na bacia amazônica permaneceu inalterado até meados da década de 1980, quando intensificaram-se alguns projetos arqueológicos em áreas de montanhas e abrigos.As escavações de Eurico Miller (1987) no sítio Abrigo do Sol, estado do Mato Grosso, publicadas no final dos anos 1970, consolidaram definitivamente a existência de grupos ditos caçadores-coletores na Amazônia. A complexidade do sítio fez inclusive com que o mesmo criasse um projeto específico para o tema, o Projeto Paleoindíogena (PROPA). No sítio Abrigo do Sol, Miller identificou pelo menos duas camadas préceramistas, separadas por um espesso paleossolo de coloração marrom-acinzentado. A primeira camada é representada pela indústria lítica que ele denominou Complexo Dourados, possui datações que vão de 8930 a 10600 AP; foram evidenciados, além de lascas de basalto, resinas, sementes de palmeiras carbonizadas e fragmentos de carvão lenhoso. A segunda camada, mais antiga, foi definida por Miller mais pela presença de elementos botânicos do que pelo material lítico em si, uma vez que ele não pode identificar antropização nos materiais rochosos. Possui datações de 12300 a 14300AP. (Miller, 2009)

Apesar dos dados levantados por Miller, foi somente em 1996, com a publicação de artigos da arqueóloga norte-america Anna Rossevelt que a comunidade acadêmica começou a aceitar a existência de duradouras e constantes ocupações ininterruptas ao longo do Holoceno na bacia amazônica. Seu trabalho na Caverna da Pedra Pintada, no Pará, revelou, de modo mais consistente do que Miller, a presença de uma série de elementos antropizados, como madeira carbonizada, buracos de lixo, espécies vegetais manejadas e restos faunísticos de peixes, tartarugas e grandes mamíferos. Foram identificadas mais de 30.000 peças de material lítico (Bueno \& Pereira, 2007), entre estas, 24 artefatos formais.

Nos locais onde essas antigas ocupações foram evidenciadas não existe correlato imediato de ocupações ceramistas posteriores. Tanto no alto Guaporé, como no baixo Amazonas, e na Amazônica Central, as antigas datas parecem pairar em um cenário de falta de dados que não indicam continuidades estratigráficas (Bueno, 2013). Nesse sentido, o período Formativo na Amazônia sempre foi caracterizado pela ausência de dados relativos à grupos caçadores-coletores, com a exceção do contexto do Alto Madeira. O que acabou por definir este período nas áreas de Florestas Tropicais são 
contextos estáveis onde os substratos mais antigos já conformam-se caracterizados pela agricultura, pela cerâmica e pela sedentarização

O Formativo, nesse debate portanto, sempre apareceu como um elemento exógeno ao desenvolvimento local das sociedades amazônidas. Muito devido à falta de longos perfis crono-estratigráficos que permitissem aos pesquisadores olharem, para um só lugar, e enxergar as ocupações pré-ceramistas sobrepostas imediatamente por ocupações ceramistas. Logo, o panorama que há, na arqueologia das Terras baixas, é o de espaços e localizados sítios com ocupações efêmeras datados do Holoceno Inicial e Médio, um grande hiato cronológico, e então, o recente movimento do aparecimento da cerâmica com, ou eventualmente, sem a Terra Preta.

A perspectiva difusionista, nesse sentido, nunca perdeu força, não por preconceito ou adoção teórica, mas exatamente pela falta de indícios de centros de desenvolvimentos locais onde seja possível ver o longo caminho percorrido por essas populações durante o Holoceno. A relação entre os antigos complexos cerâmicos Pocó/Açutuba e o Período Formativo são resultado dessa observação. Arqueólogos como Lima (2008), Gomes (2011) e recentemente Neves (et all 2014) retomaram a discussão de Hilbert \& Hilbert (1980) acerca dos antigos complexos cerâmicos das regiões de várzea da Amazônia, e com a formulação de novos dados, estão lançando luzes acerca desse processo.

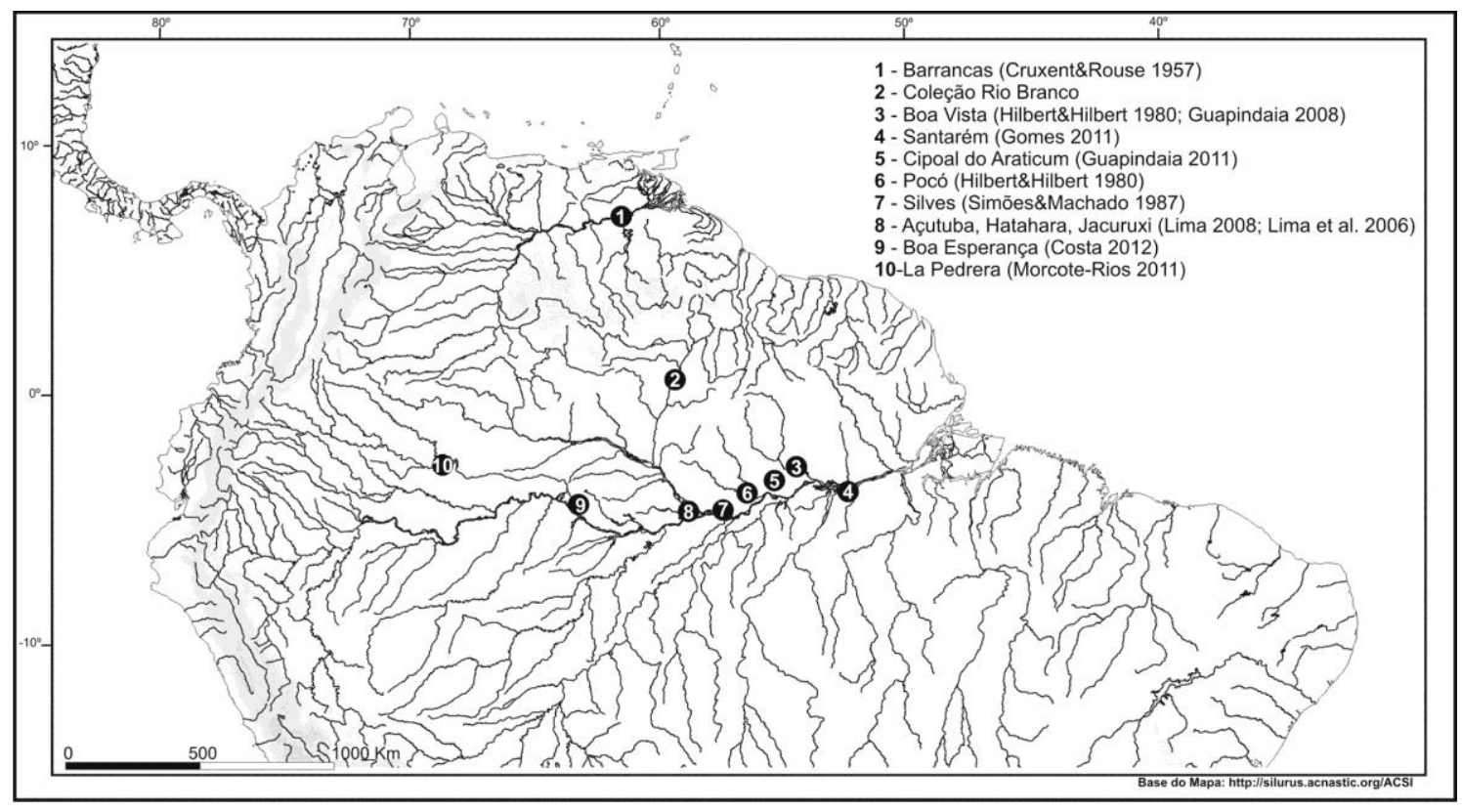

Figura 4: Adaptado de Neves (et all, 2014). Localização das culturas ceramistas relacionadas à Fase Pocó-Açutuba 
A fase Pocó/Açutuba é, para eles, a representação do "correlato arqueológico de populações com origem externa que começaram a se estabelecer em diferentes partes da bacia Amazônica na transição do segundo para o primeiro milênio", estão associadas "com a formação de solos de terras pretas ao longo do rio Amazonas e dos baixos cursos de seus afluentes". Estão relacionados com o estabelecimento dos modos de vida sedentários, "resultados de um processo de mudança social” (Neves et all, 2014)

Para Lima (2008) a concretização do Formativo é o resultado material de um processo de migração que estabeleceu as bases para um adensamento populacional ligado ao cultivo de bens cultiváveis e um padrão de vida sedentário. Por mais que tenha havido, anteriormente, indícios de cerâmica (como é o caso nos sambaquis fluviais do Norte do Brasil) ou de incipientes tentativas de domesticação de plantas (Pipperno, 1988), para esses autores é a estabilidade de um modo de vida que conjuga uma série da fatores que define essa tradição.

Para Arroyo-Kalin (2010), o debate vai pelo mesmo caminho, para ele, esse processo é caracterizado pelo momento em que as comunidades humanas "especializadas na caça e coleta passaram a depender dos recursos alimentares disponíveis" a maior parte do ciclo anual ou armazenáveis. Esse processo, econômico, possui uma relação de causa e efeito com a forma de assentamento e gerou o padrão de vida sedentário. Arroyo-Kalin crê que o novo grau de comprometimento destas populações com os alimentos de origem vegetal foi o motor das transformações culturais que levaram ao "desenvolvimento de novas e complexas formas de relacionamento social".

Ele aponta que a presença de solos antrópicos na Amazônia é um indicativo forte deste tipo novo de comprometimento, pois revelam, não só padrões de sedentarismo, mas também aumento populacional e interação crescente com o meio ambiente. Para ele, a hipótese de difusão de grupos vindo do norte do continente, trazendo consigo o knowhow da produção cerâmica e da domesticação do meio ambiente, principalmente com o cultivo da mandioca, é a proposta mais coerente para explicar a profusão de contextos tais quais os descritos em vários lugares da Amazônia por volta de 3000AP, e a esse processo migratório, ele relaciona também a cerâmica da fase Pocó-Saladoide.

Mesmo com tal assertiva, Kalin diz que há uma região da Amazônia que possui, aparentemente especificidades em relação à essa explicação: 
"Permanecem, então, perguntas interessantes sobre o papel da região do sudoeste amazônico (Neves 2008). São provenientes dessa região evidências de práticas de horticultura relacionados com antigas ocupações sedentárias pré-cerâmicas (MILLER, 1992b), evidências de sambaquis cerâmicos (MILLER, 1999; KIPNIS et al, 2005) de antiguidade equivalente àquela registrada em Santarém. Diante desse grupo de importantes evidências antigas, fica ainda por compreender como esta região se insere no quadro maior das manifestações arqueológicas amazônicas mais setentrionais"

A partir daqui, tentaremos inserir os novos dados obtidos no sítio Teotônio, acerca destes processos iniciais de modificação do meio ambiente, procurando compreender de que forma estes se relacionam com seus correlatos históricos. 


\section{3- O Sítio Cachoeira do Teotônio}

\section{1 - A Cachoeira do Teotônio : palimpsestos e uma história de longa duracão}

A Cachoeira do Teotônio é sem dúvida um dos lugares mais importantes na Amazônia. São diversos os elementos naturais que chamam a atenção, além da sua queda d'água, que em muito supera as outras 23 corredeiras do Rio Madeira, sendo, muitas vezes a não ser transporte por via fluvial, a piracema famosa entre os pescadores em todo o continente. De fato, antes da inundação da cachoeira pela barragem construída na cachoeira abaixo, em Santo Antônio, a visão da pesca nas pedras da corredeira podiam variar da incredibilidade ao espanto. A assombrosa quantidade de peixes que pululavam por entre as pedras, buscando o melhor ângulo para transpassar a barreira física gerava técnicas aprimoradas de pesca, que iam desde os malabarismos nos giraus ${ }^{6}$ que adentravam à cachoeira, parar zarpar o melhor peixe, até o simples ato de estacionar a canoa entre as pedras e esperar ela ficar cheia de peixes.

Impossível desassociar qualquer relação entre ocupação humana e ambiente num local desses, onde a oferta de recursos proteicos é gigantesca, e a força de trabalho para obtenção de tal pode beirar o nulo. Goulding (1979, 1997,), em um estudo clássico sobre peixes na bacia do Rio Madeira chega a afirmar ser esse trecho do rio é um dos lugares mais piscosos do mundo, tanto em quantidade como em variedade de espécies.

\footnotetext{
${ }^{6}$ Estrutura de tabuas de madeira entrelaçadas, formando uma espécie de "ponte" que adentra em direção ao centro do rio, constituindo uma plataforma para os pescadores.
} 


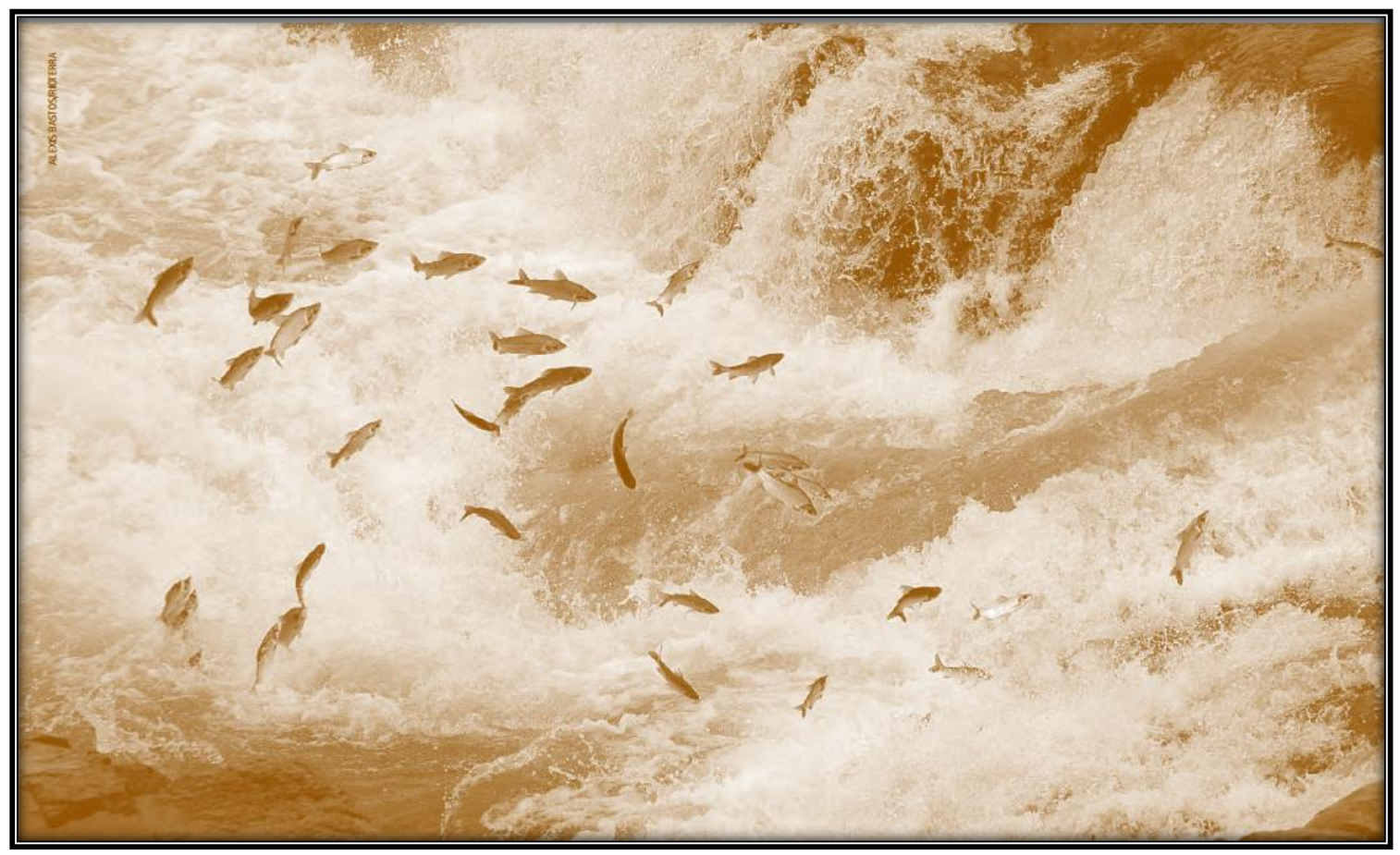

Figura 5 - Piracema na Cachoeira do Teotônio. (Foto de Alexis Bastos: Fonte:Switkes, 2008)

Os gigantismos das suas corredeiras foram o grande chamariz de vários cronistas que subiram e desceram o rio Madeira durante os séculos XVIII e XIX, todos dão especial atenção à maior das quedas d'água do Madeira, tendo sido extensamente descrita e desenhada diversas vezes.

O primeiro relato que se teve acesso, embora se tenha conhecimento de outros (Soares, 2012), foi a crônica do paraense Francisco de Melo Palheta, de 1723, que menciona sua subida pela rio Madeira, onde depois de passar pela Missão de Santo Antônio, encontrar a boca do rio Jamari, e cruzar a $1^{\text {a }}$ corredeira com a ajuda do Pe San Payo, relata: “aqui fomos à cachoeira chamada dos Iaguerites" ${ }^{7}$, onde chegamos vésperas de São João e nela vimos sem encarecimento uma figura do Inferno: porque tendo eu visto grandes cachoeiras" (Magalhães, 1939).

\footnotetext{
7 Segundo Navarro (2013), um vocábulo da Lingua Geral Amazônica, que significa "onça". Junção de duas palavras do tupi antigo: laguara=onça e Eté=verdadeiro. Começou-se a ser usada depois da colonização pelos indígenas na América para diferenciar o felino selvagem do cão, que também tinha a alcunha nos tempos coloniais de lagyar.
} 
Por volta de 1868, o engenheiro alemão Franz Keller (1874), a serviço dos governos brasileiro e boliviano, percorreu a região do Alto Madeira estudando a viabilidade da construção de uma ferrovia que pudesse facilitar o transporte do sudoeste da Amazônia, dificultoso por vias fluviais justamente devido à corredeiras. Ao chegar na Cachoeira do Teotônio, ele assim a descreve:

"Over a large soal and some flat islands, we could see already from Macacos, the next considerably rapid, the rising water-spray of the mighty fall of THEOTONIO. Between low hills running down to the water's edge on both sides, the river has hollowed a course of 2300 feet in breadth, through which it dashes at furious speed, terminating in a majestic fall 36 feet high.

On the ridge of a rocky hill on the right bank, we saw the remains of some walls, covered almost completely by shrubs, low palms and thorny torch-thistles. They date from 1753, when Theotonio Gusmao, by the direction of Portuguese Government, here founded, in a very good position for defense, a military post, which, was, however, soon abandoned. “

A citação de Keller, que se assemelha muito a outros relatos de cronistas coloniais, no entanto, se destaca por ser a primeira a tratar a Cachoeira não só como um fenômeno natural, mas também histórico-cultural, ao citar a fundação da Vila de Nossa Senhora da Boa Viagem do Salto Grande, e seus vestígios.

A existência de uma vila colonial na cachoeira do Teotônio sempre foi vista com um pouco de descrédito pela academia, pois nenhum historiador formal (Teixeira \& Fonseca, 2006) apresentara documentação sobre tal, no entanto, a mística do nome Teotônio- é um tanto quanto óbvia para que se formulassem postulações sobre o batizado da mesma. Recentemente, Almeida (2009) e Costa (2013) trouxeram a tona importantes contribuições acerca da sistematização dos relatos dos viajantes no alto Rio Madeira.

A toponímia é a chave para o entendimento dessa narrativa colonial, o nome é uma homenagem ao primeiro europeu a se instalar de forma perene às margens da Cachoeira, Teotonio da Silva Gusmão. O português ${ }^{8}$ foi Juiz do Fórum de Mato Grosso,

\footnotetext{
${ }^{8}$ Há o mito de que Teotonio da Silva Gusmão seria o irmão menos famoso de Alexandre de Gusmão e Bartolomeu de Gusmão, o primeiro reconhecidamente o diplomata do Tratado de Madri, e o segundo o inventor do balão. No entanto, na grandiosa obra de Jaime Cortesão (2006), ao dedicar um capitulo inteiro sobre a família de Alexandre de Gusmão, não cita nenhum Teotônio. Talvez o mito seja verdadeiro e o irmão de fato é muito desconhecido.
} 
durante boa parte do segundo quartel do século XVIII, radicado em Vila Bela da Santíssima Trindade, foi incumbido pelo governador da província do Mato Grosso, Antônio Rolim de Moura, de fundar um posto fiscal fortificado na margem direita do Rio Madeira, junto à Cachoeira do Salto Grande.

As datas são um pouco confusas, mas sabe-se que em 1753, Teotônio de Gusmão enviou um pedido formal ao Rei de Portugal solicitando um substituto para seu cargo na capitania de Mato Grosso, antevendo, imagino, a tarefa de sair de Vila Bela e fundar a vila nas margens do rio Madeira. Em Novembro de 1858, o governador Rolim de Moura enviou um ofício à secretaria do Conselho Ultramarino mandando notícias acerca da "povoação de Nossa Senhora da Boa Viagem do Salto Grande". Sabemos portanto, que nesse data, o assentamento já estava fundado. A falta da ata de fundação da Vila nos leva a crer que, em algum momento, entre 1753 e 1758, Teotonio de Gusmão se instalou na margem direita da Cachoeira do Teotônio (então ainda chamada de Iaguerites), com família, escravos negros e indígenas, e alguns brancos livres.

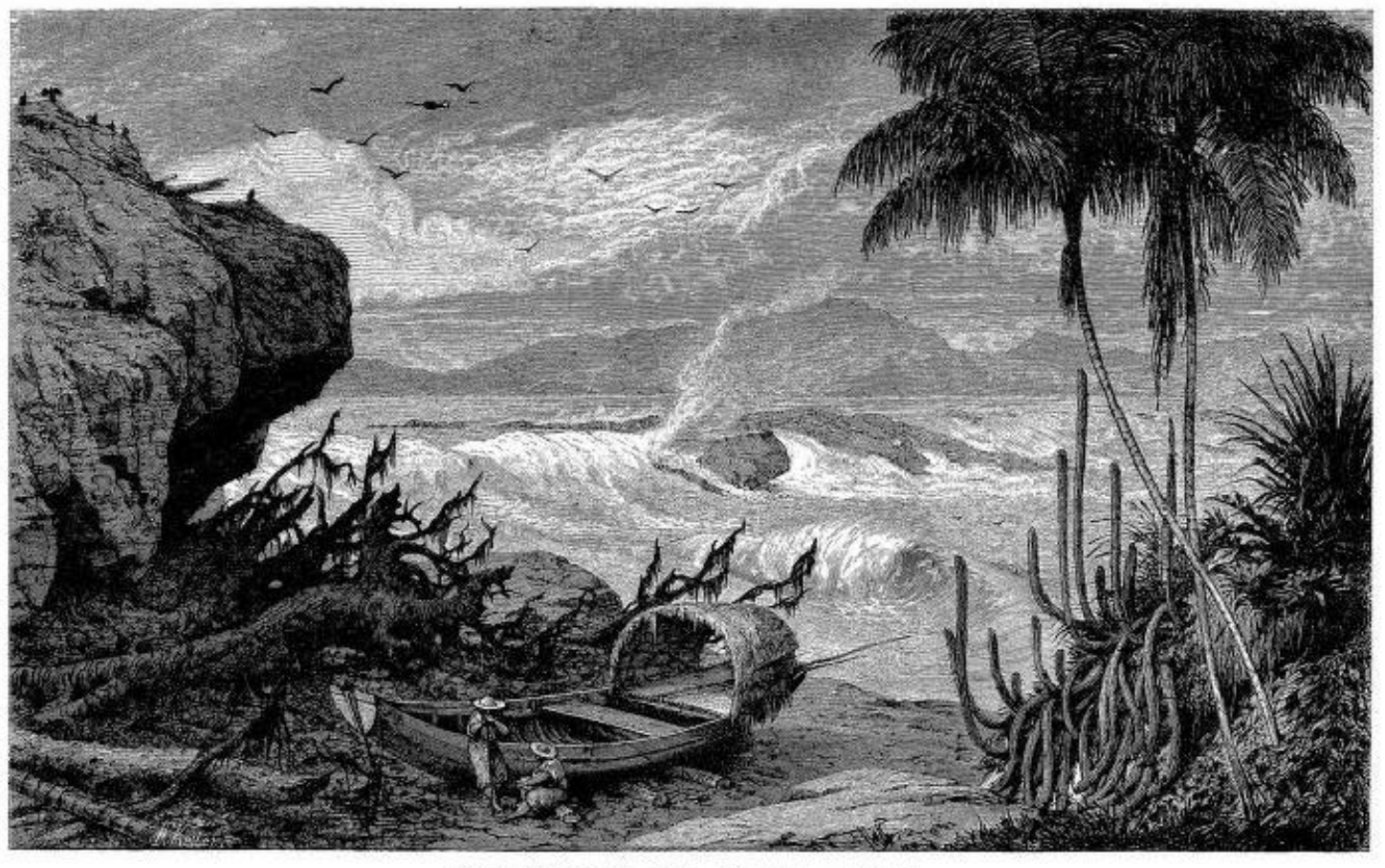

THE THEOTONIO FALL, ON THE MADEIRA.

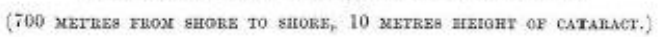

Figura 6 - Transposição da Cachoeira do Teotônio. Desenho de Franz Keller(1874) 
Também não é certo quando o assentamento foi abandonado. Teixeira e Fonseca (2006) afirmam que o mesmo não vingou devido ao intenso assédio dos índios Mura, que constantemente faziam investidas belicosas contra o arraial português. Em $1761^{9} \mathrm{o}$ Governador do Mato Grosso nomeia Teotônio de Gusmão intendente da povoação de Boa Viagem do Salto Grande, no entanto relata uma "suposta fuga para o Pará" do mesmo, sem dar maiores explicações. E em $1769^{10}$, o novo governador da província, Luis Pinto de Sousa Coutinho, em oficio ao secretário do Conselho Ultramarino, demonstra interesse em um "projeto de estabelecimento de uma nova povoação na cachoeira do Salto", possivelmente através de uma missão religiosa. Temos duas certezas portanto; houve uma ocupação colonial lusitana na margem direita da Cachoeira do Salto Grande, e, na melhor das hipóteses, durou 16 anos.

Após a tentativa infrutífera de Teotonio de Gusmão, nenhum outro relato disserta sobre qualquer assentamento às margens da Cachoeira. Antes de Keller, Alexandre Rodrigues Ferreira (2003) subiu o rio Madeira em 1787 e em nenhuma das 3 ilustrações que fez, deu destaque para qualquer conjunto de casas, muito embora seus diários não tenham sido publicados. Em 1851, em missão pela marinha norte-americana os tenentes William Lewis Herndon e Lardner Gibbon (2000), sobre a cachoeira do Teotônio, relatam

\footnotetext{
"The roaring made at intervals by the rushing of the waters over and through the rocks, sounds like distant thunder. Our little canoe is driven for safety out of the water to the land. The baggage was carried by a path on the south side to the foot of the falls. Richards went along with the first load, and remained below looking out, while I rested to see everything sent over".
}

Mais uma vez, uma caracterização das corredeiras, mas sem qualquer menção de incipiente assentamento ou suas ruínas, elemento comum de ser relatado, como quase todos o fazem, por exemplo, na cachoeira de Santo Antônio, a alguns quilômetros rio abaixo, onde desde o século XVIII foram instaladas diversas missões bem como um entreposto comercial importante no final do século XIX. Quando da construção da estrada de Ferro Madeira Mamoré, o trajeto da mesma foi planejado longe da calha do Rio Madeira, em sua maior parte, buscando as áreas de terra firme, o que rareou, de forma geral, as descrições da cachoeira do Teotônio, mesmo assim, ela continuou sendo uma

\footnotetext{
${ }^{9}$ Arquivos do Conselho Ultramarino: AHU_MATOGROSSO, cx 11, dec23
}

${ }^{10}$ Arquivos do Conselho Ultramarino: AHU_MATOGROSSO, cx 13, doc41 
referência tanto nas plantas topográficas da ferrovia, como para os primeiros registros visuais do sudoeste amazônico.

A vila que existia no local até 2011, ano da inundação, é de antiguidade desconhecida. Está ligada, certamente, a dois movimentos sócio-econômicos, um deles é a extração comercial de borracha, que teve um boom no final do século XIX, e o outro é o caminho fluvial entre as províncias do Mato Grosso e do Pará. O salto do Teotônio era um ponto de difícil transposição via fluvial, para ultrapassá-lo era necessário descer das canoas, esvaziá-las e puxá-las por terra para continuar viagem. A necessidade desse movimento, que se tornou mais regular e intenso com o comércio da borracha, pode ser a causa de origem desta moderna povoação. Na rara fotografia de 1908 do médico Suiço Dr Bauler, pode-se ver os barracões que existiam entre a cachoeira e o platô do barranco, e a existência de um pequeno trecho de trilho destinado ao auxílio da transposição da cachoeira.

\section{2- Etapa de Campo - Diferentes Perguntas, diferentes abordagens}

A Cachoeira do Teotônio, na verdade, é composta por dois sítios. Na sua margem direita, encontra-se o sítio homônimo, objeto de estudo e citado diversas vezes no decorrer do texto, mas na margem esquerda da cachoeira, Miller também identificou um sítio de dimensões medianas, com Terra Preta espessa e quantidade considerável de cerâmica, foi lhe atribuído o nome de Santa Paula ${ }^{11}$, devido à chácara que até hoje existe no local. (Anexo 4)

Apesar do levantamento inicial do Sitio Santa Paula feito por Eurico Miller, sabese que a equipe da Scientia Arqueologia realizou algumas intervenções ${ }^{12}$ no sítio, não muito intensivas, pois o mesmo, tal qual o Teotônio, não encontra-se alagado. Almeida (2013) já levanta a importância do entendimento da cachoeira como um complexo só, apesar da barreira física que é a cachoeira, o exemplo da dinâmica de relação entre as

\footnotetext{
${ }^{11}$ Miller inicialmente o nomeia de Porto Seguro. Em suas publicações, portanto, Santa Paula e Porto Seguro são o mesmo sítio arqueológico. A equipe do Museu Emilio Goeldi, na etapa de diagnóstico da UHE Santo Antônio acabou cadastrando o mesmo sítio com outro nome, daí a mudança.

${ }^{12}$ A equipe de professor da UNIR recentemente vêm desenvolvendo projeto de sítio-escola no sítio Santa Paula
} 
duas vilas que até recentemente existiam nas duas margens (as modernas vilas do Teotônio e do Santa Paula) são esclarecedores para pensar a indissociação das duas margens. No entanto, dois elementos são significativos para justificar a não intervenção no sítio: a primeira é a dificuldade logística, teríamos que cruzar o rio diariamente para escavar a outra margem, e a segunda, é o apontamento feito por Miller acerca da não existência de camadas culturais pré-cerâmicas, corroborada pela informação que obtivemos das escavações da Scientia Consultoria.

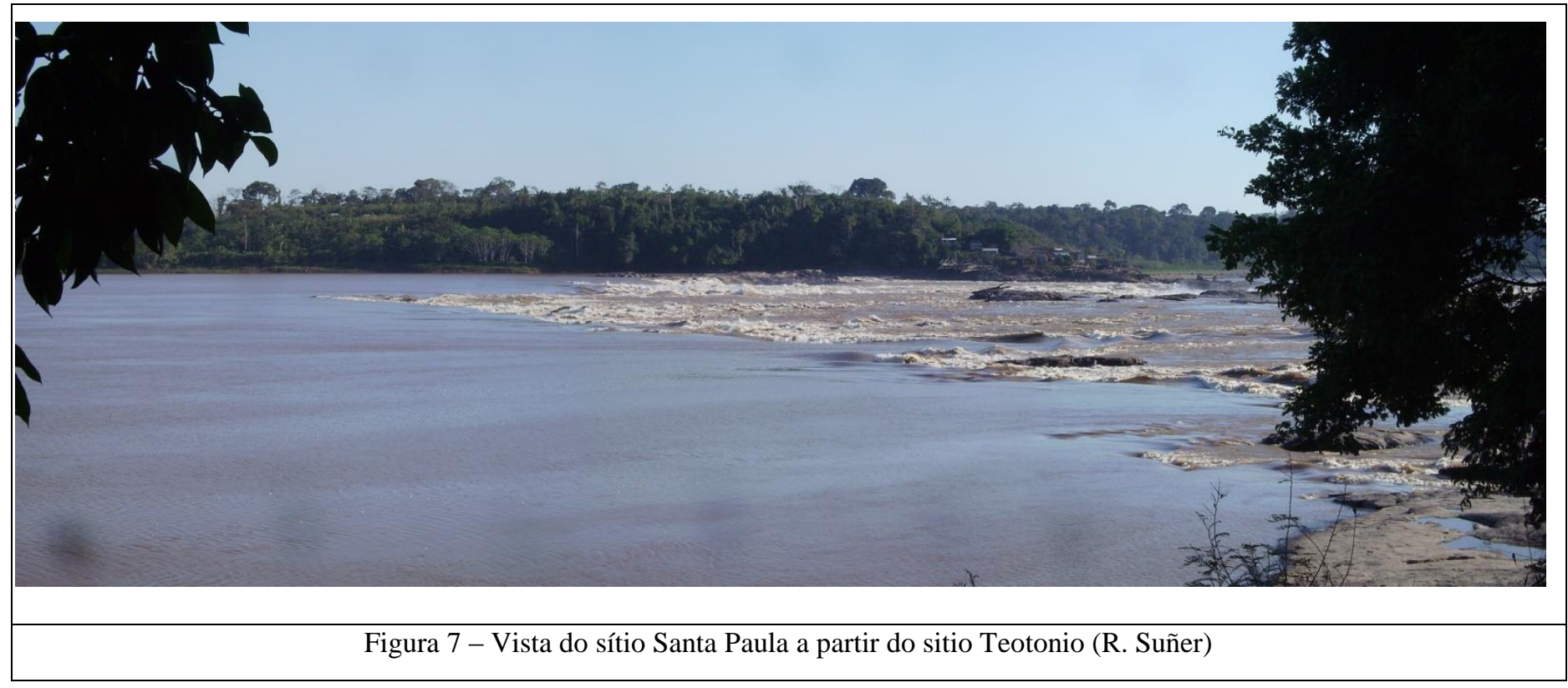

O sítio Teotônio foi identificado por Miller no final dos anos 1970, quando o mesmo era ocupado por uma fazendo de mudas de seringueira do INCRA (Simões, 1983). As escavações do mesmo revelaram um pacote de terra preta profunda, com a presença de pelo menos três camadas culturais: uma relacionada ao complexo Girau, abaixo da camada de Terra Preta; uma ocupação lítica em contexto de Terra Preta relacionada à fase Massangana, e uma ocupação ceramista associada à sub-tradição Jatuarana. Miller nunca chegou a delimitar o sítio de forma sistemática, mas estipulou uma mancha de terra preta de $1100 \mathrm{~m}$ x 300m no topo do terraço (Miller, 1978).

As atividades de Campo realizadas pelo Projeto Alto Madeira, iniciaram-se em 2011, em campanha promovida pelo então doutorando Fernando Ozório Almeida. A mítica cachoeira sempre esteve presente no imaginário dos colegas que alguns anos trabalharam na região do Alto Madeira, no entanto, o sítio homônimo só havia sofrido 
intervenções nos anos de 1970 por Eurico Miller e recentemente pela empresa Scientia Consultoria, responsável pelos estudo de impacto ambiental da UHE Santo Antônio. Tentando entender melhor o escopo tecnológico da Fase Jatuarana, Fernando Almeida decidiu realizar a última etapa escavação do seu doutoramento no mesmo lugar onde Eurico Miller, há trinta anos, havia definido a Sub-Tradição Jatuarana. Nas palavras do mesmo:

\footnotetext{
A decisão de trabalhar no sítio Teotônio foi tomada quando descobrimos (Dr. E. Neves e eu) que este sítio não seria escavado por conta do licenciamento da UHE Santo Antônio, já que estava acima da cota de inundação da hidrelétrica. Fizemos então o convite para o professor Carlos Augusto Zimpel Neto, professor de Arqueologia na Universidade Federal de Rondônia(UNIR), para a elaboração de uma parceria MAE-USP e UNIR para a escavação do sítio. Parceria esta que proporcionaria a possibilidade de alunos do curso de arqueologia realizarem atividades de campo, essenciais para a formação acadêmica dos mesmos. Estabelecida a parceria (ainda informal), foi realizado o pedido para o arqueólogo Renato Kipnis, responsável pela portaria do IPHAN para a área onde encontra-se o sítio, para que realizássemos atividades ali. (Almeida, 2013)
}

\section{Metodologia de campo}

A metodologia empregada foi a mesma utilizada pelo Projeto Amazônia Central desde 1995, descrita em inúmeras bibliografias (Neves, 2013), as técnicas empregadas permitem o estudo do sítio como unidade, formada por distintos contextos. Primeiramente, quando identificado o sítio, plotam-se linhas, orientadas cardinalmente, que guiam a execução de tradagens com boca de lobo (cavadeiras manuais) espaçadas regularmente. Dessa forma, divide-se o sítio em quadras de $1 \mathrm{~m}^{2}$, que recebem numeração de acordo com a distância de um ponto central aleatoriamente escolhido (ex. N1000 E1000; N1001 E1000, etc.) O intento principal nesse momento é ter uma noção da espacialidade horizontal e vertical da dispersão dos vestígios arqueológicos, levando em consideração a Terra Preta como elemento culturalmente constituído no espaço.

Feito o levantamento das áreas potenciais no sítio, e a partir das quadras, que formam unidades básicas para escavação, são realizadas as intervenções, normalmente em níveis artificiais de $10 \mathrm{em} 10 \mathrm{~cm}$. A sistematização dos artefatos coletados se dá através de uma numeração sequencial de Números de Proveniência (PN) para cada 
material coletado, dando preferência para os níveis artificiais, quando não há estrutura identificada.

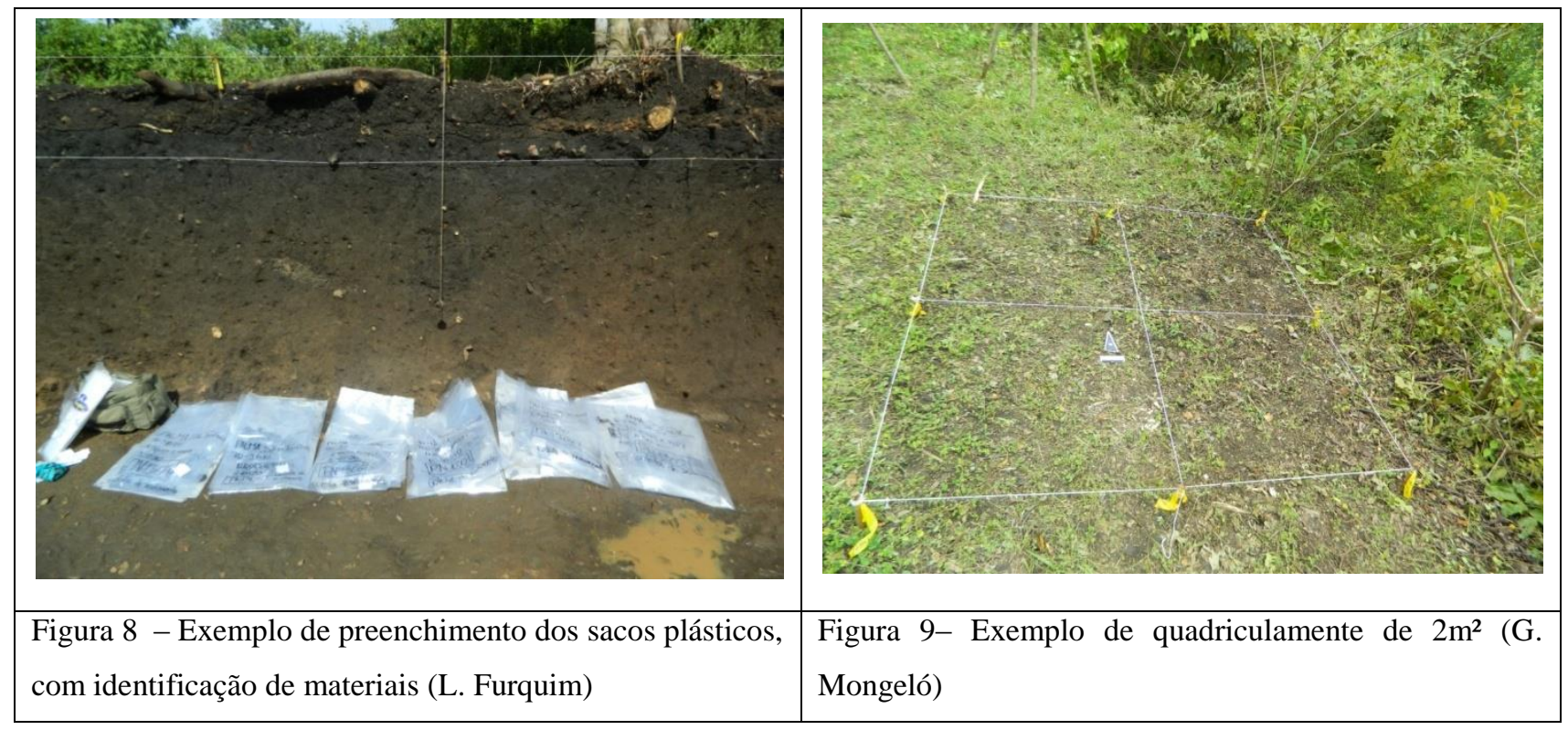

Na etapa de 2011 (Almeida, 2011), foi feito o quadriculamento do sítio, estabelecido a numeração para as quadras e realizada a delimitação parcial do sítio através das linhas de sondagens. Dessa feita, foram realizadas 55 sondagens, abertas 3 unidade de $1 \mathrm{~m}^{2}$ em regiões diferentes no sítios, e expostos $5 \mathrm{~m}$ de perfil em áreas impactadas. Esse material já foi analisado e publicado (Almeida, 2013), no entanto, é preciso retomá-lo para explicar como chegou-se à construção deste projeto.

\section{Unidade N10001 E10003}

Almeida e equipe foram a campo com o principal objetivo de entender melhor a variabilidade da cerâmica do tipo Jatuarana, e obter, na medida do possível, amostras boas de datação, de maneira que se pudesse dialogar melhor com os dados publicados por Miller. Segundo ele, o sítio Teotônio era o local com as datas mais antigas para este tipo de cerâmica.

O resultado de uma tradagem (N1000 E1000) na área central do sítio indicou um local de alto potencial, pois demonstrou que a Terra Preta ali era mais profundo do que $1 \mathrm{~m}$, e continha considerável quantidade de material cerâmico. O que a escavação da unidade N10001 E10003 nos mostrou foi um contextos mais complexo do que imaginávamos. De fato havia uma camada de Terra Preta com material Jatuarana, que ia 
da superficial até $60 \mathrm{~cm}$ de profundidade, De $60 \mathrm{~cm}$ a $100 \mathrm{~cm}$, vimos uma camada de Terra Preta onde não havia nenhum material cerâmico, apenas material lítico, e seguida por uma grande feição de solo antrópico que cortava o latossolo argiloso.

Essa ainda é a unidade mais profunda do sítio, encerrou-se com $205 \mathrm{~cm}$ de profundidade, e possui cinco camadas distintas. A primeira (I) formada por rochas lateríticas, estéril, um latossolo amarelo estéril(II), uma camada de Terra Preta sem vestígios cerâmicos e com líticos, $(\mathrm{V})$, seguida por uma ocupação ceramista em Terra Preta (VI), e por fim, a camada húmica (VII). Caracteriza-se pela presença, em sua porção $\mathrm{W}$, pela presença de uma feição profunda, delimitada por rochas lateríticas, entre $100 \mathrm{~cm}$ e $190 \mathrm{~cm}$. O sedimento de seu interior foi coletado a parte, para posterior análise. Além do doutorado do Fernando Almeida, a coluna de sedimento coletada nessa unidade foi objeto de estudo do Trabalho de Conclusão de Curso de Glenda Félix(2012)

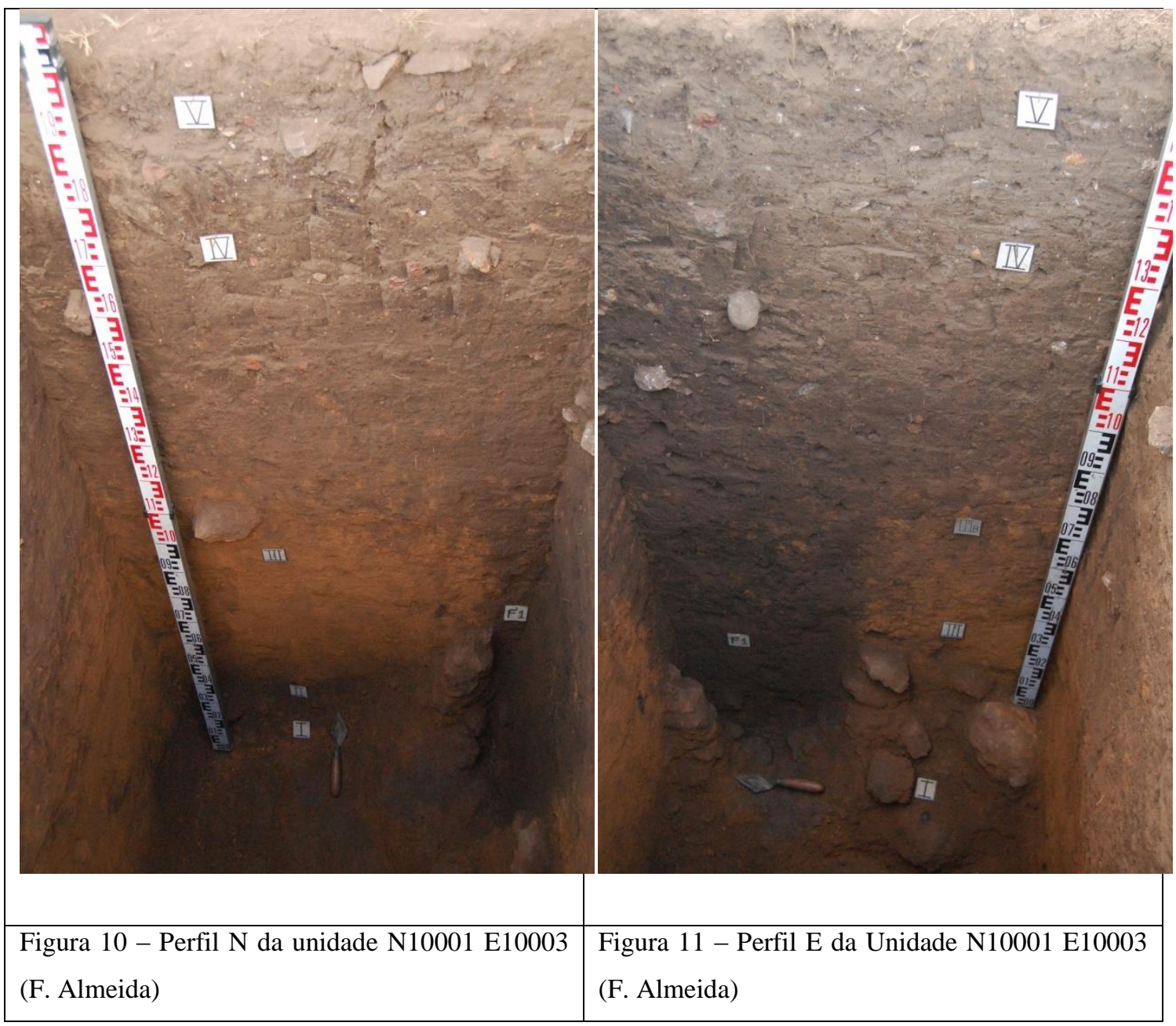


Levantamos então, a possibilidade de termos evidenciado o contexto que Miller, em diversas publicações, Chamou de Massangana, um complexo antigo, pré-cerâmico, relacionado ao Formativo. Almeida datou o topo dessa ocupação, próximo ao que seria o inicio do evento da Feição identificada, sua datação será discutida mais à frente. A análise quantitativa do material mostrou, comparando-se os líticos com a presença de material cerâmica, como a curva de fragmentos cerâmicos decresce enquanto a de fragmentos líticos aumento, enquanto se perpetua a presença de solo antrópico.

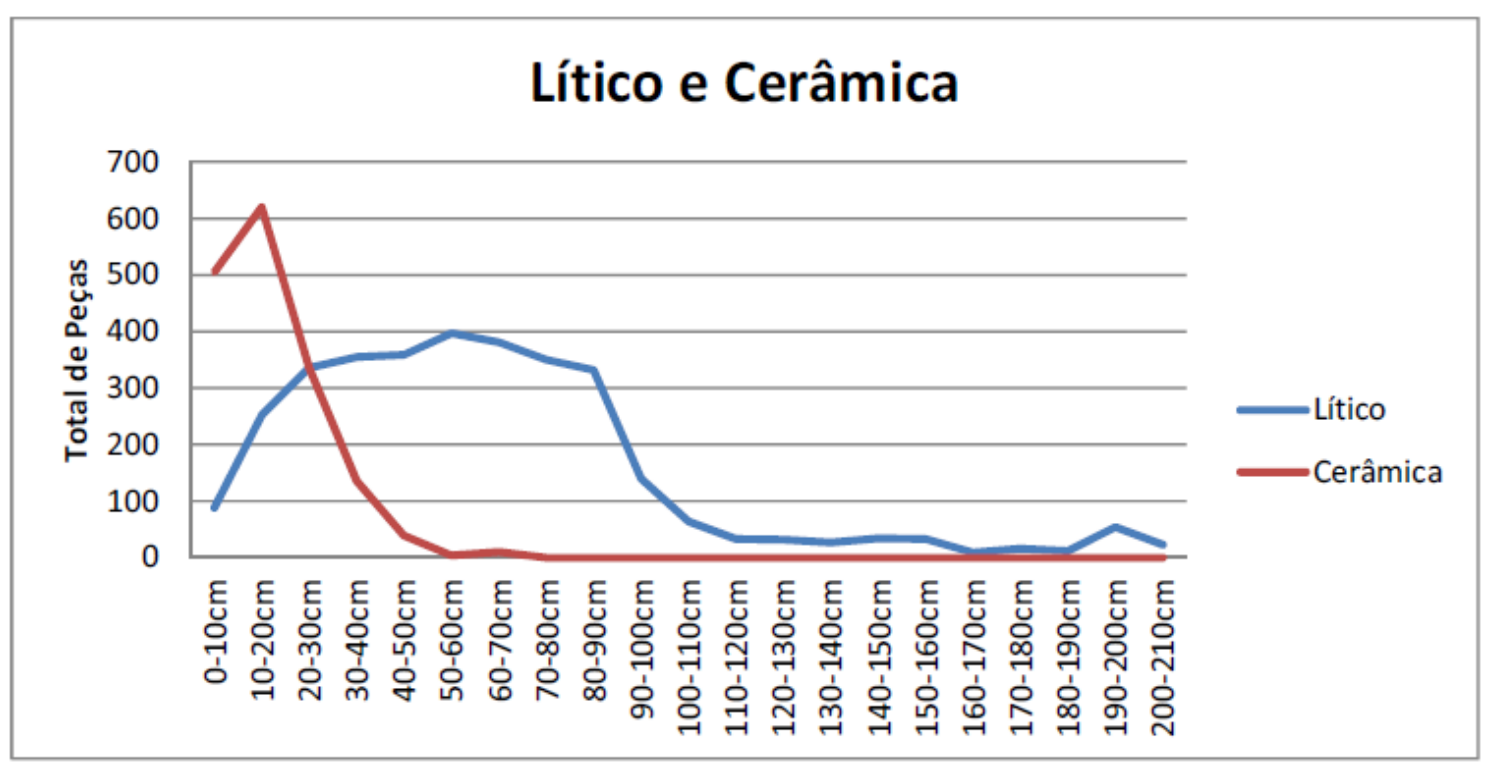

Tínhamos já dados suficientes para afirmar que se tratava de um contexto muito semelhante ao que Miller definiu como Massangana, e de fato Almeida assim o propôs na sua tese de doutoramento. A presença de um contexto claro relacionado a um processo de transformação sócio-econômica de grupos caçadores-coletores em grupos ceramistassedentários continuou sendo um debate em aberto, assim como a caracterização destas industrias líticas. São os dois elementos que propuseram a construção inicial e delinearam o estabelecimento dos objetivos desta dissertação.

\subsection{Sítio Escola Cachoeira do Teotônio - FEV/2013}

Recém ingresso no programa de Pós-Graduação em Arqueologia no MAE/USP em julho de 2012, junto ao mestrando Thiago Trindade e o orientador Dr. Eduardo Neves, foi decidido realizar mais uma etapa de campo em Rondônia, em Fevereiro de 2013. Depois de uma etapa de prospecção bem sucedida no vale do Guaporé, levantando sítios com estruturas de terra, parte do projeto de mestrado de Thiago (2012), a equipe do 
PALMA, em parceria com o Departamento de Arqueologia da UNIR, organizou o I Sítio Escola na Cachoeira do Teotônio.

As atividades de campo deram-se entre os dias 16 e 28 de fevereiro de 2013, em meio a estação de chuvas amazônicas. A estratégia desta campanha era terminar a delimitação do sítio, e eventualmente, intervir em uma área onde pudesse ter melhor entendimento do contexto pré-cerâmico. O pouco tempo e a baixa quantidade de verbas nos levou a abandonar a primeira atividade, nos concentrando na escavação de um contexto de Terra Preta sem cerâmica, com a presença de material lítico;

\section{Unidades N10003 E10004 / N10003 E10003}

Foi aberta uma área de escavação de $2 \mathrm{~m}^{2}$, próxima a unidade N10001 E 10003, de 2011, composta por quatro unidades (quadrículas). O objetivo era o de expor uma superfície ampla deste contexto pré-cerâmico, de modo que pudesse contribuir para o entendimento da disposição e dispersão dos artefatos de quartzo-lascado. Sabe-se que esta área foi altamente impactada pela construção da estrada de acesso à antiga Vila do Teotônio, evidenciada pela leiras de Terra Preta presentes nas proximidades, o que indica grande movimentação de Terra. De qualquer forma, a presença da F1 na Unidade N10001 E10003 comprova a estabilidade e preservação dos contextos mais profundos.

As quatro unidades contíguas abertas foram escavadas por níveis artificiais de 10 em $10 \mathrm{~cm}$, tal qual a metodologia aplicada em 2011. Devido a grande quantidade de chuvas no mês de Fevereiro, as quadrículas N10003 E10004 e N10004 e N10004.deixaram de ser escavadas em $60 \mathrm{~cm}$ e $40 \mathrm{~cm}$ de profundidade respectivamente, principalmente pela incapacidade de peneirar o sedimento que tornara-se altamente argiloso devido à absorção de água.

As quadrículas N10003 E10003 e N10004 E10003, na porção S da unidade, foram escavadas até $110 \mathrm{~cm}$, sendo encerradas devido a grande quantidade de rochas lateríticas. Foi evidenciado material arqueológico até os níveis mais profundos, embora em quantidade diminuta. Vale ressaltar, em relação a essas unidades que:

1- Apesar de estarem a 1 m de distância da quadricula N10001 E10003, apresentam composição estratigráfica completamente diferente, especula-se que seja devido à presença de F1 na mesma 
2- Embora tenham diferença de profundidade, a composição das camadas arqueológicas, é parecida, nas unidades N10003 E10003 e N10004 E10003, ocorre uma camada lateritica com material (II), uma camada de Terra Preta sem cerâmica com lítico (V), Terra Preta com cerâmica(VI) e o antrópico moderno (VIII).

3- Material cerâmico muito fragmentado, com poucas peças diagnósticas, muitas bordas de lábio arredondado

4- Aparente homogeneidade na coloração da Terra Preta, apesar da mudança de material arqueológico

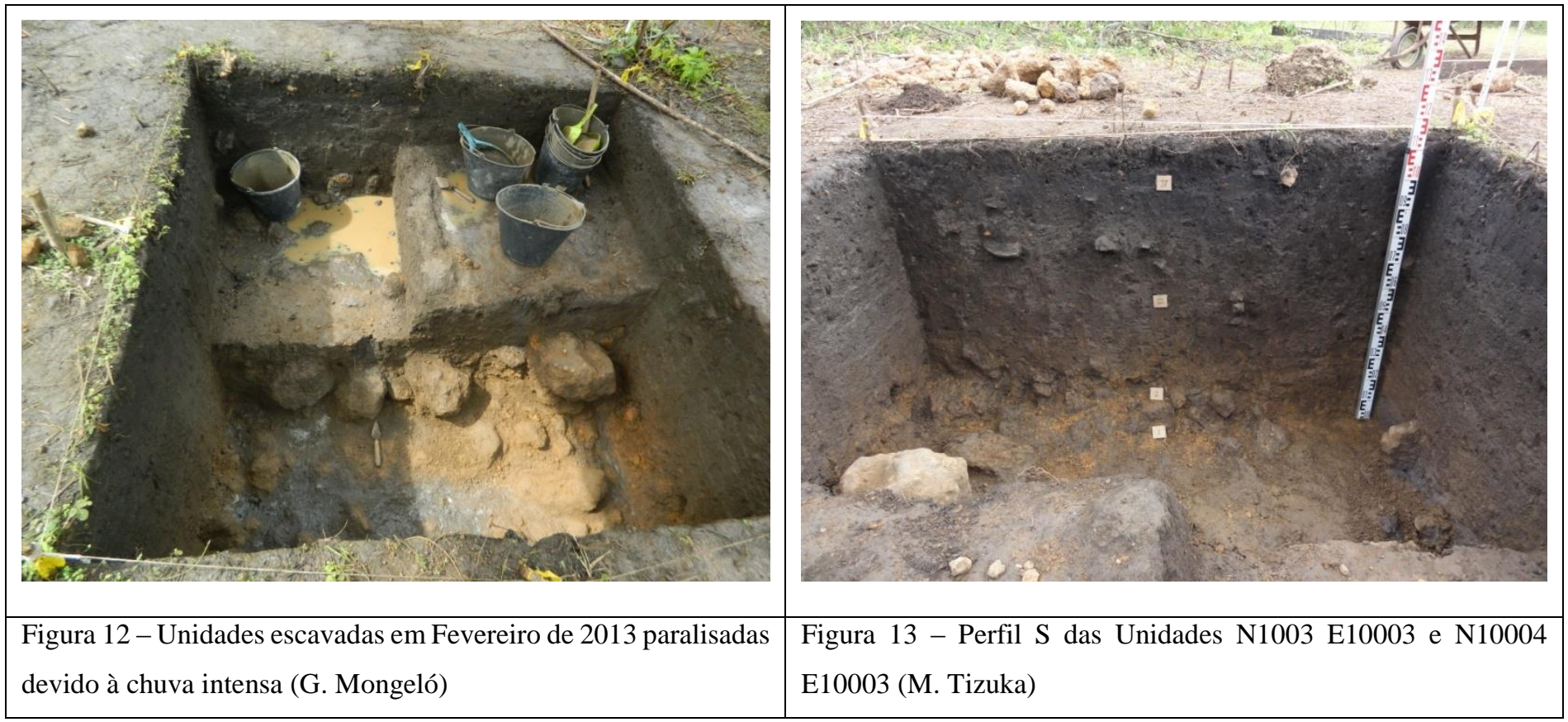

\section{Perfil Perfil Leste da Linha E 9987}

O uso de maquinário pesado em escavações arqueológicas sempre esteve no imaginário dos integrantes do PALMA, as imagens de grandes superfícies amplas nas Guianas e no Amapá constituíam uma sensação de satisfação e temor, maquinas de 1 ton ao lado de delicadas estruturas de cerâmica. Como bem mostra o mapa do sítio feito em 2011 (Anexo 13) a estrada de acesso a antiga Cachoeira corta o sítio em sua parte central, deixando em suas margens, um barranco paralelo formado pela construção da mesma, quando esta começa a descer em direção à margem do rio. Nessa etapa, para melhor entender as camadas estratigráficas que compõe o sítio, decidiu-se utilizar um desses 
cortes do barranco, feitos anteriormente pela construção da estrada, alocá-lo no grid, e retificar, expondo assim um longo perfil, e para isso, utilizou-se de uma pá mecânica.

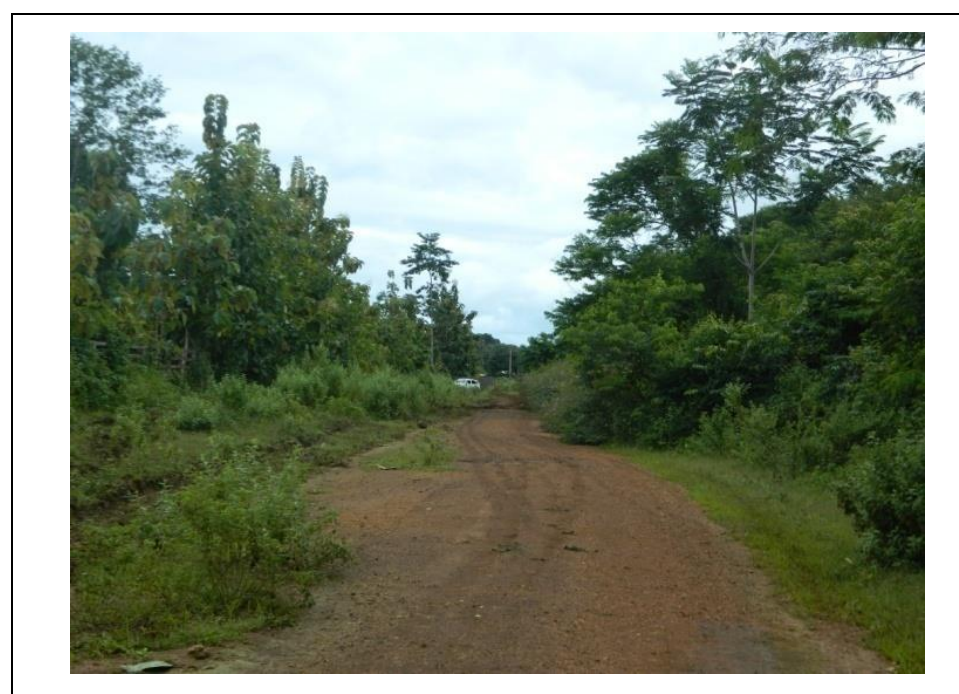

Figura 14 - Estrada de acesso à antiga Cachoeira do Teotônio (G. Mongeló)

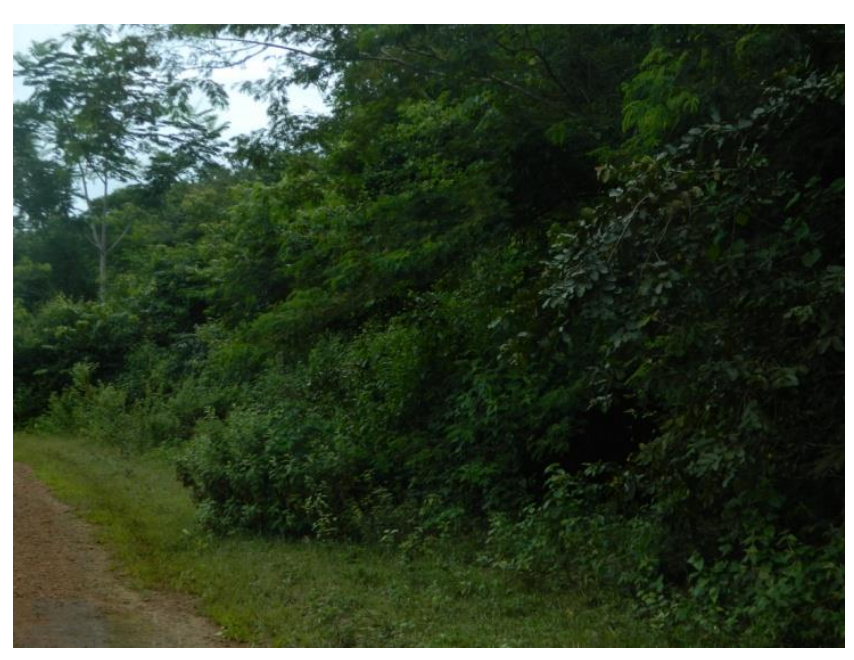

Figura 15- Barranco da estrada antes de ser exposto e retificado (G. Mongeló)

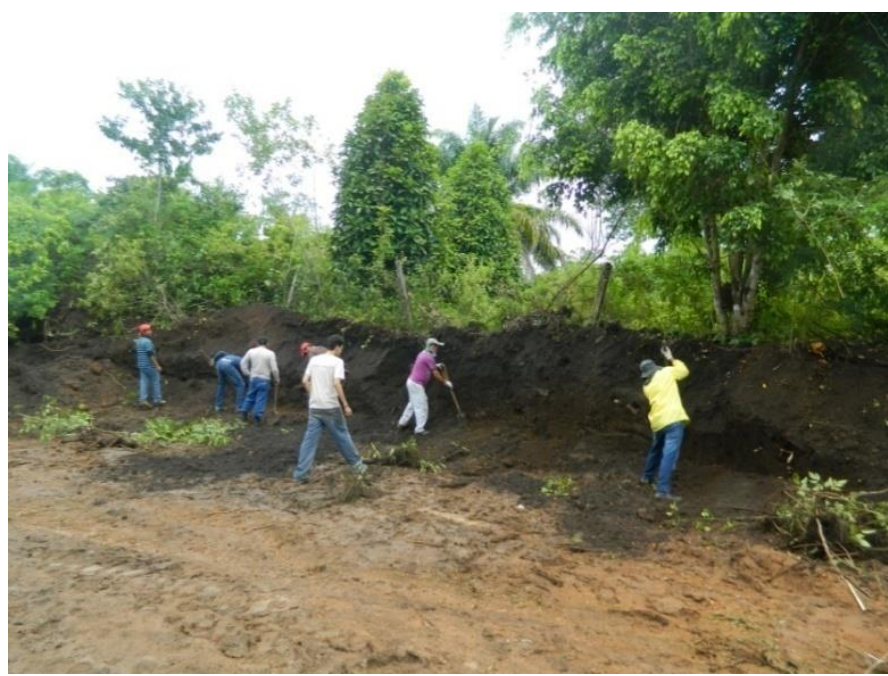

Figura 17 - Retificação do perfil exposto (T. Trindade)
Figura 16 - Acompanhamento do processo de limpeza do perfil com a pá mecânica (T. Trindade)

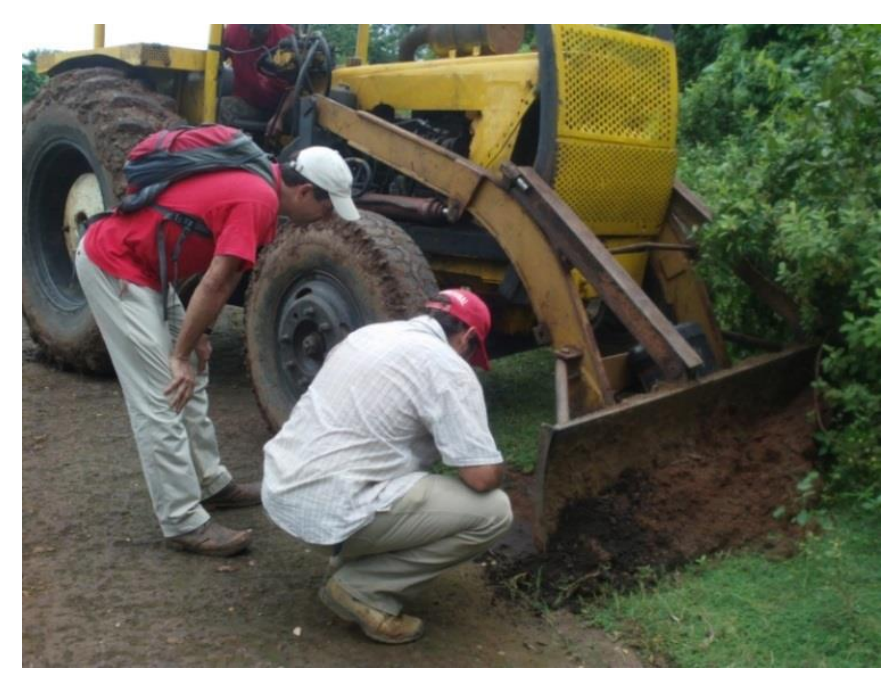




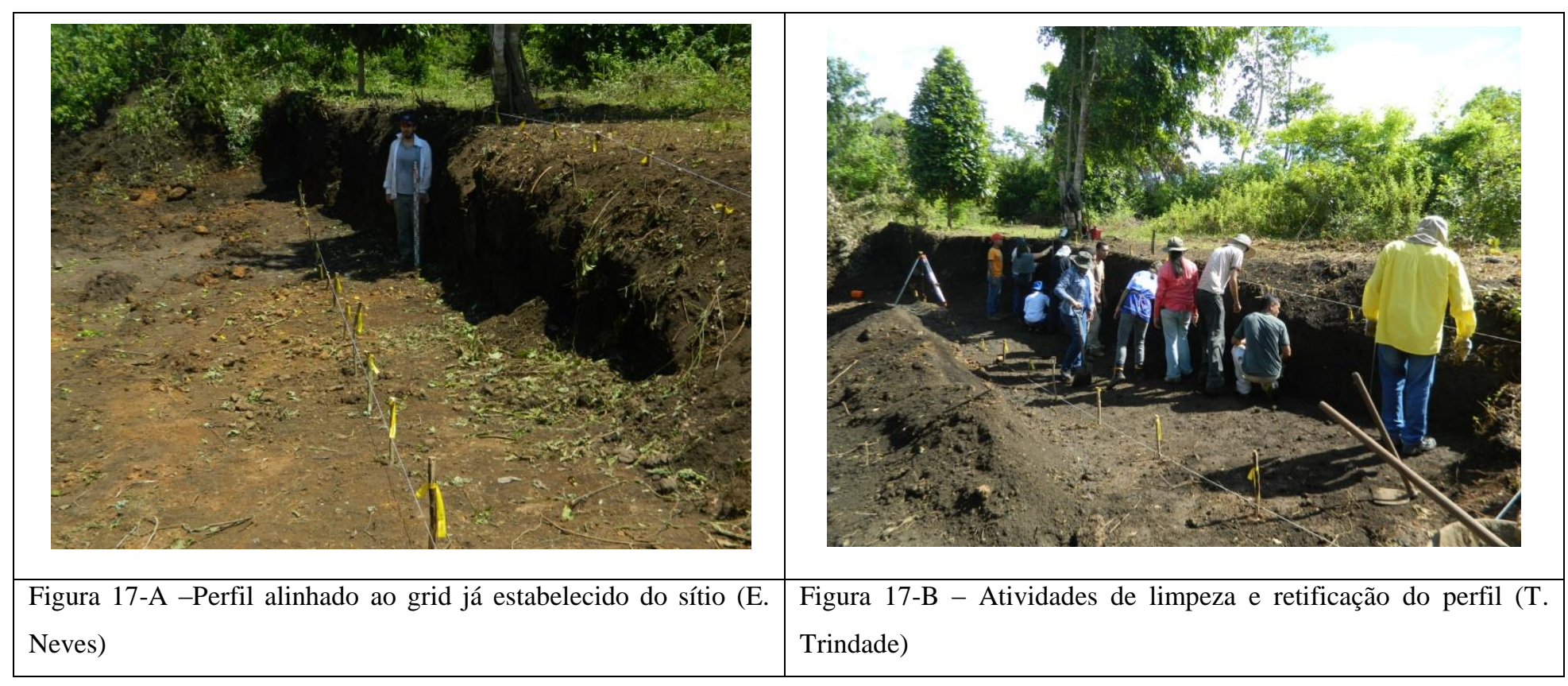

A utilização da pá mecânica nesse contexto demonstra a aplicabilidade de diferentes técnicas para obtenção de resultados a partir de diferentes objetivos. Com o pouco tempo à disposição, e a grande incidência pluviométrica (o que poderia causar danos consideráveis a um barranco exposto por muito tempo), a retificação do barranco, realizada de forma rápida, porém controlada e monitorada, com o uso de maquinário pesado, mostrou-se uma alternativa versátil ao contexto presente.

De forma prática, a pá mecânica retirou o excesso de sedimento (de forma controlada, deve-se salientar) acumulado às margens da estrada por anos de antropização recente, limpando ao mesmo tempo a vegetação de capoeira que se formou, resultando no perfil abaixo: 


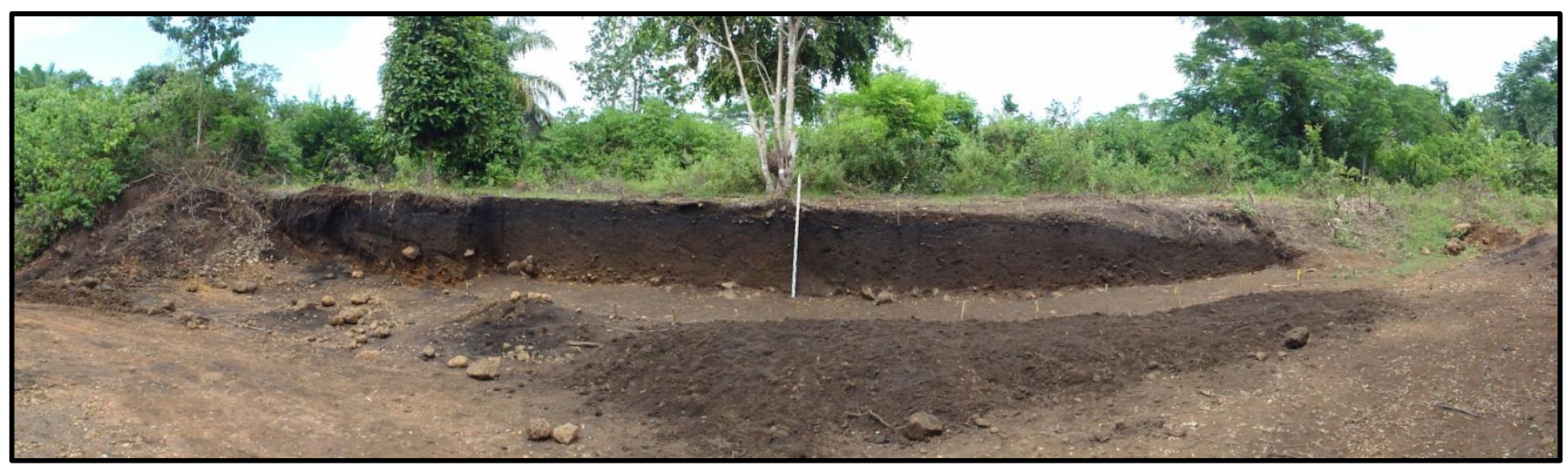

Figura 20 - Panorâmica dos perfis das unidade N10030 E9987 / N10045 E9987

Perfil Leste da Linha E 9987 (D. Pelegrini)

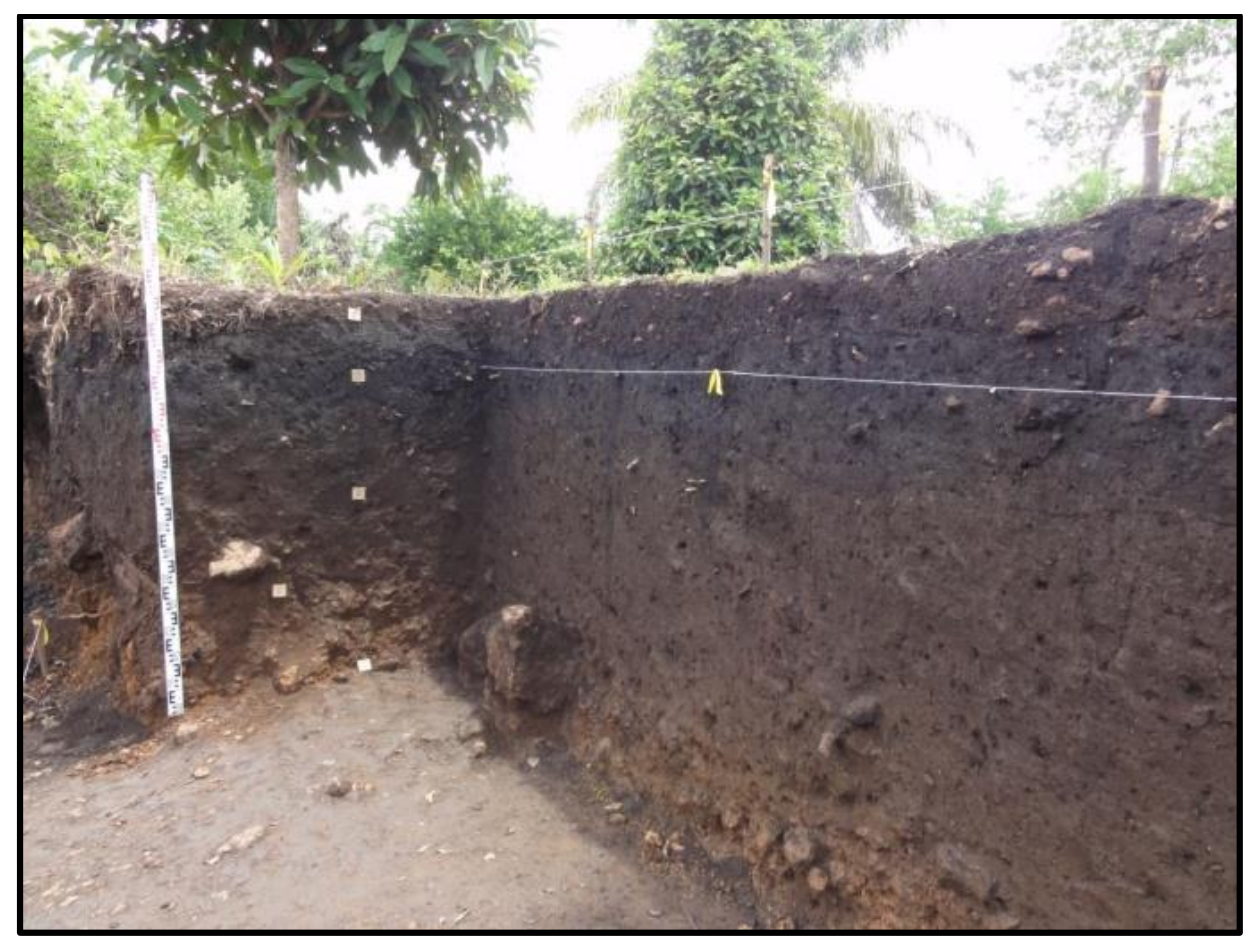

Figura 21 - Perfil N da Unidade N 10030 E9987 (M. Tizuka)

Após a retirada do sedimento remexido por mais de 300 anos de ocupação moderna, e coletado o material diagnóstico, foi feito o alinhamento do perfil para encaixálo no grid já existente, sendo feito a retificação do mesmo e posteriormente o desenho de 15 metros de perfil face $\mathrm{W}$ e 1 metro de perfil face $\mathrm{N}$.

Além do desenho dos 16 m, e da coleta de material cerâmico e lítico diagnóstico, e carvão para datação, foi feira uma coluna de sedimento, de $50 \times 25 \mathrm{~cm}$, na face Norte da 
Unidade N10045 E9987, material já flotado e que encontra-se analisado (cap. 4). A pesquisadora do ArqueoTrop, Michelle Tizuka, retirou amostras para palinologia, micromorfologia e tubos para datação de solo.

A partir da análise do perfil exposto, somado com os dados então feitos nas escavações, ao final desta campanha, pode-se inferir que:

1- Há de fato uma ocupação pré-ceramista, com datas que remontam o século XI a.C., com artefatos líticos lascados em matriz de quartzo presentes em solo antropizado. No perfil retificado, tal ocupação possui mais de $50 \mathrm{~cm}$ de espessura;

2- A estratigrafia das camadas de ocupação não é homogênea para todo o sítio, seja por intervenções modernas, ou por usos diferentes do espaço, camadas presentes em uma área do sitio não necessariamente aparecem em outro;

3- Há uma camada, profunda, de laterita friável, com percolações de solo antrópico, pouca incidência de material lítico e com carvões estruturados. Leva-nos a pensar que as primeiras ocupações humanas à beira da cachoeira foram justamente sobre esse solo laterítico, e que o sedimento que o sobrepõe é, portanto antrópico;

4- Dessa forma, mesmo que com apenas duas datas, especula-se que esse processo de antropização do meio ambiente, refletido na configuração da Terra Preta, seja bastante antigo, e talvez, não esteja relacionado ao advento da tecnologia cerâmica/sedentarização 


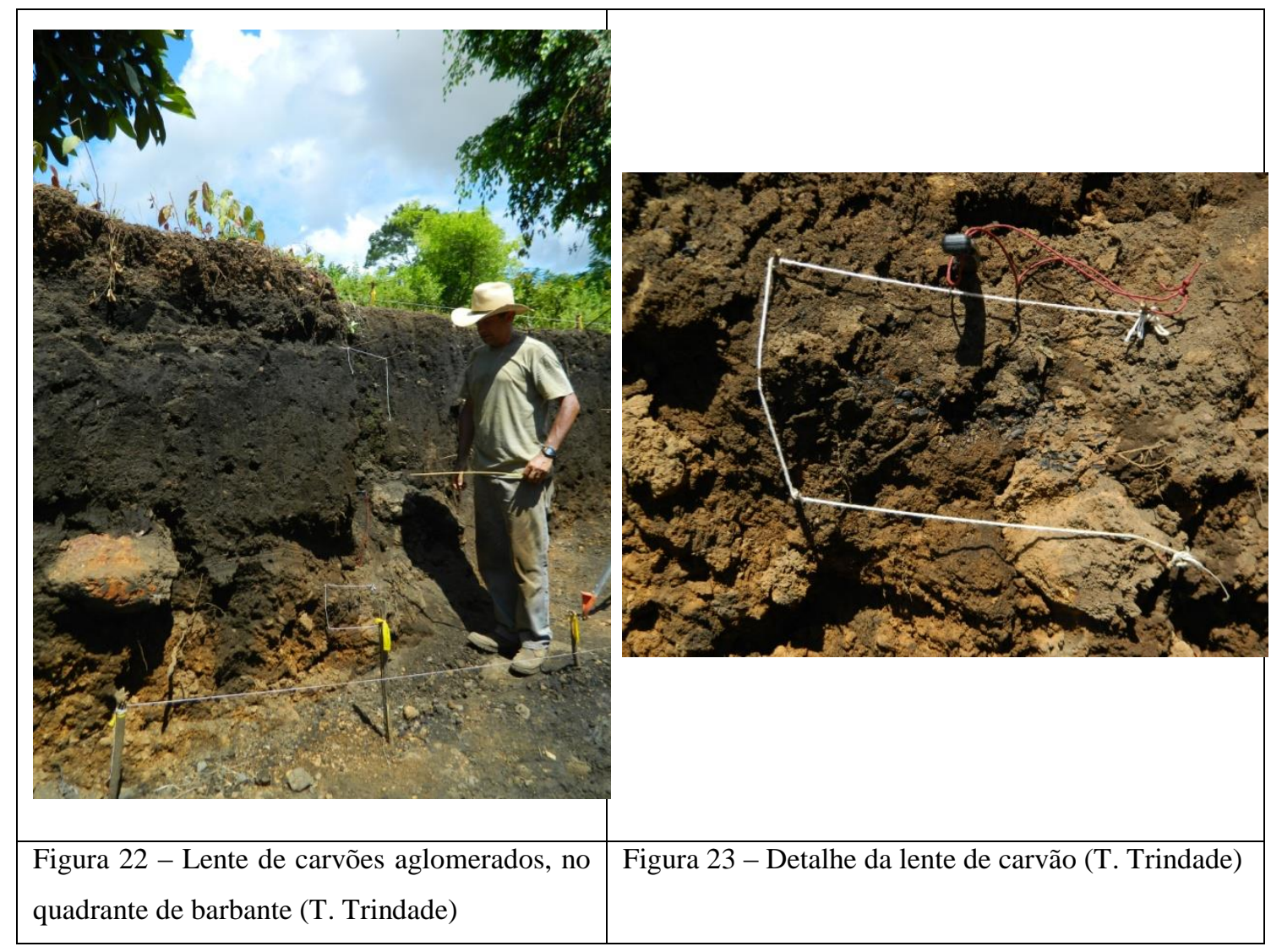

\section{4 - II Sítio Escola Cachoeira do Teotônio}

Fazer arqueologia no meio acadêmico possibilita a conjunção de diversos interesses motrizes para a realização das atividades relacionadas a tal empenho. A terceira campanha de escavação do sítio Cachoeira do Teotônio, mais uma vez realizada em conjunto com o Departamento de Arqueologia da UNIR, como estágio supervisionado para os alunos da $1^{\text {a }}$ turma de arqueologia, foi resultado da demanda de diversos pesquisadores e instituições, e possibilitou o entendimento da ocupação deste local de forma mais sistêmica.

Mesmo que o objetivo principal desta campanha tenha sido a delimitação espacial do sítio arqueológico, foi dada ênfase também ao processo pedagógico dos alunos então presentes, possibilitando que os mesmos pudessem acompanhar diversas técnicas de escavação e registro. Sendo assim, procederam-se atividades de: 
1- Abertura de picadas para locação do grid e malha de sondagens, foram mais de1000m de picada;

2- Delimitação do sítio através de tradagens realizadas com cavadeira boca-delobo, distas 20m uma da outro, totalizaram-se 114 sondagens;

3- Escavação controlada de 5 unidade de $1 \mathrm{~m}^{2}$ cada;

4- Retirada de 2 urnas em área impactada pela estrada de acesso à antiga Cachoeira;

5- Caminhamento em área plana desmatada e coleta sistemática de fragmentos cerâmicos diagnósticos;

6- Topografia com aparelho Estação Total.

Esta etapa de campo durou 23 dias, contou com 6 pesquisadores de São Paulo, 25 alunos do curso de arqueologia da UNIR, coordenados pelo prof. Carlos Zimpel, além das valiosas contribuições dos professores Eduardo Bespalez, Silvana Suze, e dos pesquisadores do ArqueTrop Francisco Pugliese e Michelle Tizuka.

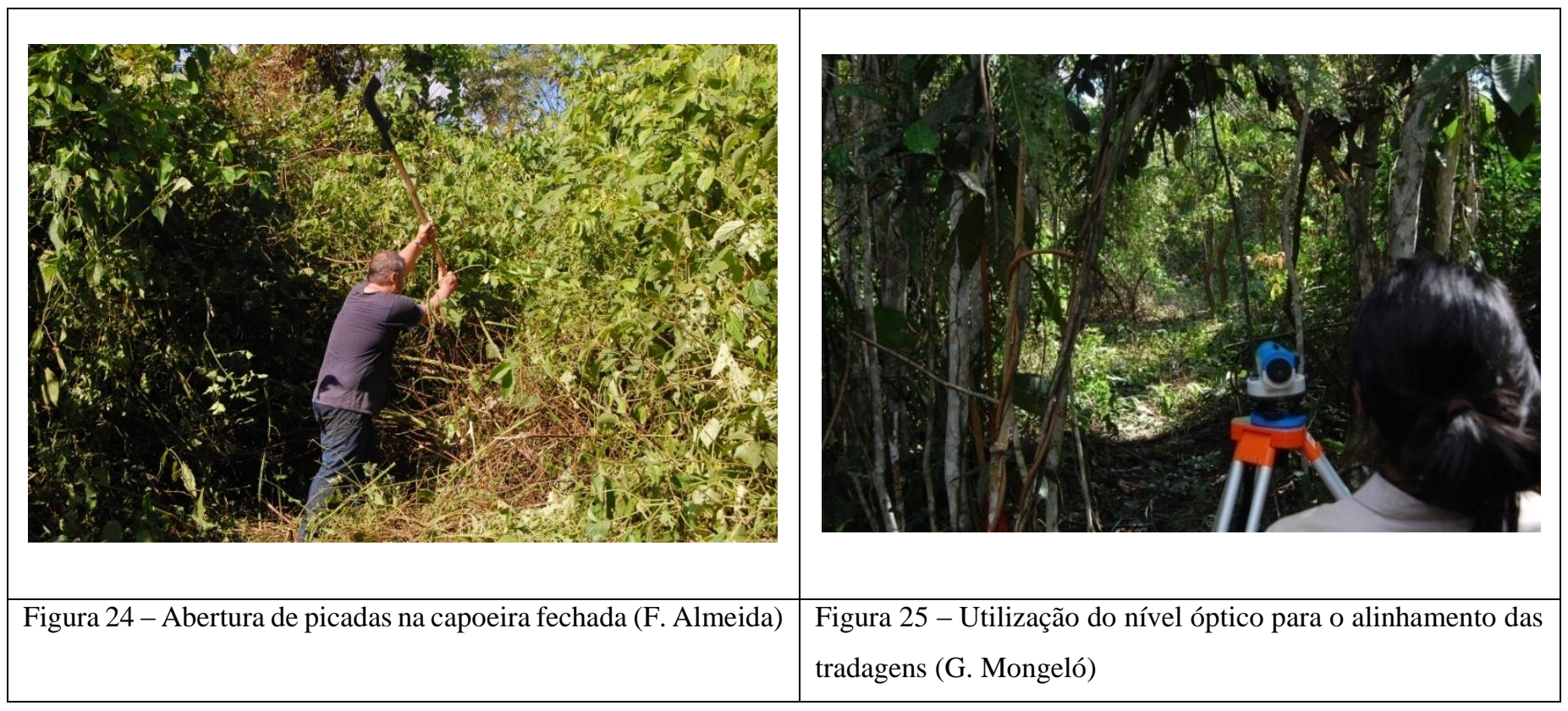




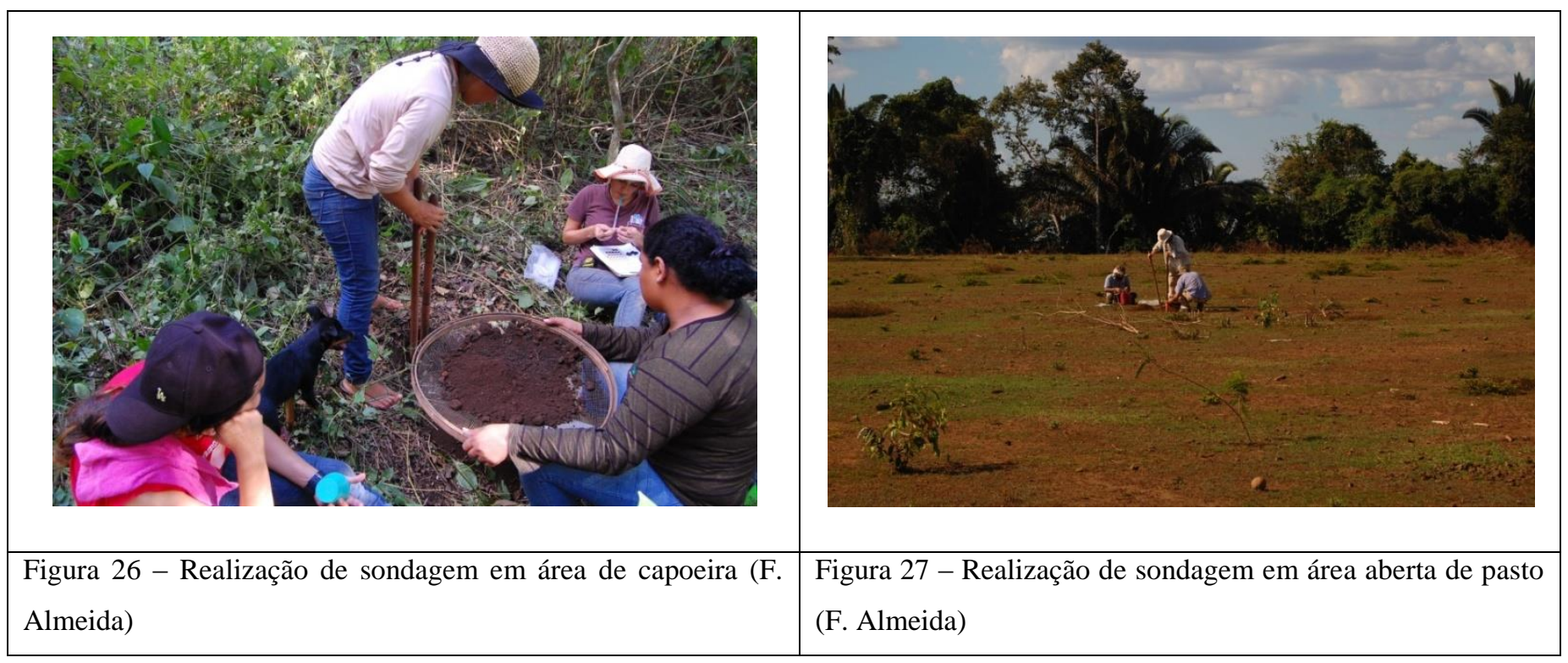

O resultado das sondagens realizadas foi processado diretamente no campo. Ao final de cada dia era atualizado o croqui de dispersão de material no sitio, possibilitando que os pesquisadores pudessem pensar em estratégias de abordagem mais sistemáticas durante as próprias atividades de delimitação. Tanto que, das 5 unidade de $1 \mathrm{~m}^{2}$ abertas, duas foram motivadas pela retirada de duas urnas que encontravam-se em risco, e as outras três foram orientadas por questionamentos levantados a partir dos dados das tradagens.

Segue sumária descrição das unidades escavadas: 


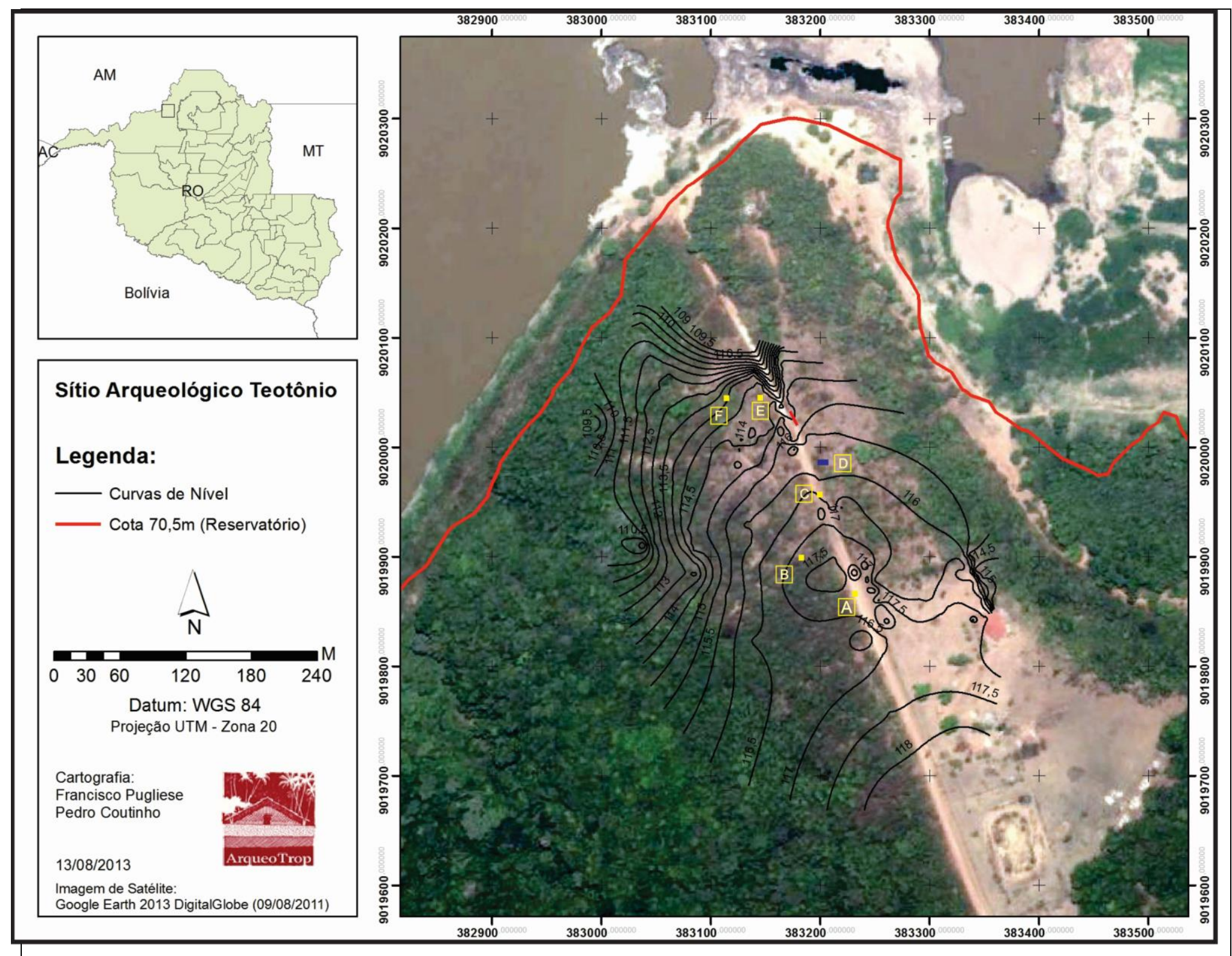

Figura 28 - Mapa do Sítio Tetônio, com as curvas de nível da topografia em preto, linha da cota do reservatório em vermelho, e as intervenções das campanhas de Fevereiro e Julho de 2013. A linha laranja, no centro do mapa, representa o perfil de 15m exposto, os pontos roxos (D) representam as unidade N10003 E10004/ N10003 E10003. Os demais pontos representam: A= unidade N9882 E10022; B = unidade N9920 E9940; C = unidade N9947 E 10005; E= unidade N10041 E9955; e F= unidade N10041 E9824

\section{Unidade N9920 E9940 (B)}

Unidade aberta devido a dados levantados em sondagem próxima, com grande quantidade de material cerâmico nos níveis superficiais. Dista-se 50m a oeste da estrada que corta o sítio, recoberta de vegetação do tipo capoeira fechada, em área até então pouco inexplorada do sítio. 


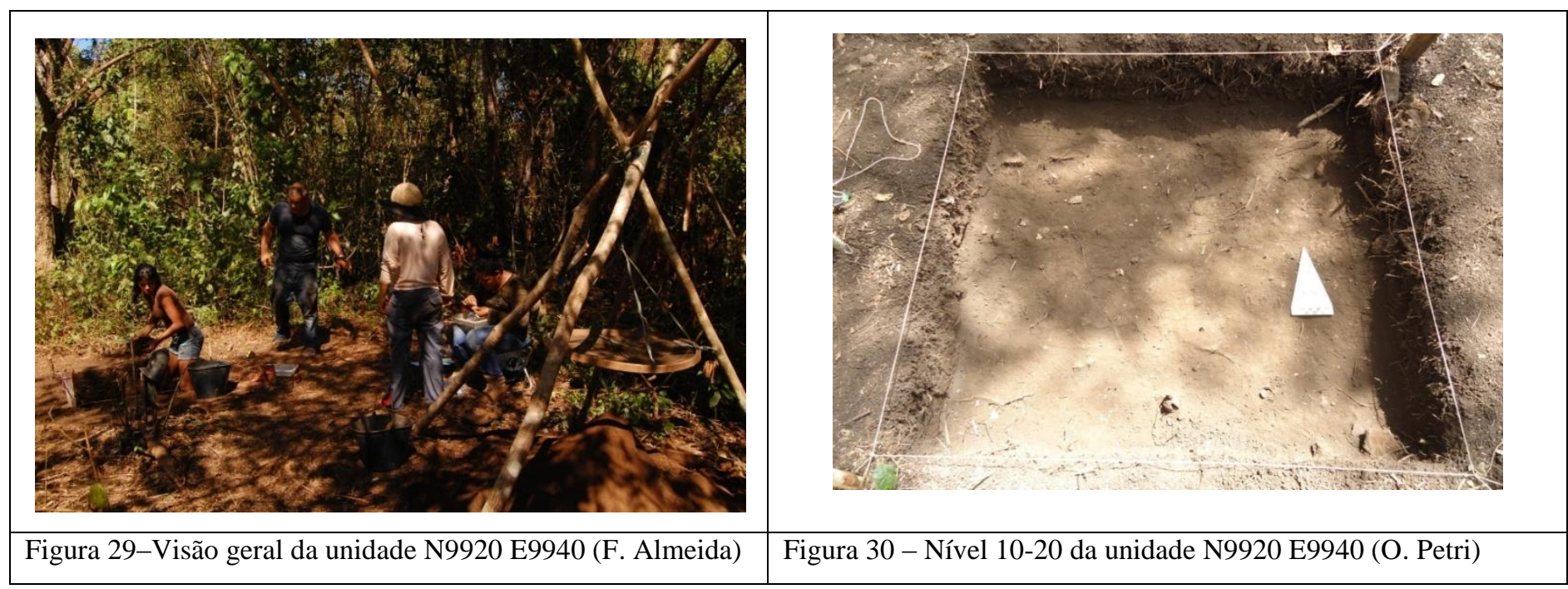

A unidade encerrou-se com $110 \mathrm{~cm}$ de profundidade, e confirmou as informações obtidas na tradagem, uma grande porcentagem de material cerâmico concentrada entre os níveis 0-30, com a presença de bordas diagnósticas e paredes decoradas, fragmentos provavelmente relacionados à fase Jatuarana. A quantidade de material arqueológico diminui drasticamente a partir dos $30 \mathrm{~cm}$, no entanto, não há informação suficiente para afirmar a existência de uma camada pré-cerâmica. A partir dos $60 \mathrm{~cm}$, o solo torna-se mais claro, acompanhado por grandes quantidades de rochas lateríticas, e tal qual em outros áreas do sítio, não há nível estéril, sendo evidenciados fragmentos de quartzo lascado junto a camada de rocha profunda.

\section{Unidade N10041 E 9824 (F)}

Unidade de $1 \mathrm{~m}^{2}$ aberta em área periférica do sítio, no seu limite Oeste, próximo ao barranco que leva as margens do Rio Madeira. Encontra na mesma linha, em direção a W, da unidade N10041 E 9955. Encontra-se recoberta por mata secundária, do tipo capoeira fechada.

As informações levantadas pela sondagem realizada próxima (N10040 E9820) mostraram a seguinte estratigrafia, sendo encerrada a $90 \mathrm{~cm}$ devido a presença de concreções lateríticas.

\begin{tabular}{|l|l|}
\hline Profundidade $(\mathrm{cm})$ & Materiais Arqueológicos (quantidade) \\
\hline
\end{tabular}




\begin{tabular}{|l|l|}
\hline $0-20 \mathrm{~cm}$ & Sem material \\
\hline $20-40 \mathrm{~cm}$ & Cerâmica $=4$ \\
\hline $40-60 \mathrm{~cm}$ & $\begin{array}{l}\text { Cerâmica }=2 \\
\text { Lítico }=29\end{array}$ \\
\hline $60-80 \mathrm{~cm}$ & Lítico $=39$ \\
\hline $80-90 \mathrm{~cm}$ & Lítico $=6$ \\
\hline
\end{tabular}

Figura 31 - Gráfico de incidência de vestígios arqueológicos da tradagemN100040 E9824

Dessa forma, ao escavar a área próxima da tradagem, esperava-se encontrar um contexto de solo antrópico antigo, profundo, de característica pré-cerâmica, com adensamento de lascas de quarzto em relação à profundidade. No entanto, com o andar das atividades de escavação da unidade, percebeu-se de fato uma diminuição por volta dos $40 \mathrm{~cm}$ da pouca quantidade de fragmentos cerâmicos que estavam sendo evidenciados nos níveis anteriores, porém não foi visível a predominância de artefatos líticos nas camadas mais profundas.

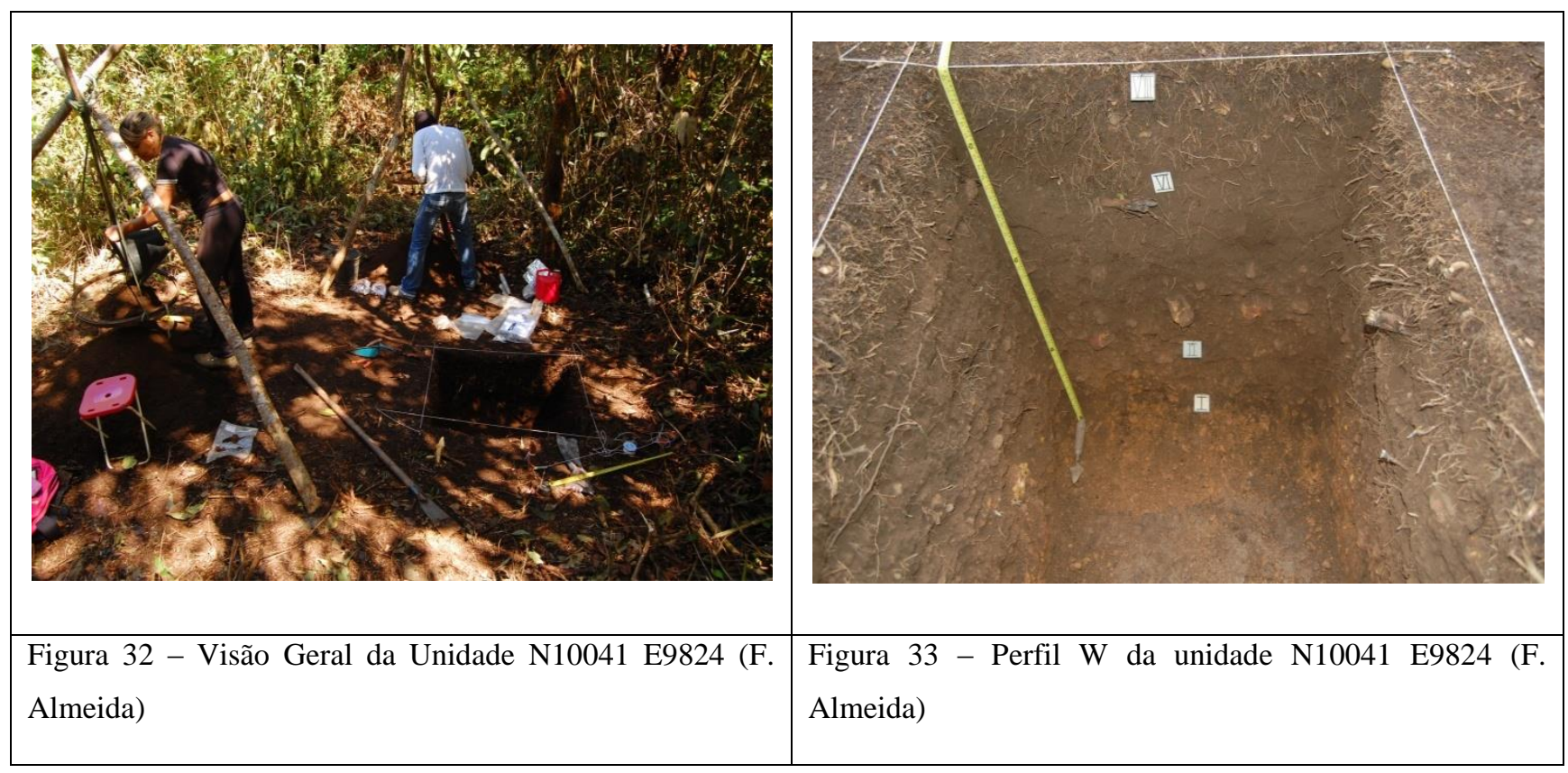

Apesar das expectativas levantadas pela análise da sondagem, não foi possível identificar uma camada pré-cerâmica na unidade N10041 E9842, com 60 cm de profundidade, a presença de artefatos arqueológicos na camada era quase nula, e a quantidade de rochas de laterita friável aumentou gradativamente. A principal hipótese é que a unidade se encontre em área periférica do sítio, muito próxima ao barranco. 


\section{Unidade N 10041 E9955 (E)}

Eurico Miller quando escavou o sítio Cachoeira do Teotônio relata ter evidenciado uma camada de $2 \mathrm{~m}$ de Terra Preta, sem interrupções, iniciada esta diretamente na rocha laterítica (Miller, 1992), no entanto, não encontramos, nas duas primeiras etapas de escavação, um contexto semelhante.

Quando da realização das linhas de tradagens para delimitação, deparamo-nos com uma área, composta de aproximadamente $60 \mathrm{~m}^{2}$, em que as sondagens encerravamse a $120 \mathrm{~cm}$ devido a incapacidade de continuar escavando dado o tamanho da ferramenta, e com quantidade anormal de fragmentos cerâmico, de médio a grande porte.

A unidade N10041 E9955 foi aberta no centro dessa área de $60 \mathrm{~m}^{2}$, antigo roçado do Sr. Fernandes, onde ainda podia-se ver vestígios de mangueiras de irrigação da plantação. A intenção de escavar uma unidade neste local foi:

1- Confirmar a informação descrita por Miller de estratigrafias profundas e complexas de Terra Preta;

2- Entender melhor a dispersão horizontal do material cerâmico no sitio;

3- Refinar a seriação cerâmica proposta por Almeida (2013), uma vez que os dados das tradagens indicavam ser uma área com grande quantidade de fragmentos diagnósticos, não só Polícromos/Jatuarana;

4- Buscar contextos pré-cerâmicos em área de solo antrópico. 


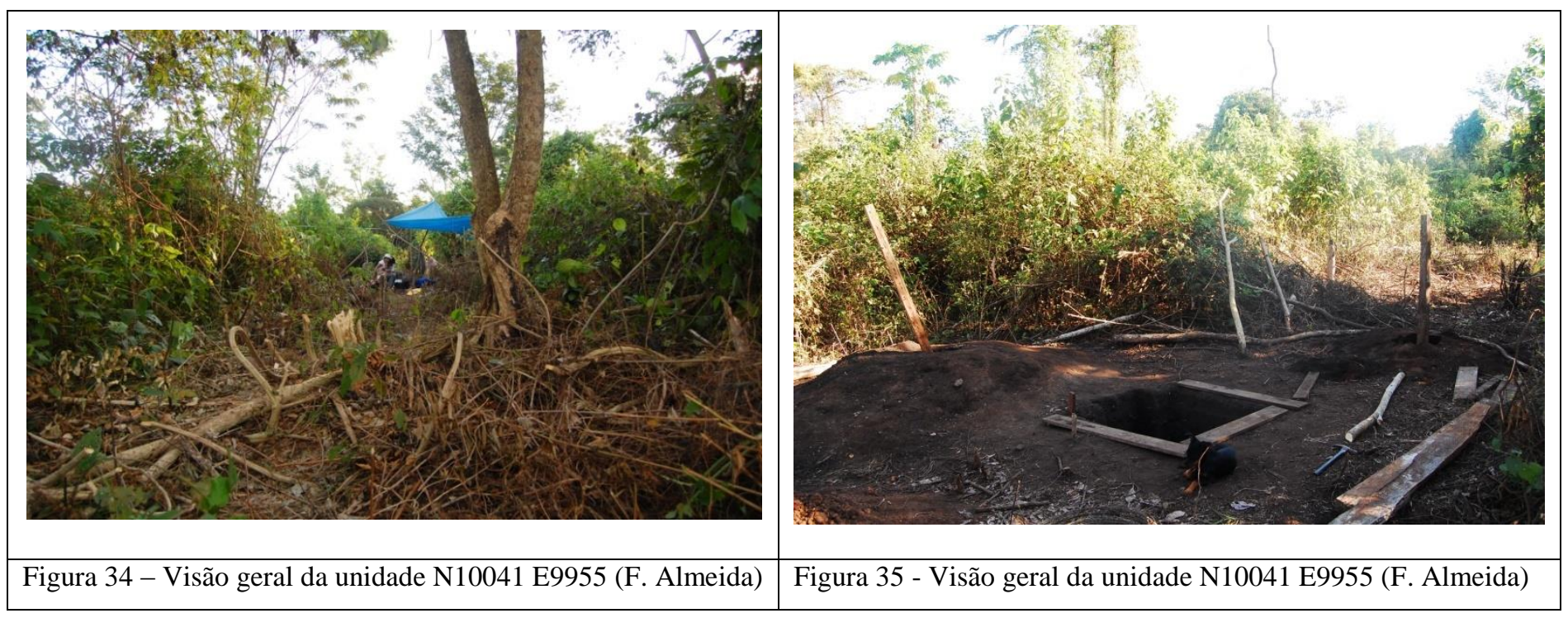

A unidade N10041 E 9955 apresentou um pacote arqueológico composto de Terra Preta de $290 \mathrm{~cm}$ ininterrupto. No entanto, é possível identificar algumas camadas de adensamento cerâmico, principalmente entre os níveis $30-60 \mathrm{~cm}$, caracterizado por fragmentos com decoração pintada policroma, bordas expandidas, e grande quantidade de carvão; grandes aglomerações de cerâmica nesse nível foram coletadas com PNs diferentes. No nível 90-140cm, foi evidenciada outra camada com grande quantidade de fragmentos cerâmicos, de tamanho grande, a maior parte disposto horizontalmente no solo. Estes possuíam características de decoração relacionadas à Tradição Barrancóide, como acanalados, incisões em linhas duplas, flanges mesiais e bordas recortadas. Nesse nível, foi coletado também grande quantidade de carvão e vestígios faunísticos.

Vale ressaltar que não é de todo absurdo uma ocupação ceramista com características associadas à Tradição Barrancóide, tanto Almeida quando Zuse (2014), nos estudos dos sítios impactados pela construção da UHE Santo Antônio, levantam a possibilidade de fases ceramistas ligadas à tal tradição no calha do Alto Rio Madeira.

A partir dos $250 \mathrm{~cm}$ de profundidade, houve um decréscimo vertiginoso da quantidade de material arqueológico, permanecendo assim até seu término. No entanto, não houve aparente modificação no sedimento, que continuou característico de Terra Preta antropogênica. A unidade deu-se por encerrada aos $300 \mathrm{~cm}$ devido á alta concreção rochosa laterítica, de coloração amarela, que tomou conta da base da unidade, impossibilitando a escavação. 


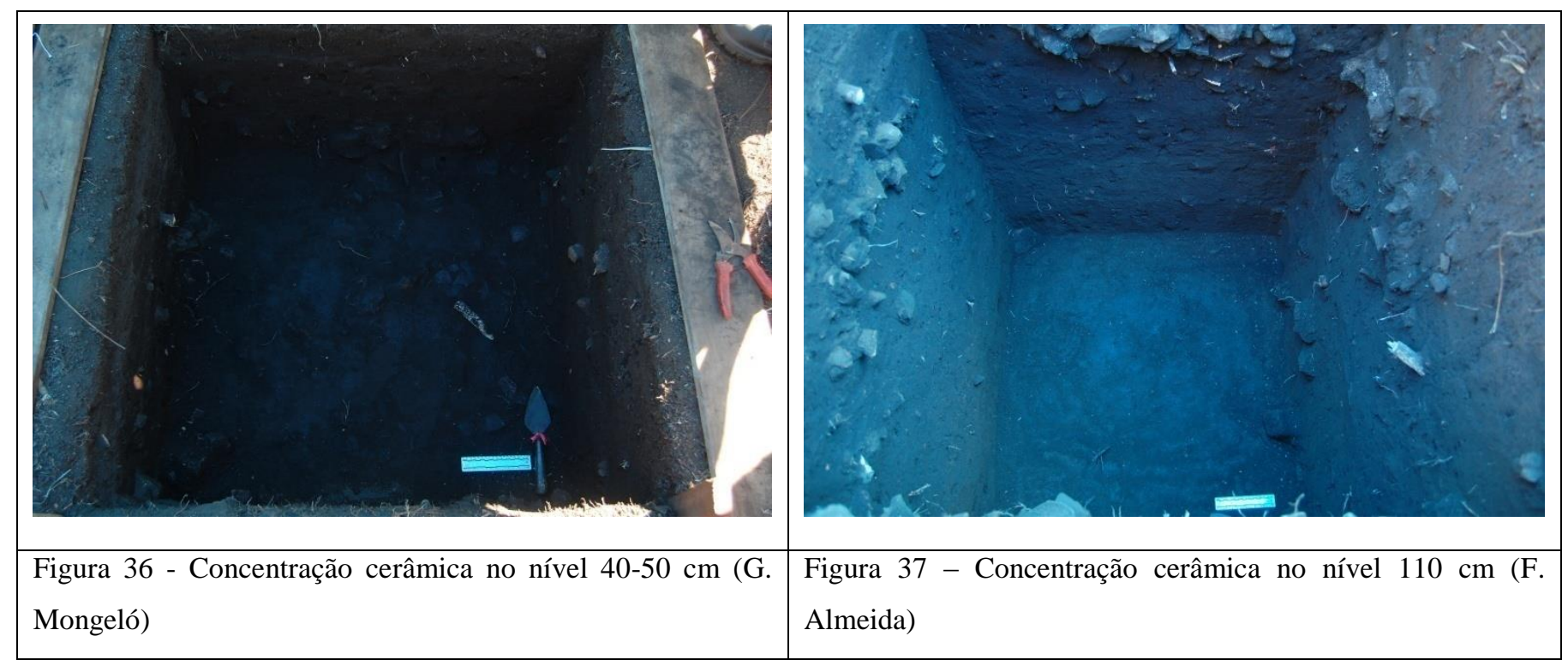

Ao final da escavação, infere-se que:

1- De fato, há uma área melhor preservada do sítio, não sabe-se ainda se este contexto de $3 \mathrm{~m}$ de Terra Preta era presente em toda área do sítio, mas certamente ele se estendia muito mais do que a então presente. As sucessivas (e recorrentes até hoje) retiradas de Terra Preta por moradores de Porto Velho para a venda na capital explicam uma parte desse processo

2- Como levantado por Almeida (2013), há mais do que uma ocupação cerâmica, além da Jatuarana/Polícroma, de difícil filiação cultural, pois apresenta características tecno-tipológicas de diversos horizontes estilísticos. No entanto, a partir da escavação desta unidade, imagina-se haver uma ocupação duradoura e persistente anterior, constatação que necessita de melhores análises do material coletado.

3- A topografia do sítio mostra que, apesar das sabidas retiradas de Terra Preta, esta área do sítio encontra-se em igual altura do platô sobre o qual se dispõe os vestígios, eliminado a hipótese de ser este quadrado de $60 \mathrm{~m}^{2}$ um montículo de grandes proporções, como os vistos na Amazônia Central (Castro, 2009) Sendo assim, especula-se que a complexa estratigrafia de $3 \mathrm{~m}$ de altura, composta de sedimento antropizado, seja formado por sucessivas (e talvez antigas) ocupações humanas. Necessita-se de datações para confirmar tal hipótese. 


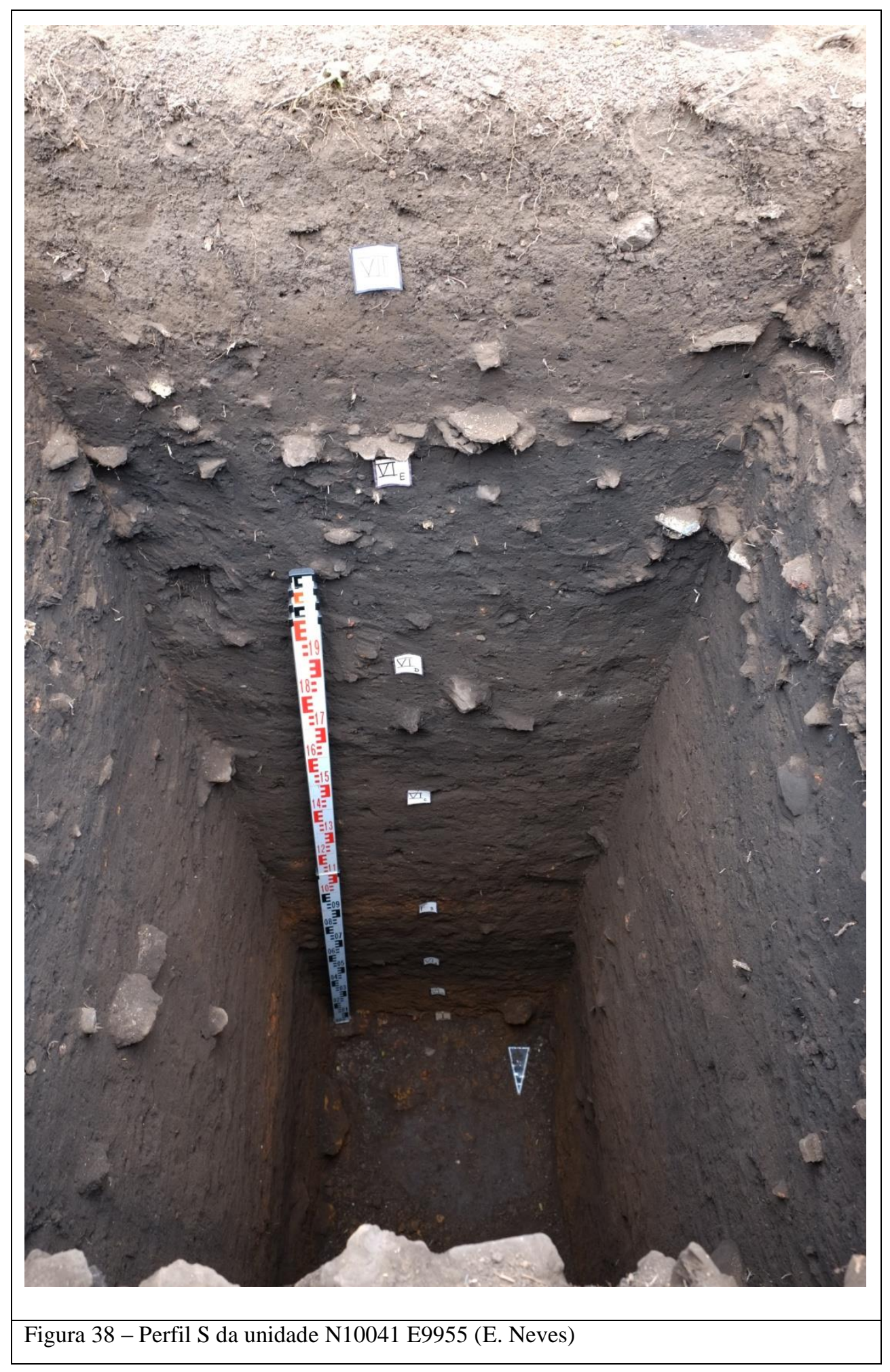

\section{Unidade N9947 E10005 (C)}

Esta unidade foi plotada justamente sobre as bordas de uma estrutura de cerâmica que aparentava ser uma vasilha enterrada, encontra-se sobre a estrada que ligava a antiga Cachoeira do Teotônio, área com grande impacto moderno. $\mathrm{O}$ objetivo principal desta 
escavação era a retirada da vasilha, uma vez que tínhamos poucos exemplares de bordas reconstituíveis para formar conjuntos (tipos) morfológicos.

Devido à alta compactação do solo, a escavação se deu através de instrumentos pesados (ferro-de-cova e picareta), uma vez que pouquíssimo material foi evidenciado. A estratégia inicial para a retirada da vasilha inteira era a de escavar a unidade, deixando um pedestal para posteriormente retirá-la com uma camada de proteção de sedimento ao seu redor; no entanto, a camada de solo antrópico não ultrapassou os $30 \mathrm{~cm}$ de profundidade, chegando a escavação na base superior da rocha laterítica.

A impossibilidade de retirar a vasilha em pedestal devido à presença de laterita por toda a unidade nos levou à necessidade de desmontar a estrutura no local, retirando controladamente os fragmentos cerâmicos e coletando o sedimento interno de forma integral.

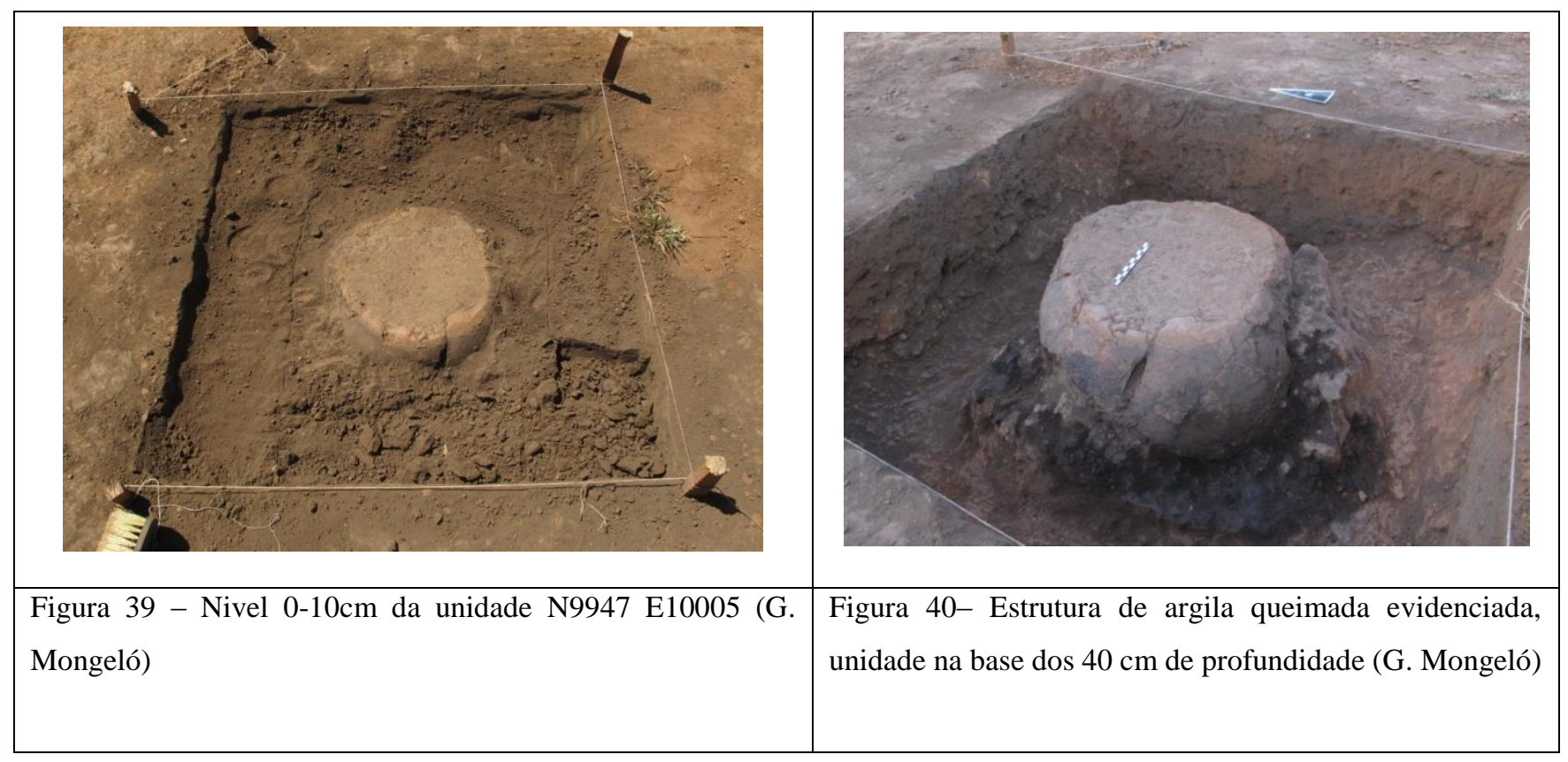

O esvaziamento da estrutura (que recebeu PN separado) revelou esta não ser uma vasilha emborcada (hipótese inicial), mas sim um "tampão" de argila queimada in loco, fechando uma feição escavada na laterita, como uma argamassa de terracota. A falta de alisamento interno na cerâmica, somada à queima mal feita em sua parte superior e uma camada de fuligem espessa em sua parte exterior nos dá indícios de que de fato não seja uma vasilha fabricada em um momento anterior à sua deposição no local atual.

O sedimento do interior da estrutura foi esvaziado de $10 \mathrm{em} 10 \mathrm{~cm}$, e coletado inteiramente, sem peneiramento. Foi possível perceber a grande quantidade de carvões e 
de fragmentos de ossos, no entanto, não pode-se ainda afirmar se trata-se de uma estrutura funerária.

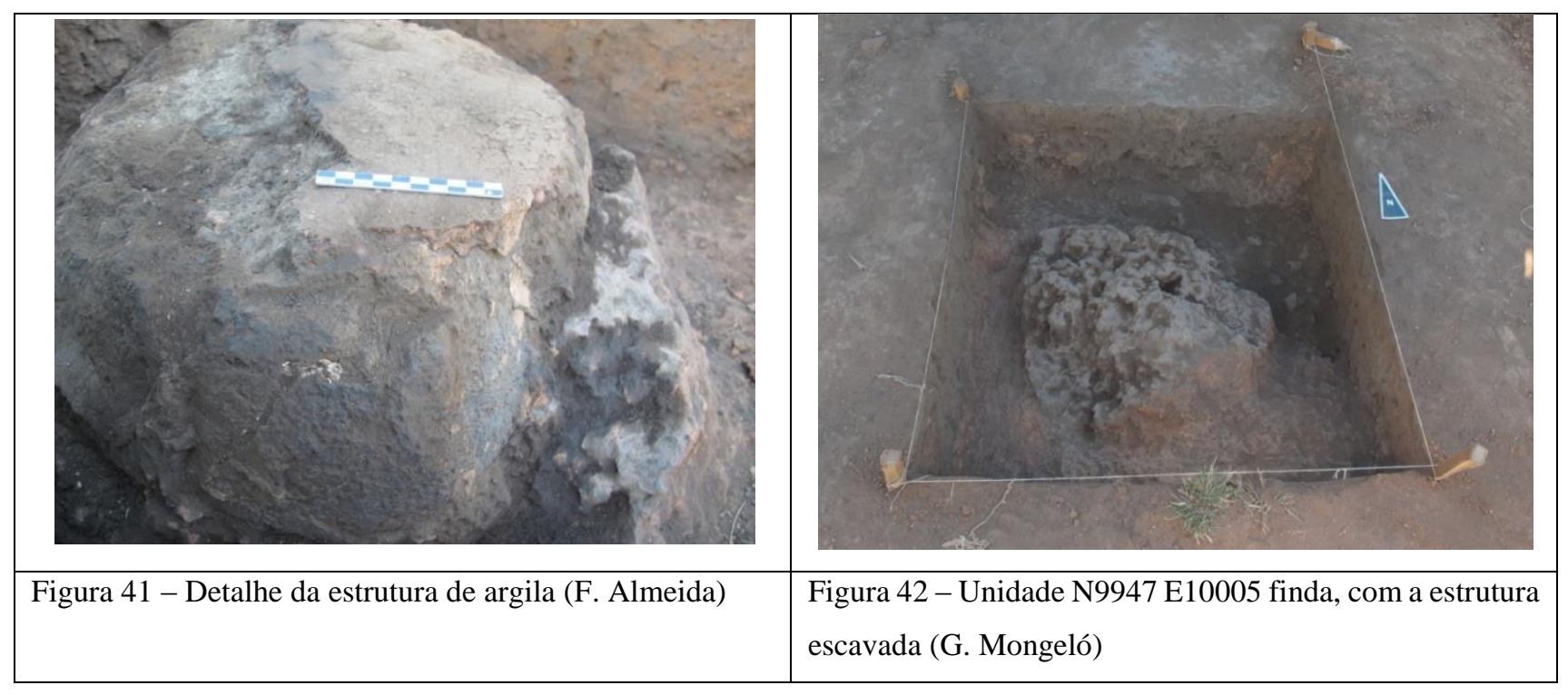

\section{Unidade N9882E10022 (A)}

Tal unidade foi aberta com o mesmo objetivo da N9947 E10005, para a retirada de uma estrutura de cerâmica, que encontrava-se com seu bordo superior exposto na superfície da estrada que corta o sítio; dista 50m daquela, sentido $\mathrm{N}$, em direção a Vila Nova.

Diferente da unidade anteriormente descrita, esta apresentou uma grande quantidade de artefatos líticos lascados em quartzo desde os níveis superficiais, e poucos fragmentos cerâmicos, presentes apenas nos dois primeiros níveis. A estrutura de cerâmica foi retirada em pedestal, inteira, finalizada em $40 \mathrm{~cm}$ de profundidade. 


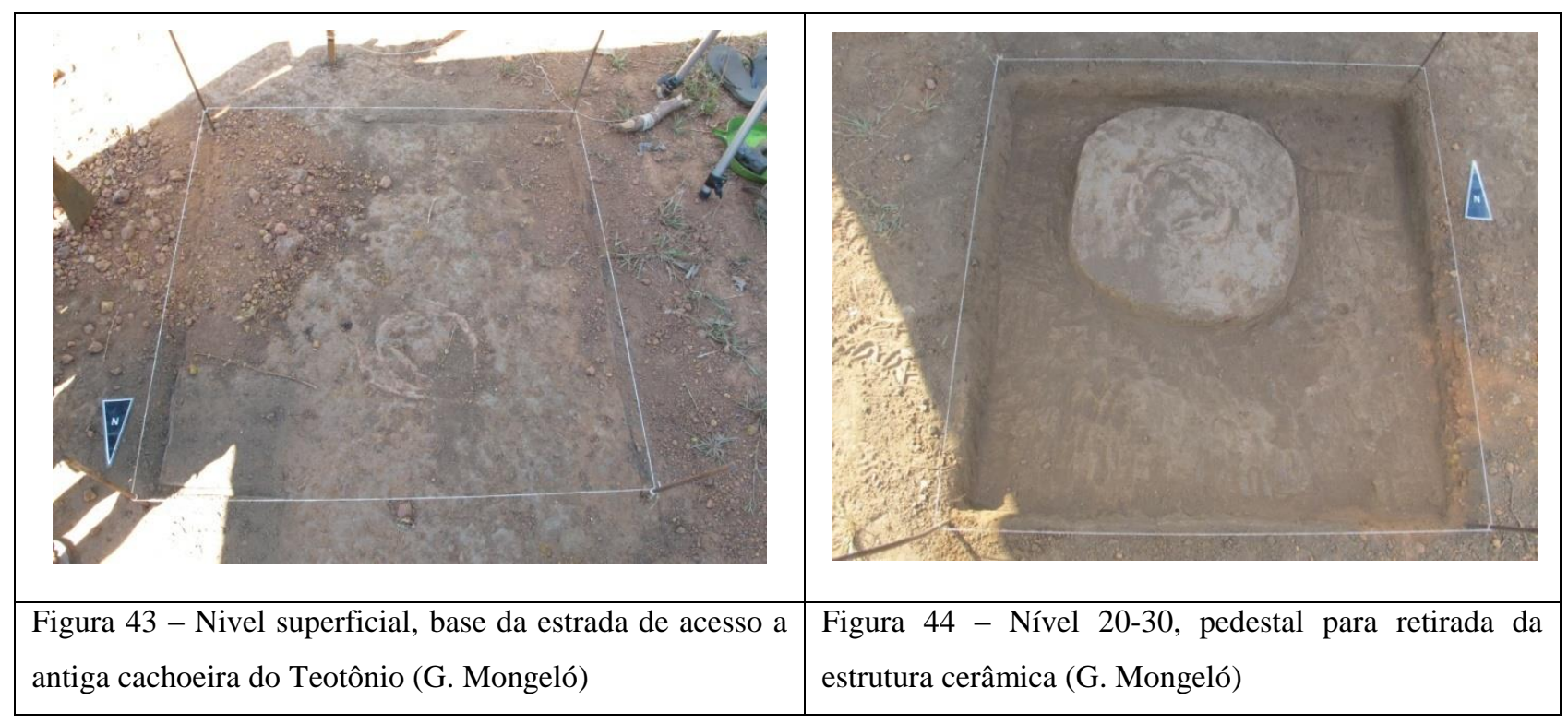

Os níveis subseqüentes revelaram continuidade em relação ao material lítico, que continuou sendo coletado em quantidade considerável, foi possível observar que são em sua maioria lascas unipolares em quartzo hialino e núcleos também da mesma matéria prima. Ocorreu pequena diminuição nos níveis mais profundos, quando da preponderância de rocha friável laterírica. Mais uma vez, não houve nível artificial estéril para material arqueológico.

Com $100 \mathrm{~cm}$ de profundidade, foi evidenciada uma estrutura de fragmentos grandes de carvão (tição) e terra queimada. Tal estrutura foi denominada Feição 6, e retirada em bloco para análise em laboratório, especula-se que esta seja uma estrutura de combustão, pertencente a uma ocupação pré-ceramista. A unidade encerrou-se a $145 \mathrm{~cm}$ de profundidade, devido a impossibilidade de continuar escavando na rocha lateritica

A Feição 6, estrutura de combustão do tipo fogueira foi datada, foi datada em seu miolo, considera-se ser este um contexto base para a ocupação Massangana no sítio. Aas datações do sítio serão tratadas mais adiante.

Pode-se inferir, a partir dos dados até então levantados, sobre essa unidade que:

1- A estrutura de cerâmica retirada em bloco depois de feito o pedestal, constitui-se de uma feição de uma ocupação ceramista (contexto que se perdeu devido a construção da estrada) sobre as camadas pré-ceramistas evidenciadas. 
2- A ocupação pré-ceramista encontra-se também em camada de Terra Preta, comprovando a hipótese, nesse sentido, de modificação antrópica do ambiente anterior a "neolitização"

3- Há, possivelmente, uma ocupação pré-cerâmica, fora de Terra Preta, como podese ver no perfil, a coloração da unidade já é por si só bem menos escura, se comparada com as outras áreas de Terra Preta do sítio. Certamente, necessitam de mais estudos, mas a hipótese levantada aqui é que os conjuntos artefatuais mais profundos possam ser relacionados à essa ocupação que Miller chamou de Complexo Girau.

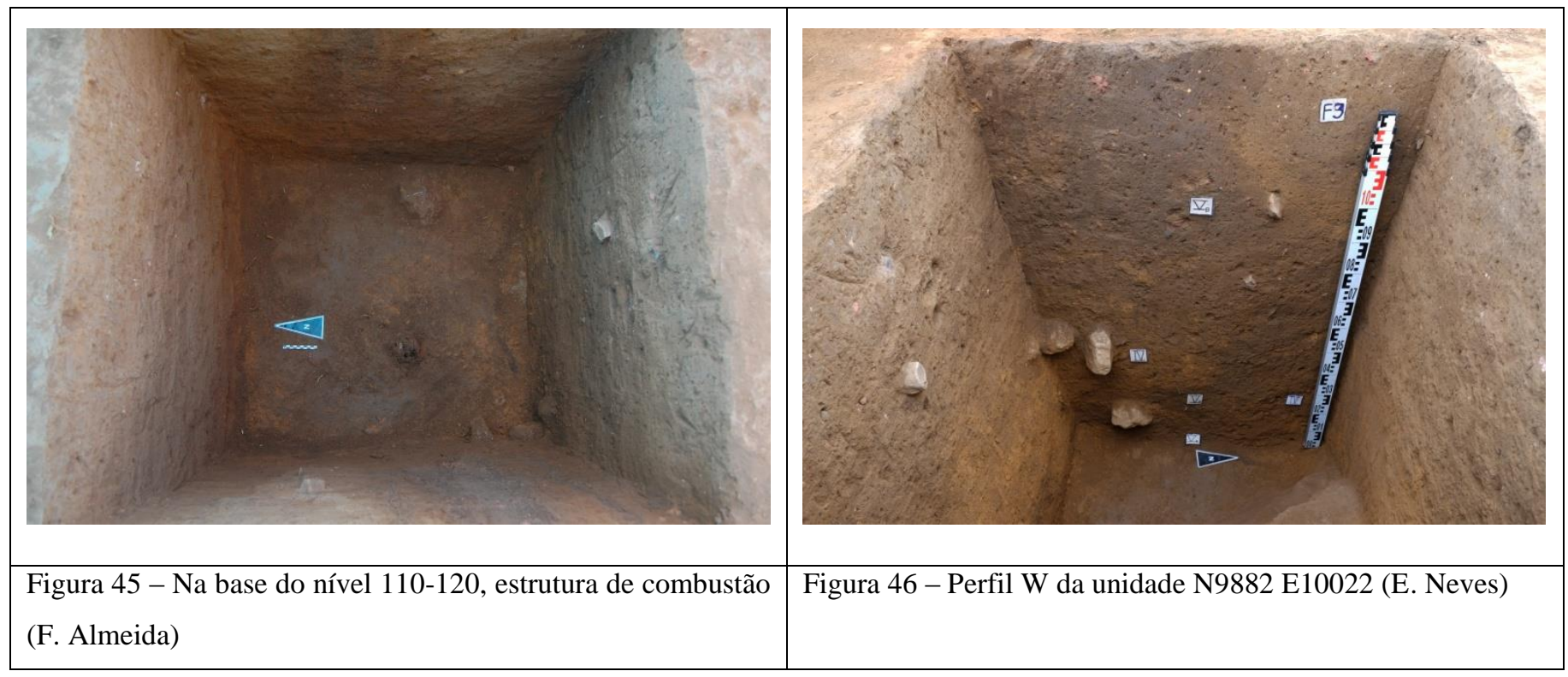

\section{Coletas de Sedimento}

Atividade coordenada pela geoarqueóloga e membro do ArqueoTrop Michelle Tizuka. Para estudos palinológicos, foram feitas coletas de todas as 5 unidades, de $10 \mathrm{em}$ $10 \mathrm{~cm}$, cada uma com aproximadamente $100 \mathrm{~g}$ de sedimento. Das unidades N10041 E9955 e N9882 E10022 foram feitas colunas de sedimento, também de 10 em $10 \mathrm{~cm}$ de profundidade, e de dimensões de $50 \times 20 \mathrm{~cm}$, para flotação a análise paleobotânica dos vestígios. A mesma pesquisadora realizou nas mesmas quadrículas, coletas para 
micromorfologia e datação do solo. Por hora, o material coletado será utilizado em seu projeto de doutorado.

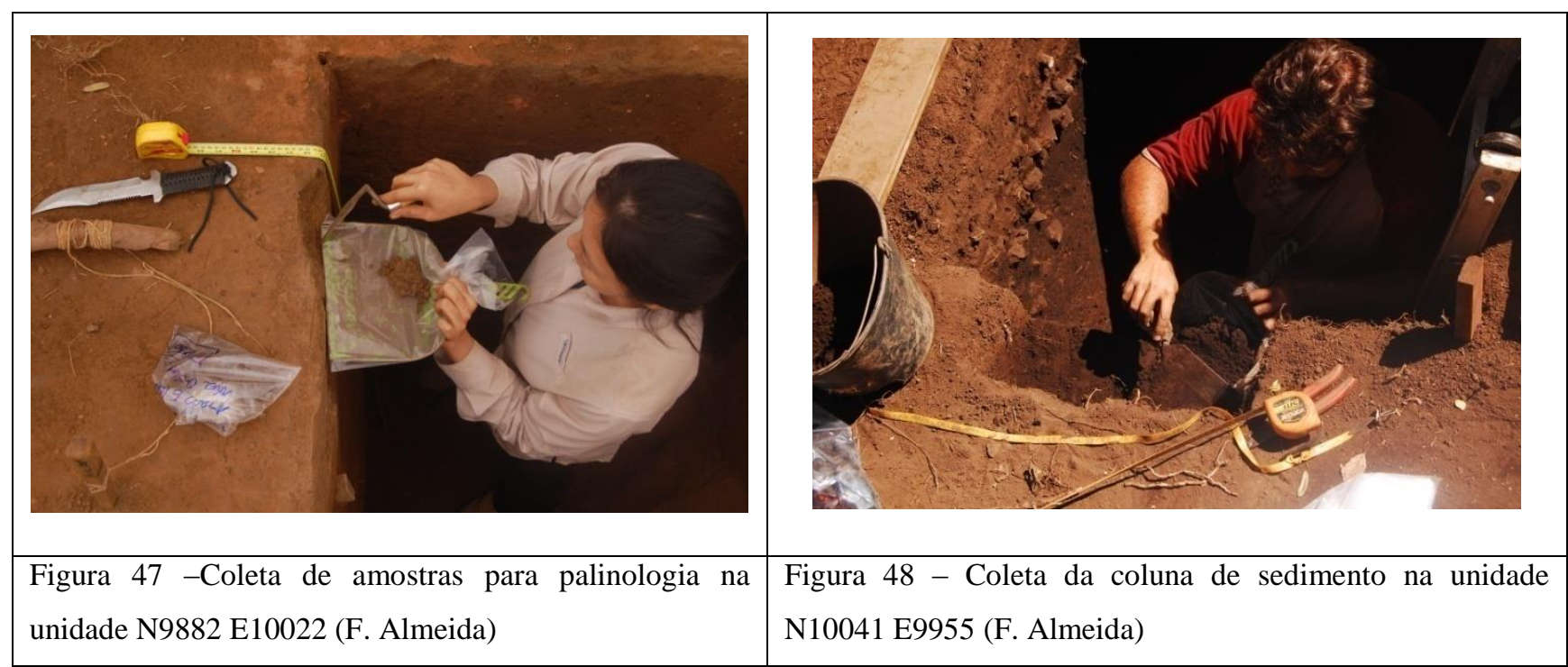

\section{Topografia}

O arqueólogo e membro do ArqueoTrop, Francisco Pugliese Jr., realizou a topografia do sítio a partir das picadas abertas para as linhas de tradagem, munido de um aparelho de Estação Total. O mapa completo, com todas as intervenções, unidades e perfis expostos ainda está sendo construído, mas o mapa com as curvas de nível podem ser vistos na Figura 28.

\section{5.- Análise Preliminar das Camadas Estratigráficas}

Após 3 etapas de escavação, e 36 metros de perfis desenhados, foi possível definir uma composição estratigráfica para todo o sítio, contemplando os diversos contextos escavados, de modo que, o sítio seja interpretado como um todo, e que as camadas das unidades tenham uma baliza como referência. Portanto, por exemplo, a Camada I da unidade N10041 E9955 representa o mesmo contexto arqueológico da Camada I de qualquer outra unidade.

Tal perspectiva parte principalmente da análise da combinação de dois fatores: o tipo de solo e o material arqueológico (e sua presença ou não), a partir destes dois 
elementos, definimos a divisão básica das camadas do sítio. Digo básica pois as mesmas, de acordo com o contexto, possuem flexibilidade de serem divididas, como aconteceu em unidades de escavação que apresentaram mais do que um conjunto cerâmico no mesmo tipo de solo.

Segue breve descrição das mesmas:

- Camada I - Corresponde à rocha laterítica, de origem ferrosa, bastante comum no contexto amazônico, sem presença de material arqueológico

- Camada II- Corresponde também à rocha laterítica, mas com a presença de materiais arqueológicos, principalmente carvões e lascas de quartzo. Foi identificada no grande perfil aberto próximo à estrada e nas unidades N10003 E10003 e N10003 E10004

- Camada III - Corresponde ao contexto de latossolo argiloso de coloração amarelada, sem presença de vestígios antropicos, estéril. Foi identificada na unidade N10001 E10003.

- Camada IV - Designa o mesmo tipo de latossolo argiloso, mas com a presença de materiais arqueológicos, quase sempre de materiais líticos.

- Camada V-Representa o solo do tipo Terra Preta, sedimento antrópico, com a presença unicamente de materiais líticos. Identificada em quase todos os contextos do sítio.

- Camada VI - Camada de Terra Preta Antrópica, com a presença de materiais arqueológicos, líticos e cerâmicos, também é identificada em quase todos os contextos do sítio

- Camada VII - Camada denominada “Antrópico Moderno", corresponde à uma camada claramente modificada pelas ações antrópicas modernas, sejam elas decorrentes da construção da estrada, da retirada de Terra Preta comercialmente, das plantações, etc.

- Camada VIII - Representa a camada húmica, alterada pela ação de elementos orgânicos modernos, como plantas, folhas, raízes, etc. 


\section{6 - Datacões: dados e análise preliminar}

Almeida (2013) havia feito, para o seu mestrado quatro datas para contextos no sítio Teotônio. Sua preocupação era, principalmente, testar as antigas datas que Miller havia publicado para a cerâmica policroma da Fase Jatuarana, que eram até então, as mais antigas para essa cultura cerâmica em toda a Amazônia.

Descartando uma das datas que, provavelmente estava contaminada (Te-805-1) Almeida datou três distintos contextos. O primeiro (Te-709-1), mais recente, corresponde a uma data segura da Tradição Jatuarana, afastando muito da então publicada por Miller (1992), que afirmava que a base de tal complexo estava por volta de 700 a.C. A amostra Te-832-1 corresponde a um contexto ainda não muito claro para nós, pesquisadores, pois compreende um substrato cerâmico que encontra-se abaixo da camada de ocupação da Tradição Jatuarana, certamente mais antigo do que esta. Estamos trabalhando com a hipótese de que seja representativa de uma ocupação relacionada a Fase Jamari, mas tal assertiva merece ser melhor precisa.

\begin{tabular}{|l|l|l|l|l|l|l|l|}
\hline Sítio & Nível & Amostra & No Beta & $\begin{array}{l}\text { Forma de } \\
\text { Datação }\end{array}$ & $\begin{array}{l}\text { Material } \\
\text { Datado }\end{array}$ & $\begin{array}{l}\text { Idade } \\
\text { Convencional }\end{array}$ & $\begin{array}{l}\text { Calibragem 2 } \\
\text { sigma }\end{array}$ \\
\hline Teotônio & $\begin{array}{l}50-60 \\
\mathrm{~cm}\end{array}$ & Te-709-1 & 323281 & A M S & Carvão & $1250+/-30$ BP & AD 680 a 830 \\
\hline Teotônio & $\begin{array}{l}110- \\
120 \mathrm{~cm}\end{array}$ & Te-716-1 & 323282 & A M S & Carvão & $3170+/-30$ BP & $\begin{array}{l}1500 \text { a } 1410 \\
\text { BP }\end{array}$ \\
\hline Teotônio & $37 \mathrm{~cm}$ & Te-805-1 & 323283 & A M S & Carvão & Presente & Presente \\
\hline Teotônio & $65 \mathrm{~cm}$ & Te-832-1 & 323284 & A M S & Carvão & $1550+/-30 B P$ & 430 a 580 AD \\
\hline Teotônio & $\begin{array}{l}100- \\
110 \mathrm{~cm}\end{array}$ & Te- 1966 & 408414 & A M S & Carvão & $5720+/$-BP & $\begin{array}{l}6495 \text { a } 6400 \\
\text { BP }\end{array}$ \\
\hline
\end{tabular}

Figura 49 : Tabela com as datações do sítio Cachoeira do Teotônio. Adaptado de Almeida

(2013)

As datas em laranja (Te-709-1 e Te-1966) correspondem, respectivamente, ao topo e a base da ocupação Massangana no sítio Teotônio. A primeira amostra foi retirada 
da unidade N10003 E10001, escavada em 2011, localiza-se no topo de uma feição onde foram encontrados apenas fragmentos líticos em solo antropizado. A segunda, (Te-1996) foi datada de uma estrutura de combustão do tipo fogueira, na unidade N10022 E9882, esta, escavada em Agosto de 2013. Tal fogueira foi evidenciada no limite do solo de Terra Preta com o latossolo amarelo, a $110 \mathrm{~cm}$ de profundidade.

Esses dados colocam o contexto de Terra Preta antropizada sem presença de material cerâmico abarcando boa parte do Holoceno Médio de 6500 AP a 3200 AP. Vale dizer que há a probabilidade de encontrarmos datas mais antigas no sito, na medida em que se continuarem as pesquisas, uma vez que foi evidenciado um contextos de líticos lascados abaixo da dita fogueira, fora da Terra Preta, na mesma unidade. 


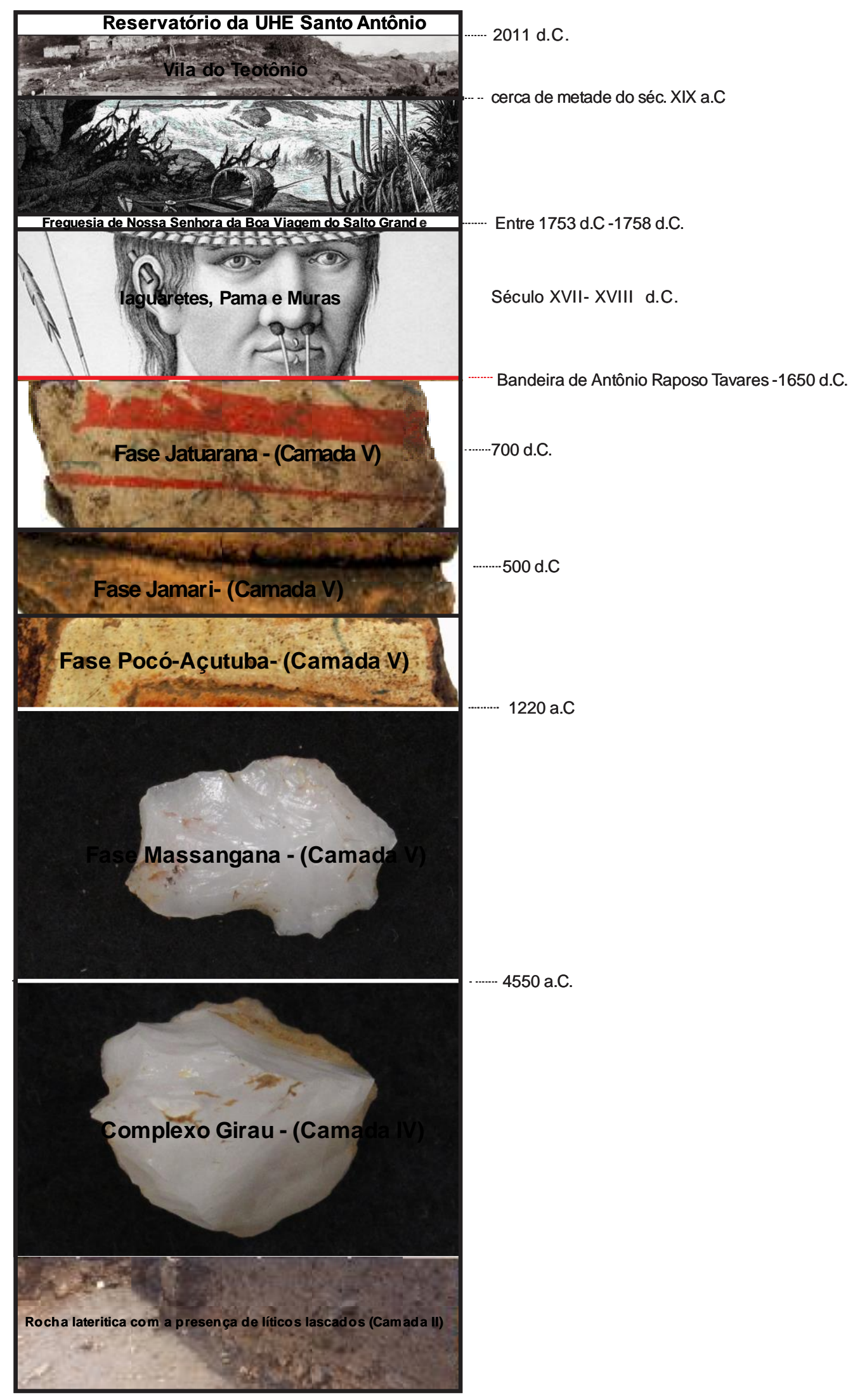

Figura 40b - Perfil esquemático das ocupações culturais do sítio Teotônio 


\section{Capitulo 4 Análise dos Vestígios Arqueológicos}

\section{1 - Metodologia de Análise}

O objetivo desse capítulo é descrever a análise dos materiais arqueológicos provenientes das escavações do sítio Teotônio nas duas campanhas realizadas em 2013 e apresentadas no capítulo anterior. Participar como aluno ou pesquisador do ArqueoTrop implica na comunhão inevitável de diversas práticas de análise de materiais arqueológicos, de forma que quase exclusiva, sobre fragmentos cerâmicos. E os anos de pesquisa do Projeto Amazônia Central contribuíram de forma extremamente positiva na elaboração de uma metodologia amplamente difundida pelos alunos do prof; Eduardo Neves, de forma que quase todas as dissertações e teses dos seus orientandos, quando da descrição da metodologia de análise em laboratório, citam-se uns aos outros.

Nessa dissertação, no entanto, um dos objetivos principais, como já colocado na Introdução, é a caracterização das indústrias líticas do alto Rio Madeira, e em segundo lugar, o entendimento do complexo ceramista antigo presente no Teotônio, o que implicou em um esforço maior devido à escassez de estudos sobre líticos, no Laboratório 1 do MAE, e na Amazônia como um todo.

Assim, foi um desafio desde o princípio compreender quais seriam os questionamentos certos para esse tipo de material, a montagem da ficha de análise e a análise propriamente dita. Foi de grande contribuição as dicas dos companheiros Francisco Pugliese, Fabiana Belém, Vinicius Honorato e prof. Paulo De Blasis, que dispuseram tempo para auxiliar de diversas maneiras.

A etapa de campo e 2011 no sítio Teotônio revelou (para nós, uma vez que Miller já havia se dado conta), a existência de camadas pré-cerâmicas, marcada pela continuidade da Terra Preta, e pelo sumiço, na estratigrafia dos pacotes arqueológico, de fragmentos cerâmicos. Dada esta suposição, de que de fato há uma ocupação nãoceramista, a pergunta, basicamente se tornou, o que caracteriza essa indústria lítica?

A primeira característica visível, e que teve uma influência direta no tipo de metodologia aplicada, é a quantidade enorme e o tamanho diminuto das lascas e dos núcleos. Na unidade N10001 E10003, escavada em 2011, só para se ter uma ideia, foram coletados 4532 peças líticas, sendo 3251 menores do que $1 \mathrm{~cm}$ (Almeida, 2013). 
Não haveria, portanto, nem tempo nem disposição física para uma análise qualitativa de grande preciosidade, com atributos que contribuíssem para uma descrição detalhada. Bueno \& Pereira (2007) dizem que e o uso de uma ficha detalha de análise no contexto se dá pelo fato de "não haver um conhecimento prévio sobre o material lítico deste sítio ou de outros sítios associados a ocupações ceramistas nessa região, criando assim a necessidade de se efetuar uma boa caracterização tecnológica dessa indústria”. No entanto, é importante frisar que no mesmo estudo, os dois possuem cerca de $10 \%$ de material lítico, se comparados quantitativamente com a coleção do sítio Teotônio, o que favorece uma análise minuciosa.

De fato, é necessária uma boa caracterização da indústria que é praticamente desconhecida, a identificação da sequência operacional que envolve a obtenção e transporte de matéria-prima, manufatura dos instrumentos, uso, descarte e reciclagem dos mesmos (Schiffer, 1972) e a análise sistêmica da cadeia operatória como ferramenta para o entendimento de questões do tipo: como foram feitos os instrumentos, por que foram feitos? (Andrefsky 2008, 2009).

No entanto, é preciso ter em mente os objetivos gerais desta dissertação, enfatizados na Introdução. Ou seja, uma análise da cadeia operatória, meticulosa, com os mais de 8 mil fragmentos líticos coletado no sítio Teotônio, será essencial para o entendimento dos processos de transformação de sociedade ditas caçadoras-coletoras em populações sedentárias ceramistas?

Daí a necessidade de fazer a equação dos fatores tempo, disposição e resultados obtidos para se pensar a estratégia correta de análise de material. A falta de uma tradição de estudos sobre a indústria lítica amazônica, e de um modo geral, a dificuldade de se analisar instrumentos em quartzos (Isnardis, 2008), nos levaram a montar uma ficha de análise de desse conta do volume de material, contemplasse o objetivo de caracterizar de forma inicial o conjunto artefatual e contribuísse para o entendimento do processo como um todo.

Tal qual Belém (2012) entende que nesta pesquisa "a descrição das peças e da indústria em si não é o objetivo exclusivo, mas principalmente explorar o quanto estes materiais podem ajudar na investigação do estilo de vida (...), seus padrões de subsistência e adaptabilidade, assim como na construção de hipóteses relacionadas à 
ocupação dos diferentes espaços". Dadas as devidas proporções, uma vez que Fabiana Belém trabalhou com contextos costeiros, sua metodologia, elencando atributos relevantes para a compreensão do modo de subsistência geral das sociedades é uma referência para a proposta aqui colocada.

Sendo assim, decidiu-se trabalhar com o material lítico através de lotes separados, e não as unidades isoladas, muito devido à grande quantidade. Os lotes correspondem aos níveis artificiais das escavações, que possuem PN próprio cada um. Mais de $98 \%$ da indústria compõe-se de lascas ou núcleos, sendo que nos contextos pré-cerâmicos é assim em sua totalidade. Dessa forma, a ficha (Anexo 8) de análise aplicada aos lotes foi pensada, de forma preponderante, à esse suporte; os demais vestígios líticos, pela pequena quantidade, foram descritos separadamente, e quantificados pela denominação de "artefatos".

A ficha, que segue em anexo, portanto, tem como objetivo uma caracterização quantitativa da indústria de lascas e núcleos, levando em conta os seguintes atributos:

- Matéria Prima: Quartzo / Quartzo hialino / quartzo leitoso

- Suporte: (lasca/núcleo)

- Técnica de lascamento: (Unipolar / Bipolar)

- Tamanho( menor de $1 \mathrm{~cm} /$ menor de $2 \mathrm{~cm} /$ maior de $2 \mathrm{~cm} /$ maior de $3 \mathrm{~cm}$ )

Vale fazer as seguintes ressalvas sobre a aplicação da ficha, e até agora foram analisadas duas unidades de $1 \mathrm{~m}^{2}$, lascas com marcas de retoque foram enquadradas na categoria artefato, e descritas individualmente, assim como núcleos esgotados de formato circular que aparentam terem tido função de raspadores (Miller 1992). Artefatos polidos e percutores também foram descritos individualmente e contabilizados em "artefatos".

Dessa forma, acredita-se que os dados obtidos serão suficientes para lançar luzes iniciais sobre essa indústria, fazer comparações entre as indústrias líticas das camadas ceramistas e pré-ceramistas, entender a dispersão deste material no sítio, e fazer inferências sobre seus usos.

Decidiu-se também analisar o material cerâmico por dois motivos principais: primeiro porque o sítio Teotônio precisa ser entendido como uma unidade, e a compreensão da formação do registro é essencial para o estudo do processo "neolítico". 
Além do mais, as duas campanhas de 2013 geraram uma quantidade considerável de passivo de material arqueológico, que necessitam de estudo. Inclusive, as atividades de estágio com alunos da graduação da USP que por hora ocorrem no ArqueTrop estão sendo feitas justamente sob o material cerâmico do Teotônio.

A metodologia de análise do material cerâmico segue a mesma linha de todos os trabalhos de alunos do ArqueoTrop, como dito, levando em conta os anos de desenvolvimento da técnica pelo PAC e os aperfeiçoamentos feitos pelo Fernando Almeida, quando do seu doutoramento (Almeida, 2013, Neves, 2013).

No sítio Teotônio, quando da análise do material cerâmico da campanha de 2011, ficou clara a presença de mais de um substrato cerâmico. Almeida (2013) datou uma "cerâmica sem decorações pintadas, com decorações plásticas rústicas e predominantemente temperada com antiplastico mineral" em 400 d.C, data anterior às obtidas para a cerâmica policroma Jatuarana, embora não tenha ficado claro que esta tenha sido representativa de uma ocupação sólida mais antiga. A grande característica do conjunto cerâmico apresentado por Almeida é a variabilidade de decorações, formas e tipos de pasta presente, o que dificultou o exercício de formação de conjuntos culturais, mas que de forma positiva nos fez pensar no sítio Teotônio como um lugar de amálgama de diversas características, algo que ele denominou de "transmissão horizontal de elementos cerâmicos".

Levantamos a questão da importância significativa da paisagem da cachoeira do Teotônio para as sociedades coloniais e neo-brasileiras,e supomos que não tenha sido diferente em épocas pré-cabralinas. Trabalhando com a idéia de "lugar persistente" (Moore \& Tompson, 2012), Almeida crê na cachoeira como um núcleo, um entroncamento, de rede de caminhos aquáticos e terrestres amazônicos, um lugar para a realização de trocas comerciais, rituais festivos de iniciação, troca de mulheres, etc.; e nessa lógica de contato constante, idas-e-vindas, estaria a explicação da multimaterialidade dos motivos decorativos cerâmicos.

No entanto, vale ressaltar que quando Almeida redigiu sua tese, não havíamos ainda realizado a terceira etapa de campo, em julho de 2013, onde, entre tantas outras coisas, foi evidenciada e escavada no sítio um contexto com $3 \mathrm{~m}$ de profundidade de Terra Preta e cerâmica, a unidade N100041 E9955. Entende-se que a análise desse material 
cerâmico é essencial para o entendimento das formas de ocupação do sítio, primeiro para testar a hipótese de Almeida sobre a variedade dos elementos estilísticos, e segundo, para entender o hiato cronológico que há entre a data mais recente da ocupação pré-cerâmica $(1120+30$ a.C) e a data mais antiga para a ocupação ceramista (400+30 d.C).

A análise do material cerâmico seguirá sendo a mesma utilizada pelo PALMA desde 2008 (Almeida,2013; Azeredo, 2011) que leva em conta os anos de acúmulo sobre o tema dos alunos do Projeto Amazônia Central, e os subsequentes refinamentos (Neves, 2013, Tamanaha, 2012, Lima, 2013, Lima 2008, Machado, 2005). São feitas, basicamente, dois tipos diferentes de análises: uma quantitativa, correspondente à etapa de triagem do material, e uma qualitativa, que é exemplificada pela aplicação da ficha e pela análise formal dos vasos.

Higienizado o material cerâmico, o mesmo é separado em duas grandes categorias: diagnósticos e não diagnósticos. Consideram-se fragmentos diagnósticos aqueles que possam nos oferecer algum tipo de informação que exceda a quantidade e o peso, ou seja, paredes decoradas, bases, bordas e paredes com fuligem. Na etapa da triagem, essas categorias são separadas, numeradas e pesadas separadamente, o material diagnóstico recebe identificação através de um código que representa o sítio, o número de proveniência e sua numeração individual (ex. TE- 2101-1). Até esse momento da pesquisa, esse processo foi feito em todo o material cerâmico do sítio Teotônio.

Após a triagem, e a numeração dos fragmentos diagnósticos, é aplicada a "ficha de análise" (Anexo 7), individualmente a cada um dos fragmentos, buscando uma análise, aí sim, qualitativa do material, através de 26 atributos, onde se intentará buscar padrões nas técnicas de confecção dos vasos. Essa atividade ainda esta sendo feita em laboratório, e é parte central do projeto de Iniciação Cientifica de Thiago Kater (Kater, 2014), aqui apresentaremos apenas algumas conclusões sobre as camadas cerâmicas identificadas até então; 


\subsection{Análise dos vestígios líticos arqueológicos da campanha Fev/2013}

Como explicado no capítulo anterior, da unidade ampla de $2 \times 2 \mathrm{~m}$ aberta na campanha de Janeiro de 2013, só foi possível concluir a escavação de duas quadrículas, a N10003 E10004 e N10003 E10003, devido a grandes quantidades de chuvas e consequente alagamento da unidade. O principal questionamento em relação à essa unidade era confirmar a existência de uma camada pré-cerâmica, comparar a estratigrafia com a unidade aberta em 2011 e obter quantidade significativa de coleção arqueológica para análise. O material cerâmico foi lavado, triado e numerado, assim como o material lítico, que recebeu o tratamento descrito nesse capítulo.

As escavações evidenciaram, nessas unidades, 1976 fragmentos cerâmicos, retiradas as paredes sem decoração e as bolotas de argila, temos uma amostragem não muito grande de 320 fragmentos diagnósticos.

\begin{tabular}{|l|r|r|}
\hline TOTAL & Quant. & Peso (g) \\
\hline Borda decorada & 15 & 274 \\
\hline Borda n decorada & 138 & 440 \\
\hline Parede decorada & 67 & 228 \\
\hline Parede ñ decorada & 1629 & 4886 \\
\hline Base decorada & 1 & 10 \\
\hline base ñ decorada & 14 & 140 \\
\hline Parede fuligem & 85 & 450 \\
\hline
\end{tabular}

Figura 50 - Tabela do resultado da triagem das unidades N10003 E10004/N10003 E10003

Em relação ao material lítico, foram analisados 969 peças diagnósticas, sendo apenas 3 instrumentos polidos, e o restante resultantes de atividades de lascamento, sendo $27 \%$ lascas unipolares, $33 \%$ lascas bipolares, 35\% núcleos e $4 \%$ artefatos, do total de diagnósticos. 


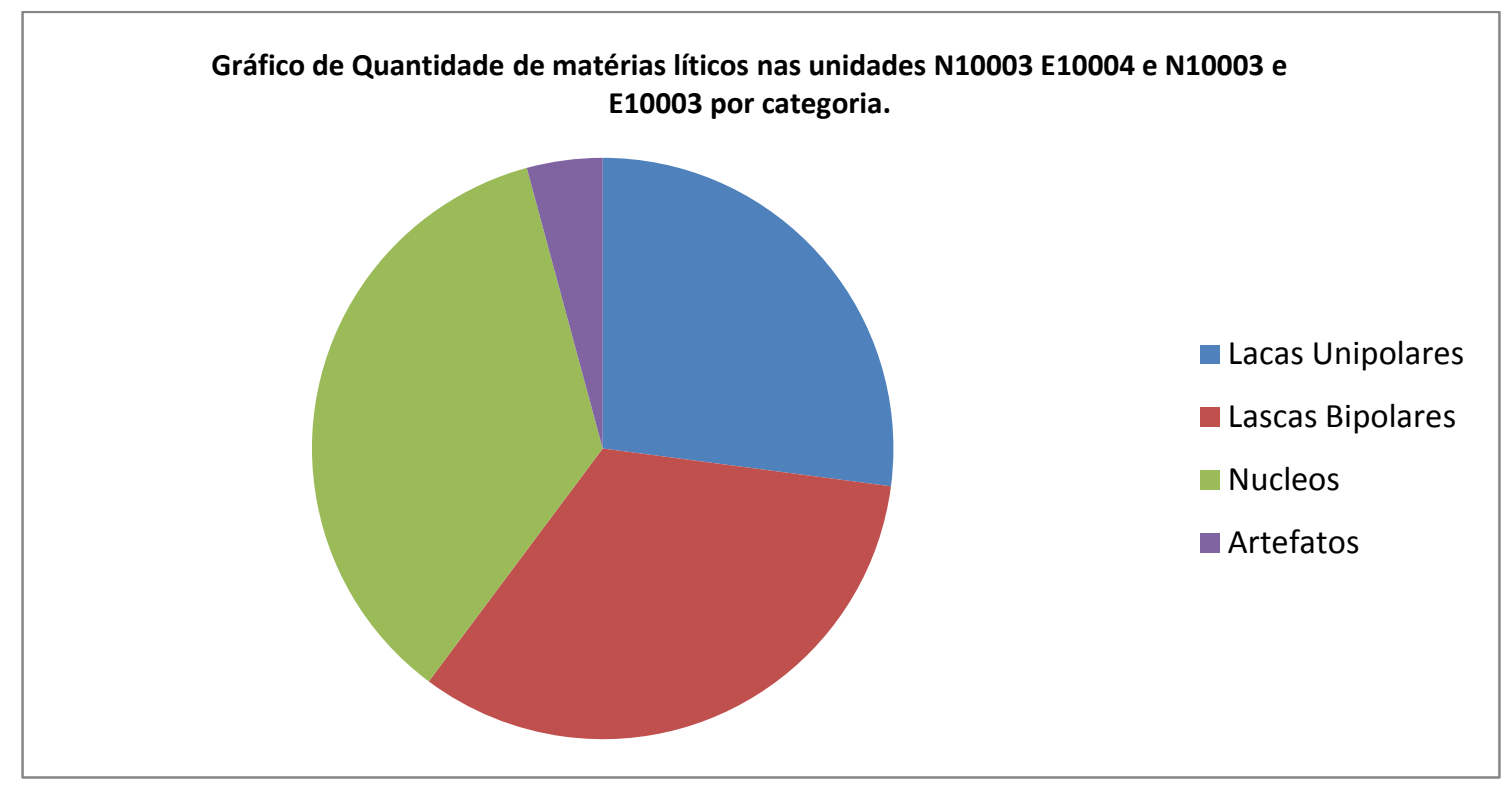

Figura 51 : Gráfico de Quantidade de matérias líticos nas unidades N10003 E10004 e N10003 e E10003 por categoria

A análise do gráfico de quantidade de material cerâmico por nível mostra, tal qual os resultados da escavação de 2011 (Almeida, 2013), uma diminuição drástica da presença de fragmentos cerâmicos a partir do nível $20-30 \mathrm{~cm}$, que em certa medida é acompanhada pela incidência total de materiais líticos, com um pico comum ao redor dos $30 \mathrm{~cm}$ de profundidade. No entanto, o gráfico deixa claro que há uma camada entre 30 $\mathrm{cm}$ e $90 \mathrm{~cm}$ de profundidade onde a presença de fragmentos cerâmicos é quase nula, enquanto o número de lascas, núcleos e refugos permanece ao redor dos 100 fragmentos.

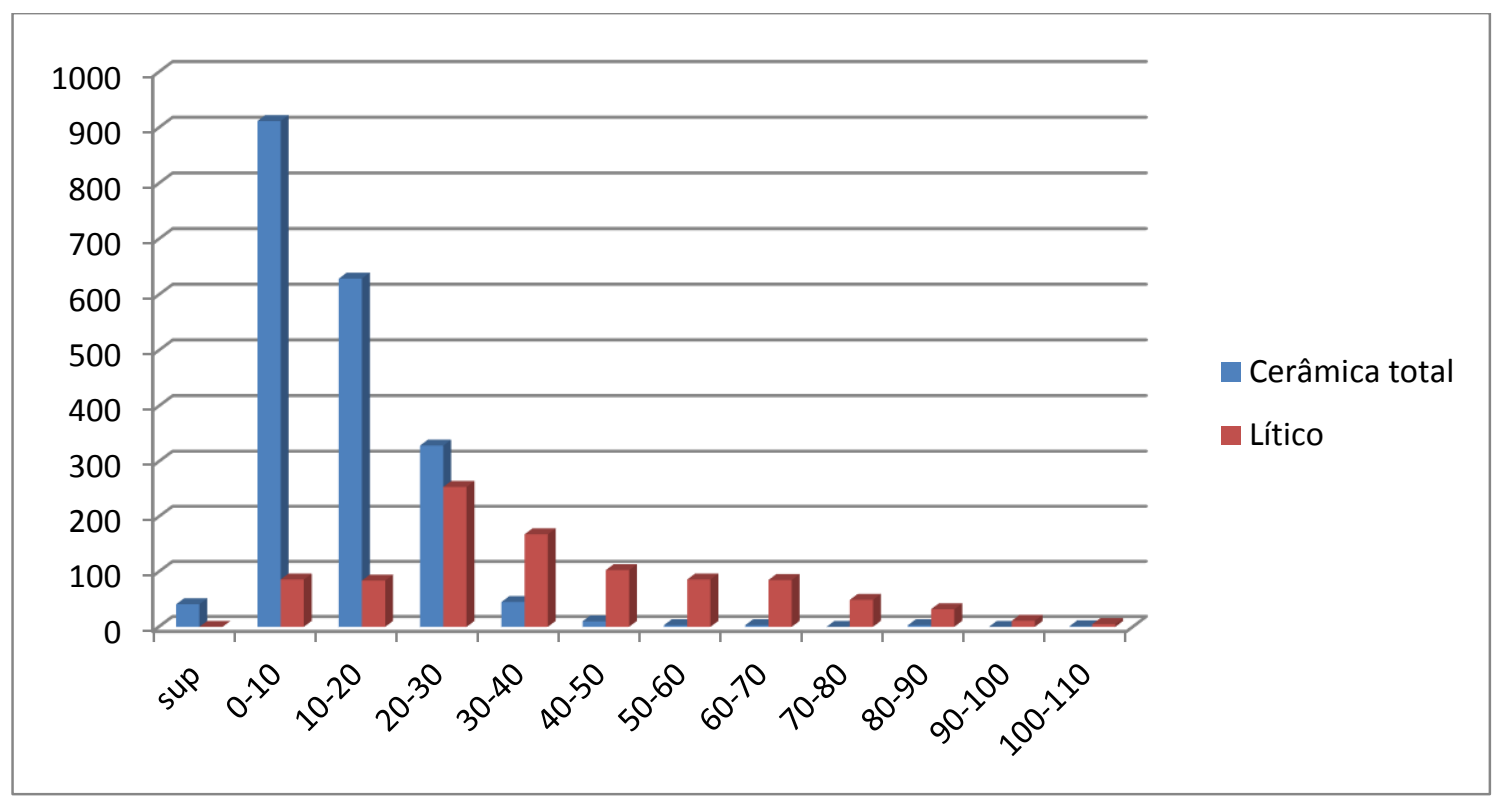

Figura 52 - Incidência de material lítico e cerâmico, por nível, nas unidade N10003 E10004 e N10003 E10003 
Dessa forma, acredita-se que seja possível, afirmar que existe de fato uma ocupação lítica, com presença substancial de material, em solo antrópico no sítio Teotônio. A imagem 53 mostra o substrato correspondente a esse contexto; embora seja visível a mudança na coloração do solo, , não são necessárias grandes análises para crer que a camada V (entre o tracejado vermelho) configura-se como um solo antropizado. Tal inferência vai ao encontro das hipóteses levantadas pela análise do perfil de $15 \mathrm{~m}$ aberto paralelo à estrada, corroborando para a interpretação das camadas estratigráficas do sítio, apresentadas no capítulo anterior.

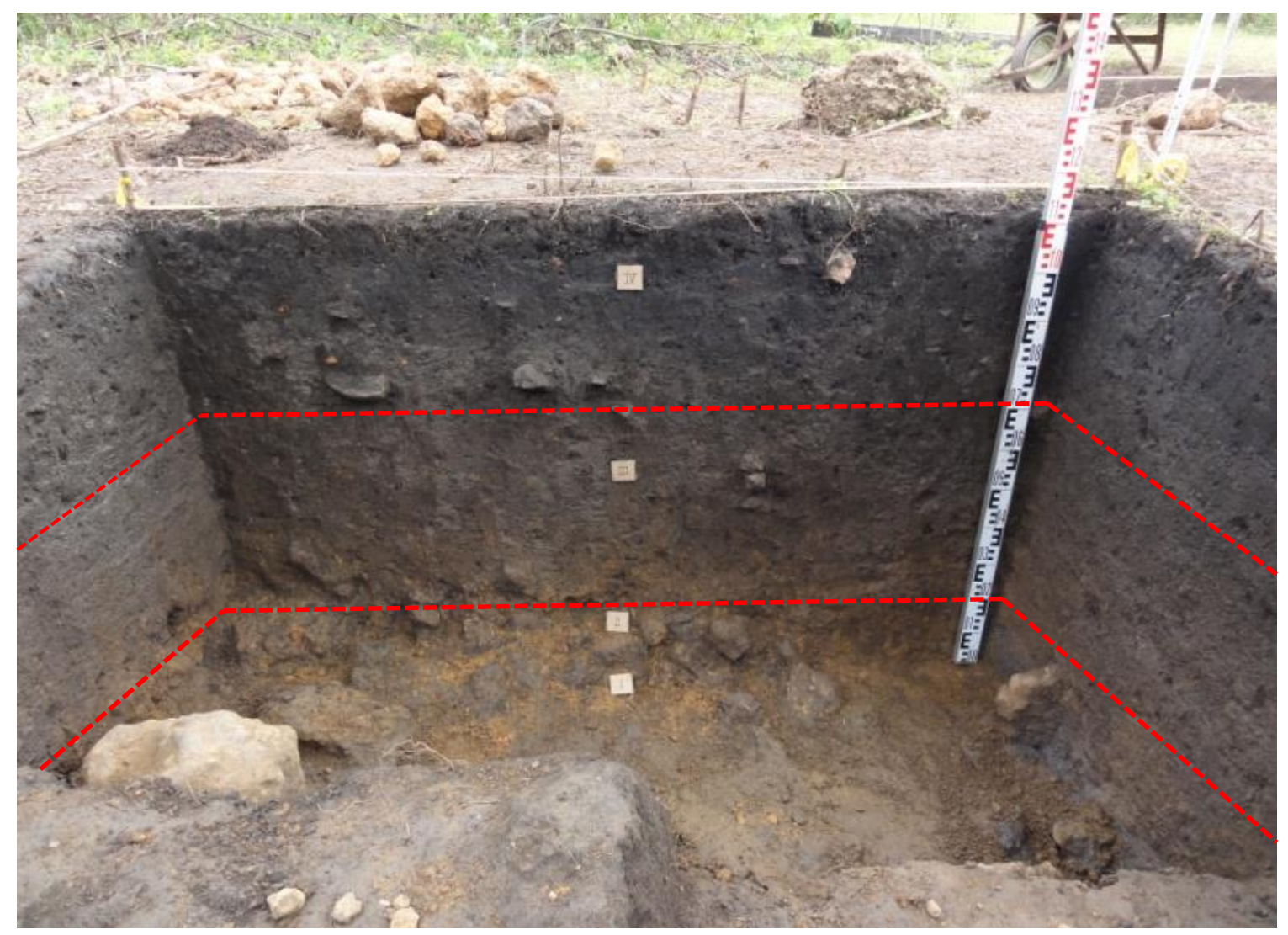

Figura 53 - Perfil Sul das unidade N10003 E10004 e N10003 E10003; entre o tracejado vermelho, a camada pré-cerâmica. 


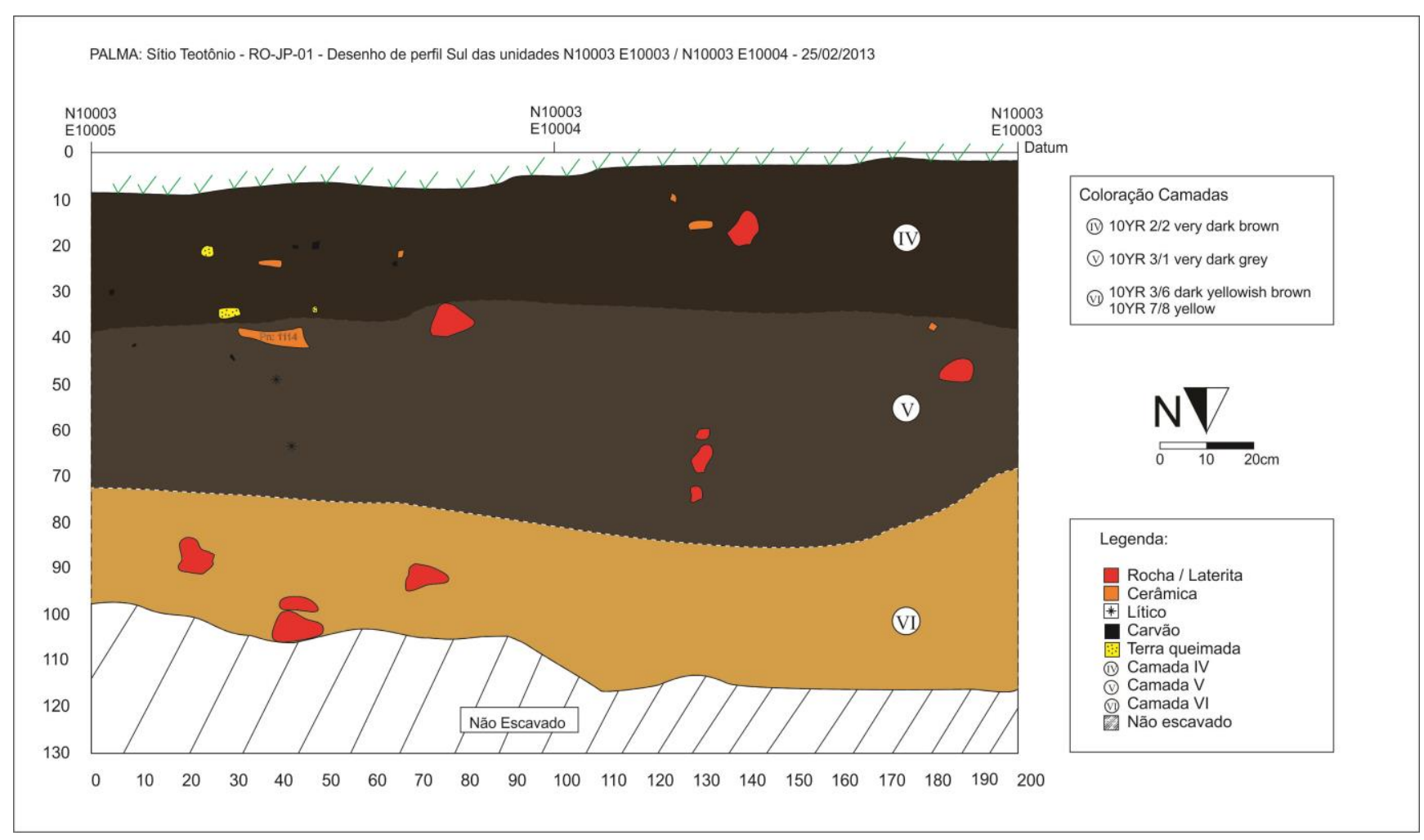

Figura 54 - Perfil Sul das unidades N10003E10003 / N10003 E10004

Em relação à análise do material lítico das duas unidades, pode-se mostrar que aparentemente, não há preferência para o uso de matéria prima, que se resume unicamente ao quartzo e suas variações, reflexo da obtenção de matéria prima local. É provavelmente oriundo de veios de igarapés e áreas de cabeceiras, hipótese que levantamos através da observação dos fragmentos de lascas corticais, que não apresentam características do tipo de seixos, esta outra possível fonte de matéria-prima. 


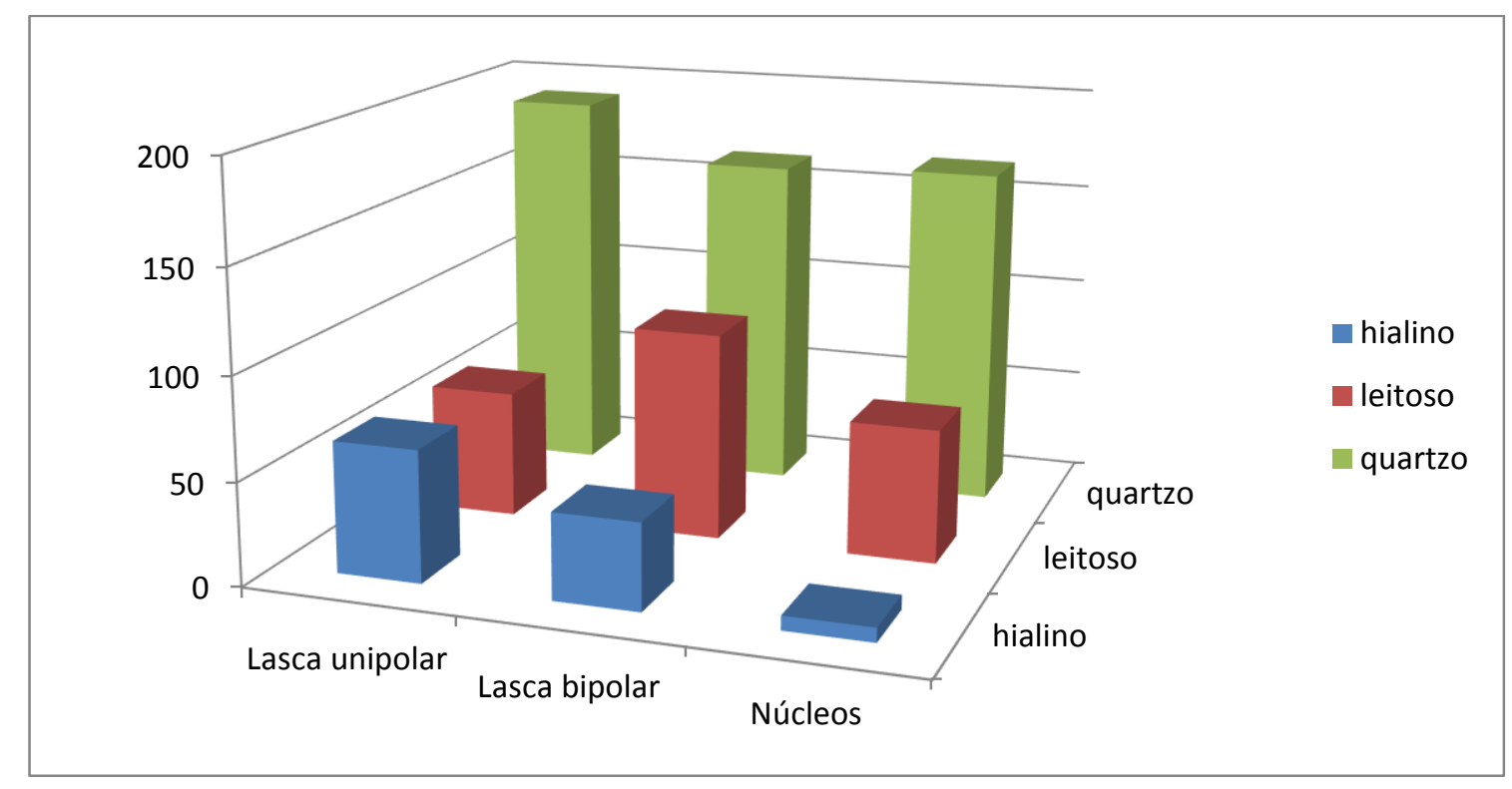

Figura 55 - Quantidade de líticos divididos por categorias (núcleos e tipos de lascas) por matéria-prima.

Partimos desse pressuposto, portanto, de que a matéria prima é oriunda não dos seixos do Rio Madeira e afluentes, mas sim de veios de quartzo, das regiões de cabeceiras dos igarapés e pequenos afluentes. No entanto, a inundação destes igarapés e o aumento do nível de água do Rio Madeira pela construção da usina hidrelétrica de Santo Antônio impossibilitaram qualquer busca por fontes de matéria-prima próxima, uma vez que estes possíveis locais estão, hoje, sobre a água. De qualquer maneira, sabe-se também que afloramentos de quartzo em áreas de terra firme existem nas áreas altas da várzea do Madeira, encontramos um destes sítios na etapa de prospecção arqueológica no município de Nova Mamoré, em 2013.

O sítio lítico oficina Laje trata-se de um achado fortuito de bastante significação para o entendimento da obtenção de matérias-primas na região. Encontra-se consideravelmente longe do Rio Madeira e do Teotônio (225 km em linha reta), mas é, até agora, a única fonte de quartzo identificada na bacia do Alto Madeira. Está localizado na margem direita do Rio Mamoré, próximo à sede do município de Nova Mamoré; em linha reta fica a $3 \mathrm{~km}$ a Leste do ponto mais próximo do rio, a margem direita da cachoeira Laje. É um sítio de dimensões pequenas, de aproximadamente $30 \mathrm{~m}$ de diâmetro, tendo em seu centro um afloramento grande de rochas do tipo quartzo, quebradas por ação antrópica. Por entre as rochas e ao seu redor, são inúmeras as lascas e fragmentos de lascas, objetos formais e refugos de lascamento (UTM 20L 241724 8843933). 
Por mais que tenha sido muito improvável que esta tenha sido uma fonte de matéria-prima utilizada pelos antigos habitantes da cachoeira do Teotônio, não se descarta a possibilidade de que haja outros sítios como este nas proximidades do sítio estudado.

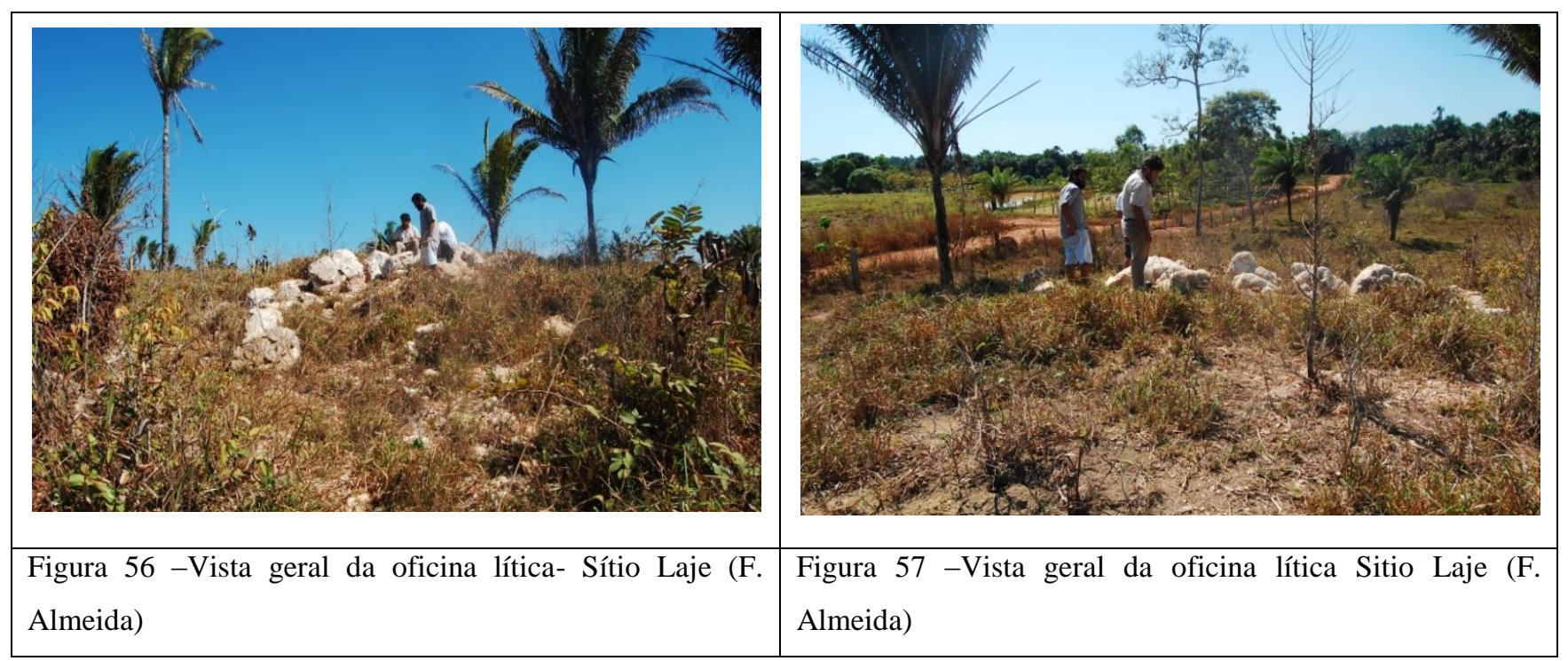

Miller (1992) afirma que, tanto em sítios pré-cerâmicos do rio Madeira e do rio Jamari o sílex aparece também como fonte de matéria prima de lascas unipolares e bipolares, e os estudos até agora publicados sobre a indústria lítica de sítios ceramistas resgatados pela Scientia Consultoria quando da construção da UHE Santo Antonio (Noletto, 2013) também indicam a presença, ainda que pequena, de lascas e núcleos em sílex, em sítios distantes não mais do que $30 \mathrm{~km}$ do Teotônio.

No entanto, na amostra analisada até agora, não foi evidenciado nenhum artefato nessa matriz, o que nos coloca uma pergunta interessante, se pensarmos que esses grupos, na definição clássica de pré-ceramistas, teriam uma mobilidade alta e um padrão de ocupação do espaço amplo. Sabemos que existe a oferta de matéria prima (sílex) na região, portanto, levantamos duas hipóteses, que não são excludentes. A ausência do sílex deve se dar por questões culturais de escolha, visto que as populações que habitavam a margem da cachoeira do Teotônio tinham preferência única pelo quartzo, ou as mesmas não tinham mobilidade espacial grande, o que corrobora com a presença de Terra Preta, um indicador de permanecia e estabilidade.

Em relação à tecnologia de fabricação de lascas, não há qualquer relação que se possa fazer entre fonte de matéria prima e preferência por modo de percussão no Sítio 
Teotônio. Existe um senso comum, que devido ao tamanho diminuto das matérias primas em quartzo, na Amazônia em geral, as indústrias líticas são basicamente formadas por produtos resultantes de lascamentos bipolares, com a exceção de contextos onde a oferta de matérias-primas seja abundante e diversa, como são os casos na Serra dos Carajás. Na verdade, existem pouquíssimos registros de contextos de sítios a céu aberto com indústrias líticas pré-ceramistas na Amazônia, Oliveira (2007) dá destaque para dois sítios escavados pela Scientia Consultoria, às margens da barragem de Tucuruí, no nordeste do Pará. Os sítios Breu Branco I e Breu Branco II, distantes 2 km um do outro, apresentam características diferentes da região do Alto Rio Madeira, mas até o momento, são poucos pontos de comparação (Souza, 2013), na floresta amazônica, com o contexto semelhante ao aqui estudado.

Oliveira (2005) mostra que o "material lítico da ocupação caçadora-coletora deste(s) sitio(s) está diretamente relacionado à disponibilidade de matéria-prima local", que basicamente são seixos de quartzo. No sítio Teotônio, mesmo assim, a técnica mais utilizada é o lascamento unipolar, embora haja, em quantidade considerável, lascamentos bipolares. Para ele, a criação de planos de lascamento sobre os seixos "era feita mais pelo uso da força do que pela utilização da técnica bipolar ou unipolar", utilizando-se qualquer plano que quebra do seixo. De certo modo, ele enxerga a técnica da bipolaridade como uma implicação necessária imposta pela natureza da matéria-prima.

No sítio Teotônio, a análise da indústria lítica feita até agora também não indicou preferência para qualquer tipo de método de lascamento, e quando relacionada com a matéria-prima analisada, a triagem mostra que os números acompanham a quantidade geral da mesma, ou seja, há mais lascas unipolares e bipolares em quarzto pois o mesmo é a matéria prima mais abundante.

Tanto nos níveis ceramistas como nos pré-ceramistas, foi evidenciada a mesma variação de técnica de lascamento, assim como da matéria prima escolhida, a única diferenciação é em relação à presença de artefatos polidos nos estratos mais recentes, que não aparecem nos mais profundos. Os poucos artefatos lascados são núcleos esgotados que, retocados, foram reutilizados como raspadores, técnica que Miller, já havia mencionado (1992). 


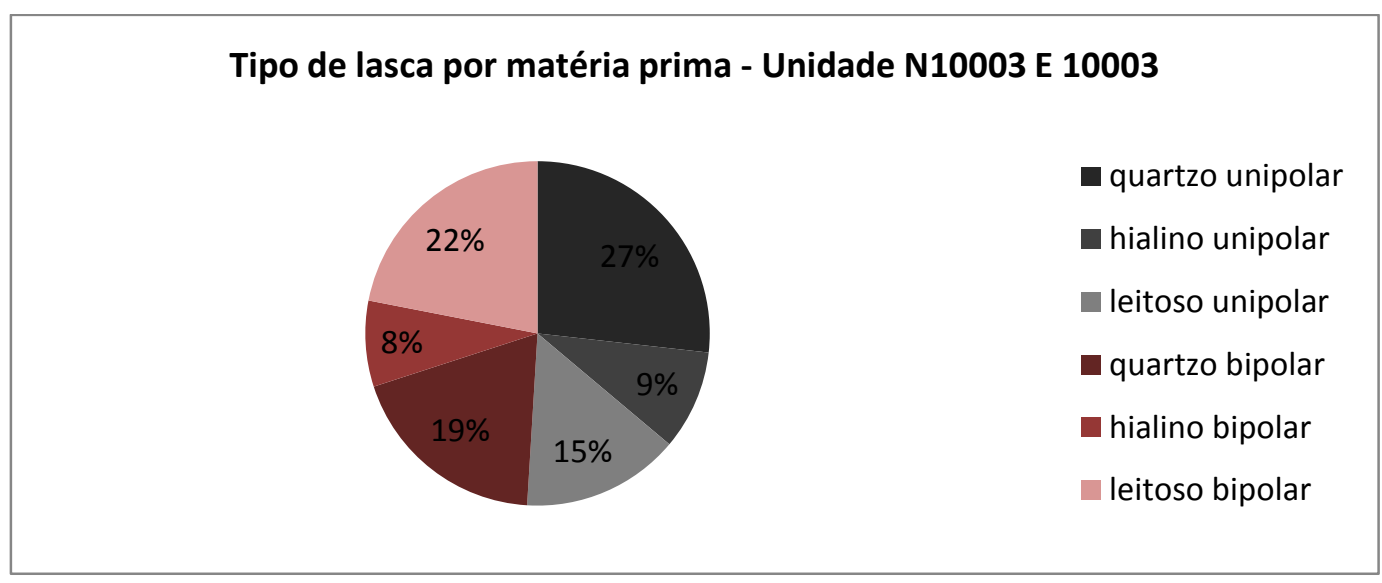

Figura 58 - Tipo de lasca por matéria prima - Unidade N10003 E10003

A partir da análise estratigráfica, e utilizando o atributo "presença-ausência" de fragmentos cerâmicos, podemos definir, nessa área do sítio, a camada pré-ceramista entre os 40 e $110 \mathrm{~cm}$ de profundidade. Uma das preocupações nessa caracterização inicial era perceber se havia uma mudança drástica no único elemento permanente entre as duas ocupações (ceramistas/pré-ceramista), que são os vestígios líticos. Há, em relação inversa à profundidade, uma diminuição do número total de artefatos, e que no estrato ceramista a incidência de lascas e núcleos é visivelmente maior. No entanto, a proporção entre lascas unipolares e bipolares permanece, de certo modo, a mesma, não havendo mudança significativa neste aspecto da indústria em qualquer das ocupações.

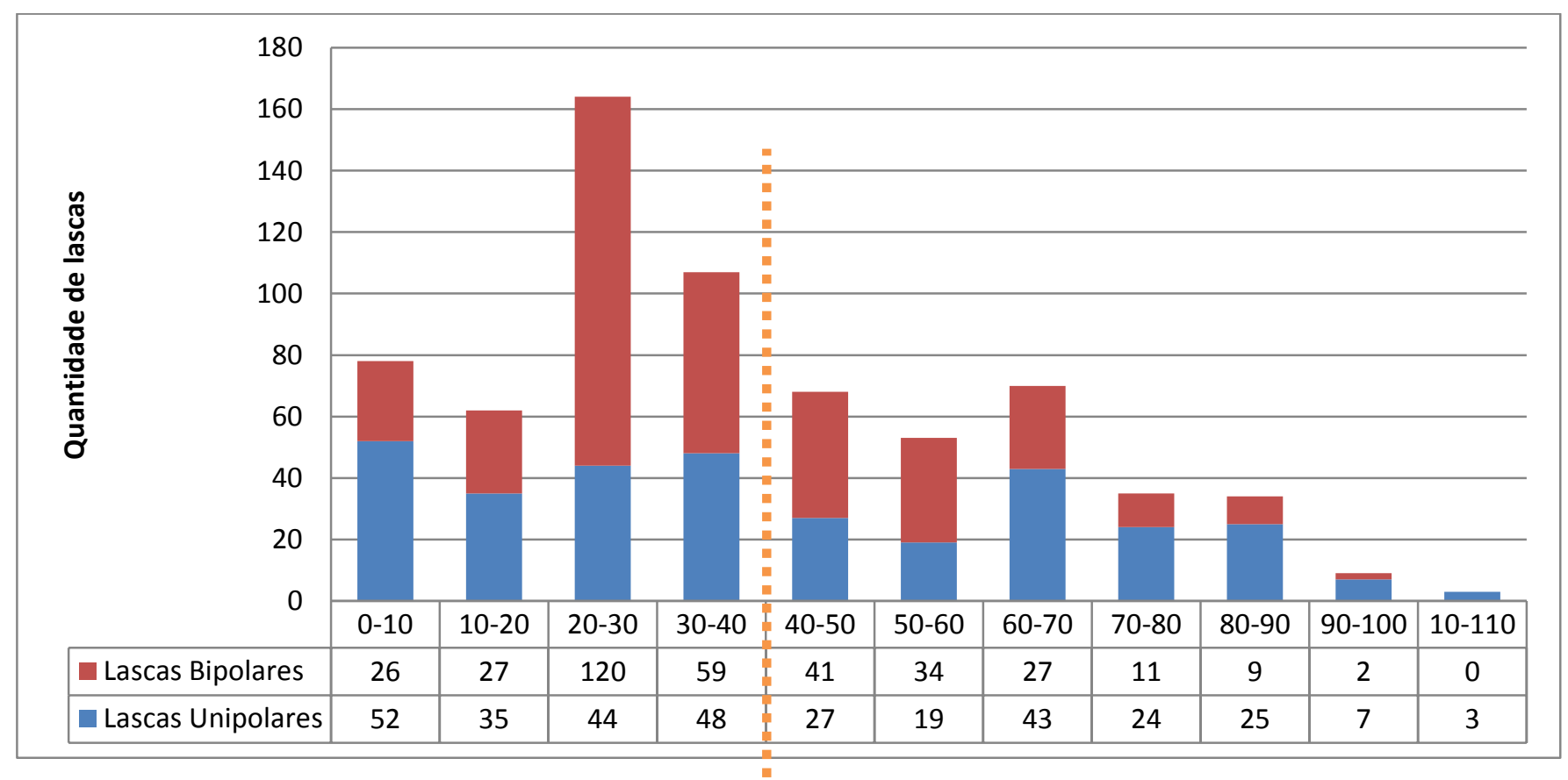

Figura 59 - Quantidade de lascas bipolares e unipolares por nível estratigráfico - unidades N10003 E10003 e N10003 E10004 
Os dados obtidos dessa unidade foram importantes para se poder afirmar que de fato há uma indústria lítica em um contexto seguro de solo antropizado, foi a primeira oportunidade para entrar em contato com o conjunto artefatual pré-ceramista do sítio Teotônio. Embora a análise das peças líticas destas duas unidades não tenha revelado uma quantidade de dados relativamente grande, pode-se afirmar o seguinte:

1- A indústria lítica no sítio Teotônio é composta por artefatos polidos e lascados. Os polidos, relacionados às ocupações ceramistas, são em geral mãos de pilão e machados, produzidos de rochas metamórficas oriundas do local. Os lascados, são produtos de lascamentos unipolares e bipolares de matérias-primas quartzo e suas variações, hialinos e leitosos;

2- Não há, na indústria lítica, uma variação em relação a estratigrafia, a não ser no quesito quantidade, sob uma perspectiva de longa duração, as técnicas de lascamento aparentemente permaneceram as mesmas

\subsubsection{Perfil Leste das Unidades N10030 E9987/ N10045 E9987 e Perfil Norte da unidade N10045 E9987 E9987}

Este perfil, como dito no capítulo anterior, foi aberto com a ajuda de uma pá mecânica, e permitiu observarmos a recorrência contínua de uma especa camada précerâmica, sobreposta pelo estrato ceramista. O perfil Norte da unidade N100045E9987 foi evidenciado em decorrência do alinhamento da linha Leste do dito corte, portanto, é adjacente a ele, e foi escolhido para a realização de amostras de sedimento para análise paleotnobotânica e química inicial.

Em relação às análises arqueobotânicas, os trabalhos são conduzidos pela prof ${ }^{a}$ Myrtle Shock (UFOPA), Emanulla Oliveira (UNIR) e Laura Furquim (MAE). Foi analisada uma coluna de sedimento de $10 \times 50 \mathrm{~cm}$ extraída por níveis artificiais de $10 \mathrm{~cm}$ do perfil exposto na campanha de Fevereiro de 2013, cujo sedimento coletado foi todo 
flotado, de acordo com a metodologia empregada pelos pesquisadores do ArqueoTrop (Silva et all. 2013, Furquim et all. 2013) que busca a recuperação de macro-vestígios, como frutos e seus fragmentos, sementes, tubérculos, madeira, folhas e fibras.

O processamento do sedimento foi feito com o auxílio de uma "máquina de flotação", que separa o material orgânico dos demais vestígios arqueológicos presentes na amostra - como pequenas cerâmicas e líticos - em fração leve e pesada, respectivamente, com menor e maior densidade que a água. A primeira etapa de triagem consiste na separação dos carvões entre lenhosos e não lenhosos - cujos dados quantitativos nos auxiliam a entender a relação entre a proporção de madeira e outras partes de plantas no sítio. Posteriormente, os carvões não lenhosos foram triados entre sementes não carbonizadas, sementes carbonizadas, sementes de Arecaceae (palmeiras) e parênquimas (tecido de preenchimento dos vestígios botânicos. ex.: parte interna da castanha).

A análise dos vestígios encontra-se em andamento, e a identificação das espécies das sementes e dos tipos de madeira evidenciados ainda não foi concluída, mas a triagem inicial,foi feita através de um controle das camadas culturais definidas durantes as escavações e padronizada através de índices de densidade por 5 litros de sedimento.. 


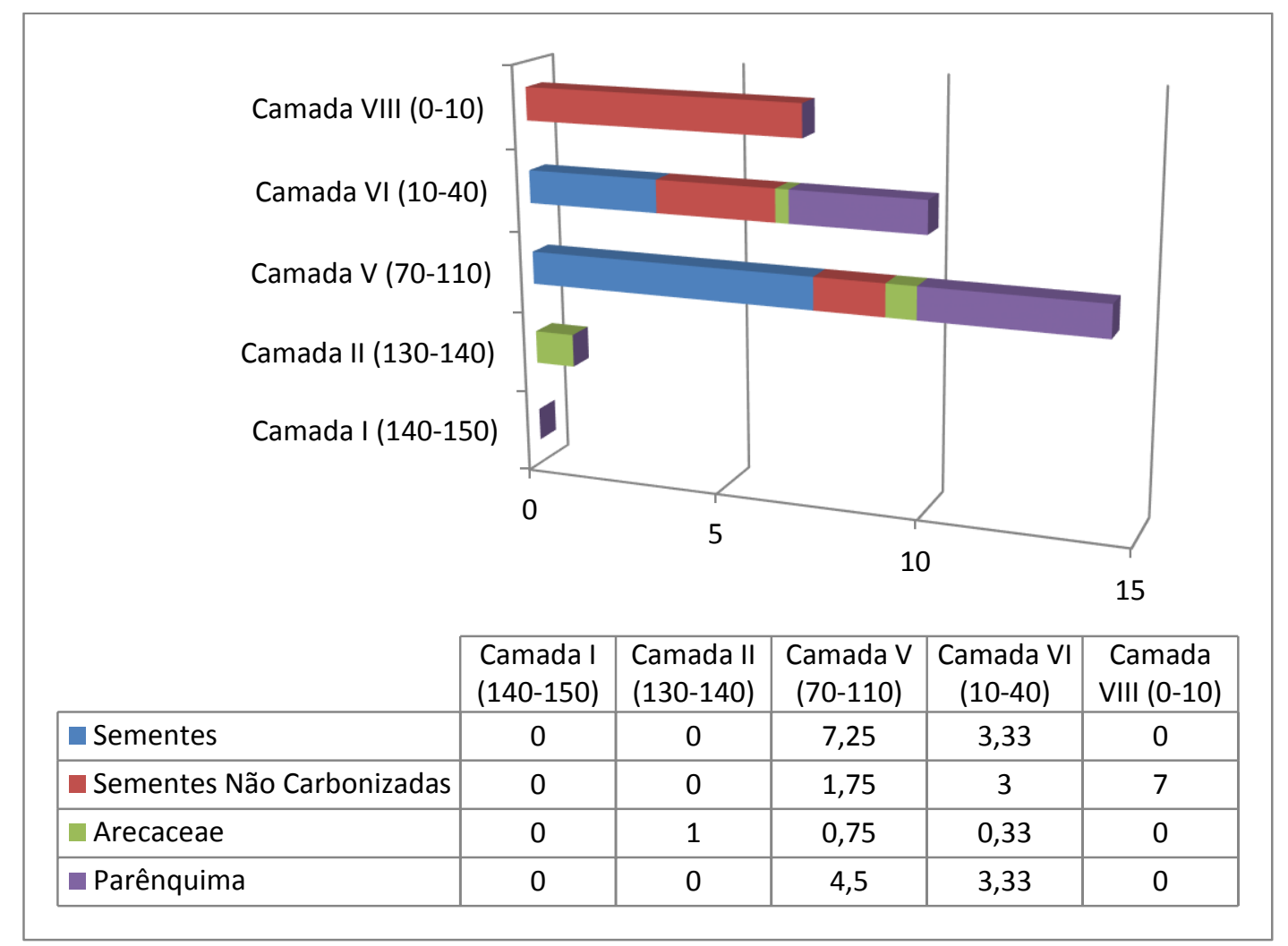

Figura 60 - Gráfico da incidência de Sementes, Sementes não carbonizadas, Arecaceae e Parênquimas por camadas culturais, por 5 litros de sedimento. (adaptado de Furquim et. al 2013)

Pelo gráfico é possível perceber uma presença de elementos botânicos muito superior na camada V, que corresponde a um contexto de Terra Preta Antrópica sem cerâmica, mas com presença significativa de material lítico. Em comparação à Camada VI, claramente um contex to relacionado à ocupação da sub-tradição ceramista Jatuarana, os índices quantitativos aumentam significantemente - em especial se atentarmos à quantidade de sementes não carbonizadas, provavelmente fruto de interferências pósdeposicionais. Não é possível ainda afirmar se de fato as populações mais antigas, préceramistas, possuíam uma atividade mais intensa com as plantas, pois o gráfico corresponde à análise de uma unidade apenas, no entanto, é um indicador inicial para pensarmos os modelos de transição das sociedades ditas caçadores/coletoras para ceramistas/sedentárias, uma vez que, no senso comum, o gráfico deveria indicar uma presença muito maior de atividade botânica nos contextos com cerâmica.

Ainda se atentarmo-nos ao gráfico que inclui a quantidade de carvões lenhosos, as diferenças entre as Terras Pretas Antrópicas pré-cerâmica e relacionada à cerâmica Jatuarana ficam ainda mais evidentes, sendo a primeira mais que o dobro da segunda. 
Estudos mais aprofundados ainda precisam ser feitos, porém, é possível afirmar que as atividades de manejo com o uso de fogo eram também presentes no pacote lítico, com ou sem Terra Preta.

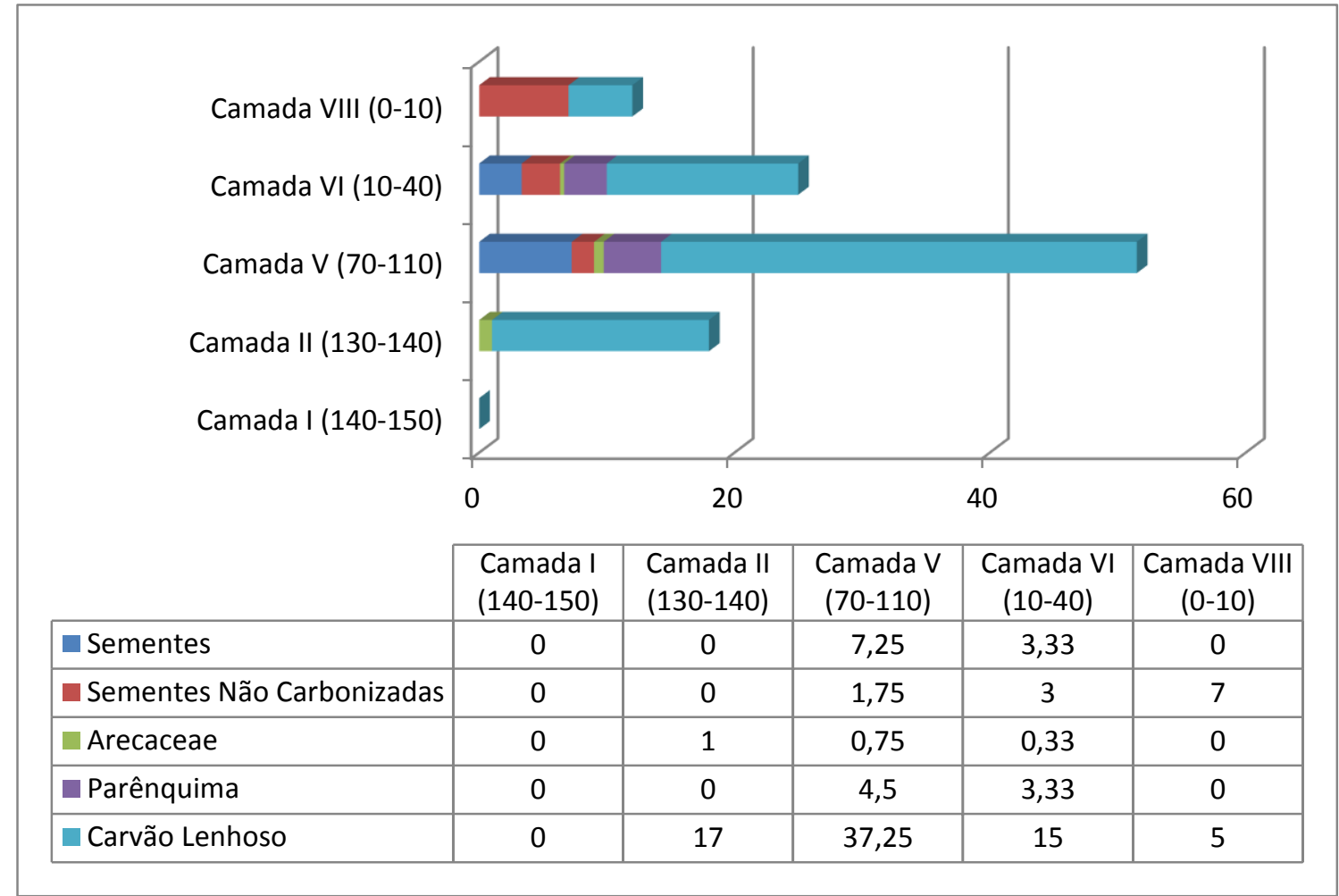

Figura 60b. - Gráfico de incidência de sementes, sementes não carbonizadas, Arecaceae, parênquima e carvões lenhosos por camadas culturais.

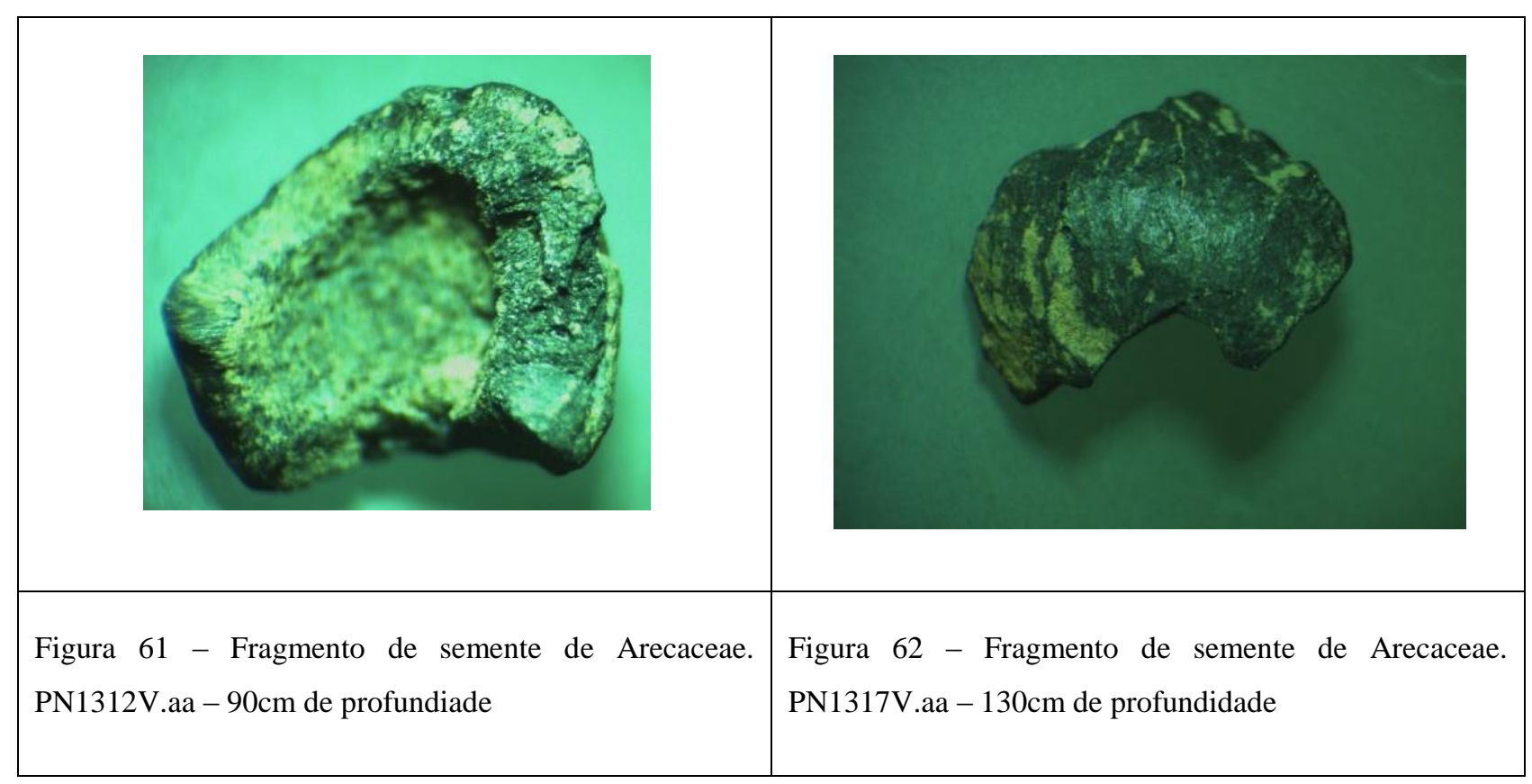




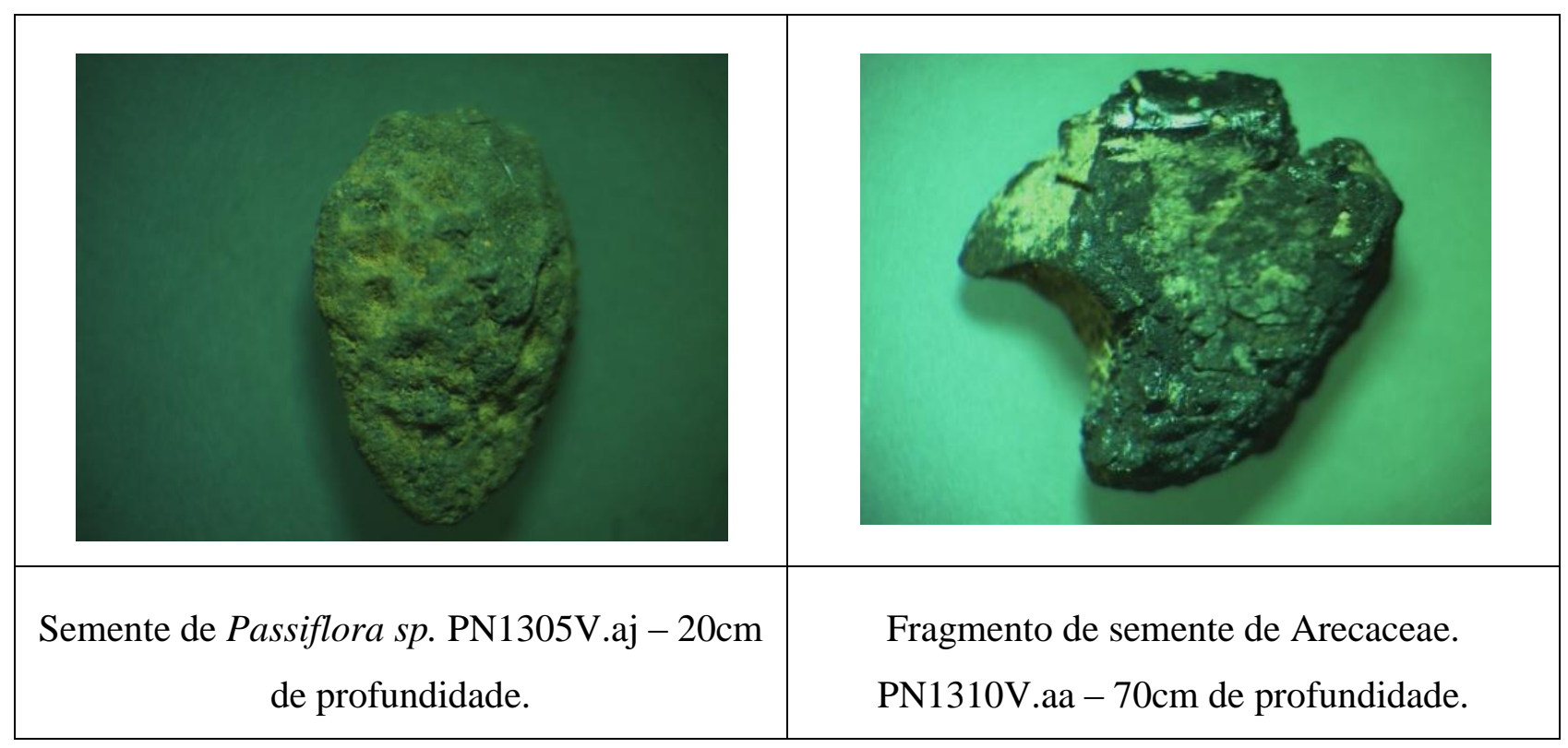

Um dos fatores de atenção nesta região do Estado de Rondônia são os apontamento de Clement et. al. (2015) sobre um provável centro de domesticação da pupunha (Bactris gasipae), sobre o qual não é possível termos novos dados com as amostras coletadas até o momento. Porém, os dados indicam que as Arecaceae já eram presentes na economia pré-colonial do Sítio Teotônio desde, aproximadamente 5.000 A.P

O padrão clássico de oposição entre sociedades caçadoras-coletoras e ceramistas sedentárias recai, justamente, sobre ao aumento da capacidade produtiva destas sociedades e do aumento da interação delas com o meio ambiente. $\mathrm{O}$ surgimento das Terras Pretas, em toda a Amazônia, indica o início desse processo (Neves, 2014) justamente porque são resultado de uma presença perene em um assentamento, somado ao aumento das atividades botânicas, de gêneros cultivados ou não. Os dados inicias sugerem que esse aumento de interação com o meio ambiente, resultante na formação das Terras Pretas, além de ser muito mais antigo, não corresponde exclusivamente à presença de cerâmica, certamente, e talvez de outros elementos que tradicionalmente caracterizam o Período.

Corrobora com isso as análises químicas inicias que foram realizadas de 5 amostras de sedimento do mesmo perfil, e que indicam que determinados índices, como o Fósforo e o Calcio, definidores quando em grande quantidade por excelência do solo antropizado, são maiores na camada pré-cerâmica, no que na superior. 


\begin{tabular}{|c|c|c|c|c|c|c|c|c|c|c|}
\hline \multicolumn{4}{|c|}{ Local: PORTO VELHO } & \multicolumn{4}{|c|}{ Cultura: SÍTIO ARQUEOLÓGICO } & \multicolumn{3}{|c|}{ Data da Análise: $13 / 03 / 2013$} \\
\hline \multirow{2}{*}{$\begin{array}{c}N^{\circ} d a \\
\text { Amosta }\end{array}$} & \multirow{2}{*}{$\begin{array}{l}N^{\circ} \text { do } \\
\text { Lab. }\end{array}$} & \multirow{2}{*}{$\begin{array}{c}p H \text { em } \\
\text { Água }\end{array}$} & \multirow{2}{*}{$\begin{array}{c}P \\
m g / d m^{3}\end{array}$} & \multicolumn{5}{|c|}{$\mathrm{mmolc} / \mathrm{dm}^{3}$} & \multirow{2}{*}{$\begin{array}{c}M O \\
g / K g\end{array}$} & \multirow{2}{*}{$\begin{array}{l}V \\
\%\end{array}$} \\
\hline & & & & $K$ & $\mathrm{Ca}$ & $M g$ & $A l+H$ & $A l$ & & \\
\hline 01 & 086 & 5,7 & 1400 & 0,82 & 41,0 & 4,1 & 181,5 & 0,0 & 39,6 & 20 \\
\hline 02 & 087 & 6,2 & 1640 & 1,36 & 76,3 & 23,4 & 199,7 & 0,0 & 67,2 & 34 \\
\hline 03 & 088 & 6,4 & 1400 & 1,41 & 135,1 & 12,8 & 166,7 & 0,0 & 74,8 & 47 \\
\hline 04 & 089 & 6,3 & 1320 & 1,10 & 191,8 & 5,8 & 170,0 & 0,0 & 55,8 & 54 \\
\hline 05 & 090 & 6,0 & 1510 & 1,77 & 134,0 & 13,9 & 123,8 & 0,0 & 86,2 & 55 \\
\hline
\end{tabular}

Figura 63 - Dados químicos das amostras pedológicas do perfill Norte da unidade N100045E9987

Podemos ver que as amostras apresentam valores altos de Potássio, o que é comum nos índices de Terra Preta. No entanto, é interessante observar comparativamente os dados das camadas 4 (cerâmica) e camada 3 (pré-cerâmica), sendo que a primeira apresenta valores menores de Potássio, Cálcio Magnésio e Matéria Orgânica, mesmo possuindo coloração mais escura. Não são dados conclusivos, mas apontam para uma maior complexificação dos tradicionais aportes conceituais que definem, por exemplo, o Período Formativo e a divisão entre grupos caçadores/coletores e ceramistas/sedentários.

\subsection{Análise dos vestígios arqueológicos da campanha Julho/2013}

Das escavações da campanha de Julho e Agosto de 2013, escolheu-se trabalhar, de formas mais exaustiva, com duas unidades: N10041 E9955 e a N10022 E9882. A primeira, unidade de três metros de Terra Preta contínua, esperava-se ter uma amostra confiável de toda a ocupação cerâmica; e a segunda, de toda a ocupação pré-cerâmica. Já mostramos os problemas que ocorrem no sítio Teotônio que fazem com que esta estratigrafia não seja contínua em todas as áreas do sítio, a idéia aqui é que, analisando estas duas unidades, se tenha uma noção amostral dos processos de longa duração que ocorrem às margens da cachoeira.

Como ponto de nota, vale salientar que, dado a perspectiva colaborativa deste projeto, que sempre contou com a a iniciativa e colaboração do Departamento de Arqueologia da UNIR, parte do material está sob a guarda dessa instituição, sendo 
utilizado em disciplinas de análise de laboratório no curso de bacharelado em arqueologia. Todo o material que foi trazido à São Paulo foi analisado.

\subsubsection{Análise do Material cerâmico da Unidade N10041 E9955}

Unidade N10041 E 9955 foi escavada em área de maior concentração cerâmica do sítio, segundo os dados das tradagens que foram feitas próximas. A camada de Terra Preta Antrópica vai da superfície até a o contato com a rocha laterítica estéril, a $290 \mathrm{~cm}$ de profundidade. A escavação evidenciou um total de 5992 fragmentos cerâmicos, sendo 4015 paredes sem decoração, o que deixa nossa amostra de material diagnóstico com 1977 peças. A incidência de material lítico é diminuta, sendo que não foi evidenciado uma camada clara pré-cerâmica.

\begin{tabular}{|l|c|c|}
\hline & Quantidade & Peso(g) \\
\hline Borda decorada & 200 & 1475 \\
\hline Borda sem decoração & 429 & 1693 \\
\hline Base decorada & 29 & 674 \\
\hline Base sem decoração & 154 & 3726 \\
\hline Parede Decorada & 1155 & 7052 \\
\hline Parede sem decoração & 4015 & 14853 \\
\hline Apêndice & 3 & 18 \\
\hline
\end{tabular}

Figura 64 - Tabela de triagem do material cerâmico da unidade N10041 E9955

Sabendo que o sítio do Teotônio possui uma longa história de palimpsestos, reocupações e alterações antrópicas modernas, a escavação da unidade N10041 E9955 aparenta apresentar um contexto bem preservado, pouco remexido e com diversas camadas de ocupação diferentes. Levantamos duas perguntas que se espera responder 
com a análise dos materiais cerâmicos dessa unidade: a primeira diz respeito à cronologia cerâmica de ocupação do sítio, que pelo estudo de Almeida (2013), é composto de pelo menos dois tipos distintos (embora Zuse (2014) tenha identificado outros conjuntos artefatuais na região do Alto Rio Madeira). A outra questão levantada é sobre a formação da Terra Preta, e para isso espera-se contar com ajuda dos estudos de solo e paleobotanicos, que estão em andamento sob a coordenação de Michelle Tizuka e Myrtle Shock, respectivamente.

Com os dados da triagem, podemos perceber que há alguns picos de densidade de material total, ao redor dos níveis $20-50 \mathrm{~cm}$, outro no $140-150 \mathrm{~cm}$ e um pequeno, porém representativo, por volta dos $200 \mathrm{~cm}$. De profundidade. São divisões que correspondem à análise do perfil estratigráfico feito em campo, e apresentam diferença visível no tipo de material cerâmico.

O gráfico de incidência de material total por quantidade de paredes decoradas mostra que em geral os dois atributos possuem valores que não são iguais, obviamente, mas que aumentos e decréscimos de um não são acompanhados pelo outro, o que seria de se esperar quando se compara a quantidade total de fragmentos com a quantidade de fragmentos de um atributo específico. 


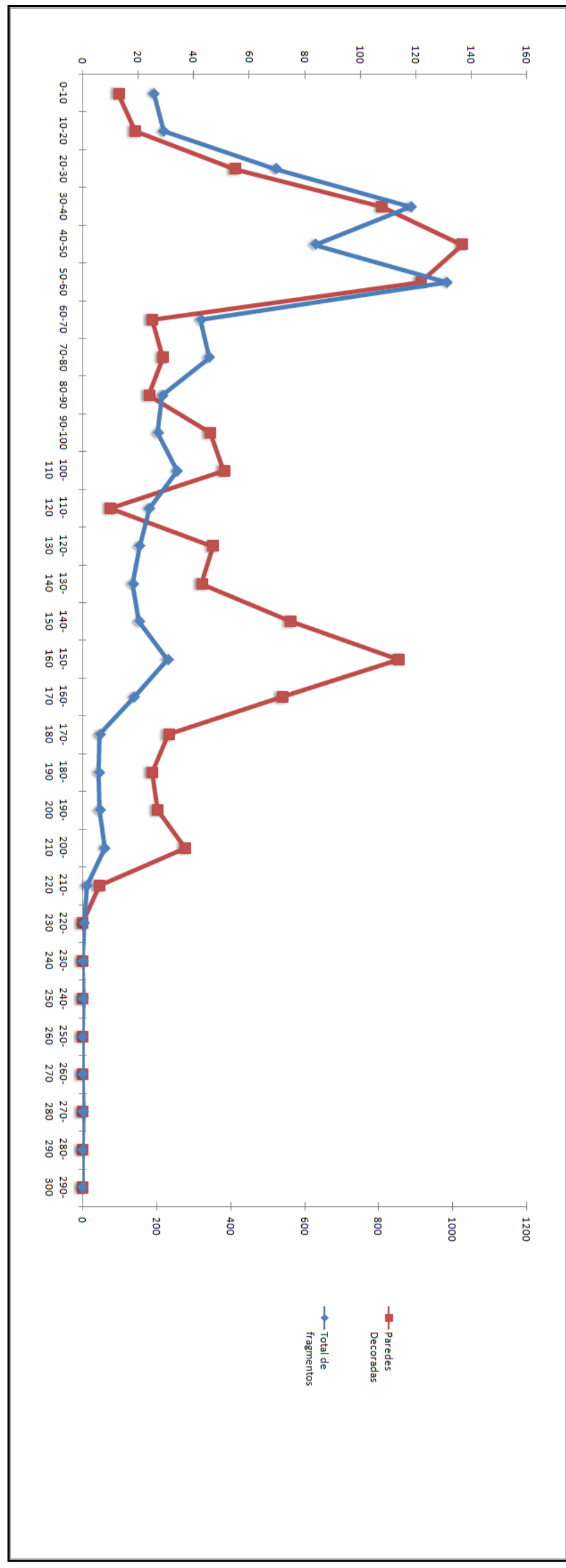

Para ser mais claro, a variação da quantidade de fragmentos cerâmicos totais por nível deveria ser a mesma variação de fragmentos decorados por nível, mesmo que a quantidade dos dois sejam diferentes, que é o que ocorre até o nível 80-90 cm, por exemplo. Estratigraficamente, a partir deste nível, a incidência de paredes decoradas não varia de acordo com o total de fragmentos, indicando níveis artificiais onde a proporção de paredes decoradas em relação ao total de fragmentos é muito alta.

Na foto do perfil, os três picos são representados pela camada VI E (laranja), VI C (vermelho) e VI B (azul). Tem-se como hipótese, portanto, que existam três conjuntos diferentes de material cerâmico, hipótese esta que se pretende testar no decorrer da pesquisa.

Figura 65 - Gráfico e quantidade total de material cerâmico (azul) e paredes decoradas (vermelho) por nível estratigráfico na unidade N10041 E9955. 


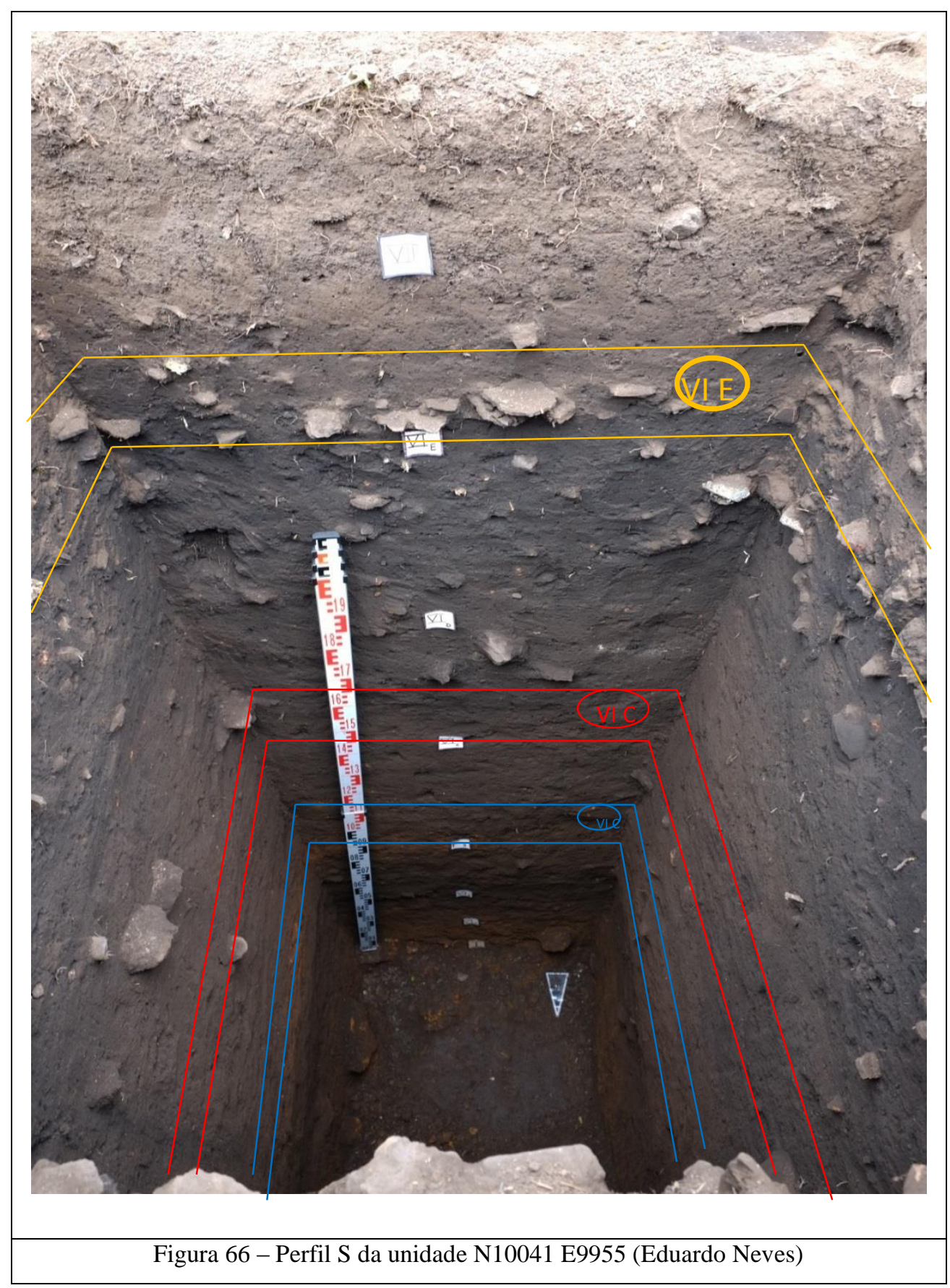

As análises qualitativas do material cerâmico começaram a ser feitas no âmbito do projeto "Curadoria e Análise do Material Cerâmico do Sítio Teotônio", levado a cabo pelo pesquisador Thiago Kater, sob a orientação dos Professores Eduardo Neves e Fernando Almeida. As análises ainda estão em andamento, mas é importante frisar que nesta unidade de escavação encontram-se amostras todas as ocupações ceramistas do sítio Teotônio. A boa preservação do contexto na unidade, localizada na porção Norte da estrada que corta o sítio, é um oásis em meio à inúmeras áreas de retirada de Terra Preta para fins comerciais. A presença de camadas contínuas de cerâmicas diagnósticas, formando claros conjuntos artefatuais, somado à presença de diferentes aglomerados de 
fragmentos estruturados nos permite afirmar que essa área (um quadrado de aproximadamente 50x50m) não foi impactada pelas modernas populações extrativistas da Vila do Teotônio.

A cerâmica da Unidade N10041 E9955, portanto, é um importante marcador para pensarmos as ocupações humanas "pós-líticas", a base da unidade não possui vestígios de Terra Preta sem cerâmica, nem o típico latossolo amarelo, o contexto é de $3 \mathrm{~m}$ de solo antrópico com cerâmica do topo à superfície. Mesmo não havendo um contexto de transição da ocupação antiga para a recente, acredita-se que seja nesse setor do sítio onde encontram-se os vestigios ceramistas mais antigos, mesmo que não haja contato com uma camada pré-cerâmica.

O debate acerca da classificação do material cerâmico foi realizado por mim, Fernando Almeida, Thiago Kater e Silvana Zuse. Aqui, será apresentado um resumo dessa seriação, uma vez que é o objeto de estudo central de outros pesquisadores (Kater, 2014), no entanto, considera-se importante fazer menção aos contextos ceramistas antigos, até mesmo para melhor qualificar as interpretações acerca dos registros arqueológicos do sítio Teotônio.

A análise, portanto, foi realizada utilizando-se da metodologia aplicada com sucesso em outros trabalhos do PALMA (Almeida, 2014, Azeredo, 2010, Kater 2014). Foram analisados apenas fragmentos diagnósticos, ou seja, paredes sem decoração foram deixadas de fora. Paredes decoradas, bordas e bases foram alvos de uma ficha de análise (ANEXO 10) que busca, antes de estabelecer uma filiação cultural, “detectar as escolhas feitas pelos ceramistas durante as várias etapas da produção dos vasos" (Almeida, 2013 pp217). Através da aplicação de uma série de atributos, que envolvem a compreensão da forma do vaso, da qualidade e composição da pasta, dos tipos de decoração, em comparação com a localização estratigráfica de tais vestígios, foi proposta uma seriação inicial, sobre a qual espera-se que os futuros trabalhos se baseiem.

A seriação proposta tem como base, obviamente, os trabalhos iniciais de Miller, nos anos 1970, mas leva em consideração, de forma mais consistente, as recentes produções de Almeida (2013) e Zuse (2014), além da miríade de pesquisas que se adensaram no atual território de Rondônia com a criação do curso de Arqueologia em Porto Velho e com a construção das Hidrelétricas no Rio Madeira, que através do 
licenciamento ambiental propiciaram uma série de importantes resultados para a arqueologia regional (Zimpel Neto, 2009, Suner, 2013, Pessoa, 2015). O cenário das recentes ocupações pré-cabralinas está cada vez mais claro para os pesquisadores, de forma que a consolidação da existência de determinados conjuntos artefatuais cerâmicos está cada vez mais forte.

Almeida, em sua tese de doutoramento, mostrou a abrangência de pelo menos duas fases cerâmicas, a Jatuarana e a Jamari, ao longo da bacia do Alto Rio Madeira e seus afluentes. A sequência estratigráfica que apresenta a fase Jamari como mais antiga, e a Jatuarana mais recente, é recorrente em sítios como Jacarezinho, Associação Calderita e Teotônio.

O trabalho de Zuse (2014) indicou uma variedade de fragmentos diagnósticos aparentemente intrusivos em contextos mais consolidados, como os dois citados. A presença de eventuais conjuntos cerâmicos não preponderantes, representativos de talvez, diferentes formas de interação social, foram levados em conta na seriação apresentada a seguir. No sítio Teotônio, por exemplo, segue uma dúvida em relação aos recipientes inteiros encontrado nas unidades N9947 E10005 e N10022, que aparentemente, por sua posição, na base da ocupação ceramistas, não apresenta semelhança com nenhum outro conjunto cerâmico.

A seriação temporária, portanto, mesmo que baseada na análise do material cerâmico apenas da unidade N10041 E 9955, levou-se em consideração as informações obtidas das campanhas de escavação de 2011 e de Fevereiro de 2013, assim como das outras unidades escavadas concomitantemente à esta. Espera-se que se torne um guia para as ocupações cerâmicas no sítio Teotônio, um sumário que abarque os variados conjuntos cerâmicos, numa tentativa de organizar estRatigraficamente, o grande palimpsesto que se configura à beira da Cachoeira.

A proposta dos tipos cerâmicos, que é resultado de um esforço coletivo dos pesquisadores citados são:

\section{1- Conjunto Jatuarana}

Na Figura 66, corresponde à camada VI E, de coloração laranja. É a variação regional da Tradição Polícroma, possui uma datação para a sua base, de 1200 AP (Almeida, 2013, 
Mongeló, 2014). Foi o principal foco das pesquisas de Almeida, que reconfigurou as datações estabelecidas por Miller (1992), que indicavam uma data antiga, de 700 a.C. Embora haja profundos e antigos conjuntos cerâmicos no Teotônio, a data de Miller se aproxima muito mais das ocupações pré-cermistas.

Profundidade aproximada: $0-30 \mathrm{~cm}$

Características: Temperada com caraipé, possui espessura média entre 0,6 e $0,8 \mathrm{~cm}$. Pouca presença de fuligem. Em geral é bem alisada, mas se comparada com os outros conjuntos presente no sítio, é inferior. O grau de fragmentação do material cerâmico é maior nos níveis superiores. Há uma quantidade considerável de erosões internas, provavelmente causadas por fermentação.

Pasta: varia entre tons de ocre/amarelado (alaranjados) e claros, próximo do branco/acinzentado;

Formas: Predominância de formas abertas, pequenas (menos de 51 de capacidade volumétrica) formatos semi-esféricos ou de calota. Há ainda a presença de algumas flanges labiais (com decorações acanaladas) e carenas;

Decoração Pintada: Presença grande de pigmento vermelho e branco, sendo o nível que mais possui essas decorações pintadas é o $30-40 \mathrm{~cm}$. Em geral, o engobo apresenta-se da cor branca, e a pintura sobre ele da cor vermelha. Salienta-se que há diferentes tons de vermelho. Em alguns fragmentos, há pintura vermelha apenas sobre o lábio das bordas, sem engobo.

Decoração Plástica: Acanalados se sobressaem.

Intrusões: No nível $30-40 \mathrm{~cm}$ possui quatro fragmentos que parecem ser intrusivos, três possuem cauixi na pasta e um possui apenas mineral, sua queima é oxidante, e a pasta é alaranjada (mais clara do que o conjunto Jatuarana). Materiais como esses aparecem em sitios acima da cachoeira do Teotônio, nas ocupações mais recentes na Ilhas da Cobras, São Francisco, Japó e Dionísio. As vasilhas escavadas pela Scientia Consultoria na estrada de acesso a cachoeira do Teotônio possuem as mesmas caracteísticas descritas para esse material intrusivo. 
Observação: Esse conjunto cerâmico foi encontrado em todas as unidades abertas no sítio Teotônio

\section{2- Conjunto Jamari}

Essa fase foi também definida por Miller (1992), e revista por Almeida (2013) e rapidamente por Zimpel (XX). Segundo o primeiro, que a identificou em 96 sítios às margens do rio homônimo, quando das pesquisas de salvamento arqueológico da UHE Samuel, possui datas entre 2500+90 (Beta-22764) e 420 $\underline{50}$ (Beta- 22751).

Almeida a identificou no sítio Jacarezinho, que se localiza no baixo rio Jamari, com uma cerâmica bastante caracterizada pela ausência de decorações, antiplástico de cariapé, banhos de engobo do tipo barbotina e em geral, formas fechadas. As datas obtidas

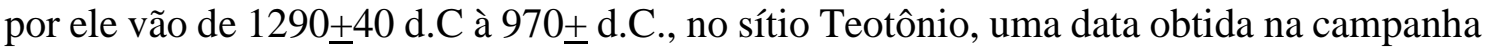
de 2011 correspondente à uma camada de ocupação cerâmica anterior à Jatuarana foi datada em 500 d.C., e Almeida levanta a possibilidade de estar relacionada à fase Jamari. Se as análises confirmarem, seria a datação mais antiga para este conjunto cerâmico na bacia o Alto Madeira.

Profundidade aproximada: $40-120 \mathrm{~cm}$

Características: Temperado com caraipé. É o conjunto com os vasos mais espessos do sítio, entre 0,8 1,0 cm; mas tivemos a sensação de que abaixo dos $100 \mathrm{~cm}$, o material torna-se mais fino. Possui grande quantidade de fuligem. É o conjunto com menor índice de fragmentação, talvez pela grande espessura. Seu alisamento é fino e a queima é aparentemente muito boa. A partir dos $80-90 \mathrm{~cm}$, os fragmentos tornam-se menores.

Formas: Simples e infletidas (suaves), sem ângulos. Parecem ser os vasos, de todos os conjuntos, os que possuem maior capacidade volumétrica. No entanto, abaixo de $80 \mathrm{~cm}$, o tamanho das formas e o volume diminuem. Os fragmentos de tamanho grande parecem indicar a presença de assadores em vários níveis.

Bases: Algumas possuem pontos de inflexão 
Pasta: Varia entre ocre e alaranjado, mas em geral, a cor é homogênea. Ocorrência de fragmentos com coloração acinzentado/escuro.

Tratamento de superficie: Abaixo dos $90 \mathrm{~cm}$, ocorre presença de fragmentos com engobo vermelho, de coloração mais fraca do que a pigmentação Jatuarana. O polimento é perceptível em todo os níveis em que aparecem o conjunto.

Intrusões: Existem alguns fragmentos que destoam da maioria, principalmente em relação à pasta, decoração incisão e apliques modelados) e espessura (mais finos). Aparecem, por exemplo, uma borda com decoração roletada, apêndices aplicados à paredes sem decoração, apêndices do tipo asa no lábio, e um fragmento com decoração incisoponteado.

\section{3- Conjunto Pocó/Saladoide}

A proposta da existência de um complexo cerâmico antigo, semelhante ao Pocó/Saladoide está em debate pelos pesquisadores do PALMA. No entanto, apresento aqui as características que nos fazem pesar neste conjunto cerâmico, primeiro, como possuidor de características distintas dos outros, o que por si só já justifica a sua separação, e segundo, como apresentação inicial desta proposta, do qual o prof. Eduardo Neves possui contribuição considerável junto com os outros nomes já citados.

Conjuntos cerâmicos antigos na bacia Amazônica, tal qual discutido no capítulo que apresenta a definição de Período Formativo, foram estudados desde o início, com destaque para as pesquisas do casal Meggers/Evans. Segundo estes (1983), existiria uma série de complexos cerâmicos antigos nas Terras Baixas americanas que, derivados das sociedades andinas, teriam descido a cordilheira e se dispersado pelas áreas florestadas levando consigo a tecnologia cerâmica, a agricultura, e um corpus ideológico que nos é bastante conhecido. São exemplos destes a tradição Malambo na Colômbia, a tradição Barrancas na Venezuela, a tradição Palo Seco no Caribe e a tradição Borda Incisa na Amazônia brasileira.

A relação entre a cerâmica Borda Incisa e os processos de difusão de novas tecnologias foram reforçadas tanto por Lathrap (1970) como por Heckemberger (2002), que defendem a Amazônia, e não os Andes, como um centro dispersor de tecnologias 
formativas, e a cerâmica barrancóide configurar-se-ia como um dos grandes marcadores culturais desse processo.

Lima (2006,2008, Lima \& Neves2011) debruçou-se de forma mais intensa nessa discussão, compilando diversos dados de seus predecessores, para definir um conjunto Pocó/Açutuba na região da Amazônia Central, na confluência dos rios Negro e Solimões. Para ela, este conjunto é o correlato regional de um horizonte estilístico maior, o Barrancóide, que configura, tal qual afirma Heckenberguer (2006), o indicador principal de uma etapa de inovações tecnológicas e mudanças sociais profundas, ligadas à dispersão de grupos falantes da língua Arawak. Para Lima, esta cerâmica caracteriza-se pela“decoração (que) é feita principalmente com incisões em linhas largas, que definem zonas que são posteriormente preenchidas por incisões finas, paralelas ou cruzadas", são abundantes as flanges labiais, assim como lábios expandidos, e flanges mesiais com decorações incisas.

A cerâmica Pocó, recentemente, também foi estudada e identificada na área do Baixo Tapajós (onde a fase foi definida inicialmente por Hilbert; Hilbert, 1980) por Gomes (2011), que a definiu em linhas gerais: pela presença de cauixi, formas esféricas, bordas diretas e pouca decoração. No Lago Amanã, Costa (2012) também identificou um complexo antigo, com datas ao redor de $2790 \pm$ AP, compatíveis com as datas dos outros sítios da Amazônia. A cerâmica do médio Solimões, onde encontra-se o lago Amanã, apresenta características muito semelhantes às de Santarém e do baixo Tapajós: caraipé como antiplástico, formas com contorno complexo, predominando a ocorrência de flanges mesiais e labiais, sendo estas utilizadas como suportes para decoração modelada, incisa e acanalada. Ocorre, diz ainda C osta, engobo e pintura "em diferentes cores, mas principalmente o vermelho e o alaranjado dispostos sozinhos ou conjugados em faixas finas na superfície externa elou interna das flanges".

Segundo Neves et all (2014), o complexo Pócó-Açutuba configura-se com um conjunto cerâmico padronizado, que é presente em diferentes regiões da Amazônia, e que "seriam os marcadores visíveis mais antigos e disseminados de formas de antropização da natureza e formação de paisagens ao longo da Amazônia". Eles definem a tradição Pocó-Açutuba pelo "uso diversificado de antiplásticos incluindo caraipé e cauixi (..) e formas de vasos complexas", policromia como meio abundante de decoração pintada, uso do preto, vermelho, laranja, amarelo cor-de-vinho e branco, este utilizado geralmente 
como engobo. Decorações plásticas onde se enfatizam as incisões, modeladas, excisões ponteados e escovados, somado a recorrentes modelados zoomorfos aplicados às flanges labiais. Em todos os casos, as ocupações Pocó-Açutuba "representam a base das sequências cronológicas e estatigráficas dos sítios"

Ademais da discussão acerca da Fase Pocó-Açutuba, e a sua relação com a definição do Período Formativo, já foram feitas algumas considerações no capítulo 2, e serão retomadas no seguinte. Segue as características gerais deste conjunto cerâmico no sítio Teotônio.

Profundidade aproximada: $120-230 \mathrm{~cm}$

Características: Os fragmentos mais espessos são bordas, flanges e algumas bases planas. As paredes são em sua maioria mais finas em relação às demais e a queima é muito superior se comparado aos outros conjuntos. Como hipótese, parece que as peças com uma melhor queima são aquelas com decoração. A maior parte dos fragmentos é muito bem alisada, sendo a grande parte polida.

Pasta: Pasta temperada com cariapé, carvões e mineral. A maioria das peças possui uma pasta porosa e leve, enquanto outras têm pasta menos porosa e um tanto mais pesada (nesse caso parece haver menor concentração de carvão). A coloração da pasta é predominantemente clara, com ocorrências de alaranjado, bem como de algumas poucas acinzentadas/pretas.

Formas: Flanges irregulares, com pontiagudos/acastelados e de pontos de inflexão. Predominância de formas abertas e diversas com pequenos volumes - menos de $100 \mathrm{ml}$. A fragmentação do material e a irregularidade das bordas dificultaram a reconstituição de borda, há, por exemplo, bordas aparentemente fechadas, mas que não foi possível a reconstituição. Muita presença de flanges e lábios expandidos, carenas ou pontos angulares presentes. As bases identificadas são planas, mas devido à fragmentação talvez tenha dificultado perceber bases convexas. Há uma base aparentemente em pedestal. Uma base se destacou por um provável furo feito antes da queima.

Decoração Pintada: Pintura de tonalidade branca, e uma alta variação entre os vermelhos, indo do vermelho-alaranjados ao vermelho escuro. Os pigmentos aparecem mais na forma de pintura do que de engobos. Boa parte dessa pintura é delimitada por incisões. 
Decoração Plástica: Principalmente incisões demarcando campos decorativos. Os incisos são muito frequentes, aparecem em linhas duplas paralelas. Ocorrem na face interna da borda/flange, mas há também na face externa, em geral na parte superior das vasilhas. Presença de serrungulados. Na supérficie externa de alguns fragmentos há estrias de alisamento, que por vezes lembram muito um escovado. Um aplique. Fragmentos com ponteados (em um deles, dentro do ponteado, há pintura vermelha - pode ser resquício e não tenha sobrado na parede); carenas em que há ponteado no ponto angular. Nos pontos angulares, independentemente de onde ele esteja, quase sempre delimita uma área decorada. Em geral os incisos e ponteados são feitos com a pasta mais seca (o que a diferencia da Jamari).

\subsubsection{Análise do Material Lítico da Unidade N9882 E10022}

A Unidade N9882 E 10022, diferente da unidade anteriormente apresentada, possui relação inversa à matriz do material arqueológico, uma vez que foi evidenciado apenas camadas estratigráficas pré-ceramicas. Elemento percebível desde a escavação desta unidade foi a total ausência de fragmentos de cerâmica e grande abundância de líticos lascados, de antemão, portanto, o contexto evidenciado nesta unidade foi tratado como essencial para compreender a totalidade dos processos de ocupações humanas na Cachoeira do Teotônio.

Apesar da falta de fragmentos cerâmicos, curiosamente, o local a ser escavado foi escolhido devido à presença de uma borda de forma circular inteira, evidenciada, provavelmente, quando da abertura da estrada. Assim, o objetivo principal dessa atividade, quando começou-se a escavação, era a evidenciação da estrutura de cerâmica, de forma que pudéssemos ter acesso à pelo menos um vaso inteiro, coisa que ainda não havíamos obtido no sítio Teotônio.

Apesar da relativa claridade da cor do sedimento visível na foto perfil, não há dúvida de que este contex to escavado, pelo menos até os $110 \mathrm{~cm}$ de profundidade, tratase de solo antropizado, portanto, dada a ausência de fragmentos cerâmicos, salientamos que estamos lidando com uma camada relativa à Fase Massangana. 
A presença de uma fogueira evidenciada entre os níveis $110 \mathrm{~cm}$ e $160 \mathrm{~cm}$ de profundidade comprovam a ocupação humana, e a sua grande profundidade talvez evidencie mais de uma camada de ocupação pré-ceramista. A hipótese a ser testada é de que esse contexto é de fato um contexto pré-ceramista, antigo, em área não antropizada, que permaneceu relativamente preservado pela presença da vasilha inteira nos níveis superiores.

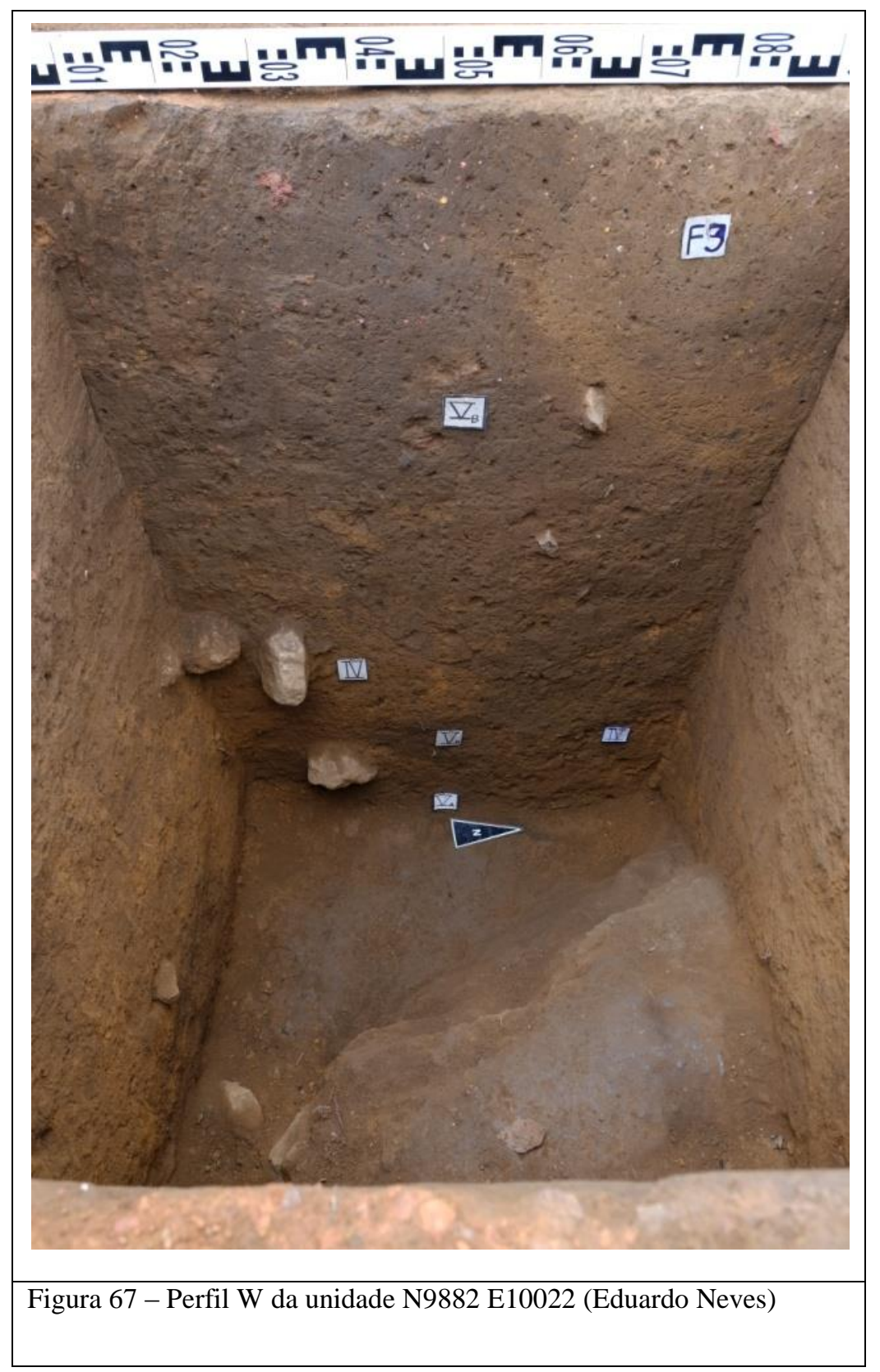

Dessa forma, numa sequência hipotética, ainda carente de comprovação, é como se a estratigrafia da unidade N10022 E9882 fosse a continuação, do perfil estratigráfico da unidade N10041 E9955, que possui a sequência completa das ocupações cerâmicas. Espera-se que, a partir da análise principalmente destas duas unidades, consiga-se 
entender melhor a longa cronologia do sítio Teotônio, compreensão esta que é dificultosa devido ao relativo baixo grau de preservação dos contextos pré-históricos.

O material lítico é o conjunto cultural predominante nesta unidade, com a exceção do vaso cerâmico visível em superfície. O recipiente, que encontra-se provavelmente inteiro, não foi escavado, e permanece, em bloco, no laboratório do Museu de Arqueologia e Etnologia do MAE. Como nenhum outro vestígio cerâmico foi evidenciado nessa unidade, concentramo-nos na análise do material lítico.

Como dito no tópico anterior, a inexistência de fragmentos cerâmicos e a grande preponderância de material lítico caracteriza essa intervenção como uma das mais importantes para o entendimento dos processos de ocupação humana no sítio Teotônio. São raríssimos os locais em sítios a céu aberto na Amazônia em que se encontram contextos pré-cerâmicos em estratigrafias ininterruptas de $1,30 \mathrm{~cm}$ de profundidade, com uma feição ceramista e uma fogueira na base.

Afirma-se, de antemão, que todo o conjunto lítico desta unidade corresponde à ocupações pré-ceramistas, sendo a presença doa vasilha inteira uma intervenção moderna à estas ocupações, uma feição (F6) de grupos ceramistas intervindo contextos antigos. Trata-se, também, de um contexto totalmente antropizado, com Terra Preta até $110 \mathrm{~cm}$ de profundidade, bem preservado, vide as feições e a estrutura de combustão evidenciada.

A análise do material lítico desta unidade deu-se mediante os mesmos termos das unidades anteriormente apresentadas, e escavadas na campanha de Fevereiro de 2013. Aplicou-se uma ficha de análise com o objetivo de: 1) Triar o material arqueológico dos fragmentos de rocha não antropizados, 2) Ter uma idéia geral do conjunto arqueológico dos fragmentos oriundos do lascamento, separando-os por categoria (lasca unipolar, lasca bipolar, núcleos e fragmentos de lasca), por matéria-prima (quartzo policristalino, quartzo hialino, quartzo leitoso, granito ou sílex) e 3) Identificar e isolar os artefatos formais do conjunto, para posterior descrição individual.

Foram analisados um total de 1400 fragmentos líticos, dispostos ao longo dos 14 níveis artificiais escavados. O nível 130-140 não possui material arqueológico, e não foi escavado por completo devido à irregularidade das rochas-base que afloram quando do fim do pacote sedimentar. 


\begin{tabular}{|l|r|r|r|r|}
\hline Nível & Total & \multicolumn{1}{|l|}{$\begin{array}{l}\text { Lasca } \\
\text { Unipolar }\end{array}$} & $\begin{array}{l}\text { Lasca } \\
\text { Bipolar }\end{array}$ & Núcleos \\
\hline $0-10$ & 43 & 34 & 0 & 1 \\
\hline $10-20$ & 87 & 65 & 14 & 8 \\
\hline $20-30$ & 76 & 69 & 9 & 16 \\
\hline $30-40$ & 140 & 54 & 18 & 34 \\
\hline $40-50$ & 317 & 245 & 19 & 53 \\
\hline $50-60$ & 158 & 116 & 14 & 28 \\
\hline $60-70$ & 142 & 112 & 6 & 24 \\
\hline $70-80$ & 143 & 106 & 8 & 29 \\
\hline $80-90$ & 124 & 90 & 8 & 24 \\
\hline $90-100$ & 68 & 48 & 4 & 16 \\
\hline $100-110$ & 28 & 21 & 1 & 6 \\
\hline $110-120$ & 17 & 11 & 1 & 5 \\
\hline $120-130$ & 57 & 44 & 5 & 8 \\
\hline Totais & 1400 & 1015 & 107 & 152 \\
\hline 68.156 & & & & \\
\hline
\end{tabular}

Figura 68. Tabela do índice de lascas por nível da unidade N9882 E10022

A maior parte do material é composto por lascas unipolaress, de tamanho diminuto, muito semelhante aos dados apresentados nas unidade N10003 E10004 e N10003E10003. Em relação à quantidade de material lítico, há um pico generalizado entre os níveis $30 \mathrm{~cm}$ e $60 \mathrm{~cm}$, abaixo estratigraficamente da vasilha inteira, que foi retirada com $35 \mathrm{~cm}$ de profundidade. Acredita-se que esta não tenha tido um impacto tão grande na distribuição do material lítico, e a sua presença só poderia fazê-lo diminuir, e não acumular-se sob o mesmo, o que nos dá segurança para dizer que se trata de um momento de adensamento das atividades de lascamento. 


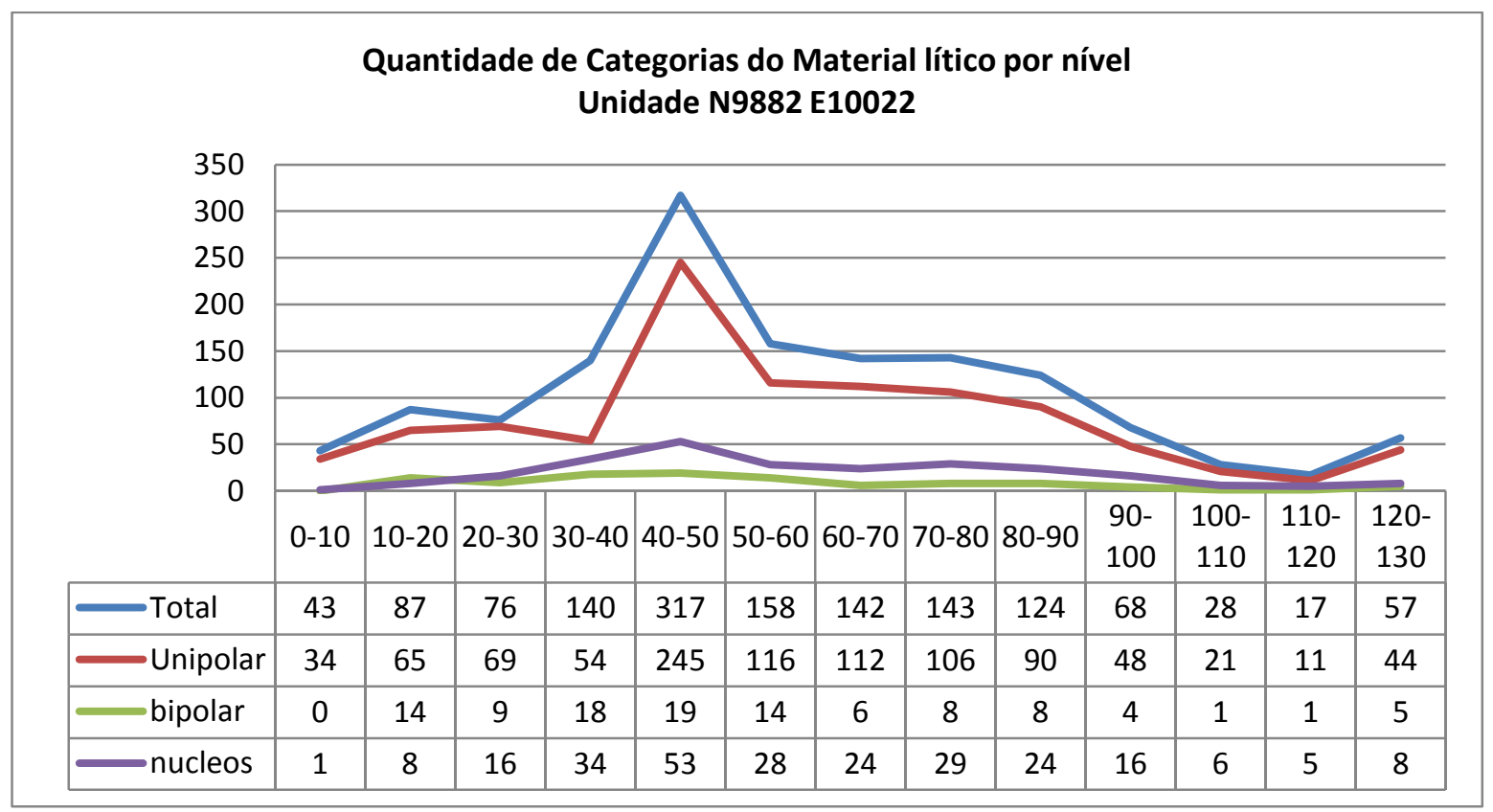

Figura 69: Quantidade de Categorias do material lítico por nível - Unidade N9882 E10022

Em relação à categoria predominante, é possível perceber que o lascamento unipolar foi utilizado como preferência nesta área do sítio. O lascamento bipolar aparece, em geral, com lascas corticais, brutas, oriundas de pancadas fortes com percutores consistentes que geralmente esmagam o talão. As lascas unipolares, bastante diminutas, parecem ser em sua maioria do tipo de retoque, no entanto, a falta de instrumentos formais, como a literatura assim os define (Prous, 1990) impossibilita que os caracterizemos assim. Lascas de retoque são as últimas etapas do processo produtivo de ferramentas líticas, em geral, obtidas através da técnica de pressão, com um percutor leve, de madeira ou osso, estas tem como função dar forma ao gume e definem o bordo ativo. Seria uma ótima explicação se houvesse uma variedade grande de artefatos com negativos destas, no entanto, inexistem, nesta ou em qualquer outra unidade.

A predominância das lascas unipolares neste contexto parece ser um dado novo para a análise das indústrias líticas da Amazônia, que em geral carregam o estigma de possuírem pouca matéria prima de tamanho considerável, tornando a técnica bipolar a única opção para a obtenção de lascas através do apoio em uma plataforma fixa, causando um contra-impacto quando da batida sentido cima-baixo e baixo-cima. A técnica bipolar, como dito, parece ter sido utilizada apenas para o descorticamento, no entanto, acreditase que esta talvez seja uma assertiva ainda um tanto quanto insegura para se fazer, dada as deficiências de atributos na ficha aplicada. 


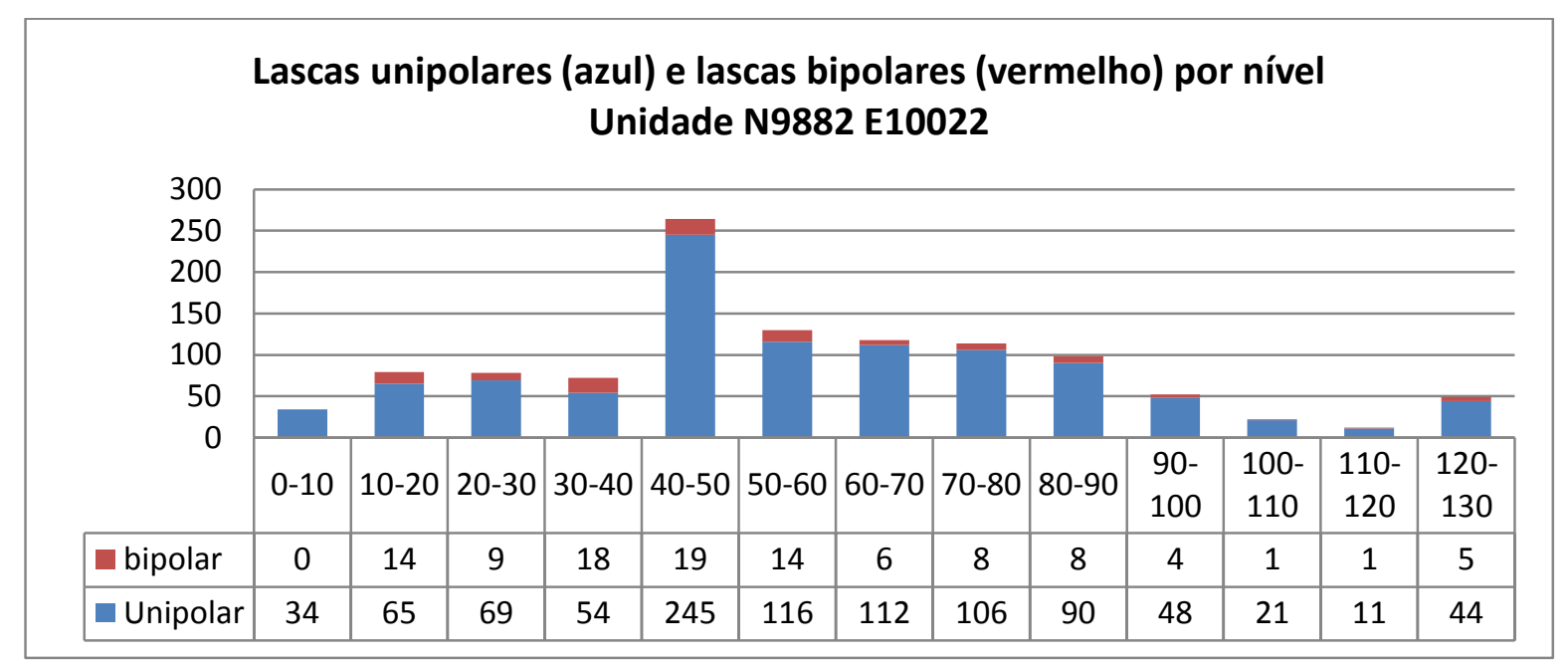

Figura 70: Variação da quantidade de lasca unipolares e bipolares por nível - Unidade N9882 E10022

Em relação ao tamanho do material, como dito, há uma grande predominância de lascas de diminutas, que variam, de forma igual, entre menores de $1 \mathrm{~cm}$, e entre $1 \mathrm{~cm} \mathrm{e}$ $2 \mathrm{~cm}$. Vale ressaltar que esses dados são correspondentes apenas a lascas em que foram identificas talões e em que se é possível estabelecer a técnica de lascamento. Fragmentos de lascas foram apenas contabilizados

O tamanho diminuto das lascas reflete o tamanho dos núcleos também, que são pequenos se comparados à industrias líticas de regiões tradicionalmente estudadas no país. A matéria prima, como descrito anteriormente, é provavelmente oriunda de veios de quartzo que afloram por entre as rochas metamórficas das áreas de cabeceiras de igarapé. O tamanho das lascas e artefatos é, portanto, reflexo das limitações da matéria-prima utilizada por estas populações. 


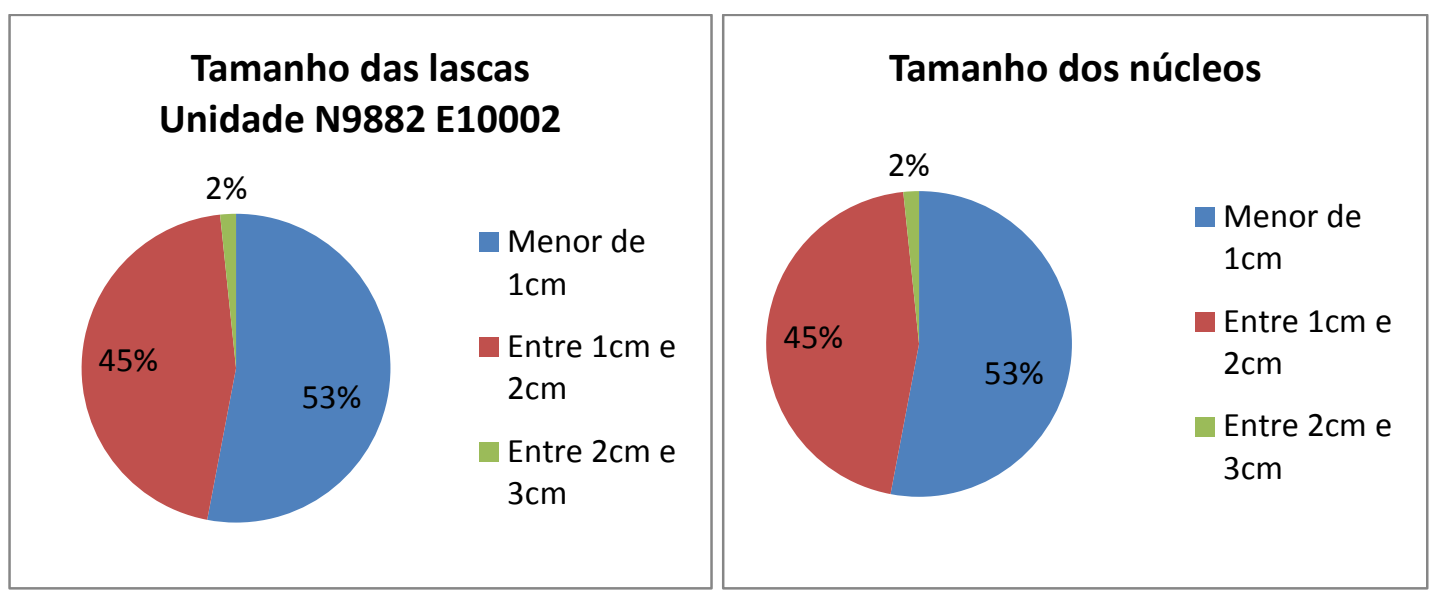

Figura 71:Gráficos de tamanho de lascas e de tamanho de núcleos - Unidade N9882 E10022

Os núcleos, embora não tenham sido alvos de uma análise diacrônica qualitativa, apresentam as mesmas características dos que foram analisados em 2013. Não apresentam, em geral, mais do que dois planos de percussão, e a utilização através da técnica bipolar é predominante. Núcleos esgotados de formato esferoide, como indicados por Miller (1992) foram reutilizados como raspadores laterais, aproveitando-se das arestas dos negativos da retirada das lascas.

Os artefatos evidenciados são caracterizados, em sua maioria, por lascas unipolares com retoques em suas porções distais, de formato subparalelo, orientados em um só sentido. Existe a preferência por lasca de adelgaçamento, sem a presença de córtex, que se somam aos já citados núcleos esgotados reutilizados como raspadores.

Foram evidenciadas três lascas unipolares de artefatos polidos, a 10, 40 e $100 \mathrm{~cm}$ de profundidade. Parecem indicar, primeiro, que já se estava utilizando a técnica de polimento de rochas para a conformação de artefatos muito antes do aparecimento da cerâmica e, em segundo lugar, que tais objetos estavam sendo reutilizados como plataformas para a fabricação de novos instrumentos.

Em linhas gerais, os artefatos líticos da Unidade N9882 E10041 são caracterizados por uma indústria expedita, sem grande formalidade na sua confecção. Não parece haver um padrão claro, nem em relação ao formato dos artefatos, ou aos retoques, que hora parecem ter sido feitos sob pressão e hora sob pancada unipolares, deixando negativos com ângulos abruptos. Especula-se que esses artefatos possuam uma função de manejo de bens orgânicos, de trabalho com madeira e vegetais, uma indústria que preza pelo fabrico imediato de bordos ativos para corte e raspagem. A pouca robustez das lascas 
retocadas e a grande variabilidade de tamanhos encontrados não nos faz pensar que se tratam, por exemplo, de dentes de raladores, como os encontrados em outras regiões da Amazônia (Perry, 2002).

\subsection{Discussão dos dados}

O sítio Teotônio apresenta uma característica singular no cenário da arqueologia regional, e de certa forma, no contexto pré-cabralino da Floresta Tropical. São diversos os elementos que, com o desenrolar das pesquisas entre os anos de 2011 e 2014, nos surpreenderam positivamente pela complexidade do registro e pela possibilidade de obtenção de novos dados que pudessem contribuir para as narrativas históricas do Alto Rio Madeira.

O principal questionamento que nos fazíamos, quando da primeira ida ao sítio, era em relação à sobreposição de diversas ocupações distintas às margens da Cachoeira do Teotônio. Almeida (2013) deu indícios de que o registro arqueológico no sitio Teotônio era formado por um palimpsesto que abarcava diferentes ocupações desde o Holoceno Médio, até os dias atuais (Mongeló \& Almeida 2014).

A compreensão do sítio Teotônio em sua totalidade de ocupações foi uma preocupação que se esperava resolver-se com três atividades primordiais. Primeiro, com a abertura sistemática de unidades de escavação, de forma que se pudesse obter dados bem controlados de profundidade e localização do material arqueológico; e parte dessa atividade foi realizada na campanha de Julho/Agosto de 2013. Em segundo lugar, para compreender a relação entre a Terra Preta antropogênica, e a presença de uma camada unicamente composta por materiais lascados, foi proposta a abertura do perfil de $15 \mathrm{~m}$ de largura, expondo um corte amplo no barranco já impactado, atividade realizada na campanha de Fevereiro de 2013. E finalmente, a fim de se obter dados gerais acerca da dispersão do material arqueológico, tanto em profundidade como em sentido longitudinal, foram realizadas as intervenções com cavadeiras-manuais, as tradagens, na última campanha de escavação. 
A somatória do resultado destas três atividades, os dados obtidos através destes, nos possibilitaram compreender, primeiramente, o conjunto de possibilidade de camadas, estas arqueológicas ou não, Como apresentado no capítulo anterior, existem oito camadas que são encontradas, nunca de forma contínua, nas diversas estratigrafias do Sítio. A configuração desses dados é de extrema importância, uma vez que o sítio sofreu e sofre com inúmeras ações de antropização recentes, desde a época da construção da Vila do Salto Grande, da construção da estrada de acesso à BR-364, e a retirada constante de Terra Preta para fins comerciais ilegais.

O resultado quantitativo das tradagens nos mostra, a primeira vista, que os locais de aglomeração de material lítico pré-cerâmica não corresponde exatamente aos pontos de abundância de fragmentos cerâmicos. A dispersão do material cerâmico no sítio é muito mais homogênea e contínua, fragmentos cerâmicos são presentes em quase todas as intervenções que realizamos. Com as tradagens, foi possível separar as camadas de Terra Preta que possuem apenas material lítico, referenciando-as espacialmente, tal qual o mapa de densidade cerâmica.
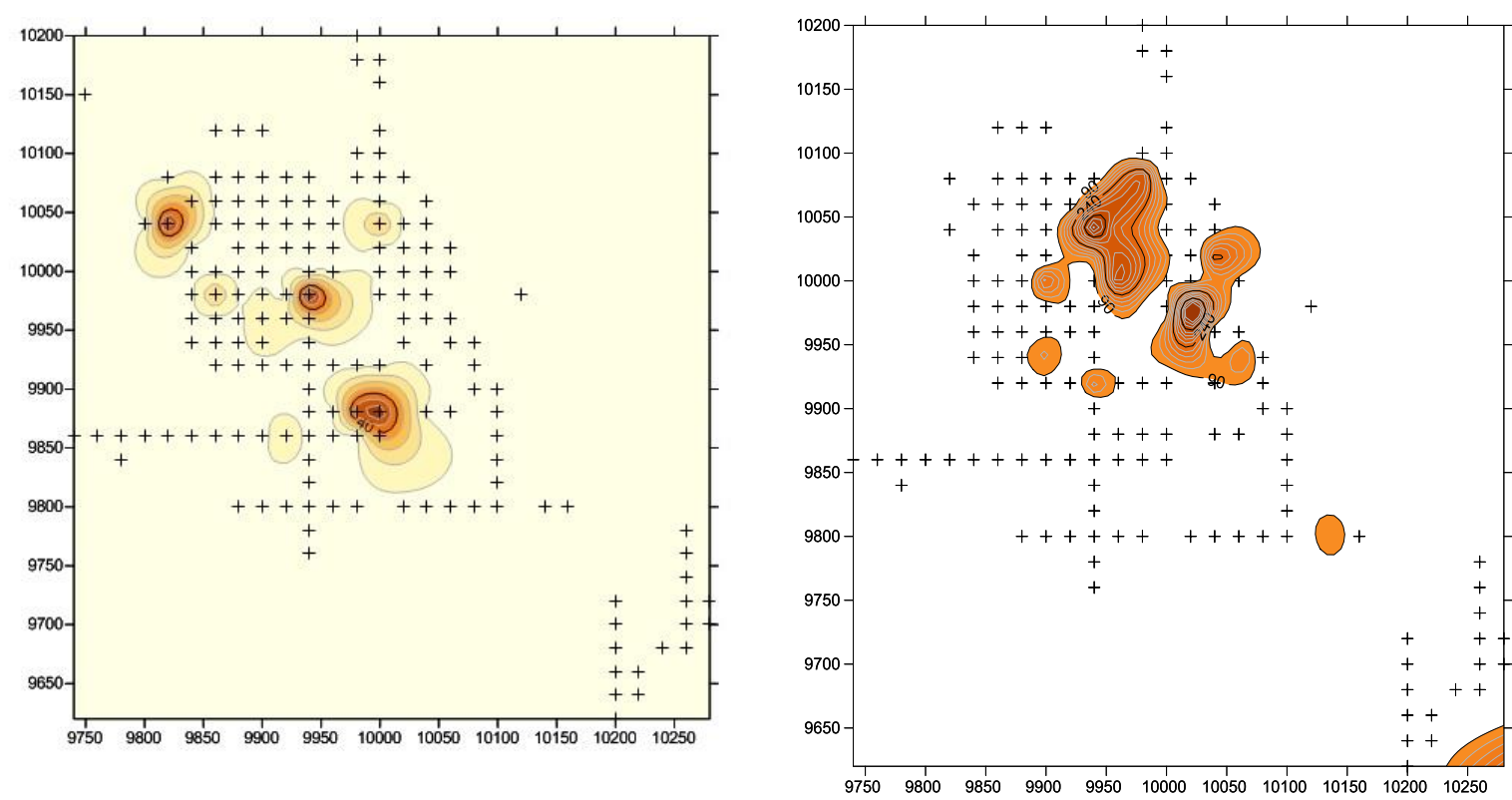

Figura 72 - Mapas de dispersão de material lítico (Massangana) e de dispersão do material cerâmico no sítio Teotônio

Pode-se notar, portanto, que as áreas de presença dessas camadas da fase Massangana não são totalmente contínuas, e que os picos de quantidade e material lítico não são necessariamente os mesmo dos cerâmicos. Isso corrobora, mais uma vez, para a 
existência inquestionável de um contexto antrópico não-ceramista, mais antigo, e pode servir de base para inferências, ainda que muito inicialmente, sobre áreas de uso e locais de assentamento.

Compreender essa variedade de camadas não foi um exercício fácil. Só em relação à indústria lítica, a vemos presente em três diferentes contextos: com material cerâmico em solo antrópico, sem material cerâmico no solo antrópico, e sem material cerâmico em solo "natural". Miller (1982) já havia nos alertado sobre a presença de um contexto précerâmico abaixo do estrato Massangana, denominado por ele como Complexo Girau.

O Complexo Girau é o contexto mais antigo da bacia do Alto Madeira, está relacionado ao período do Holoceno Inicial, sua descrição mais detalhada encontra-se na Introdução. De fato, encontramos vestígios de uma fina camada de latossolo amarelo, na unidade N9882 E10022, com grande presença de material lítico lascado, destacando-se inclusive da curva normal do gráfico de quantidade por nível.

Essa camada, de líticos lascados presente em solo de tipo latossolo, encontra-se abaixo da estrutura de combustão retirada em bloco, e imediatamente sobre as matrizes rochosas que recobrem o platô da Cachoeira. O material lascado, tecnologicamente, não apresenta diferenciação em relação aos demais vestígios encontrados na mesma unidade, nos níveis superiores, destacam-se as lascas unipolares de tamanho diminuto, em sua maioria de quartzo policristalino; foi evidenciado, ainda um artefato do tipo raspador lateral, que encontra-se melhor descrito nos anexos.

A descrição que Miller faz do material relacionado ao Complexo Girau é tão pobre quanto esta apresentada, talvez, pelas mesmas limitações, poucas intervenções, e pouco material, suas datações são também relativas. No entanto, sabemos que foi comum, no Alto Madeira, Miller criar fases não só pensando no conjuntos artefatuais, mas no contexto em si, o caso da Fase Massangana é exatamente isso. O caso do Complexo Girau não é diferente, nas escavações de Miller nos anos 1980, ele identificou um contexto lítico abaixo das camadas de Terra Preta, o diferenciou, não pelas características tipológicas dos artefatos, mas pela disposição do contexto, em comparação com a estratigrafia.

No caso da unidade N9882 E10022, a situação é semelhante. Temos, com segurança, uma camada de Terra Preta com a presença de líticas lascados (CAMADA V), mas temos também, pelo menos $10 \mathrm{~cm}$ de solo não antropizado, sob uma fogueira bem 
estruturada, com grande quantidade de lascas, e pelo menos um artefato. Talvez seja cedo demais para afirmar que há um antigo complexo pré-ceramista de idade próxima ao Holoceno Inicial, necessita-se de maiores intervenções, no entanto, são indícios para se começar a pensar a ocupação humana inicial na bacia do Alto Madeira.

São poucos os indícios de ocupações pré-ceramistas relativas ao Holoceno Inicial, e os dados apresentados ainda são muito incipientes para afirmar que se trata de um conjunto artefatual que corresponde a uma unidade cultural, uma fase ou um complexo, pois além da presença/ausência de solo antrópico, não há outros elementos que assegurem a diferença do que há, estratigraficamente acima dos $120 \mathrm{~cm}$ de profundidade e do que há abaixo, uma datação, eventualmente, resolveria bem esse problema.

Em relação à datação destes contextos, obtivemos da camada $\mathrm{V}$, um pouco acima desta, uma data que nos leva a crer que é muito provável que haja vestígios mais antigos dos que foram seguramente datados. A data do Holoceno Médio (6500 AP) insere-se em um quadro cronológico na bacia do Alto rio Madeira que se expande historicamente, os dados levantados pelos trabalhos de arqueologia de contrato na área da Cachoeira de Santo Antônio (Zuse, 2014) mostraram que há contextos antigos do mesmo período nessas áreas do trecho encachoeirado, também com camadas de Terra Preta enterradas e sobrepostas a pisos cerâmicos, como é o caso do sítio Garbin;

Ainda que falte uma análise mais minuciosa dos contextos pré-cerâmicos escavados no âmbito do licenciamento ambiental da UHE Santo Antônio, os dados parecem indicar uma correlação semelhante de contextos, e tal qual Miller havia previsto, o Teotônio e sua Terra Preta antiga, sem cerâmica, não parece ser uma ocasionalidade.

Acredita-se que, no sítio Teotônio, tenha havido uma população estável e antiga, que desde pelo menos o Holoceno Inicial já manejava de maneira intensiva o meio ambiente, resultando na produção de solo antrópico, com um padrão de mobilidade talvez reduzido, e uma economia variada entre fontes vegetais, que os dados paleoetnobotânicos parecem indicar, e proteína animal oriunda da abundante atividade piscosa.

Há um debate grande acerca da presença de sociedade caçadoras-coletoras em ambientes amazônicos, que envolvem questões ecológicas de profundas implicações teóricas (Lee,1982; Beiley, 1989; Colinvaux \& Bush 1991, Gnecco \& Mora, 1997) das quais não seja talvez o momento de adentrar. Com o avanço das pesquisas arqueológicas 
no Holoceno Amazônico, cada vez mais percebemos as características peculiares desse sistema natural. É impensável, hoje em dia crer em grupos humanos portando os costumes e as formas de adaptação das planícies norte-americanas, ou da Europa Central, em um local de tanta abundância proteica como a Floresta Tropical. Roosevelt (1996) já nos mostrou que havia, desde o Holoceno Inicial, um uso constante de elementos botânicos na dieta destas populações, que o tradicional aporte metodológico de definição de sociedade caçadoras-coletoras talvez necessite de uma reformulação no caso Amazônico. O sítio de Penã Roja também é um bom exemplo, Gnecco e Mora (1997) mostraram um uso intensivo de elementos botânicos das populações do Holoceno Inicial (9000 AP), onde $68 \%$ dos vestígios botânicos eram oriundos de palmeiras.

Não se adentrará nesse debate, no entanto, a evidência de um contexto de solo antrópico datado do Holoceno Médio em um ambiente de várzea amazônica vem a corroborar para essa perspectiva, e esperamos que alguém faça esta discussão com melhor qualidade. Ingold $(1987,1996)$, por exemplo, crê que o conceito de caçador-coletor não explica a totalidade das dinâmicas destas sociedades, pois serve unicamente como definição dicotômica à da de agricultor/pastoril, suas contribuições à crítica da "ecologia humano-evolutiva" talvez tragam elementos para a questão da definição do elemento econômico dessas sociedades.

Em relação aos dados iniciais obtidos da análise cerâmica a existência de uma camada representante da Tradição Pocó/Açutuba (2014) nos coloca um paradigma interessante. Esse contexto, o Pocó-Açutuba, é visto pela literatura como início do processo em que se gestaram tecnologias novas como a cerâmica, a agricultura e o manejo intensivo de recursos naturais, ou seja, é a representação por excelência do Período Formativo nas Terras Baixas. Gomes (2011) faz essa associação de forma mais direta, estudando os conjuntos cerâmicos Pocó do baixo Tapajós, ela utiliza-se dos conceitos clássicos de Ford e Meggers para definir a tradição.

No Teotônio, portanto, teríamos então dois conjuntos artefatuais que corresponderiam ao Período Formativo, a Fase Massangana, definida por Miller, e a Tradição Pocó/Açutuba. Não que isso seja incoerente com o que Steward ou Jorge Marcos defendiam como caracterização desse período, tanto que o mesmo foi subdividido inúmeras vezes por diversos pesquisadores, e com diferentes nomenclaturas: Formativo Inicial, Tardio, Médio, Incipiente, Proto-Estado, etc. 
Sob essa ótica, o lógico seria afirmar que os dois conjuntos, o Massangana e o Pocó/Açutuba seriam representativos de um mesmo processo, que possui uma caracterização mais complexa, onde recai sobre ele movimentos e impulsos de intensidade distintos. Em um momento inicial teria se gerido as bases econômicas para a configuração da Terra Preta, no Holoceno Médio, e posteriormente, por motivos não muito claros, a cerâmica teria aparecido como elemento agregador a este processo fértil de florescimento social.

Pois bem, o caso do Alto Rio Madeira é interessante também, pois até agora é o único lugar onde o conjunto Pocó/Açutuba se apresenta estratigraficamente junto à uma ocupação pretérita, estável e antiga. Nos locais onde ele foi diagnosticado (ver imagem capitulo 1), a cerâmica com a Terra Preta aparece como a primeira evidência humana ou, depois de um grande hiato de descontinuidade temporal, como é o caso da Amazônia Central (Costa, 2008) e do Médio-Baixo Amazonas (Neves et all., 2014)

Seria o caso de, identificado os dois complexos, caracterizar um Formativo Inicial e outro Tardio? Consideramos tal proposta uma incoerência com o que apresentamos no capítulo 1. O fato de termos essa recorrente confusão na designação, da caracterização desta etapa periódica só revela, mais uma vez, sua incapacidade de explicação enquanto elemento orgânico, auto-definido, de qualquer processo que seja. Se o processo é o mesmo, a lógica é que ele seja refletido em sua concepção material em apenas um contexto, é esta a função da periodicidade histórica, estabelecer parâmetros qualitativos para explicar o mesmo processo em diferentes lugares e tempos. No Alto Madeira, mais do que em qualquer outro lugar, o Formativo não parece ser uma categoria classificatória satisfatória para a compreensão desse processos.

Com os dados que temos, até agora, acreditamos que é possível afirmar que:

1- O sítio Teotônio é composto por um palimpsesto de ocupações humanas, que vão desde $6500 \mathrm{AP}$ até os dias de hoje, comportando diferentes formas de relações sociais que deixaram impressas estas especificidades nas mais diversas formas de cultura material

2- Que o início destas ocupações talvez tenha se dado ainda durante o Holoceno Inicial (Complexo Girau), e durante o Holoceno Médio estas populações 
iniciaram um processo de intensificação do manejo do meio ambiente, resultando no aparecimento das Terras Pretas (Fase Massangana);

3- A existência dessas ocupações humanas no Holoceno Inicial e Médio se dá pela presença de um indústria expedita de lascas de quartzo, que primava pela obtenção de simples gumes retocados através de retiradas de micro-lascas unipolares. Eventualmente, lascas unipolares podem ter sido utilizadas como ferramentas de corte, no entanto, os estudos apresentados não são suficientes para afirmar;

4- Existe um complexo cerâmico antigo, relacionado à Tradição Pocó-Açutuba, que antecede outros dois conjuntos cerâmicos mais recentes, a Fase Jamari e a Fase Jatuarana. Quando do aparecimento dos conjuntos cerâmicos, aumenta-se as manchas de Terra Preta sobre o platô, e aparentemente, as áreas de utilização do espaço tornam-se mais amplas e contínuas;

5- A Terra Preta continua sendo um interessante marcador de intensidade do manejo das fontes naturais, do adensamento populacional e de estabilidade de assentamento. No Sítio Teotônio, temos um contexto firme que a relaciona à populações pré-ceramistas, que possui sua base em 6500AP e seu topo em 3000 $\mathrm{AP}$, uma das datações mais antigas para esse tipo de evidência em sítios à céu aberto nas Terras Baixas da América do Sul. 


\section{CAPÍTULO 5 - Há História sem Formativo?}

Formas de divisão dos tempos históricas existem muitas. São calcadas em pressupostos contemporâneos, que, aplicados às narrativas históricas, configuram unidades temporais representativas de determinados processos e que possuem uma coerência no exercício anacrônico do entendimento do desenrolar do desenvolvimento das formas de organização social.

Dividir os tempos históricos não é só uma ferramenta, é uma estratégia que possui ligação íntima e próxima à concepção epistêmica do cientista, enquanto produtor de narrativas históricas. Só há sentido em realizar uma segmentação dos períodos históricos se o historiador o compreende de uma maneira totalizante; sabemos que o homem saiu das cavernas e hoje mora em grandes conglomerados urbanos. A mesma espécie foi capaz de viver durante milênios de anos de economias baseadas na caça e na coleta, no forrageio e na pesca, hoje desenvolve-se de maneira avassaladora subjugando liberdades individuais, promovendo a fome e a morte deliberada de parte da população. É de extrema importância pensar que esse processo não é linear, mas sim produto de um longuíssimo processo de desenvolvimento histórico de determinadas categorias da sociedade que estabelecem um restrito conjunto de possibilidades com as quais os seres humanos possuem capacidade de escolha.

Não vivemos no capitalismo à toa, existe uma razão histórica para que este seja o sistema que defina nossa sociedade, tampouco, houve total liberdade das sociedades atuais em optarem pelo desenvolvimento desigual das mesmas. Tal qual o capitalismo define, em diversos atributos, as capacidades de atuação de distintos corpos sociais, a eles sucederam-se outras formas de organização sócio-político-econômicas que explicam, em determinado ponto, o surgimento destas forças produtivas capitalistas. 
Isto quer dizer que a história possui um sentido, ela não é o conjunto aleatório de eventos e processos que ocorreram, de forma randômica, no tempo e no espaço. Há de ter uma coesão nesse emaranhado de fragmentos do passado que explique, de fato, a conformação social em que vivemos nos dias de hoje. Se hoje, há inegavelmente, um conjunto coerente de atributos que definem nossa sociedade (capitalista) como o campo econômica, político ou social, entender as configurações que caracterizam as sociedades passadas que, em determinada forma, explicam a nossa, é um devir epistemológico.

A seriação dos tempos históricos é exatamente esse exercício. Nem o mais positivista dos científicos do século XIX, ou o mais visceral histórico-culturalista, ao procurar estabelecer parâmetros de classificação de sociedades ou formas de organização social, estão imbuídos de neutralidade absoluta. Estão invariavelmente, e de forma intencional, procurando uma lógica para o desenvolvimento das sociedades que possam dar sentido a este momento em que então estão vivendo.

O historiador nunca está absorto nos tempos históricos do passado, sua produção de conhecimento é reflexo direto da sua vivência contemporânea, da sua posição social, da sua trajetória acadêmica, da sua posição na geopolítica mundial. Os arqueólogos dinamarqueses que definiram, desde os intentos primordiais, idades pré-históricas, estavam olhando profundamente para a Europa do final do século XIX, assim como Steward e Kroeber que estabeleceram periodizações vivenciando o New Deal norteamericano dos anos 1930, por exemplo. Identificar esses elementos na construção da narrativa histórica desses arqueólogos é um desafio para a reconstrução dos conceitos por eles aplicados, ainda mais no tocante da periodização histórica, que no caso da arqueologia, parece possuir uma fluidez fora do normal.

Muito antes de nós já fizeram tal análise com tão grande maestria (Shanks \& Tilley 1988, McGuire, 2008, Trigger, 2009) que não cabe, talvez, delongar aqui. O intuito dos capítulos iniciais foi, sucintamente, traçar o caminhar do conceito de Período Formativo e de Revolução Neolítica durante o século XX, buscando compreender as diferenças 
epistemológicas entre estes, e as implicações teóricas que a aplicação de tais toponímias trazem consigo, apesar da aparente fantasia ferramental.

Diz-se fantasia pois, como foi mostrado, a periodização histórica configura-se como uma ferramenta tão antiga quanto a análise sistemática dos eventos pretéritos. Explicar as relações sociais e as conformações político-econômicas de nossos antecessores foi o real sentido da construção de narrativas históricas durante muito tempo, e hoje, com o avanço dos debates epistemológicos, é possível olhar para essa produção científica com o grau crítico necessário para compreender que as tais ferramentas foram e são instrumentos precisos de formulação de determinada teorias que fazem sentido quando confrontadas com a pergunta explicitada mais acima: "como chegamos aqui?"

Mostramos que a cristalização do conceito Formativo possui raízes profundas no evolucionismo social, na antropologia norte-americana da primeira metade do século XX, em uma concepção de cultura orgânica e limitada. Ao mesmo tempo, foi possível perceber que é também fruto de uma série de debates teóricos, entre difusionistas e especifistas , entre formalistas e substantivistas (Polanyi, 2013) e, no pós-guerra, entre históricoculturalistas e Processualistas. Essa concepção de seriação dos períodos históricos, no entanto, apesar dos intensos debates, das vacilações classificatórias de Steward, das contradições de definição de Whilley e Phillps (1956), das incertezas de Meggers e Ford, diz respeito a uma única concepção epistêmica. E é a isso que precisamos nos ater.

Intensos foram os debates entre o que é o Formativo, apresentamos os mais significativos, os que tiveram mais repercussão na comunidade acadêmica, e principalmente, os que são acessíveis aos pesquisadores aqui deste renegado centro periférico de produção de conhecimento. Há pelo menos 100 anos o termo Formativo aparece corriqueiramente nas publicações arqueológicas, com linhas fluídas e com limites difusos, no entanto, ele permanece. Tal qual a Idade Média de Le Goff (2008), ele foi ampliado e reduzido, re-caracterizado e repaginado, porém, sua concepção permaneceu, em grande medida, intacta. 
É a epistemologia da concepção da seriação histórica que diferem, profundamente, o período Formativo da Revolução Neolítica. Falamos disso rapidamente no capitulo 1, mas é importante voltar a pontuar. Tentar igualá-las (estas duas definições), como muitos já o fizeram na América, só reforça a concepção generacionista e evolutiva das própria existência do Período Formativo. A tradição acadêmica que definiu o que é Revolução Neolítica é distinto dos autores que embasaram a criação do conceito de Período Formativo, suas diferenças se dão na perspectiva funcional de aplicação do método, tanto o materialismo dialético como o social-evolucionismo possuem o intuito de qualificarem as explicações acerca das sociedades contemporâneas, mas distinguem-se no ponto de vista teleológica desta produção de conhecimento.

O que significa classificar uma sociedade como pertencente ao Período Formativo? Qual a implicação, na nossa sociedade contemporânea, compreender que houve "culturas formativas" em nossos atuais territórios? Estas são as perguntas que se deve fazer ao analisar a concepção dos conceitos classificatórios empregados, pois não trata-se de uma simples taxonomia cientificista, a classificação não explica-se por si só, tampouco respeita leis universais. Esse exercício só faz sentido se aproximarmos a causalidade da nossa realidade.

A crítica epistêmica à modelos hegemônicos na arqueologia bebeu, sem dúvida alguma, de maneira considerável nas teorias da História moderna. Os trabalhos de Shanks \& Tilley (1989) e Ian Hodder (2007) são bons exemplos de como a produção arqueológica vem desconstruindo essa visão holística da história.

As correntes pós-processualistas na arqueologia são a iniciativa de maior fôlego no debate acerca da concepção do conhecimento histórico. As publicações de Shanks e Tilley de 1987 e de 1998 são considerações de peso no que tange à crítica hermenêutica com ênfase na interpretação pessoalizada. Admite-se que suas assertivas sobre a caracterização das epistemologias evolucionista estão corretas, porém como solução, apresentam um caminho errado. 
Estão certos pois identificam o caráter social dentro de uma corrente teórica que tem por princípio o desatrelamento dos campos científicos e políticos. Direcionam o debate aproximando a concepção evolucionista de história com o positivismo cego. A concepção histórico-culturalista de formulação de períodos ou eras históricas, dizem eles, é o reflexo clarividente de uma noção evolucionista da história, carregada com todos os aspectos que o tradicional corolário crítico comumente aponta, de forma acertada, sobre tal teoria.

Os exemplos apresentados tanto de Steward como de Ford mostram que a noção de história destes arqueólogos é unilinear, possui juízo de valor de superioridade e inferioridade, de desenvolvimento e de barbárie. Mostramos que essa noção de evolução social possui raízes profundas nas teorias colonialistas e higienizadoras do século XX, que justificaram a ocupação europeia na África e que consolidou o caráter imperialista nas Américas e na Ásia.

Os pós-processualistas (Shanks \& Tilley, 1987) estão também corretos ao afirmarem que a ideia de evolução social está próxima da concepção da "fillosofia positivista", corrente muito popular no século XX. A perspectiva questionada é de que as sociedades humanas se desenvolveram através de um caminho unilinear e irrevogável, calcado na inexorabilidade da evolução social, caminho presente no desenvolvimento positivo das ferramentas e técnicas de produção. A possibilidade de analisar a história através de um determinado número de leis que expliquem de forma "verdadeira "e científica" os processos sociais e as mudanças culturais, por exemplo, conflui com a perspectiva de inevitabilidade histórica. Uma vez que só há um caminho a seguir, há apenas uma forma de compreendê-lo.

As críticas que se faz, com cada vez mais frequência, a esse determinismo monocausal que se expressa na utilização do conceito "Formativo", vem muito sob a ótica da funcionalidade da produção de conhecimento. A identificação da impossibilidade de neutralidade perante a ciência abriu um campo de estudo do entendimento mais profundo 
das razões, algumas vezes escusas, que embasam a perspectiva de determinação de estágios culturais-evolutivos. É dizer que quando os arqueólogos que definiram os diferentes estágios do Período Formativo estavam fazendo isso não apenas por imposição do registro, mas porque possuíam uma perspectiva positiva de evolução social que desemboca sempre em algo melhor, na busca dos grupos humanos se organizarem em sociedades estatais, por exemplo.

Pecam, no entanto, os pós-processualistas, na apresentação de uma saída estratégica para uma compreensão de diferente tipos de processos históricos. A crítica pós-processual apresenta acertadamente as contradições do modelo evolucionista social, no entanto, não consegue, devido às suas limitações epistêmicas, apresentar um modelo de explanação da história do desenvolvimento humano de forma alternativa (Gosden, 1999).

A concepção que a literatura (Heidegger, 1972) consagrou como "círculo hermeneutico" é o caso encontrado comumente nas críticas apresentas a utilização do Período Formativo. A ideia parte do pressuposto de que a ciência deve ser revolucionada nela mesma, questionando, desde a sua concepção de status de produtora de conhecimento verdadeiro, e dando grande ênfase ao papel da interpretação como elemento que permite ao cientista, ai sim, uma visão total das diferentes concepções de narrativas históricas.

Shanks \& Tilley (1987), por exemplo, dizem que a "interpretation thus seeks to understand the particular in the light of the whole and the whole in the light of the particular". Para eles, a capacidade de interpretação na arqueologia é o processo que possibilita a aproximação dos dois campos que são referência ao arqueólogo, o passado e o presente. A "saída estratégica" a impossibilidade de neutralidade científica é, do seu ponto de vista, uma análise mais profunda dos discursos, identificando que há diferentes formas de se constituir as narrativas históricas, atreladas estas à diferentes concepções sistêmicas. A multivocalidade, assim, aparece como um elemento intrínseco ao campo 
científico da história, e caberia ao historiador, enquanto pesquisador consciente da dialética objetividade-subjetividade, identificar as contradições nos discursos e entendelos a partir e suas especificidades.

Essa perspectiva de produção de conhecimento científico coloca, em primeiro lugar uma carga subjetiva à construção das narrativas históricas. Entender que cada discurso é um discurso, e que possui elementos valorativos distintos, que correspondem à corpos ideológicos descaracterizados, individualizados, levou os arqueólogos ligados a essa corrente construírem interessantes críticas aos discursos hegemônicos na arqueologia, no entanto, suas afirmações acerca da construção do conhecimento histórico esbarram na relativização total de todas estas vozes (Diaz, 2008; McGuire \& Navarrete, 1997).

No entanto, como aponta Díaz (2008), o pós-modernismo, ao adotar um relativismo "cultural baseado "na desconstrução de metarrelatos para a análise da uma micro-história, na qual o indivíduo é o motor da mudança social", incorre no erro de desacreditar na história como ciência válida e útil às dinâmicas sociais contemporâneas. Ou seja, a crítica pós-moderna, calcada na perspectiva da interpretação e dos problemas teóricos da conceituação não colabora para o desenvolvimento da arqueologia enquanto ferramenta universal de mudança histórica. A noção de multivocalidade, resultado dessa crítica epistêmica à construção de discursos, desconstrói, primeiro o expertise do arqueólogo, e segundo, coloca em cheque qualquer contribuição que os resultados das pesquisas arqueológicas possam ter (Gnecco, 1999).

Não é intento aqui desenrolar mais a respeito das implicações da corrente pósmoderna na arqueologia, e as críticas à ela. No entanto, é necessário pontuar para que o leitor compreenda que, ao debater o conceito de Formativo, não estamos desqualificando pura e simplesmente esta concepção histórica, acreditamos que há um desenvolvimento das sociedade humanas que é calcado em determinados aspectos que são compreensíveis, analisáveis e científicos. Shanks e Tilley, ao construírem a crítica, e 
ao nosso ver, a mais contundente até aqui, sobre a utilização da conceito de Período Formativo e Neolítico (ver cap 2), propõe que o giro epistêmico se dê na concepção de história, na raiz da construção narrativa, no discurso pelo discurso. De que serve o estudo da história, portanto, se as narrativas são inconfrontáveis, se à ciência não há função?

Ao nosso ver, ao criticar o conceito de Período Formativo, não deve-se jogar com a água do banho, o bebê. Não é porque há certos erros conceituais que, quando confrontados com a realidade, colocam em cheque a conceituação do Formativo, que se faz necessária a inutilização de ferramentas de periodização históricas. O desafio do arqueólogo, enquanto historiador, é a construção de pontes entre elementos que são passíveis de serem analisados e comparados através do tempos, que façam sentido à propriedade explicativa dos fenômenos sociais, estes históricos.

No nosso entendimento, a teoria cumpre uma função heurística, que permite uma aproximação racional e sistêmica dos processos recorrentes das relações sociais. Ela deve compreender a sociedade em sua concepção substantiva, encarando a realidade como resultado dos processos históricos. As formações sociais possuem qualidades fundamentais que a designam e estabelecem parâmetros dos quais a movimentação social dos mais diversos componentes dessa sociedades possuem capacidade de se movimentar. Quando dizemos que uma sociedade caçadora-coletora não pode ter um sistema político estatal, por exemplo, quer dizer que há determinados elementos holísticos nas formas de organização social que são qualitativos na caracterização das mesmas, elementos como a economia, a ideologia, a política, concretizadas nas relações de propriedade, trabalho, meios de produção, etc. Quer dizer, também que há determinadas limitações na dialética dos campos que conformam estas sociedades, no caso, uma forma de relação extrativista dos recursos naturais, como as dos caçadores-coletores clássicos, não comporta uma estrutura estatal, justamente porque existem elementos que nos permitem olhar para sociedades estatais e para sociedades caçadoras-coletoras, compará-las e concluir que são diametralmente opostos. (Bate 1987). O que faz com que vejamos que estas sociedades 
são distintas é justamente a capacidade de compararmos elementos analíticos que possam ser estudados em ambas as conformações sociais, é o que dá sentido ao processo histórico.

O caso da crítica à conceituação do Formativo na Terras Baixas Sul-Americanas é semelhante. Desconstruir seu conceito e não procurar compreender as formas de recorrência nos processos de organização social que se sucederam e que conformam a situação atual das sociedades indígenas seria um pecado metodológico. O intento desse capítulo será, de forma geral, debater um pouco sobre a forma com que a antropologia vê esses processos de transformação nas sociedades ameríndias, e lançar luzes à proposta de incorporação do conceito de Modo de Produção de Parentesco (Wolf, 1982) na periodização da pré-história amazônica.

\section{1-As Terras Baixas e o Modo de Producão de Parentesco}

Segundo Lee (1999), quem formulou pela primeira vez o conceito de sociedade caçadora-coletora foi Willian Sollas, em 1911, com uma perspectiva bastante calcada nos grupos contemporâneos, estes comunidades tradicionais marginais que não possuíam suas atividades alimentares calcadas predominantemente no cultivo de espécie domesticadas. $\mathrm{Na}$ arqueologia, o conceito tornou-se bastante popular na América do Norte, tendo sido utilizado por Boas (1966) em suas classificações taxonômicas, e foi replicado consistentemente tanto por arqueólogos ligados ao particularismo (Kroeber 1925), como por Steward (1938), que possuía uma perspectiva de ciência mais nomotética dos processos históricos.

Na década de 1960, Elman Service (1971) promoveu uma discussão acerca das formas de organização de grupos caçadores-coletores, colocando algumas questões ao modelo incialmente proposto por Steward. Este, por meio de estudos etnográficos, formulou uma divisão das sociedades caçadoras-coletoras em bandos patrilineares, 
bandos matrilineares e bandos compostos, este último consiste em várias famílias endogâmicas. Para ele, a concepção que definiam estes grupos era calcada basicamente no aspecto econômico, primordialmente, na forma de obtenção de recursos, e em segundo plano, comparativamente em relação à formas de interação inter-populacional, que é configurada na divisão dos bandos de acordo com as relações familiares.

Para Service, os bandos patrilineares erma a forma mais pura da organização humana na América pré - contato, pois do seu ponto de vista, os bandos compostos eram resultado da interação destas comunidade originárias com os europeus. Lee (1968), mais tarde, afirmaria que "caçadores-coletor" acabou virando um sinônimo da definição de Steward.

Lee \& De Vore(1968) realizaram importantes contribuições ao modelo de forrageiro, e o resultado do simpósio por eles impulsionado em 1968 teve, inclusive, uma das primeiras publicações acerca das sociedade caçadoras-coletoras no ambiente Amazônico (Latrap 1968). Lee define cinco principais características que são percebíveis em sociedade caçadoras-coletoras: 1- Igualitarismo, 2- Baixa densidade populacional; 3Ausência de territoraliedade; 4-estocagem mínima de alimentos e 5- fluidez na composição do bando.

Lathrap (1968, 1970) como já demonstrado no capítulo 2, coincidiu em determinados aspectos com Meggers, em relação às ocupações humanas antigas na bacia da Amazônia, de que o ambienta tropical não comportaria formas de organização social que não tivessem acesso considerável à fontes de carboidratos, obtidas principalmente do consumo de bens cultiváveis. Para eles, as sociedades contemporâneas que pussuiam tais característísticas, eram resultado de um processo histórico recente de pressões populacionais e tomada de territórios, forçando comunidades tradicionais, agrárias, a se adaptarem de forma diferenciada ao meio ambiente, constituindo uma economia de caça e coleta, complementada por um sistema de trocas constantes com grupos horticultores. 
Em meados dos anos 1960, Pierre Clastres (2003) contribuiu de forma original para o debate acerca das sociedades caçadoras-coletoras em ambientes tropicais, tratando de comunidade contemporâneas. Dado o parco conhecimento de então, e a forte influência do determinismo ambiental nos estudos das sociedades não horticultoras, é surpreendente o esforço de Clastres em combinar o desenvolvimento das pesquisas etnográficas com as arqueológicas:

Em "A sociedade contra o estado", Clastres delineia um pensamento epistêmico que quebra radicalmente com a concepção etapista do desenvolvimento das instituições de poder, um pouco em comparação com o que Sahlins havia feito no campo econômico (1973). Nessa obra, ele empregou um uso afirmativo da noção de sociedade primitiva, invertendo a lógica valorativa da presencia-ausência dos componentes que qualificam as relações sociais: “Cada um de nós traz efetivamente em si, interiorizada como a fé do crente, essa certeza de que a sociedade existe para o Estado. Como conceber então a própria existência das sociedades primitivas, a não ser como espécies à margem da história universal, sobrevivências anacrônicas de uma fase distante e, em todos os lugares há muito ultrapassada?"

Clastres responde essa pergunta rejeitando o evolucionismo e o etnocentrismo, criticando a convicção complementar de que a história possui um sentido único, "de que toda a sociedade está condenada a inscrever-se nessa história e a percorrer as suas etapas”. Para ele, os homens destas sociedades indígenas garantem um domínio pleno do meio natural, pois perpetuam-se no espaço e no tempo como unidade social coesa, adaptados às suas necessidades. Logo, não pode-se falar em inferioridade técnica, estes contemplam seus desejos da mesma forma que nós, hoje em dia, satisfazemo-nos com nossos desejos industriais. Para ele, "não existe hierarquia no campo da técnica, nem tecnologia superior ou inferior", pois só se pode medir um equipamento tecnológico pela sua capacidade de satisfazer as demandas geradas pela mesma sociedade que o produz. 
E essas demandas, são regidas sob quais elementos? A grande questão, para ele, é de que essas sociedades primitivas são, em sua essência, igualitárias, “os homens são senhores de sua atividade" e donos da circulação desses produtos. Em outras palavras, o acesso aos recursos naturais se dá, nas sociedades pré-cabralinas, de forma direta e individual. O campo econômico e o campo político dessa forma de organização social não são totalmente distinguíveis, só se torna, afirma Clastres, quando a noção de trabalho surge como elemento alienante das relações de produção

Em uma sociedade organizada de forma que todos os indivíduos possuam acesso direto aos recursos, em que não há controle político das relações de trabalho, o desenvolvimento das técnicas e das ferramentas se torna uma necessidade que está nas mãos dos indivíduos enquanto coletividades. Ou seja, os fatores que explicam as mudanças nas tecnologias de produção são encontrados em stresses e justificativas que existem dentro das próprias contradições destes grupos. A atividade de produção, diz ele, "é exatamente medida, delimitada pelas necessidade que tem de ser satisfazer, estando implícito que se trata essencialmente das necessidades energéticas: a produção é projetada sobre a reconstituição do estoque de energia gasto".

Esse ponto é importante pois faz pensar acerca dos processos de mudança sócio econômicas das sociedades ameríndias. Se houve um grande turning-point nessa história de longa duração, que poderia ser o Formativo, que representou um salto produtivo, um aumento na capacidade de obtenção de recursos energéticos, aumento populacional, etc., onde esses elementos são visíveis no registro arqueológico? Em que medida o aparecimento da cerâmica ou da Terra Preta refltem, por exemplo, nesse modelo?

Clastres, de maneira original, atentou-se à sociedades indígenas contemporâneas, como os Yanomami e os Guayaki do Paraguai que, com o constante contato dos europeus e do surgimento de ferramentas e técnicas sofisticadas, como o machado de ferro, cavalos e armas de fogo; optaram estes por substituir um padrão de subsistência que antes era calcado na horticultura e no padrão de assentamento perene por um economia que se 
caracteriza-se por ser mais diversificada e ocupação do espaço mais disperso. Ou seja, pela perspectiva clássica de desenvolvimento técnico, existem casos na Amazônia de comunidades indígenas que com a entrada em eu rol material de instrumentos europeus, optaram por um modo de vida menos "sendentário".

Esse movimento é notado também em outro trabalho clássico da antropologia brasileira, com o estudo dos grupos Parakanã feito por Carlos Fausto (2001). No baixo rio Tocantins, Fausto estudou dois grupos de indígenas falantes da língua Parakanã, os Orientais e os Ocidentais, que quando contatados no início dos anos 1970, apresentaram “modos de subsistência e de organização sócio-política bastante distintos" um do outro. Um deles possuía um sistema agrícola relativamente bem diversificado e se organizavam ao redor de um chefia; já o segundo não praticavam a agricultura, “não possuíam chefes nem segmentação social”.

Através de estudos etno-histórico, Fausto demonstrou que estas duas sociedades possuíam uma raiz comum, que no final do século XIX, os blocos foram se dividindo e se diferenciando principalmente em relação à mobilidade. Essa mudança teve um impacto grande não só nos aspectos das formas de obtenção de recursos, mas também nas conformações das linhagens de parentesco, que não iremos debater, mas que para ele são muito importantes.

Para solucionar essa pergunta, de porque ocorreu tal diferenciação (que no fundo é a mesma que nos fazemos ao tratar do Formativo), Fausto levante duas hipóteses:

1. De que o padrão de subsistência dos Orientais (horticultores/sedentários) representa uma forma arcaica, enquanto a dos Ocidentais (não- horticultor) é consequência de um processo sócio-econômico posterior à separação, fazendo com que nós procuremos explicar apenas como estes perderam a agricultura; 
2. De que não há oscilação entre agricultura e forrageio desde antes da cisão, e que no século XX o que se viu foi um agravamento das diferenças, levando cada um dos grupos para um dos campos

Fausto procura problematizar a questão, buscando entender o papel dessas fontes de alimentação na lógica da obtenção de recursos das duas sociedades. Para ele, a importância da agricultura e do consumo dos bens cultiváveis é muito mais um reflexo das nossas perspectivas eurocêntricas de produção de alimentos do que de fato seria significativo para as sociedades Parakanã. O papel da caça na economia dos dois grupos, por exemplo, talvez tenha uma importância tanto na obtenção de proteínas, como para as relações que estes possuem com o meio ambiente que, diz ele, configura-se como um elemento mais definidor das relações sociais do que a agricultura em si. A perenidade das roças e a consequente estabilidade dos assentamentos se apresenta não como uma alternativa inviável à determinadas pressões que poderiam existir, pelo contrário, essa "era uma das alternativas" com que os indígenas poderiam ter escolhido, e de fato, ele conclui que estes "escolheram viver como viveram".

A conclusão de Fausto é um giro teórico pois retira a carga na inexorabilidade do movimento sócio-econômico que parece seguir um caminho único. Do seu ponto de vista, a dita regressão não deve ser encarada pelo seu víeis negativo, “como se fosse um refugo da história, evidência de um fracasso", mas sim como:

"produto de interação de múltiplas determinações que se realizam em circunstâncias e contextos históricos particulares através da ação de agentes sociais. Isso implica, por um lado, não tomála simplesmente como resultado de uma força exógena-política ou ecológica-que determina uma estratégia de sobrevivência, mas como produto da interação dessas forças com processos intestinos e mecanismo de tomada de decisão"

A relação dos Parakanã com a forma de obtenção de recurso talvez seja, nesse sentindo, um dos elementos menos importantes na sua forma de interação social, sendo o resultado, ou seja, a configuração da sociedade que vemos atualmente (na época do 
contato, em 1970) é reflexo de uma variedade de possibilidades de escolhas, sendo que esta corresponde (a atual) é a que melhor responde aos problemas criados pela própria comunidade. Nesse sentido, Fausto inclui um elemento para nós que é chave para pensar nesse processo que é a ESCOLHA DO AGENTE SOCIAL.

A carga de responsabilidade que se dá ao homem nos processos de transformação entre sociedade caçadoras-coletoras é um aspecto, por exemplo que não é abordado pelas correntes que teorizaram sobre do conceito do Período Formativo, mas que é a base sustentativa do que Childe define como processo revolucionário. Aos poucos, vamos compreendendo que os problemas teóricos envoltos na significação de tais conceitos correspondem à perspectivas de diferentes formas de enxergar as dinâmicas sociais das formas de organização destas comunidades pretéritas.

O exemplo dos Parakanã é interessante para pensarmos a ideia de subsistência na floresta tropical fora do padrão fartura $\mathrm{x}$ escassez. Outros casos de grupos contemporâneos que não possuem uma economia baseada primordialmente na agricultura pululam nas Américas. Guajás, Yuquis, Avá-Canoeiraos e Sirionós aparentemente também foram parte de um processo em que, por razões diversas, abandonaram a horticultura e adotaram um padrão de subsistência calcado em outras fontes de recursos naturais, sem, no entanto, sofrerem de prejuízo em relação à qualidade de obtenção de energia.

O que permite, no entanto, que esses dinâmica de obtenção de recursos seja tão fluída nas sociedade ameríndias, e em particular, nas Terras Baixas tropicais? Fausto não chega a responder com precisão essa pergunta, mas levanta considerações importantes acerca das diferenciações entre os dois grupos (caçadores-coletores/horticultoresceramistas). Para ele, a diferenciação está muito mais calcada em padrões de "regimes sociocosmológicos" distintos, um centrífugo e outro centrípeto, de maneira que "ambos se voltam para a produção social de pessoas como mecanismo de reprodução generalizado da sociedade, mas de maneiras diversas". Estes aspectos são talvez, muito subjuntivos 
quando trata-se do estudo do registro arqueológico, lembramos que Fausto está a estudar sociedades contemporâneas a ele, e seu levantamento histórico, exaustivo, no entanto não excede os 200 anos pretéritos. No entanto, as colocações que o antropólogo faz em relação aos processos de mudança sócio-econômico nas sociedades ameríndias é uma grande contribuição ao entendimento dessa dicotomia na pré-história.

Voltando ao questionamento, em consonância com a posição "antropogênica" de Fausto, o mesmo Clastres tenta resolvê-la através de uma abordagem um pouco distinta. Pensando na concepção marxista de trabalho, ele crê que nas sociedades primitivas as formas de produção destes indivíduos estão calcadas justamente nas uniformidades do acesso aos recursos, e no manejo do excedente, que se dá justificando, de forma dialética, a pluralidade do domínio sobre a produção. Quer dizer, nas sociedades ameríndias, os indígenas produzem para viver, seu excedente corresponde ao cumprimento das práticas sociais ligadas à troca, estabelecendo vínculos entre os parentescos que reforçam, mais uma vez, a não diferenciação política, o não-classismo. São sociedades, para ele, "sem economia por recusarem a economia", pensando esta como um espectro de uma sociedade estratificada e desigual.

O que permite portanto, que alguns grupos indígenas variem de organizações caçadoras-coletoras para ceramistas-sedentárias é que, em todos os casos, estas mudanças não afetam a profundidade das relações sociais expressas nas formas de acesso aos recursos. Grupos caçadores-coletores, diz ele, "nômades ou não, apresentam as mesmas propriedades sócio-políticas que seus vizinhos agricultores sedentários: infraaestruturas diferentes, superestruturas idênticas". De nada adianta, em resumo, as inovações técnicas, o aumento populacional ou o sistema de assentamento se as relações de produção permanecem as mesmas.

E nesse sentido, ele conclui com talvez a mais emblemática de suas assertivas acerca destes processos de transformação sócio-econômicos 
"É então a ruptura política - e não a mudança econômica - que é decisiva. A verdadeira revolução, na proto-história da humanidade não é a do neolítico, uma vez que ela pode muito bem deixar intacta a antiga organização social, mas a revolução política, é essa aparição misteriosa, irreversível, mortal para as sociedades primitivas, o que conhecemos sob o nome de Estado” pp215

Para ele, a estrutura produtiva dos indígenas da Floresta Tropical - as sociedade primitivas- é diametralmente oposta à conformação de uma estrutura estatal. Clastres tem razão, é no controle das forças produtivas e nas mudanças profundas das relações de trabalho que é possível que haja uma radical transformação nas práticas sociais destas comunidades, como aconteceu nos Andes e na Mesoamérica. No entanto, não há dissonância entre a superestrutura e a infraestrutura, como ele diz, elas andam juntas, os aspectos econômicos e políticos destas sociedades funcionam através do complexo sistema dialético explicado no capitulo 2. A esse complexo, propomos que se utilize o conceito de Modo de Produção de Parentesco.

A base para essa concepção vem de Wolf, de seu livro Europe and the People Without History (1982), uma crítica da periodização da história das sociedades humanas, calcado muito na teoria de sistema-mundo. O norte-americano estabelece o Modo de Produção de Parentesco como ferramenta explicativa da forma de interação social das sociedade ameríndias, uma das formas de organização plural com que os seres humanos viveram. Uma explicação mais aprofundada do conceito de Modo de Produção encontrase no capitulo 2, iremos aqui explicar, o que se configura então, um Modo de Produção de Parentesco (MPP), e porque é uma ferramenta útil para análise do desenvolvimento das sociedades indígenas nas Terras Baixas.

O Modo de Produção de parentesco, segundo Wolf (1982) é um mecanismo que canaliza o trabalho social para a transformação da natureza por meio das relações de filiação e casamento, consanguinidade e afinidades. Por meio do parentesco, diz ele, " $o$ trabalho social se encerra nas relações particulares da gente". Está calcado na 
perspectiva primordial de relações sociais recíprocas, de forma que cada um dos indivíduos possua acesso direto aos recursos, sendo possuidores de suas forças de trabalho, que são gerenciados, em uma maneira mais geral, pelas relações de parentesco e filiação. O controle do trabalho, nesse sistema, está diretamente nas mãos das pessoas, o trabalho não é alienado, diferentemente no capitalismo, onde opera um controle dos meios de produção sob uma só classe, no MPP, o trabalho, como elemento substantivo das relações sociais, não aparece intermediado por outros agentes sociais, a não ser o próprio trabalhador.

A lógica do MPP é que a reprodução da vida é a precondição para sua reprodução, enquanto sistema. É o controle do trabalho social sobre a subsistência que garante a existência de mecanismo homeostático da produção, é o que garante o não acesso restrito, por exemplo do excedente, e o que implica na não existência de classes sociais.

Toda sociedade produz excedente, a sua finalidade e sua posse são um dos elementos centrais para a compreensão do modo de produção característico. No MPP, a apropriação do trabalho excedente, que é o que gera a mercadoria excedente, é coletiva, se dá através "de grupos cooperativos temporários ou semipermanentes, ou através de unidades ideológicas dento das quais o grupo é dividido" (Hindess\&Hisrt,, 1975), principalmente, no caso, as unidade familiares, calcadas nas relações de parentesco.

Hindess \& Hirst afirmam que a apropriação do excedente nesse tipo de modo de produção se dá através da intervenção de determinadas relações sociais entre os indivíduos que são exemplificadas no sistema de redistribuição dos produtos. O mecanismo que rege a redistribuição do que é produzido é ideológico, não é econômico como a compra da força de trabalho, o excedente sendo redistribuído garantindo a afirmação de laços de parentesco ou de afinidade reafirma o caráter coletivo da apropriação, sem intermediários. 
As variações, dentro desse sistema, se dão na intensidade da redistribuição dos produtos, que pode ser dar através das relações precisas entre os indivíduos, de forma simples (1), ou baseada em uma complexa rede de relações sociais (2), sendo redistribuída (a produção) de acordo com as necessidades dos corpos sociais distintos. Ou seja, é claro que há diferenças entre as diversas formas e organização social dentro do MPP, suas especificidades aqui são caracterizadas por variáveis que são comparativas. O regime de propriedade e a funcionalidade do excedente são exemplos de elementos que podem ser comparados entre sociedades ao longos dos tempos.

O caso de sociedades agrícolas do segundo tipo, definido por Hindess \& Hirst, é muito semelhante ao que Maillassoux (1972) define, em que há um aumento da intensidade de cooperação entre os grupos e equipes de trabalho, extensão das relações de parentesco, aumento do sistema de trocas, mas, no entanto, permanece consistente a forma de apropriação coletiva do trabalho. Há momentos, portanto, em que as dinâmicas destas sociedades ameríndia "esfriam” e "esquentam" (Neves, 2013), aumentam-se as redes e troca, amenta-se a necessidade de produção de excedente (objetos de prestígio sem valor de troca). $\mathrm{O}$ excedente, nesse caso, aparece justamente como justificativa para a consolidação destas ligações de parentesco (Godelier, 1972).

Barbara Bender $(1978,1995)$ fez uma abordagem muito semelhante ao do MPP, utilizando-se do conceito de produção doméstico, de Marshall Sahlins (1972). Sua proposta é que a definição que Sahlins oferece ao contexto de camponeses agricultores é igualmente aplicável à grupos caçadores-coletores. Para eles, a unidade básica de produção da economia doméstica é justamente a casa, não em um sentido eurocentrista, mas pensando em todas as relações que uma família possui entre si e entre suas redes familiares, são os princípios das linhagens que organizam a produção: "Essentially ir produces for use; either direct use or for use in reciprocal exchanges os essential commodities. Its objective is to reproduce itself, not to accumulate wealth". 
Para Wolf, Sahlins e Bender, é na distribuição da produção que se encontra a qualificação deste modo de produção. Para eles, todas as relações sociais requerem a produção de um excedente (surplus), excedente este que se configura, por exemplo, em materiais ligados à cerimônias de casamento ou legitimação de relações de prestígio. E o caminho que o excedente cumpre na sociedade é um exemplo importante para pensar acesso aos recursos, regimes de propriedade e relações de trabalho.

A produção, neste sistema, serve como mecanismo que sustenta o padrão das relações sociais, que é dado pela igualdade de acesso aos recursos, e respaldado nos sistemas de aliança de parentesco, diferente do capitalismo, por exemplo, onde a produção tem como função a opressão de determinada classe social. A reciprocidade do excedente produtivo é o conceito chave que explica essas relações entre unidades produtivas, pois as alianças envolvem obrigações de dar, receber e retribuir, a demanda da unidade doméstica individual é dada justamente pelas relações de troca que se dão entre os grupos de linhagem.

Bandos caçadores-coletores, diz Bender (1995), também estão imbuídos desse sistema, pois produzem produtos através de trabalho (labour), e trabalho sempre é um elemento social, coletivo, logo, unidades produtivas de grupos caçadores-coletores nunca são autônomas, dependem dos recursos produzidos por outras unidades produtivas, por outras famílias. Há, diz ela "a necessidade destes grupos se moverem através da paisagem, para terem acesso à diferentes recursos e serem demograficamente flexíveis, é essencial que possuam relações sociais recíprocas".

Nesse sentido, fica claro que, dada a mudança na base alimentar, na prática da obtenção de recursos, ou qualquer outro elemento comumente relacionado ao processo do Período Formativo, estas mudanças não estão calcadas em profundas modificações das relações sociais, pois estas estão fortemente imbricadas nos modelos de apropriação dos recursos, da relação entre as forças produtivas e a manutenção da mesma pelas homens. A grande mudança, nessa perspectiva, como afirma Clastres, não é com o aparecimento 
da cerâmica ou com o advento da agricultura, pois os homens continuam a se relacionar, em grande medida, da mesma forma que antes. Os elementos que caracterizam as relações sociais de sociedades caçadoras-coletoras e de sociedades ceramistas-sedentárias parecem continuar sendo os mesmo, até o momento em que ocorre uma divisão inicial classista, que para ele é representado pelo surgimento do Estado.

Childe de certa foram antecipou essa discussão, ao configurar esse período como o resultado de dois processos que são distintos, a Revolução Neolítica e a Revolução Urbana. Na lógica do materialismo-dialético proposto, a Revolução Neolítica, não pode ser encarada como uma mudança profunda das relações sociais, pois os meios de produção continuam sendo controlados individualmente pelas unidades produtivas, comunalmente se apropriando do seu excedente. A revolução Urbana, por outro lado, é reflexo claro da acumulação primitiva de capital, é a materialização da transformação na mercadoria do seu valor de uso por seu valor de troca, é início do comércio, da exploração da mão-de-obra, etc.

A apropriação do conceito de Modo de Produção de Parentesco nos permite, assim como Bender o fez, analisar a história do desenvolvimento das sociedades humanas de maneira distinta, porém, racional e ontológica. Os problemas classificatórios apresentados no segundo capítulo acerca das inúmeras definições do Período Formativo na América tornam-se fluídas se pensarmos que, independente das inovações tecnológicas ou mudanças no campo ideológico dessas sociedades, os mecanismo produtivos permaneceram os mesmo, as bases das relações sociais não foram modificadas, a noção de trabalho para estas pessoas não sofreu mudança.

No Floresta Tropical, portanto, é o que explica a fluidez dos Parakanã e dos Nhambiquara, é o que permite que os Aché, no Paraguai, mantenham uma economia de subsistência hora baseada na agricultura semi-intensiva, hora baseada na caça itinerante. A grande questão nesta proposta (de utilização do conceito de MPP) é que a redistribuição dos recursos obtidos através do trabalho (labour) não se modifica com o advento da 
cerâmica, pois o papel social dos integrantes desse sistema (seja caçador-coletor ou agricultor) permanece o mesmo.

E o caso do sítio Teotônio é emblemático nesse sentido, pois possui aportes que a literatura definiu como sendo clássicos de sociedades caçadoras-coletoras (a não presença de material cerâmico) concomitantemente, na mesma camada arqueológica, com o grande indício da modificação antrópica do meio ambiente, que é a Terra Preta. A conjunção dos dois fatores confunde, de certa forma, a perspectiva clássica de "check-list" que consagrou-se na definição dos períodos pré-colombianos na América. É preciso entender que, assim como em complexos contextos como Huaca Prieta ou Penã Roja (ArroyoKalim, 2010), o modo de subsistência que reflete a junção de elementos que são tradicionalmente vistos como distintos, é na verdade a concretude material apenas de uma das inúmeras possibilidades comportadas dentro deste modo de produção.

O Modo de Produção de Parentesco não define, por si só, todos os elementos da história desses povos, o materialismo-dialético como instrumento de reconstrução histórica serve para estabelecer parâmetros que indiquem até que ponto as relações sociais, nessas conformação das forças produtivas, podem ir. Assim, sabemos que as sociedades indígenas das Terras Baixas sul-americanas não desenvolveram estruturas estatais pois seus aspectos relacionado aos meio de produção não permitem, dada à lógica redistributiva dos bem produzidos. Agora, no Modo de Produção de Parentesco, é plenamente plausível que haja uma sociedade que não produz cerâmica, que maneja com qualidade os recursos botânicos, produzindo Terra Preta, e que mantenha uma relação estável e duradoura com o meio ambiente. O Modo de Produção de Parentesco é a definição que surge a fim de eliminar os problemas metodológicos que a literatura tradicionalmente tem com a definição do Formativo, pois não o entende como um processo que levou a algo, mas sim uma das formas de constituição do modo de vida destas sociedades que possuem uma maneira singular, e ao mesmo tempo coesa, de se apropriarem do meio. 
O contexto arqueológico no alto Rio Madeira parece questionar as definições do uso do Formativo como unidade classificatória não porque é uma exceção, mas sim porque o conceito é deficitário, ele não compreende a totalidade das diferentes maneiras das corpos sociais se relacionarem. Encontrar elementos que tradicionalmente são relacionados à sociedades caçadoras-coletoras junto com "fósseis-guias" de economias horticultoras-sedentárias é a comprovação material de que os mesmo não podem ser entendidos como bons marcadores da classificação dos processos históricos das sociedades humanas.

O intento aqui é, ao rejeitar o evolucionismo-cultural inerente ao emprego das definições clássicas do Formativo, compreender que existem outras formas de explicação destes processos históricos que justificam as variadas maneiras de organização social.

A inserção do conceito de Modo de Produção de Parentesco nos contextos arqueológicos das Terras Baixas Sul-americanas é uma proposta que insere-se nos questionamentos contemporâneos em contrapartida às explicações tradicionais, mas que procura ser ao mesmo tempo propositivo, através da objetivação dos elementos históricos. Como cita Neves (1995), "pelo fato de ligar a organização social à organização de produção, pode se tornar (o modo de produção de parentesco) uma maneira de evitar o pensamento determinista monocausal". Refutar o período Formativo como elemento classificatório só faz sentido se explicarmos, de outra maneira, de que forma estas relações sociais se deram, ou de que maneira os tradicionais elementos deixaram de ter importância, e nesse sentido a proposição se apresenta como um sintetizador de uma história de longa duração na floresta tropical.

Quando Neves (2012) que se pergunta “por que, após dezenas de milhares de anos vivendo como caçadores-coletores, as sociedades humanas abriram mão de sua liberdade em prol da agricultura e do estado?", buscamos respondê-lo a partir da especificidade das sociedades amazônicas, que não escolheram esse caminho. Por terem desenvolvido uma maneira distinta de se relacionar com o meio que não envolve os conceitos evolucionistas, ou nos prendemos às especificidades de cada uma das diferentes 
formas sociais para explica-las, ou construímos uma narrativa histórica coerente que faça sentido às populações contemporâneas, as quais servem nossa produção acadêmica. 


\section{Bibliografia}

ALMEIDA, F. O. de

2008. A expansão Tupinanbá do sul da bacia do Amazonas. Projeto de Doutorado.

PPGA-MAE-USP. Enviado à Fundação de Amparo a Pesquisa do Estado de São

Paulo - FAPESP. 2011. As Expansões Tupinanbá noSul da Bacia do Amazonas.

Terceiro Relatório Annual FAPESP. Processo 2008/58419-9 2013. A Tradição

Polícroma no Alto Rio Madeira. Tese de Doutorado. São Paulo:MAE/USP

\section{ALTHUSSER, L.}

1967. Dialética e as Ciências Sociais. Rio de Janeiro: Zahar

\section{ANDREFSKY.W.}

2008. Lithic technology: measures of production, use, and curation. New York: Cambridge University Press

2002. Lithics: Macroscopic approaches to analysis. Cambridge: Cambridge University Press

ARROYO-KALIN, M.

2010. A Domesticação da paisagem: os solos antropogênicos e o Formativo na Amazôniain Pereira, E. \& Guapindaia, V.(orgs). Arqueologia Amazônica 1. Belém: MPEG; IPHAN; SECULT

AZEREDO, A.C.

2011 A Variabilidade da Cerâmica Arqueológica da Tradição Polícroma Amazônica: um estudo de caso entre um sítio do Alto Madeira e um sítio da Amazônia Central. Relatório(Final) FAPESP de Iniciação Científica. São Paulo, MAE-USP.

BAILEY, R.; HEAD, G.; JENIKE, M; OWEN, B.; RECHTMAN, R.; ZECHENTER, E. 1989. Hunting and Gathering in Tropical Rain Forest: IS it Possible?. American Anthropolist. New Series, Vol. 91 (Março). Pp 59-82

BALIBAR, E.

1995. A Filosofia de Marx. Rio de Janeiro: Jorge Zahar

BARRETO, C

2014. Social Complexity in Ancient Ameridian Societies: Perspectives from the Brazilian Lowlands. In Gnecco, C; Langebaek, c (ORG.) against Typological Tyranny in Archaeology. Springer Science Business Media. New York. 
BAR-YOSEF, O. 2002.

The Upper Plaeolithic Revlution. Annual Re. Antropology. Vol 31: 363-193

BATE, L. F.

1983. Hipotesis sobre la sociedade Classista in Arqueologia y Marxismo Contribuciones al Pensamiento Marxista en la reflexion arqueológica. Mexico DF: Las Armas de la Critica

BENDER, B.

1978. Gatherer-hunter to farmer: a social perspective. Wordl Arcaheology. Vol 10. $\mathrm{N}^{\mathrm{o}}$ 1. Pp204-222

2005. The roots of inequality. In Miller, D.; Rowlands, M.;Tilley, C. Domination and Resistance. London and New York: Routledge

\section{BUENO L.}

2013. The Late Pleistocene/Early Holocene archaeological record in Brazil: A geo-referenced database. Quaternary Internationa v. 301, p. 74-93

BUENO, L.; PEREIRA, E.

2007 Indústrias líticas em sítios cerâmicos na Amazônia: um estudo do sítio Domingos, Canã̃ dos Carajás, Pará. Revista do Museu de Arqueologia e Etnologia, São Paulo, 17: 99-126

\section{CHILDE, G,}

1965.Man Makes Himself. Londres: Watts

1942, The Significance of Societ Arcaheology. Labour Monthly. Novembro.pp 341-343

1944. The Story of Tools. Young Communist League Story of Science serie pamphlet.. London: Cobbet Publishing

1946. What Happened in History. New York: Penguin Books

1947. History. London: Cobbet.1965.Man Makes Himself. Londres: Watts

\section{CLASTRES, P.}

2003. A Sociedade contra o Estado: pesquisas de antropologia política. São Paulo: Cosac Naify 
COLINVAUX, P.; BUSH, M.

1991. The Rain-Forest Ecosystem as a Resource for Hunting and Gathering.

American Anthropologist, New Series, Vol 93, No 1. Pp153-160

CORTESÃO, J.

2006.Alexandre de Gusmão e o Tratado de Madrid, São Paulo: Conag

COSTA, A.

2013. Entre artefatos e Narrativas: A História indígena do Alto rio Madeira a partir dos relatos dos viajantes do século XVIII. Monografia de Conclusão de Curso. Departamento de História - UNIR

COSTA, B.

2012, Levantamento Arqueológico na Reserva de Desenvolvimento Sustentável (RDS) Amanã- Estado do Amazonas. Dissertação deMestrado. Universidade de São Paulo. São Paulo.

COSTA F.

2002.Análise das Indústrias Líticas da Área de Confluência dos rios Negro e Solimões. Tese de Doutorado, São Paulo: PPGA-MAE-USP.

DIAZ, M.; TANTALEÁN, H.

2008. El Vuelo de Hermes: Uma Crítica a La Posmodernida em Arqueología desde los Andes. Maguaré. № 22. Bogotá. Pp397-423

DOBE. M.

1946. Studies in the Development of Capitalism. New York. International Publishers

DONATTI, P.

2003. A ocupação pré-colonial da área do Lago Grande, Iranduba, AM. Dissertação de Mestrado. São Paulo: PPGA-MAE-USP

DUNNEL, R.C

1986. Five Decades of American Archaeology. In D. Meltzer et al., eds. American Archaeology Past and Future. Washington, DC: Smithsonian Institution Press, pp. 23-52.

ENGELS, F.

2012 (1884) A Origem da Familia, da Propriedade Privada e do Estado. Rio de Janeiro: Expressão Popular 
FAUSTO, C.

2001. Inimigos Fiéis: história, guerra e xamanismo na Amazônia. São Paulo: EDUSP

FAULKNER, N.

2007. Gordon Childe and Marxist archaeology. International Socialism, $\mathrm{n}^{\circ} 116$, Setembro.

FELIX, G.

2012. O Potencial da Arqueobotânica na elucidação das relações estabelecidas pelos grupos amazônicos com o mundo vegetal. Trabalho de Conclusão de Curso - Centro de Ensino Faculdade São Lucas - Porto Velho

FERREIRA, A. R.

2003. Viagem ao Brasil II; Expedição philosophica pelas Capitanias do Pará, Rio Negro, Mato Grosso e Cuyabá. Petrópolis: Kapa Editorial, 2003

FORD, J.

1969. A comparison of formative cultures in the Americas: difusion or the psychic unity of man. Washington: Smithsonian Institute.

FURQUIM, L. OLIVEIRA, E. SHOCK, M.

2013. Arqueobotânica no Alto Madeira: um estuo de caso a partir do sítio Teotônio - RO. Apresentação de Painel. XVII Congresso da Sociedade de Arqueologia Brasileira - Aracaju-SE.

GIDDENS, A.

1979. Central Problems in Social Theory: Action, Structure and Contradiction in Social Analisys..London: Mcmilliam

GILMAN, A.

1989. Marxism in American Arcaheology. In Lamberg-Karlocvsky, C. Arcaheological thought in America. Londres: Cambridge University Press.

GNECCO, C.

1999. Multivocalid histórica: hacia uma cartografia poscolonial de la arqueologia. Universidade de los Andes: Bogotá

GNECCO, C.; MORA, S.

1997. Late Pleistocenelearly Holocene tropical forest occupations at San Isidro and Peña Roja. Colombia. Antiquity 71:683-690 
GODELIER, $M$

1977. Perspectives in Formative Archaeology. Cambridge: Cambridge University Press.

GOMES, D.

2011, Cronologia e Conexões Culturais na Amazônia: as sociedades Formativas da região de Santarém, PA. Revista deAntropologia. Vpl54 $\mathrm{n}^{\circ} 1$, FFLECH. Universidade de São Paulo: 269- 314.

GOSDEN, C.

1999. Anthropology and archaeology: a changing relationship. London: Routledge

GOULDING, S.

1979. Ecologia da pesca no Rio Madeira. Manaus: Conselho Nacional de Desenvolvimento Científico e Tecnológico, Instituto Nacional de Pesquisas da Amazônia.

1997. História Natural dos rios Amazônicos. Brasília: Sociedade Civil Mamirauá

GRAMSCI. A.

2006. Cadernos do Cárcere. Rio de Janeiro: Civilização Brasileira. 91

HASTORF, Christine.

2006. Domesticared Fodd and Society in Early Coastal Peru in Balée, W. \& Erickson C. Time and Complexity in Historical Ecology. New York Columbia University Press

HEADLAND, T.; BAILEY. R.

1991. Have Hunter-Gatherers ever lived in Tropical Rain Forest Independently of Agriculture? Human Ecology, v19, nº 2

HECKENBERGER , M

2002, Rethinking the Arawakan Diaspora: Hierarchy, Regionality, and Amazonian Formative. Hill, J., Santos-Granero, F. (Eds.). Comparative Arawakan Histories: Rethinking Languag, Familyand Culture Area in Amazonia. Urbana/Chicago. Universidade de Illinois: 99-122

HERDORN, W. \& GIBBON . L.

2000. Exploration on the Valley of the Amazon [1854], New York: Grove Press.

HEIDEGGER, M.

1972. 'Time and being', On Time and Being, Harper and 
HILBERT P.P., HILBERT, K.

1980, Resultados Preliminares da Pesquisa Arqueológica nos rios Nhamundá e Trombetas, baixo Amazonas. Boletim do Museu Paraense Emilio Goeldi. Antropologia $n^{\circ} 75:$ 1-15.

HINDESS, B. ; HIRST, P.

1975. Pre-capitalist modes of production. London: Routledge \& Kegan Paul

HOBSBAWN. E.

2012. Como Mudar o Mundo: Marx e o Marxismo. São Paulo: Companhia das Letras

HODDER, I.

2006. Theory and Practice in Archaeology. London: Routledge.

INGOLD, $\mathrm{T}$.

2000.The optimal forager and economic man IN Ingold, T. The Perception of the environment: essays on livelihood, dwelling and skill. London and New York: Routledge

KATER, T

2014. Curadoria e Análise do material cerâmico do sítio Teotônio. Relatório parcial de Iniciação Científica. CNPq.

KELLER, F.

1874.The Amazon and Madeira Rivers. New York: D. Aplleton \& Co. 1874

\section{KIDDER, A.}

1926 An Introduction to the Study of the Southwestern Archaeology. Papers of the Southwestern Expedition No. 1, New Haven, 1924

KOHL. P.

1981. Materialist Approaches to Prehistory. Annual Review of Anthropology 10: 98-118

KORSCH, K.

2008. Marxismo e Filosofia. Rio de Janeiro: UFRJ

KROEBER, A..

1925. Handbook of South American Indians. Washington, Govt. print.

1930. Cultural relations between North and South America. Proceedings of the $23^{\text {rd }}$ International Congress of Americanists, New York, 1928, pp. 5-22. New York. 
LAMBERG-KARLOVSKY. C.C.

2009. Vere Gordon Childe and de Concept of Revolution In SHEA, J \& LIEBERMAN D. Transitions in prehistory: essay in honor of Ofer Bar-Yousef. Oxford. Oxbow Books.

\section{LATHRAP, D.}

1968. The Hunting Economics of the Tropical Forest of South America: an attempt at historical perspective. In: Man the Hunter. Chicago: Aldine. P23-29

1970. The Upper Amazon. London: Thames and Hudson

\section{LEE, B.}

1992. Art, Science, or Politics? The crisis in Hunter-Gatherer Studies. American Anthropologist, New Series, Vol 94, No 1. Pp. 31-54

\section{LE GOFF, J.}

2008. Uma Longa Idade Média. Rio de Janeiro: Civilização Brasileira, 2008

\section{LEE, R; DE VORE, I}

1968. Foragers and Others, In The Cambridge Encyclopedia of Hunters and Gatherers. Cambridge: Cambridge University Press.

LIMA. H.

2008. História das Caretas: a tradição Borda Incisa na Amazônia Central. Tese de Doutorado, São Paulo: PPGA-MAE-USP

LOWIE, R.

1937. The History of Ehnological Theory. New York: Holt, Rinehart and Winston

\section{LOWY, M.}

2007. As Aventuras de Karl Marx contra o Barão de Munchhausen:Marxismo e positivismo na sociologia do conhecimento. São Paulo: Cortez Ed.

\section{LÚKÁCS, G.}

2003. História e Consciência de Classe: estudos sobre a dialética marxista. São Paulo: Martins Fontes.

\section{LULL, V; MICÓ, R.}

1997. Teoría arqueológica I. Los enfoques tradicionales: las arqueologias evolicionistas e histórico-culturales. Revista d'Arqueologia de Ponent 7: 107-128

\section{LUMBRERAS, L, G.}

1981. La Arqueologia como Ciencia Social. Lima: PEISA

2006. Um Formativo sin cerâmica y cerâmica preformativa. Lima: Estudios Atacameños - Arqueologia y Antropologia Surandinas, 32: 11-34 
LYMAN, R.L.; O’BRIED, M. \& DUNNEL, R.

1997. The Rise and Fall of Culture History. New York/Londos: Plenum Press

MAGALHAES. B.de 92

1939. O Café na História, no Folclore e nas Belas Artes. São Paulo: Brasiliana. V.174

MARCOS, J.

2003. A Reassessment of the Ecuadorian Formative In Raymond, J. \& Burger, L. Archaeology of Formative Ecuador: Washington D.C.: Dumbarton Oaks

MARX, Karl.

1964. Formações Econômicas Pré-Capitalistas. São Paulo: Ed Paz e Terra

1977. A Origem do Capital: A Acumulação Primitiva. São Paulo: Ed Global 2008.

O 18 de Brumário de Luis Bonaparte. São Paulo: Centauro

1977.A Origem do Capital: A Acumulação Primitiva. São Paulo: Ed Global

1970. A Contribution to the Critique of Political Economy. Progress Publishers, Moscow

MARX, K \& ENGELS, F.

1970. The German Ideology. International Publishers: New York

MCGUIRE, R.

1992. An Marxist Archaeology. London: Academic Press Limited

2006. Marx, Childe and Trigger. In Williamson, R. The Wors of Bruce Trigger: Considering aspects of his influcences. Montreal: McGill University Press. 61-79 2015. Reading and Misreading V. Gordon Childe in North America. Cota Zero: Revista D'arqueologia I Ciència 22:32-43.

MCKERN, W.C.

1945. Preliminary report on the upper Mississippi phase in Winsconsin. Milwaukee: Milwaukee Public Museum.

MEGGERS, B

1992. El contexto Ecológico del formativo in Ledengerber, P. Formativo Sudamericano: uma Revaluación. Quito: Cuenca Ed. 1954 Environmental Limitation on the Development of Culture.American Anthropologist, 56: 801823.1971 Amazonia: Man and Culture in a Counterfeit Paradise.Chicago: Aldine. MEGGERS, B.J. \& MILLER, E.Th.

Hunter-gatherers in Amazonia during the Pleistocene-Holocene transition. In: Mercader, J. (ed.) Under the canopy: Row, New York. 
MEGGERS, B; EVANS, C.; ESTRADA. E.

1965. Early Formative Period of Coastal Ecuador: The Valdivia and Machalilla

Phases. Washington: Smithsonian Institute;

MEILLASSOUX, C.

1972 From reproduction to production. Economy and Society, 1: 93-105.

MILHEIRA, R. G.

2011. Os Guarani e seus artefatos líticos: um estudo tecnológico no sul do Brasil.

São Paulo: Revista do Museu de Arqueologia e Etnologia, 2011. ; ISSN/ISBN: 01039709.

\section{MILLER, E.T.}

1978. Projeto de Avaliação do Potencial Arqueológico na Área de influência da Rodovia BR-429/ Presidente Médici-Costa Marques. Governo do Estado de Rondônia, Secretaria de Estado do Planejamento e Coordenação/SEPLAN 1978 Relatório das Pesquisas Arqueológicas no Território Federal de Rondônia (Alto RioMadeira, do Yata ao Cuniã). Resultados Preliminares. Programa Nacional Pesquisas Arqueológicas na Bacia Amazônica-PRONAPABA. 1987 Relatório das Pesquisas Arqueológicas Efetuadas na Área de Abrangência da Usina Hidrelétrica de Ji-Paraná (1986/1987). Porto Velho, RO

1992. Adaptação agrícola Pré-Historica no Alto Rio Madeira. In Prehistoria Sudamericana: nuevas perspectivas. Meggers, B.J. (Ed). Taraxacum-Washington 1992. Arqueologia nos Empreendimentos Hidrelétricos da Eletronorte. BrasíliaDF: Eletronorte

1999. A Limitação Ambiental como Barreira à Transposição do Período Formativo no Brasil. Tecnologia, Produção de Alimentos e Formação de Aldeias no Sudeste da Amazônia. InFormativo Sudamericano, una revelacions. Lederbergerber-Crespo, P. (Ed.), EdicionesAbya-Yala, Quito-Equador.

MOORE, C.R.; THOMPSON, V.D.

2012 Animism and Green River Persistent Places: a dwelling perspective of the Shell Mound. Archaic. Journal of Social Archaeology, 12(2): 264-284. 
MORAES. C. deP.

2007. Levantamento arqueológico das áreas do entorno do Lago do Limão, município de Iranduba - AM. Dissertação de Mestrado. São Paulo: PPGA-MAEUSP

2014. Arqueologia Regional na Amazônia Central: A fase Paredão e sua inserção no contexto pré-colonial Amazônico. Tese de Doutorado. São Paulo; PPGAMAE-USP

NAVARRO, E.

2013. Dicionário de Tupi Antigo. São Paulo: Global 93

MORGAN, L.

(1985 1877) Ancient Society. Arizona: University of Arizona Press.

MYERS, T. P.

1973. Towards the reconstruction of prehistoric community patterns in the Amazon basin. In: LATHRAP, D. W.; DOUGLAS, J. (Eds.). Variation in anthropology: essays in honor of John C. McGregor. Urbana: Illinois Archaeological Survey, 1973, p. 233-259.

NEVES, E. G.

1995. Villiage fissioning in Amazonia: a critique of monocausal determinism.

Revista do Museu de Arquelogia e Etnologia, v. 5, p. 192-209

1998. Changing Perspecives in Amazonian Archaeology. In Politis, G.; Alberi B. (org.). Archaeology in Latin America. Londres: Routledge, 1999. P216-243

2007. El Formativo que nunca terminó: La larga historia de estabilidad em lãs ocupaciones humanas de la Amazonía Central. Boletín de Arqueologia PUCP, $\mathrm{n}^{\mathrm{o}} 11$

2012. A Incipiência Permanente: A Amazônia sob a insistente sina da Incompletude. Conferência proferia no Seminário Antropologia e Arqueologia da Amazônia. Belo Horizonte. UFMG. Abril

2013. Sob os Tempos do Equinócio: Oito Mil anos de história na Amazônia Central (6500 ac-1500 dc). Tese apresentada para o Concurso de Título de LivreDocente. MAE/USP

NEVES, E. G., PETERSEN, J.; BARTONE, R. and SILVA, C. Augusto.

2003. Historical and socio-cultural origins of Amazonian Dark Earths. . In J. Lehmann, D. Kern, B. Glaser \& W. I. Woods, eds., Amazonian dark earths: Origins, properties, management, Dordrecht: Kluwer Academic Publishers,pp. 29-50. 
NEVES, E.; GUAPINDAIA, V.; LIMA, H.; COSTA, B.; GOMES, J.

2014. A tradição Pocó-Açutuba e os primeiros sinais visíveis de modificações de paisagem na calha do Amazonas. In Roustein, S. Amazonía: Memorias de las Conferencias Magistrales Del 3er Encouentro Internacional de Arqueología Amazónica. Quito: Ekseptiom Publicidad

\section{NOLETO, C.}

20123.Colocando as pedras no caminho: Análise tecnológica da indústria lítica do Sítio do Brejo. Trabalho de Conclusão de Curso apresentado ao Departamento de Arqueologia - UNIR/RO

\section{NOVACK, G.}

1969. An Introduction to the Logic of Marxism. New York: Merit Publishers

\section{NUNES, L. C.}

2008. Terminologia Lítica - tecnologia para o estudo da pedra lascada. Dissertação de Mestrado. Goiania: IGPA- UCG.

OLIVEIRA, W. C.

2007. Caçadores-coletores na Amazônia. Eles existem. Dissertação de Mestrado, PPGArq-MAE/USP.

OLIVER, J.

2001. The Archaeology of Forest Foraging and Agricultural Production in Amazonia in McEwan, C.,Barreto, C., Neves, E. London: The British Museum Press

PEARSALL, D.M.

1998. Domestication and Agriculture in the New World Tropics in Price. T.D., Brigitte, A. Las Hunters - First Farmers. Santa Fé: School of American Research Press

PESSOA, C.

2015. Os contextos arqueológicos e a variabilidade artefatual da ocupação Jatuarana no alto rio Madeira. Dissertação de Mestrado. PPGA/UFPA. Belém

\section{PATTERSON, T.}

2005. Craft specialization, the reorganization of production relations and state formations. Journal of Social Archaeology. Vol 5 (3): 307-337

PEACE, W.J.

1989. Vere Gordon Childe and American Anthropology. Journal of Anthropological Research, Vol 44. 417-33 
PEARSALL, D.M.

1998. Domestication and Agriculture in the New World Tropics in Price. T.D.,

Brigitte, A. Las Hunters - First Farmers. Santa Fé: School of American Research Press

PERRY. L

2002. Starch analyses reveal multiple functions of quartz "manioc" grater flakes from the Orinoco basin, Venezuela. Interciencia. Vol 27. № 11. pp635- 639

POLANYI, K.

2013. A Grande Transformação: as origens da nossa época. Rio de Janeiro: Elsevier

PROUDHON, P.

2003. Sistema das Contradições Econômicas, ou Filosofia da Miséria - Tomo I;São Paulo: Ícone

PROUS, A.

1990. Os Artefatos Líticos - Elementos descritivos classificatórios. Arquivo do Museu de História Natural. V.11, ufmg: Belo Horizonte.

REDFIELD,R.

1953 The Primitive World and Its Transformations. Ithaca, N.Y.: Cornell University Press.

RENFREW, C.; BAHN, P.

2008. Archaeology: theories, methods and practice. London: Thames and Hudson,

RINDOS. D.

1984. The origins of agriculture: an evolutionary perspective. Orlando. Academic Press

ROOSEVELT, A.

1980. Parmana: prehistoric maize and manioc subsistence along the Amazon and Orinoco. New York: Academic Press, 1980

ROOSEVELT, A.; COSTA, M; MACHADO, C.; MICHAB, M.; MERCIER, N; VALLADAS, H.; FEATHERS, J.; BARNETT, W.; SILVEIRA, M.; HENDERSON, A.; SILVA, J.; CHERNOFF, B.; REESE, D.; HOLMAN, J.; TOTH, N.; SHICK, K.

1996. Paleoindian Cave Dwellers in the Amazon: The Peopling of the Americas. Science 272 (5260): 373-384 
ROWLANDS, $\mathrm{M}$.

1984. Objective and Subjective in Archaeology.in Spriggs, M. Marxist Perspectives in Arcaheology. Cambridge: Cambridge University Press

SAHLINS, M.

1972 Stone Age Economics, Chicago: Aldine.

SCATAMACCHIA, M.C.M.

1994. Aplicação do conceito de Formativo no leste da América do Sul. São Paulo - SP. Revista de Arqueologia, 8(2):141-148

SCHIFFER, M.B.

1972. Archaeological context and systemic context. American Antiquity 156-65

SERVICE, E.

1971. Primitive Social Organization: an evolutionary perspective. New York: Random House

SHANKS M.; TILLEY.

1988. Social Theory in Archaeology. Albuquerque: University PF New Mexico Press

1987 Re-Constructing Archaeology: Theory and Practice, Cambridge University Press, Cambridge.

SHARP. L.

1952 Steel Axes for stone-age Australians. Uhuman Organization, vol 11. No2. Pp17-22

SIMÕES. M.

1983. Pesquisa e cadastro de Sítios Arqueológicos na Amazônia Legal Brasileira: 1978-1982. Belém, Rev. Museu Paraense Emilio Goeldi. Publicação Avulsa no 38

\section{SMITH.M}

2009. Gordon Childe and the Urban Revolution: An Historical Perspective on a Revolution in Urban Studies. Town Planning Review 80: 2-29

SOARES, Ana P.

2012. A.Geohistória do Rio Madeira: quando navega-lo foi preciso. Paper apresentado no I Simpósio Nacional de Geografia Histórica. Rio de Janeiro, Novembro de 2012 
SPRIGGS, M.

1984. Another way on Telling: Marxist Perspectives in Archaeology. In Spriggs, M. Marxist Perspective in Archaeology. Cambridge: Cambridge University Press. Pp1-9

\section{STALIN, J.}

1938. Dialectical and Historical Materialism. New York: International Publishers

STEWARD, J.

1948 Culture Areas of the Tropical Forests. In: Handbook of South American Indians, vol. 3, J. Steward, ed. Washington,DC: Bureau of American Ethnology, Smithsonian Institution,Bulletin 143, pp 883903.

1948 A Functional-Developmental Classification of American High Cultures in A Reappraisal of Peruvian Archaeology, ed. Wendell C. Bennett, pp. 103-4. (Society for American Archaeology Memoir No. 4.) Menasha,.

1949. Cultural Causality and Law: A Trial Formulation of the Development of Early Civilizations. American Anthropologist. New Series, Vol 51, No 1. Pp1-27 1955. Las Civilizaciones antiguas del Viejo Mundo y de América: symposium sobre las civilizaciones de regadio. Washington: Unión Panamericana

SOUZA, K.

2013. Até onde vão as cicatrizes deixadas pelo tempo? Análise lítica da ocupação humana do Holoceno Médio e Tardio na bacia do Amapari/AP, Amazônia. Dissertação de Mestrado- PPGA/UFPA. Belém.

LEVY- STRAUSS, C.

2008. Antropologia Estrutural. São Paulo: Cosac Naify

SWITKES, G.(org.)

2008. Águas Turvas: Alertas sobre as conseqüências de barrar o maior afluente do Amazonas. São Paulo: International Rivers

TAMANAHA, E.K.

2012. Ocupação Polícroma no Baixo e Médio rio Solimões. Dissertação de Mestrado: São Paulo. PPGA-MAE-USP.

TEIXEIRA, M. A. D ; FONSECA, D. R.

2006. História Regional (Rondônia). São Paulo: Instituto Vivo.

TEIXEIRA, W., KERN, D.; MADARI, B.; LIMA, H., WOODS, W.

2009. As Terras Pretas de índio na Amazônia: sua caracterização e uso deste conhecimento na criação de novas áreas. Manaus: Embrapa Amazônia Ocidental 
TRIGGER, B.

2004. História do Pensamento Arqueológico. São Paulo: Odysseus.

VIVEIROS DE CASTRO, E.

1996. Images of nature and society in Amazonian Ethnology. Annual Review of Antrhopology $\mathrm{n}^{\circ} 25$

WEBER, M.

2008. Ensaio sobre a teoria das Ciências Sociais. São Paulo: Centauro.

WILLEY, G. \& PHILLIPS, Phillip.

1967. Method and Theory in American Archaeology. Chicago: University Chicago Press.

WITTFOGEL, A.

1957. Oriental Despotism: A comparative study of total power. New Haven: Yale University Press.

WOLF. E.

1982. Europe and the People without History. Los Angeles: University of California Press.

ZIMPEL NETO, C.A.

2009. Na direção das periferias extremas da Amazônia: Estudo da Arqueologia na Bacia do Rio Jiparaná, Rondônia. Dissertação de Mestrado, MAE-USP

ZUSE, S.

2014. Variabilidade cerâmica e diversidade cultural no Alto rio Madeira, Rondônia. Tese de Doutorado. PPGAarq/MAE-USP. São Paulo 


\section{$\underline{\text { Anexos }}$}

Anexo 1- Croqui dos sítios arqueológicos com ocupações préceramistas publicados por Miller (1987, 1992). Em Vermelho, o Sítio Periquitos, do Complexo homônimo, em Laranja, os sítios com ocupação relacionada ao Complexo Girau; Em Amarelo os sítios da fase Pacatuba, em Verde os da fase Itapipoca, e em Azul, os sítios com a presença da Fase Massangana

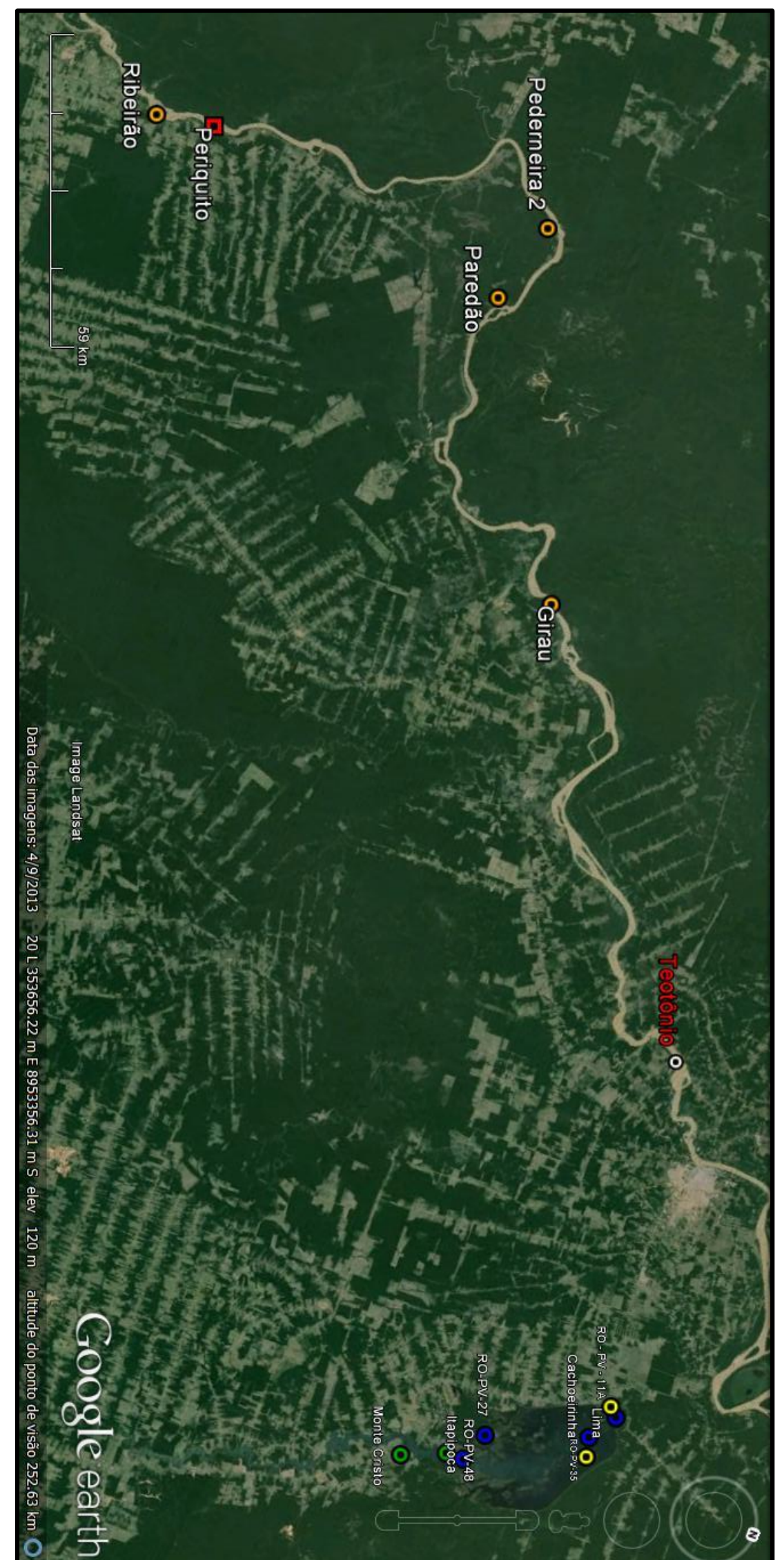


Anexo 2 - Detalhe do mapa anterios, da área do reservatório da UHE Samuel, com os sítios com ocupações pré-ceramistas levantados por Miller (1987, 1999). Em Azul, sítios da fase Massangana, em Verde os da fase Itapipoca e em Amarelo os sítios com ocupação Pacatuba.

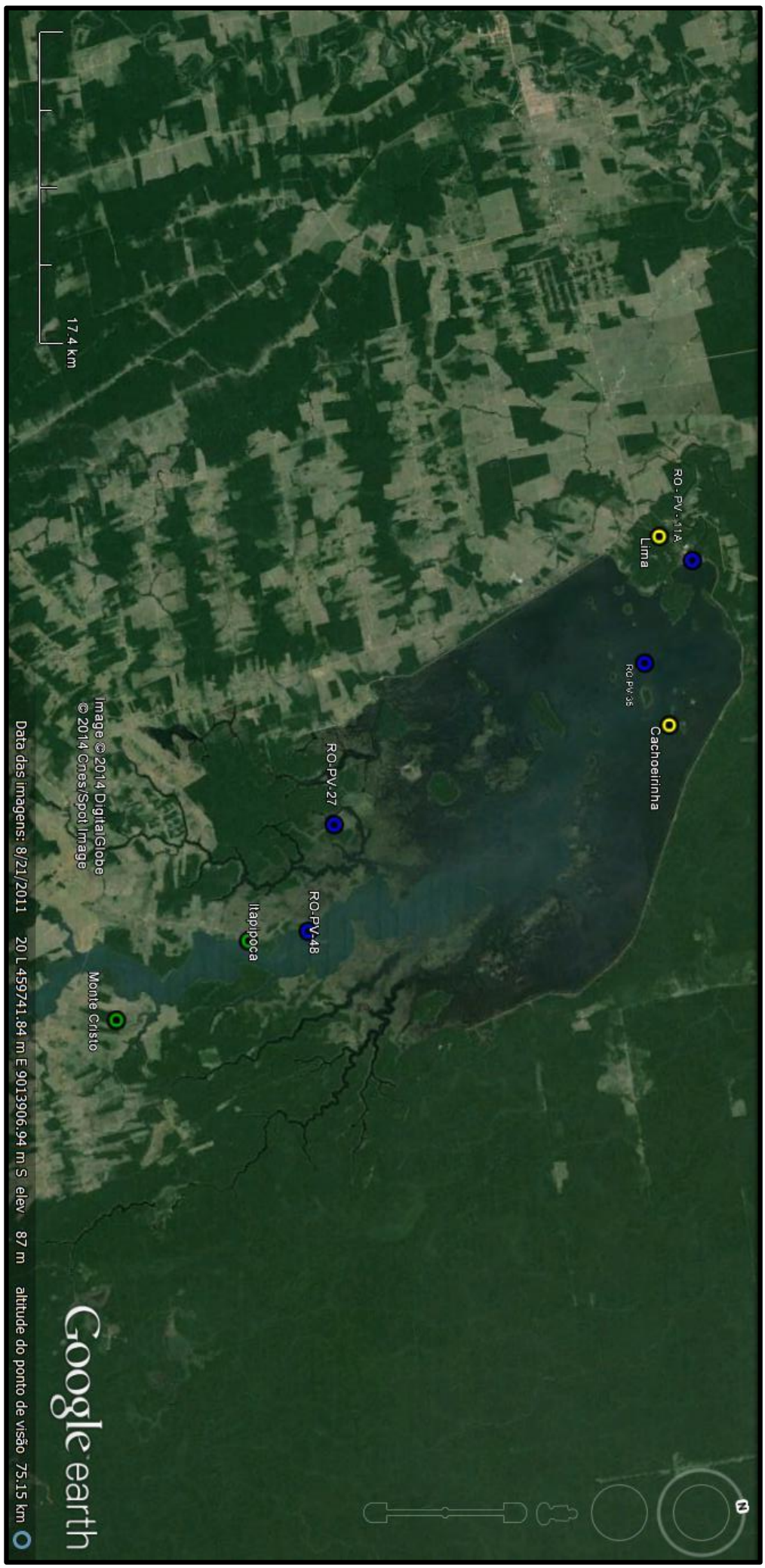


Anexo 3 - Reprodução do perfil do Sitio Cachoeirinha, com o estrato Massangana em destaque, e materiais arqueológicos das fases Pacatuba, Itapipoca e Massangana.

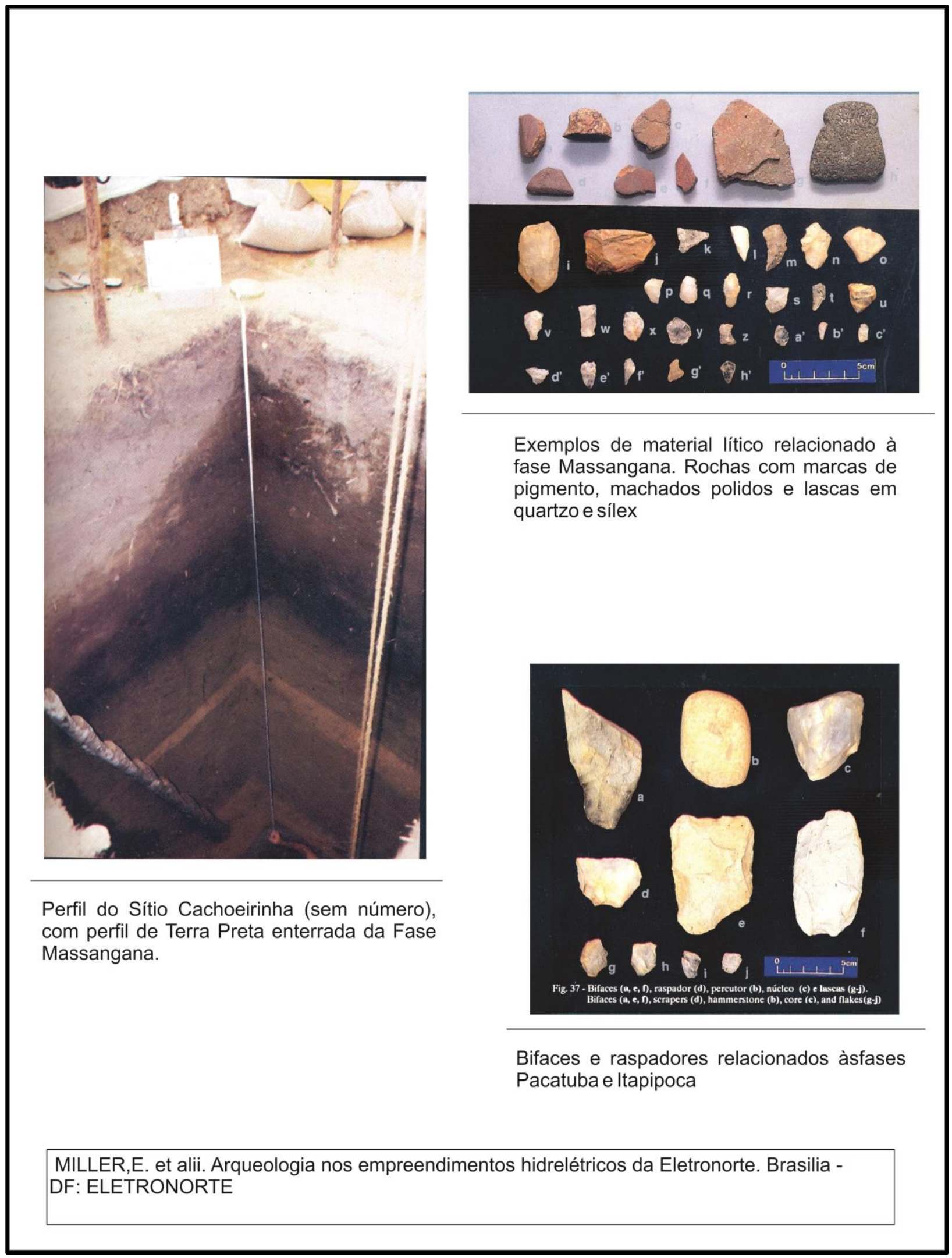


Anexo 4 - Croqui esquemático do Sítio Teotônio, Sítio Sta Paula, as respectivas Vilas, agora extintas, e a Nova Vila do Teotônio.

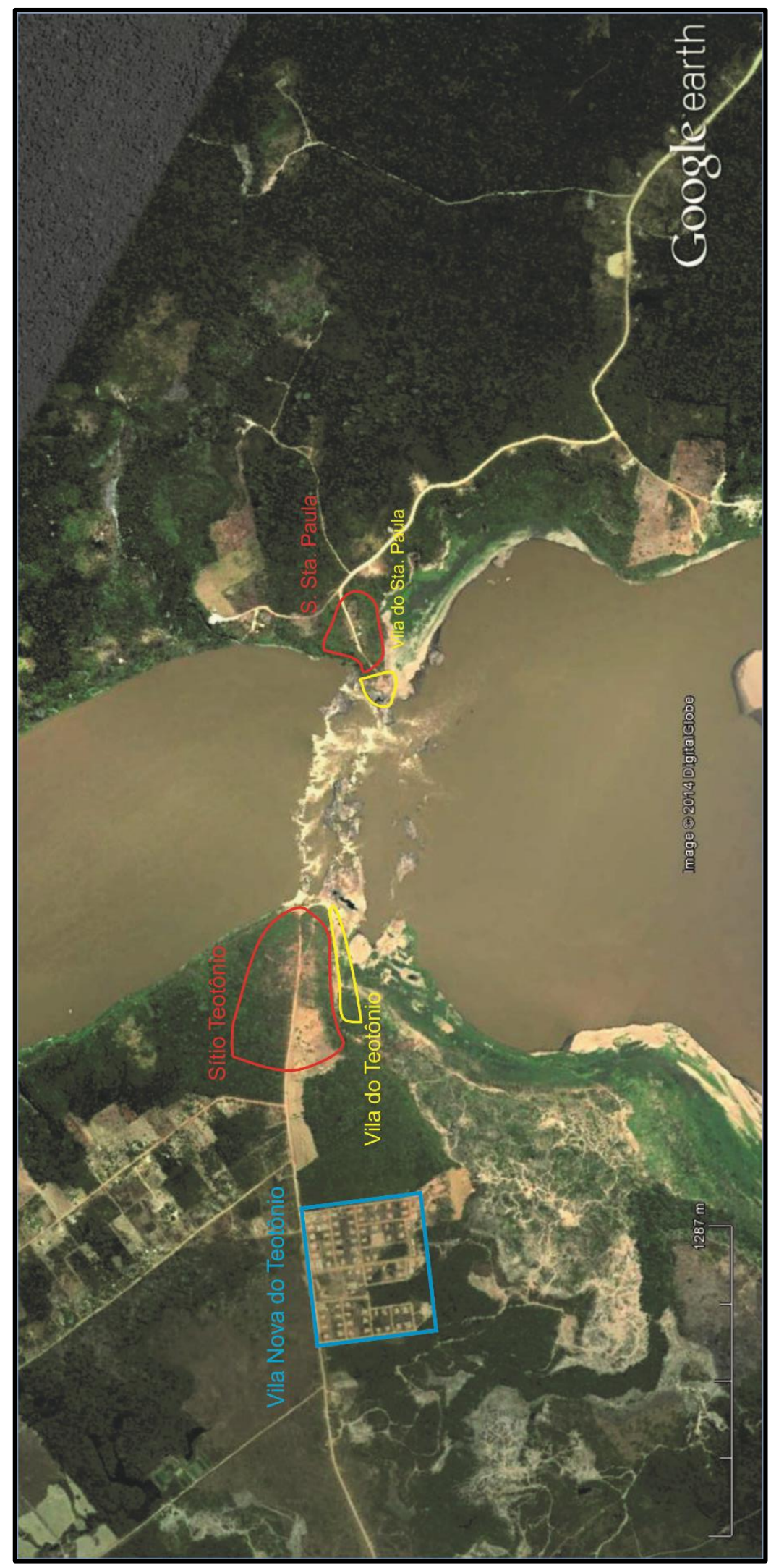


Anexo 5 - Repreentações da Cachoeira do Teotônio através dos séculos

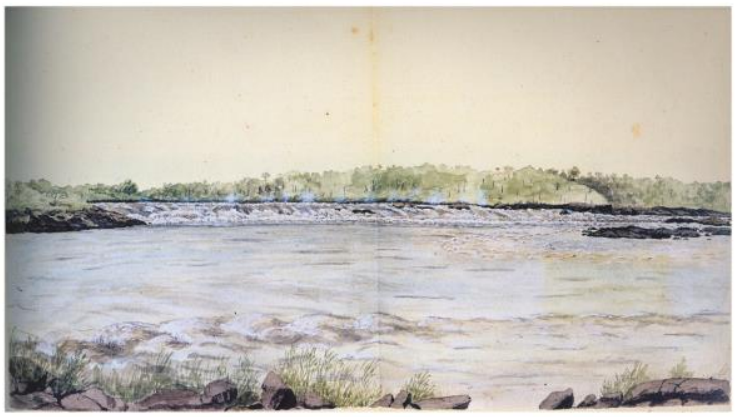

«Vista da Cachoeira do Salto do Theotonio, tirada da margem Sul, aos 22 de Novembro

-Alexandre Rodrigues Ferreira

"Vista do primeiro Canal da Cachoeira do Salto do Theotonio contando do Sul para Norte: Feita aos 27 de Novembro»

-Alexandre Rodrigues Ferreira
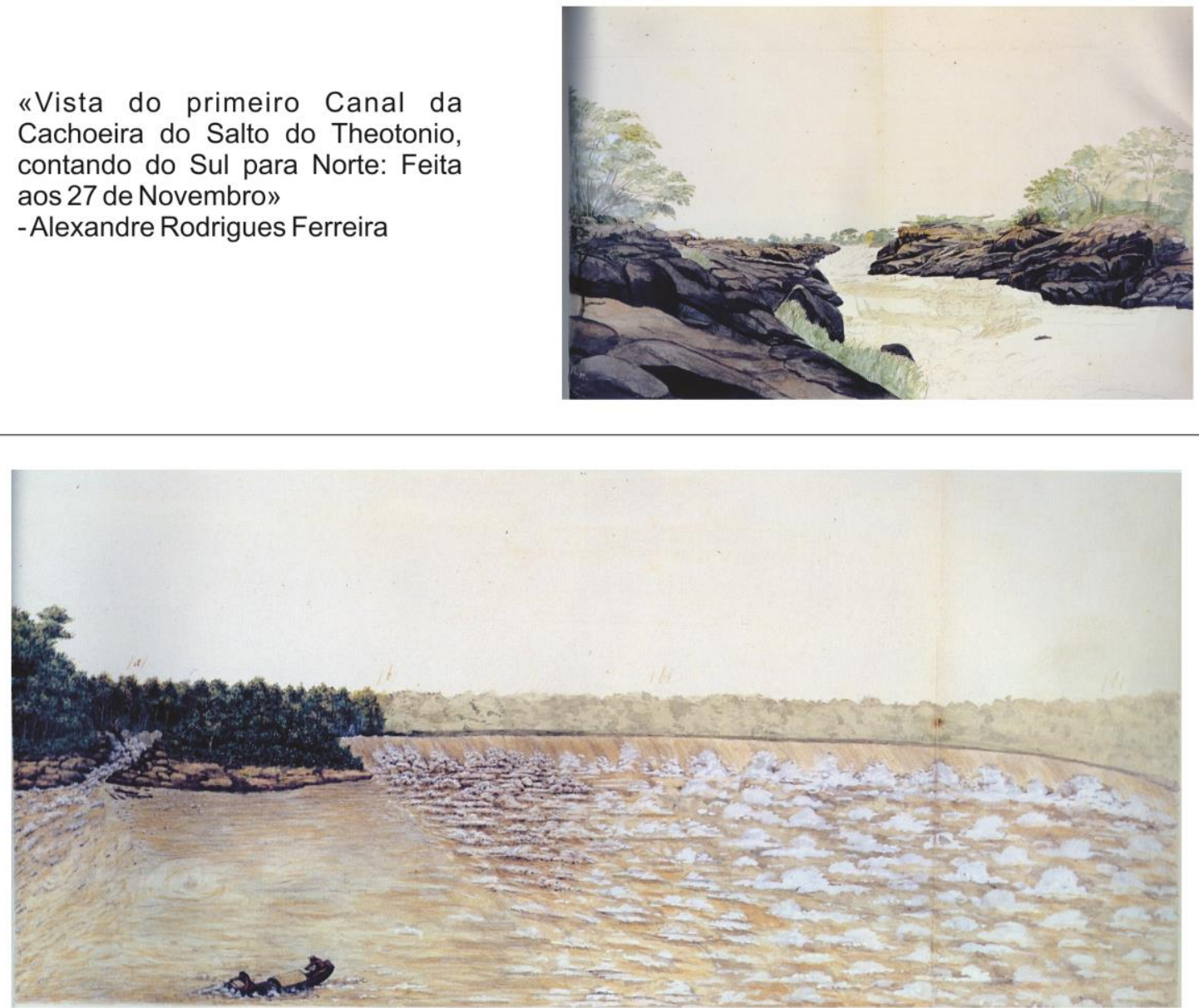

«Vista da Cachoeira do Sato (sic) do Theotonio, a 2ª do Rio da Madeira. Em 20 de Janeiro de 1789"

- Alexandre Rodrigues Ferreira

FERREIRA, Alexandre Rodrigues. Viagem ao Brasil: A Expedição Philosophica pelas Capitanias do Pará, Rio Negro, Mato Grosso e Cuyabá. Lisboa: Ed. Vitae.Vol II. 

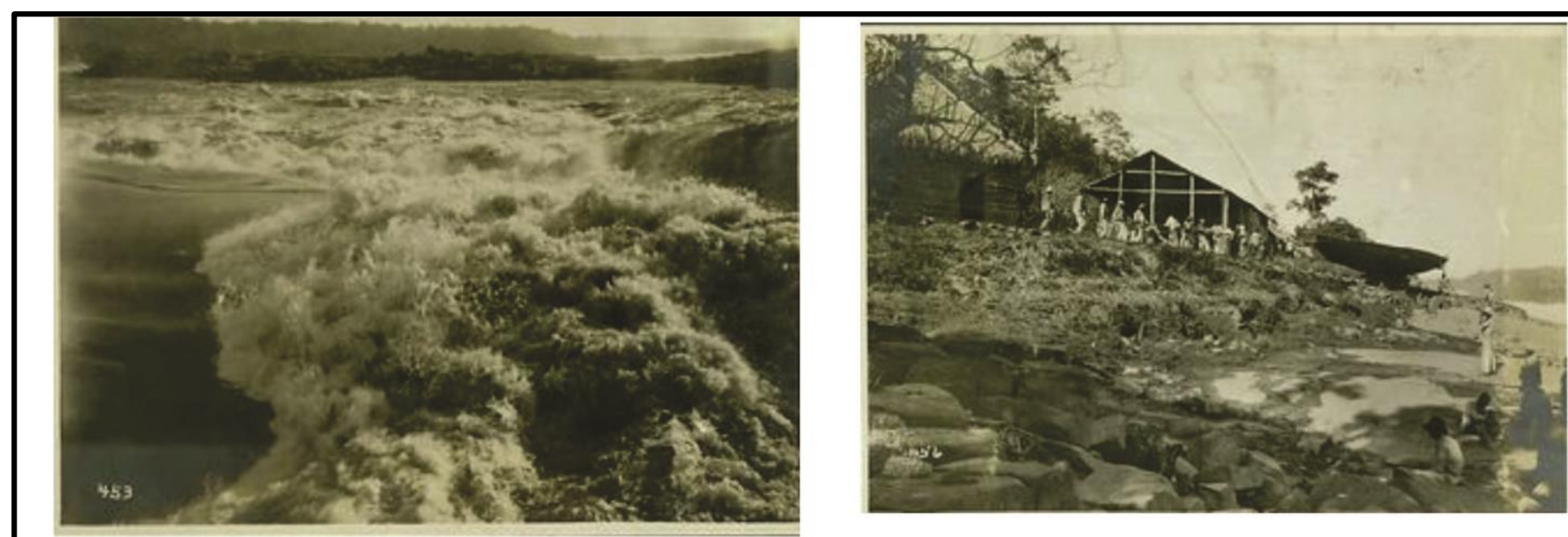

«THEOTONIA» Fotos de Dana Merrill - 1909 - Coleção Dana Merril / Museu Paulista / SP
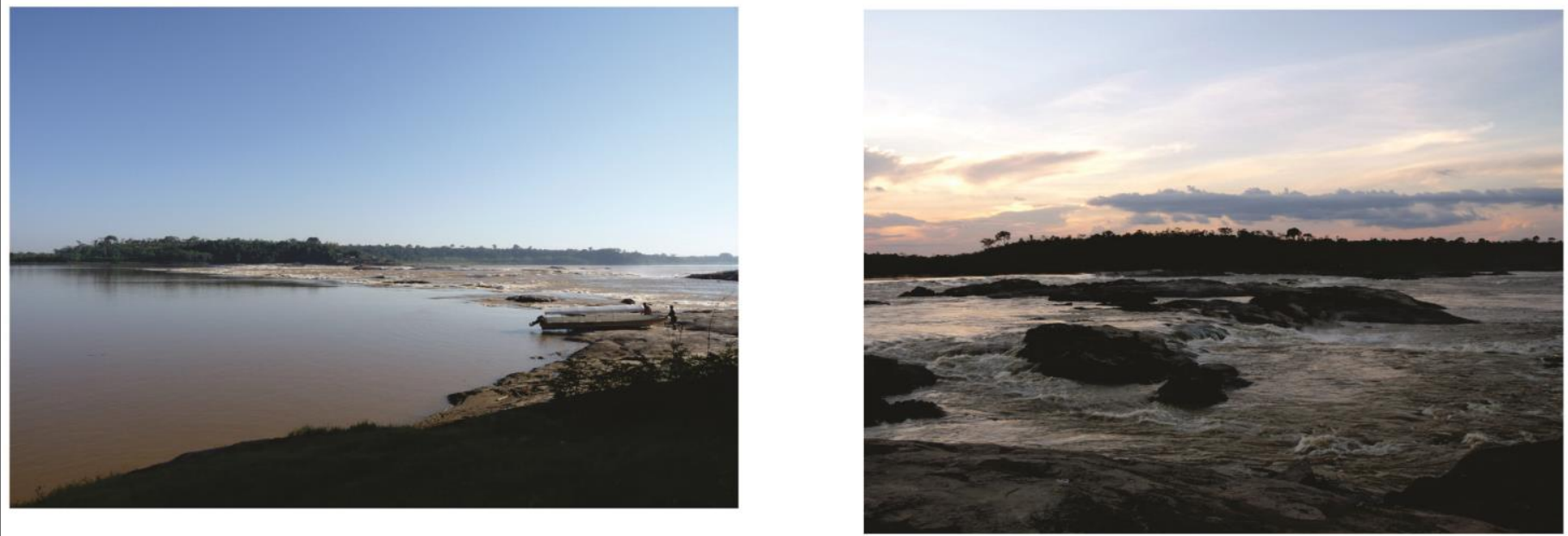

Cachoeira do Teotônio - Vista da cachoeira a partir da Vila do Teotônio - Fotos de Rodrigo Suñer -

Sítio Teotônio, a partir do Lago do reservatório da UHE Sto. Antônio - Fotos de Fernando Almeira - AGO/2013 
Anexo 6 - Mapa geral das intervenções no sítio Teotônio

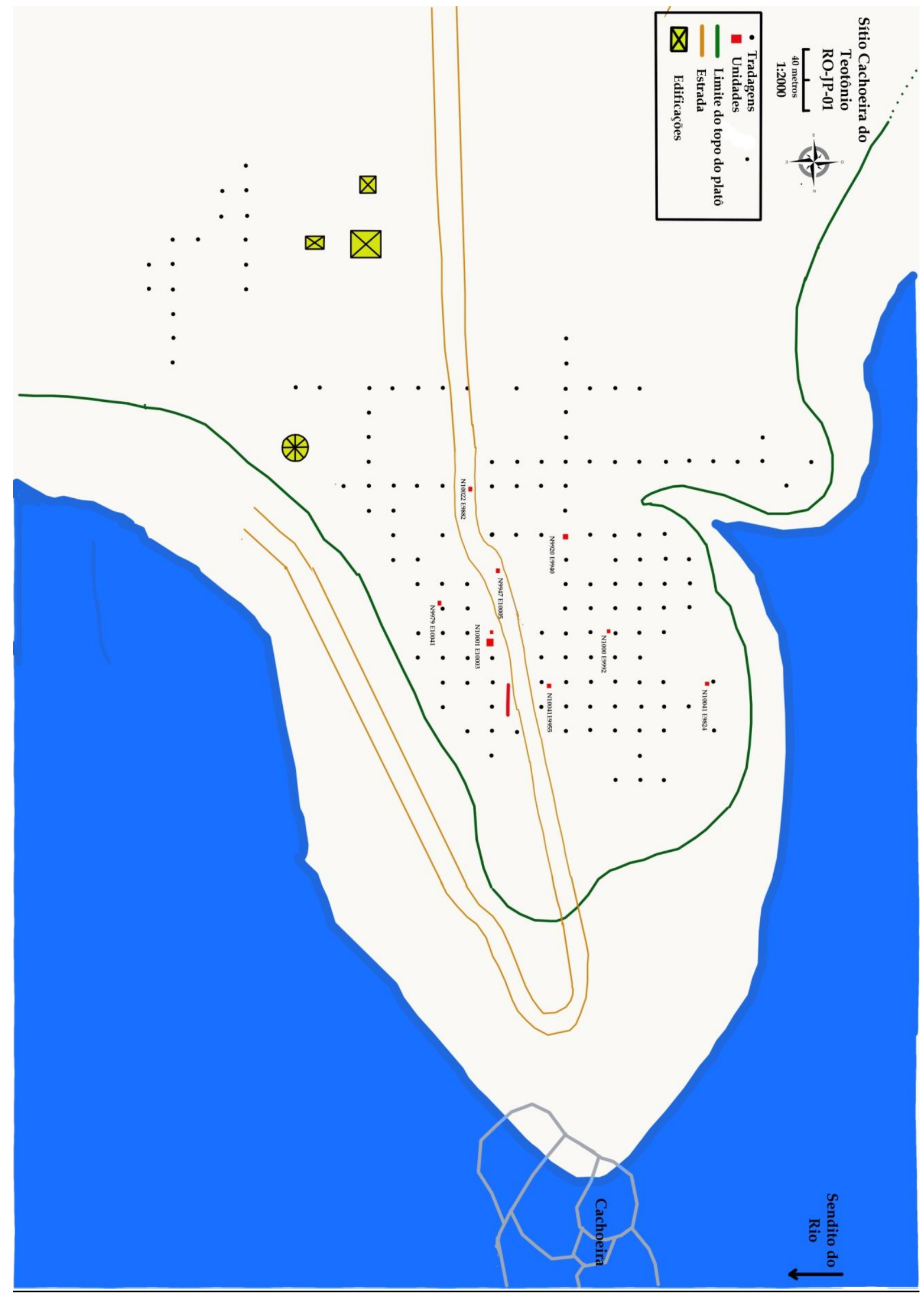


Anexo 7- Ficha de triagem de material cerâmico

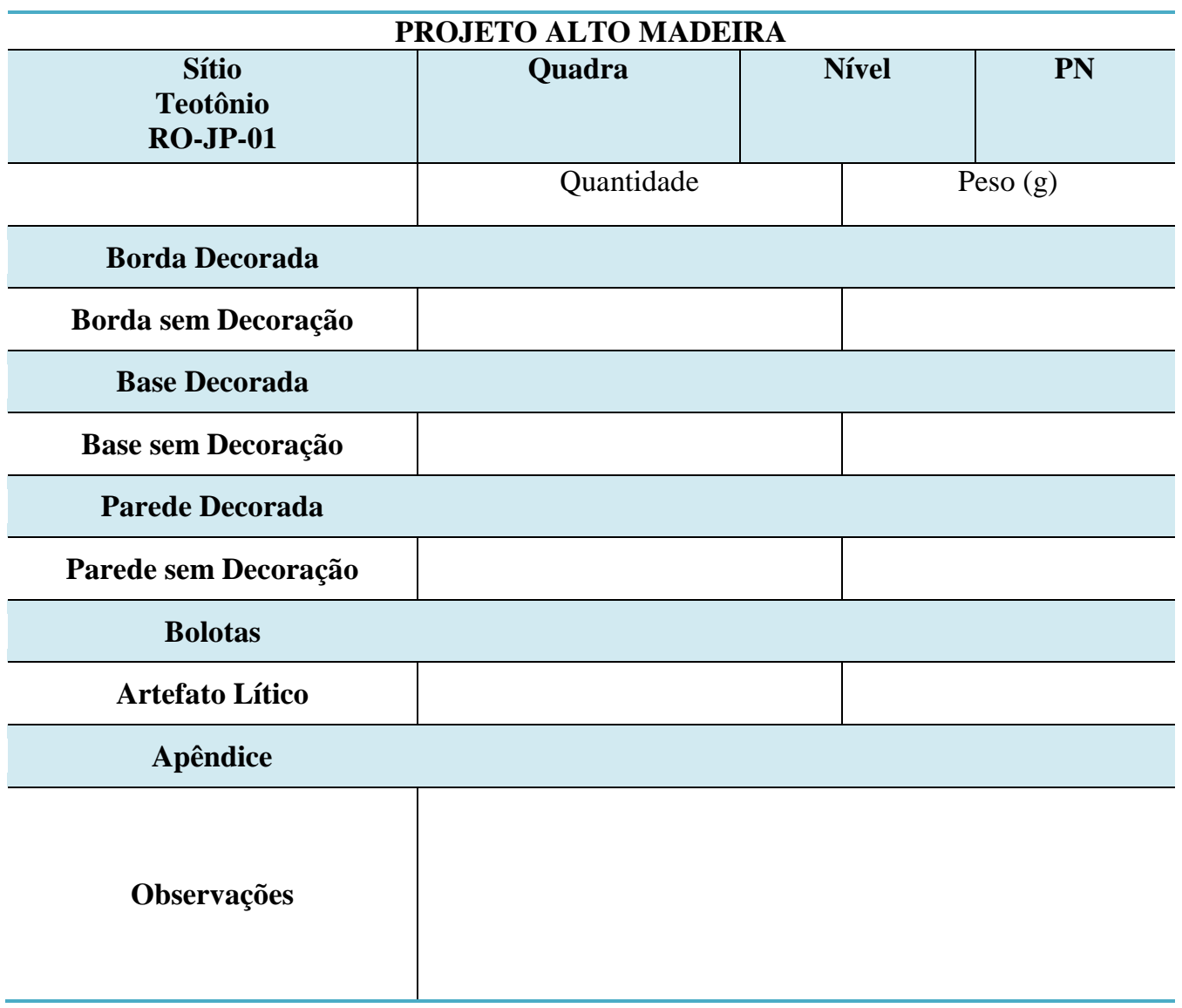


Anexo 8- Ficha de análise de material lítico

\section{Projeto Alto Madeira - Sítio Teotônio - RO-JP 01} FICHA DE ANÁLISE LÍTICA

\begin{tabular}{|l|l|}
\hline Unidade & \\
\hline Nível & \\
\hline PN & \\
\hline Chumanga & \\
\hline Total & \\
\hline
\end{tabular}

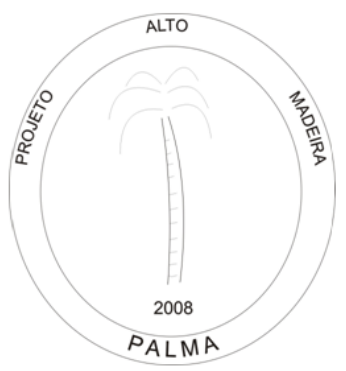

Artefato - Quantidade:

\begin{tabular}{|l|l|}
\hline Obs: \\
\hline \multicolumn{2}{|l|}{} \\
\hline \multicolumn{2}{|c|}{ Lascas Unipolares } \\
\hline
\end{tabular}

\section{Quartzo}

Total:

PALMA

Lascas Bipolares

\begin{tabular}{|l|l|}
\hline Menor de $1 \mathrm{~mm}$ & \\
\hline Maior de $1 \mathrm{~mm}$ & \\
\hline Maior de $2 \mathrm{~mm}$ & \\
\hline Maior de $3 \mathrm{~mm}$ & \\
\hline
\end{tabular}

Núcleos

\begin{tabular}{|l|l|}
\hline Menor de $1 \mathrm{~mm}$ & \\
\hline Maior de $1 \mathrm{~mm}$ & \\
\hline Maior de $2 \mathrm{~mm}$ & \\
\hline Maior de $3 \mathrm{~mm}$ & \\
\hline
\end{tabular}

\section{\begin{tabular}{|l|l|}
\hline Quartzo Hialino & Total: \\
\hline
\end{tabular}}

$\underline{\text { Lascas Unipolares }}$

$$
\underline{\text { Lascas Bipolares }}
$$

\section{Núcleos}

\begin{tabular}{|l|l|}
\hline Menor de $1 \mathrm{~mm}$ & \\
\hline Maior de $1 \mathrm{~mm}$ & \\
\hline Maior de $2 \mathrm{~mm}$ & \\
\hline Maior de $3 \mathrm{~mm}$ & \\
\hline
\end{tabular}

\begin{tabular}{|l|l|}
\hline Menor de $1 \mathrm{~mm}$ & \\
\hline Maior de $1 \mathrm{~mm}$ & \\
\hline Maior de $2 \mathrm{~mm}$ & \\
\hline Maior de $3 \mathrm{~mm}$ & \\
\hline
\end{tabular}

\begin{tabular}{|l|l|}
\hline Menor de $1 \mathrm{~mm}$ & \\
\hline Maior de $1 \mathrm{~mm}$ & \\
\hline Maior de $2 \mathrm{~mm}$ & \\
\hline Maior de $3 \mathrm{~mm}$ & \\
\hline
\end{tabular}

\section{\begin{tabular}{|l|l}
\hline Quartzo Leitoso & Total: \\
\hline
\end{tabular}}

Lascas Unipolares

Lascas Bipolares

Núcleos

\begin{tabular}{|l|l|}
\hline Menor de $1 \mathrm{~mm}$ & \\
\hline Maior de $1 \mathrm{~mm}$ & \\
\hline Maior de $2 \mathrm{~mm}$ & \\
\hline Maior de $3 \mathrm{~mm}$ & \\
\hline
\end{tabular}

\begin{tabular}{|l|l|}
\hline Menor de $1 \mathrm{~mm}$ & \\
\hline Maior de $1 \mathrm{~mm}$ & \\
\hline Maior de $2 \mathrm{~mm}$ & \\
\hline Maior de $3 \mathrm{~mm}$ & \\
\hline
\end{tabular}

\begin{tabular}{|l|l|}
\hline Menor de $1 \mathrm{~mm}$ & \\
\hline Maior de $1 \mathrm{~mm}$ & \\
\hline Maior de $2 \mathrm{~mm}$ & \\
\hline Maior de $3 \mathrm{~mm}$ & \\
\hline
\end{tabular}


Anexo 10-Desenhos de Perfil

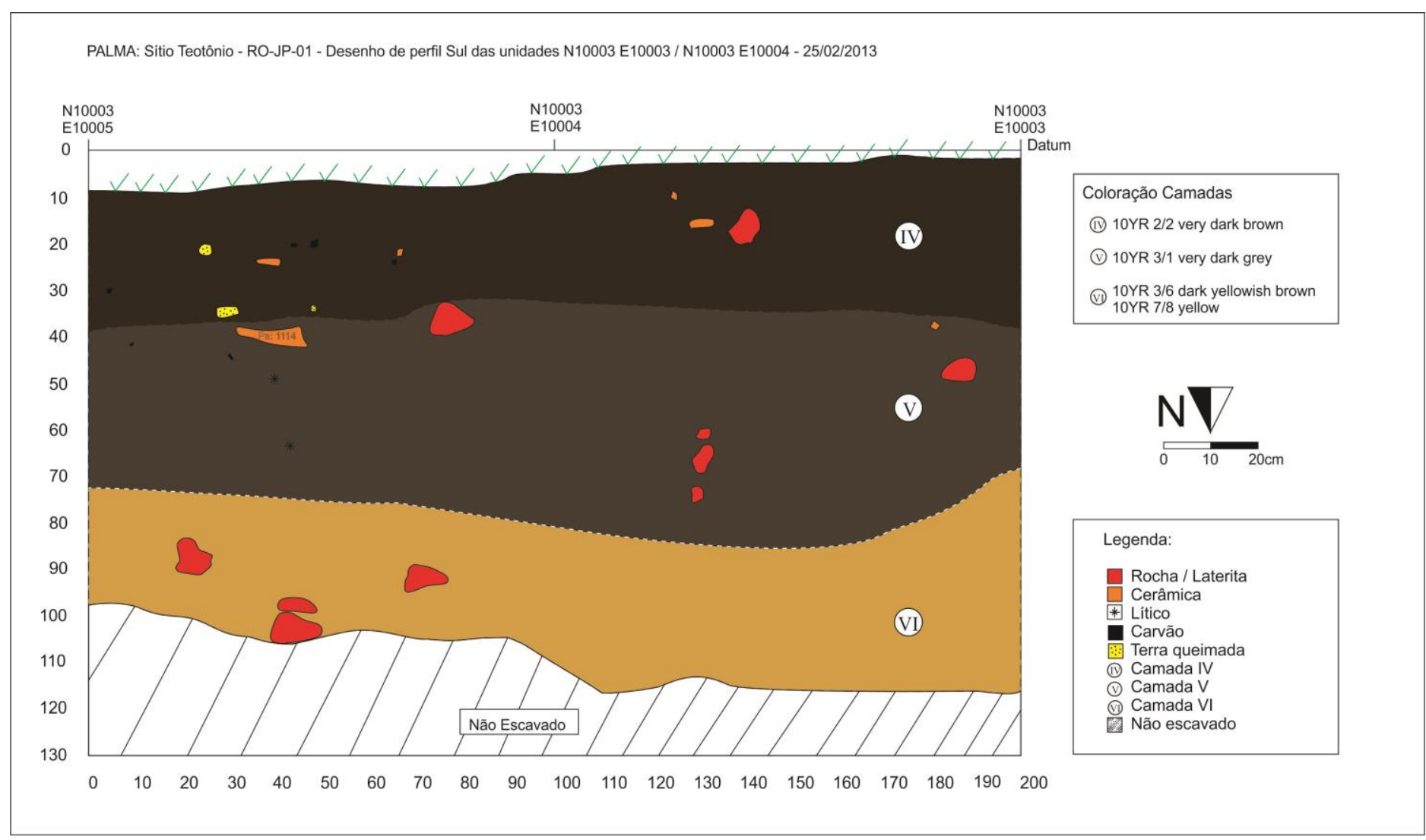



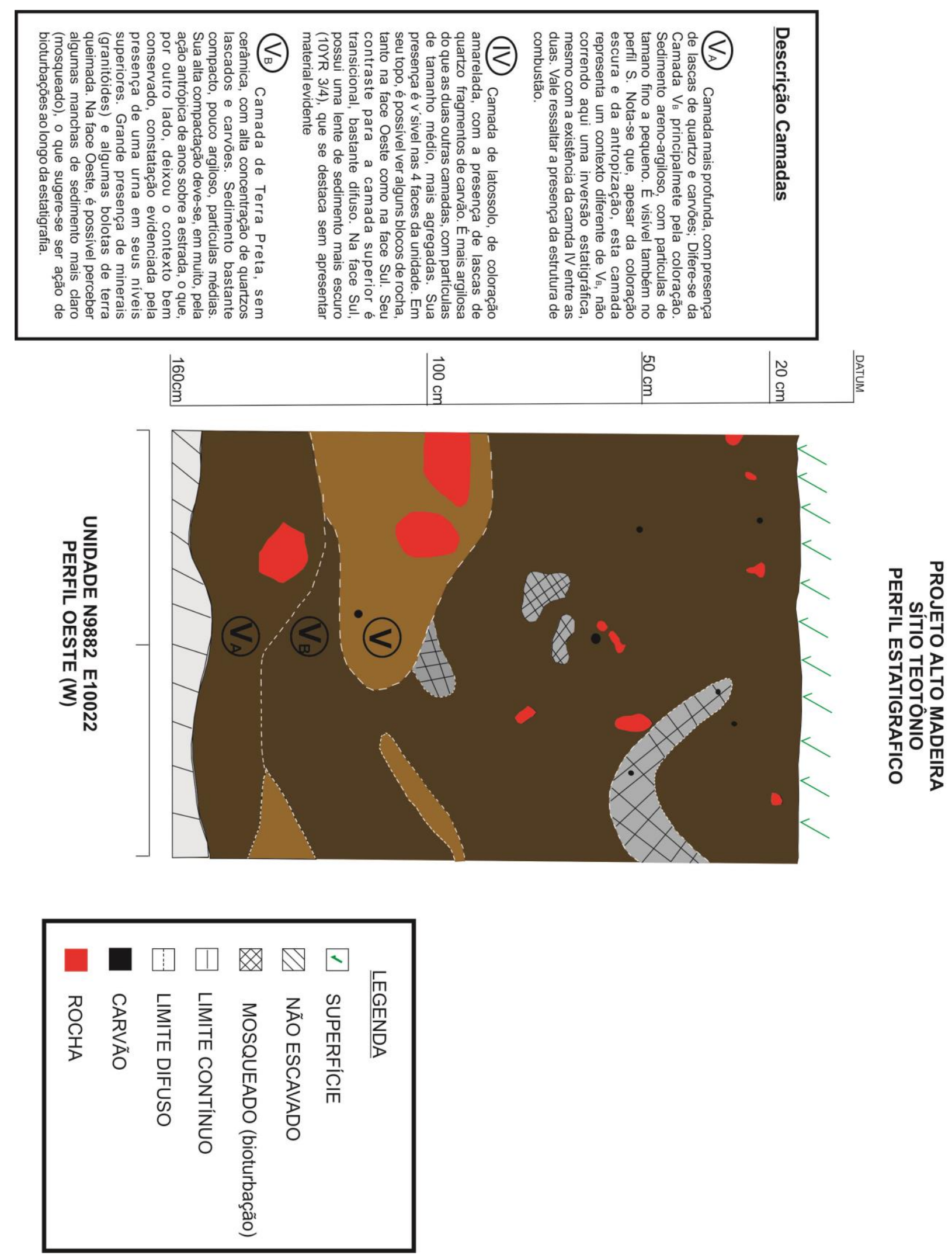


\section{Sítio Teotônio - Perfil N10045 E9987}

VIII Corresponde à terraplanagem, base da antiga estrada de acesso à casa do ex-morador. Espessura variável, com muitas raizes e radículas, fragmentos cerâmicos e laterita. Coloração 10YR 4/4 "dark yellowish brown”. Partículas variando de fina à grossa.

VI Camada com Terra Preta 10YR 2/1 "black", com solo argiloso e compacto e partículas finas a médias. Apresenta fragmentos cerâmicos, laterita, raizes e radículas.

V Camada com Terra Preta 10YR2/2 "very dark brown" com solo argilo-arenoso. Apresenta material lítico, laterita e pequenos carvões

II Camada arqueologicamente estéril, formada por laterita, com colaração 7,5 YR 4/3 "brown". Apresenta carvões.

(I) Camada estéril arqueologicamente, formada por cascalho laterítico, com coloração 7,5 YR 6/6 "reddish yellow).

Área não escavada.

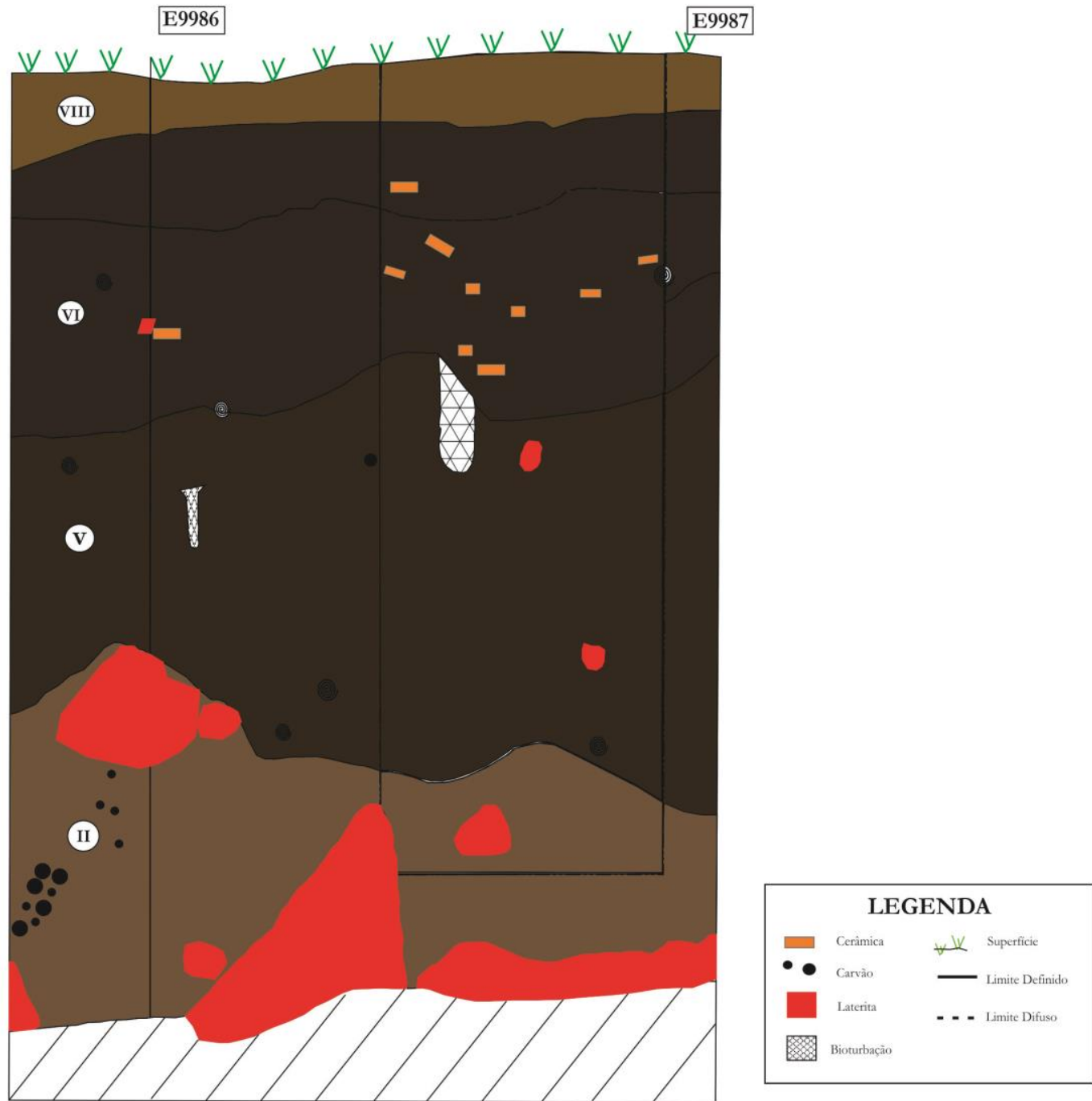




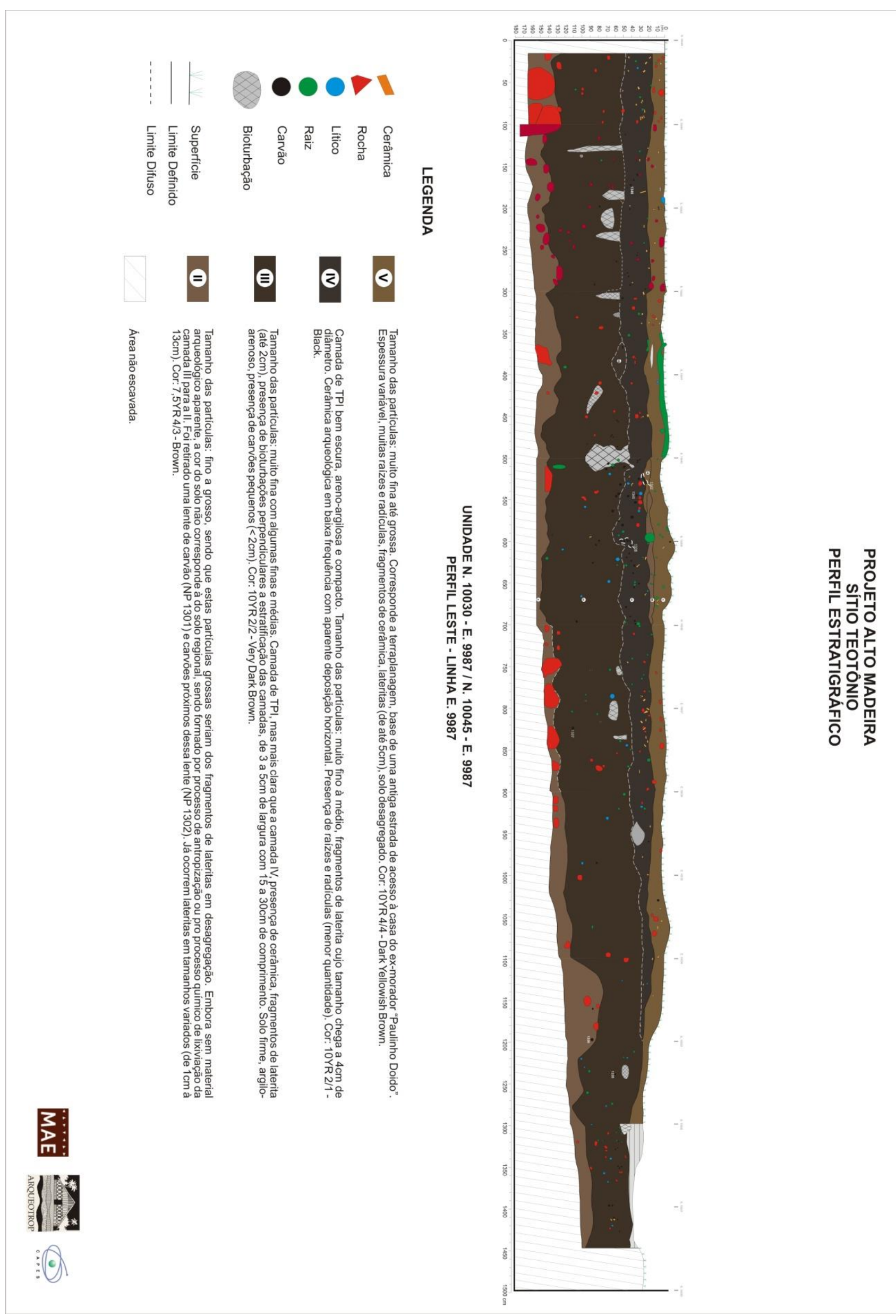


Anexo 11 - Pranchas de exemplo de cerâmicas dos três picos da Unidade N10041 E9955 (30-40cm / 150-160cm / 200-210cm)

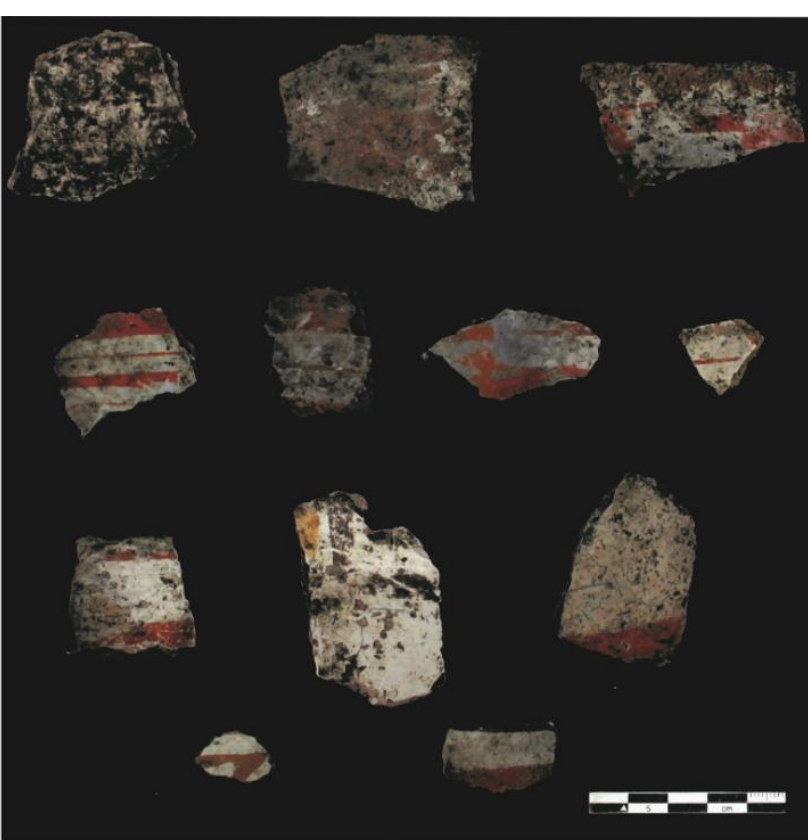

Sítio Teotônio - Unidade N10041 E9955 Nível $30-40 \mathrm{~cm}$. Paredes decoradas.

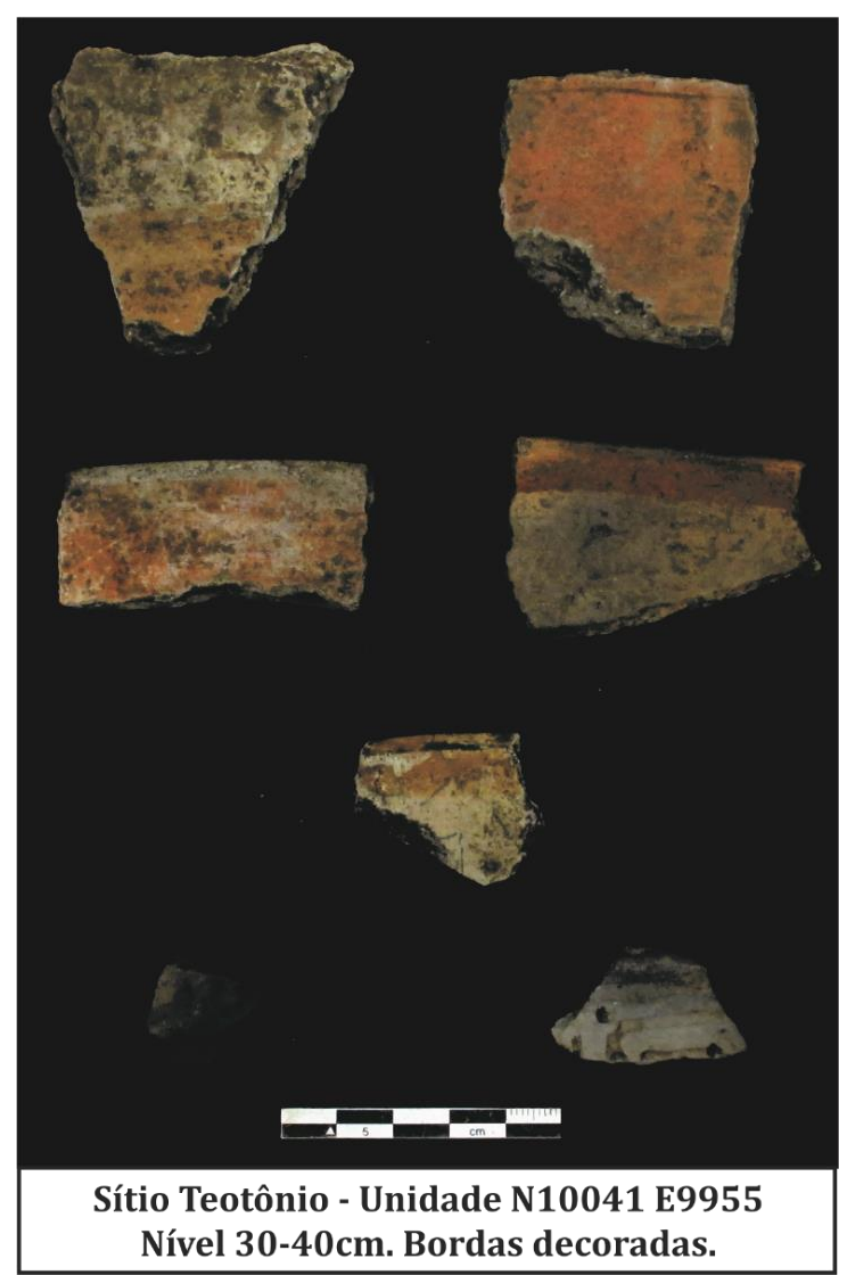

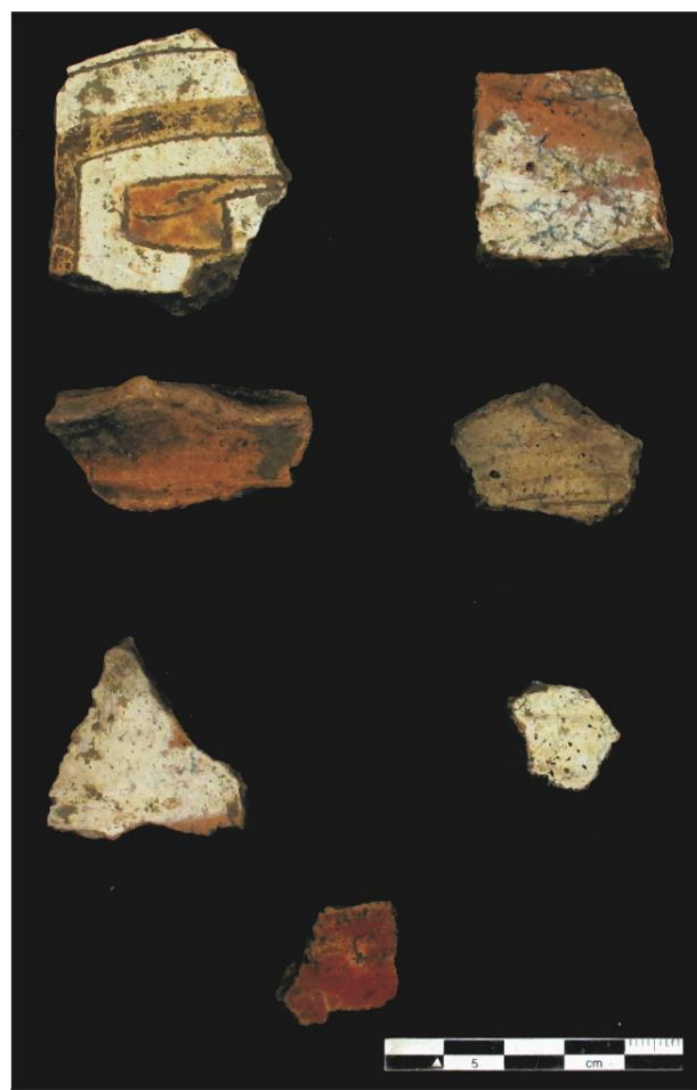

Sítio Teotônio - Unidade N10041 E9955 Nível 150-160cm. Paredes Decoradas Pintadas.

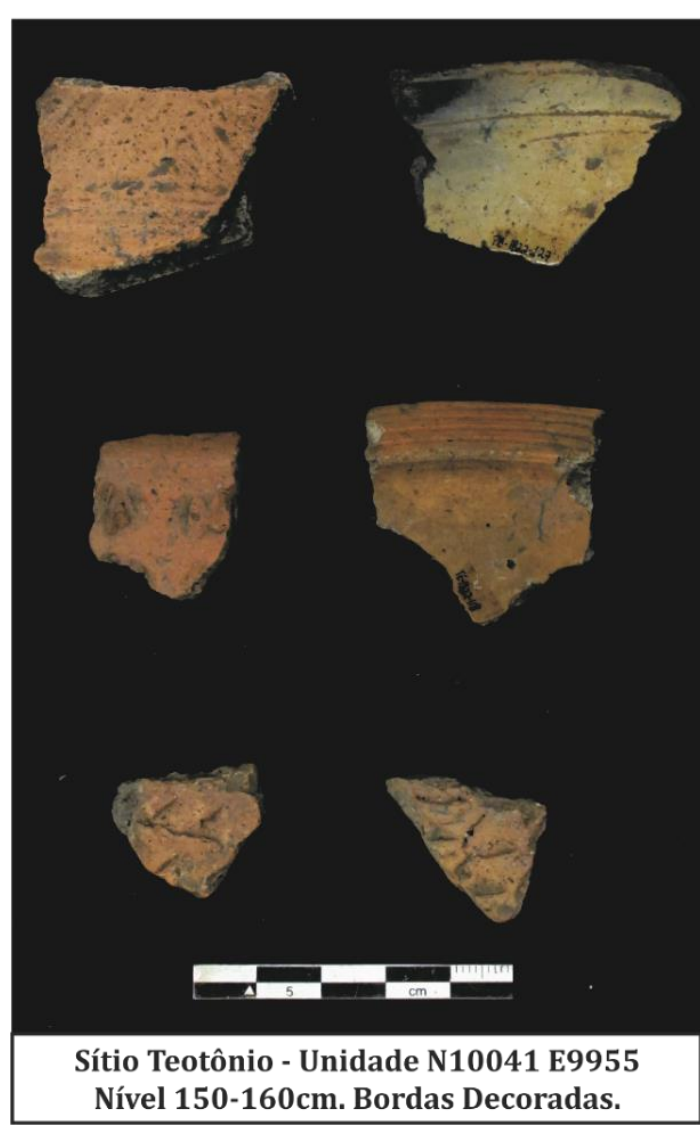



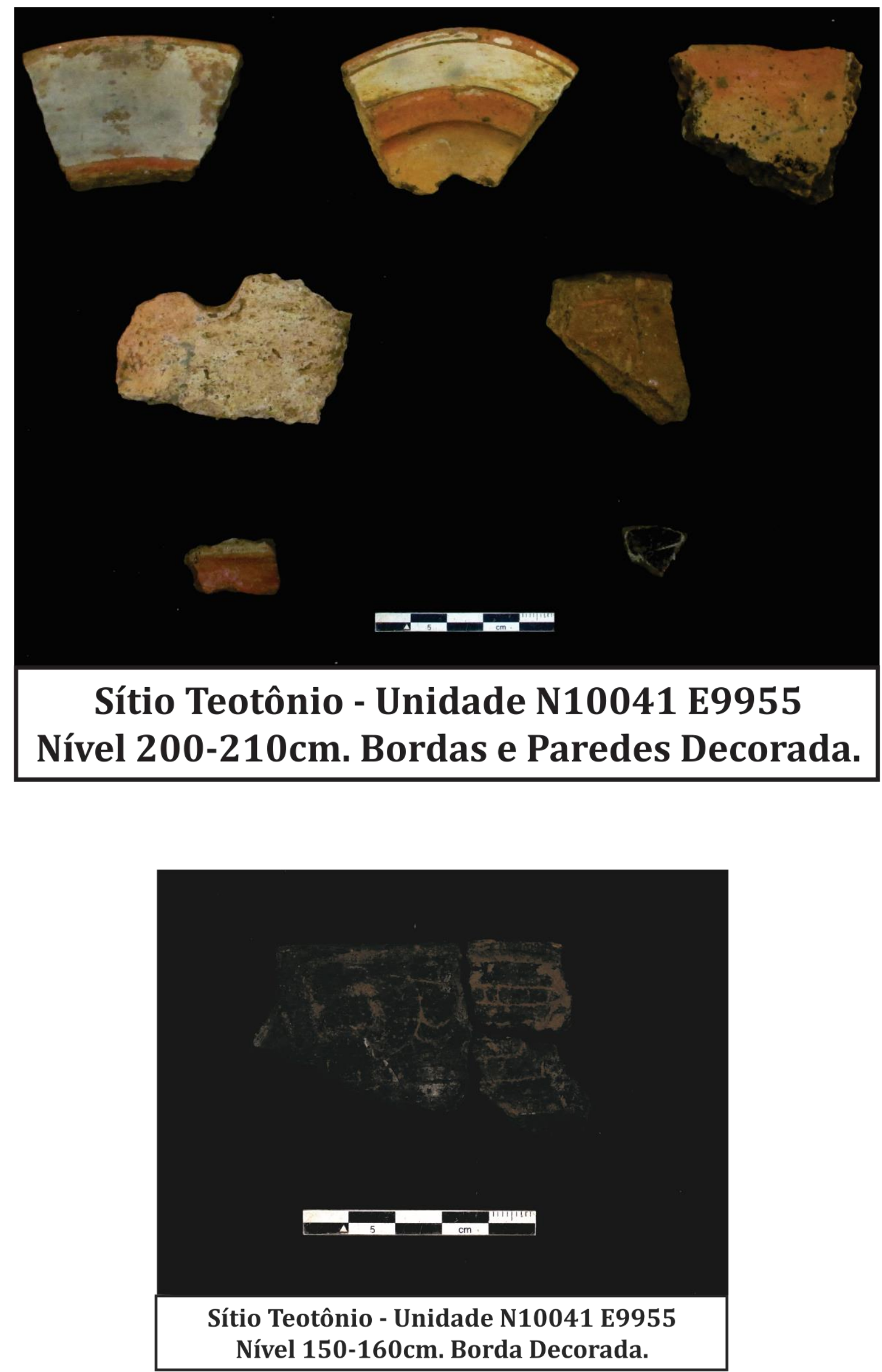

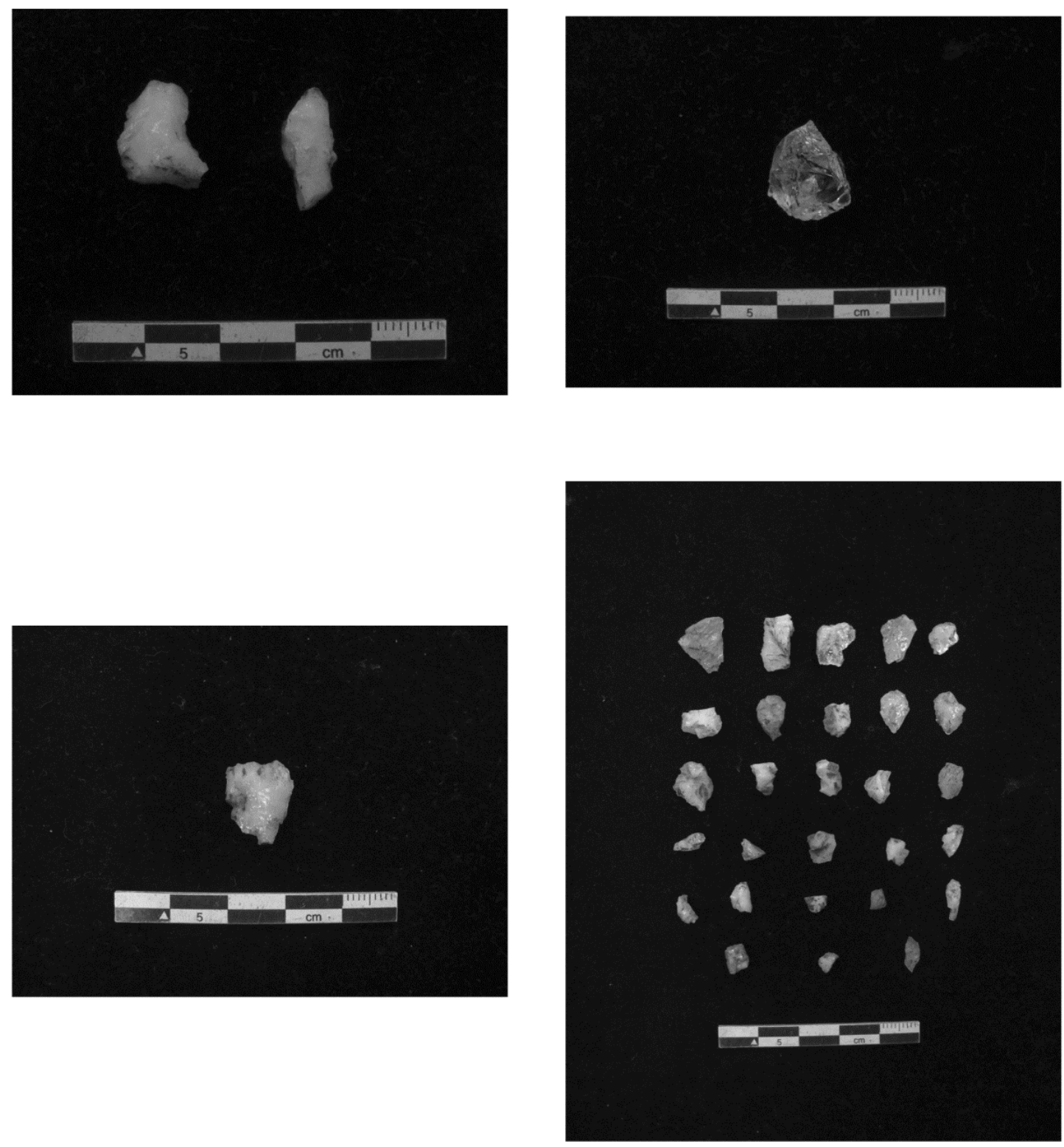

Líticos da camada ceramista.

Quadro 1- Lascas bipolares quartzo leitoso (N10003 E10003 -PN 1206)

Quadro 2 - Núcleo quartzo halino (N10003 E10003 - PN1203)

Quadro 3 - Artefato em quazrto, com pelo mneos 3 retiradas em sua parte distal, formando bordo (N10003 E10003 - PN1203

Quadro 4 - Lascas unipolares em quarzto (N10003 E10003 - PN 1203) 

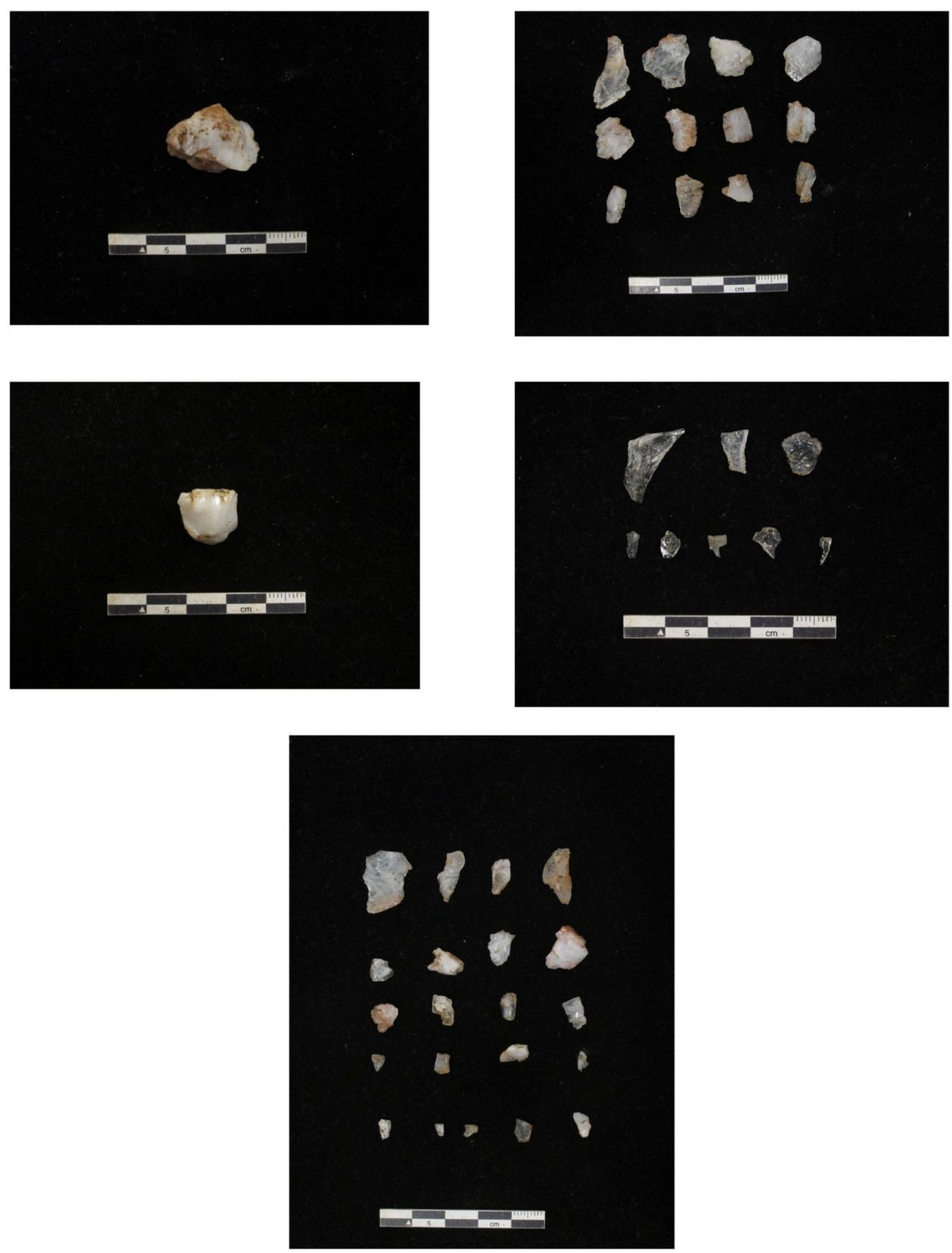

IÍTICOS DA CAMADA PRÉ-CERÂMICA

Quadro 1 - Artefato em quartzo, com bordo direito retocado (Unidade N10003 E10004 -PN 1107)

Quadro 2 - Lascas Bipolares em quaztzo (Unidade N10003 E10004 - PN 1107)

Quadro 3 - Núcleo em quartzo leitoso (Unidade N10003 E10003 - PN 1207)

Quadro 4 - Lascas unipolares em quarzto hialino (Unidade N10003 E10004 - PN 1108)

Quadro 5 - Lascas unipolares em quarzto (Unidade N10003 E10004) 


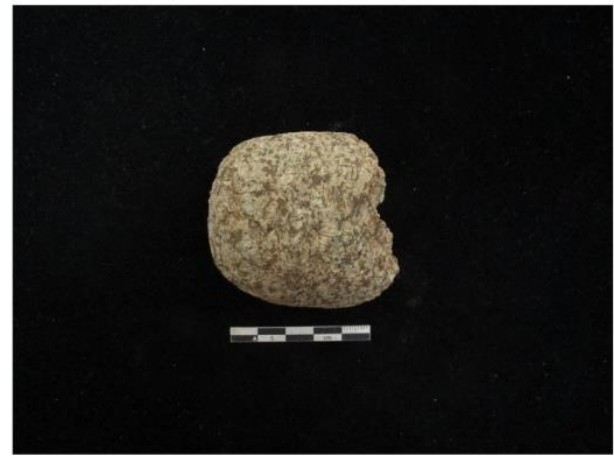

1

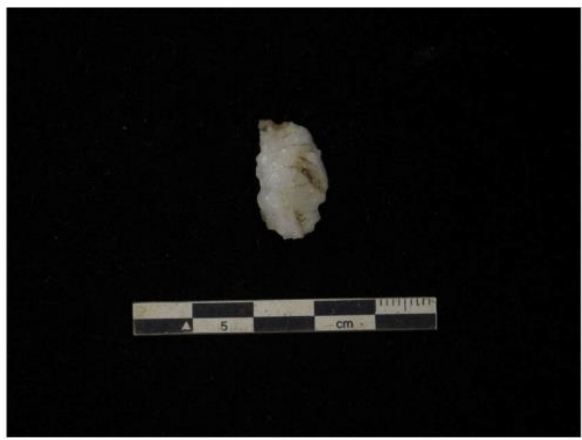

3

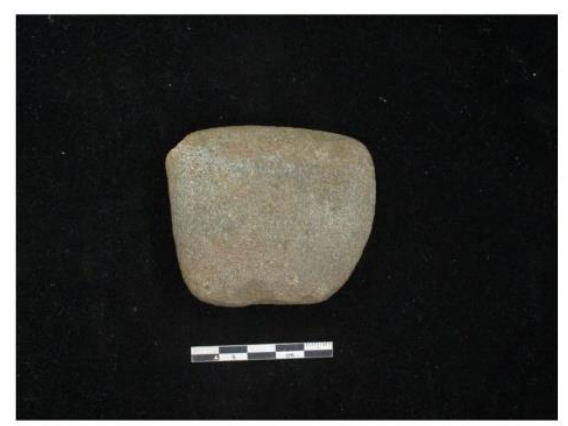

5

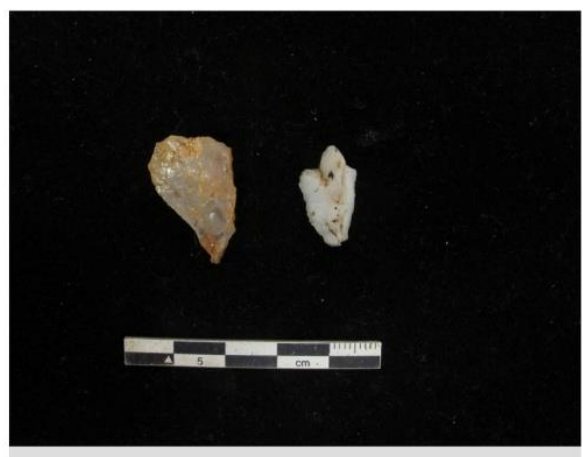

2

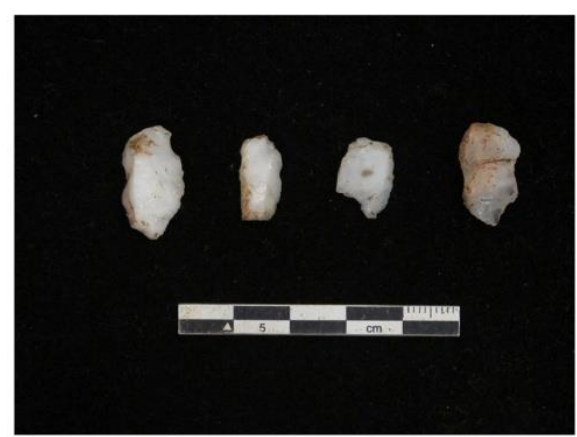

4

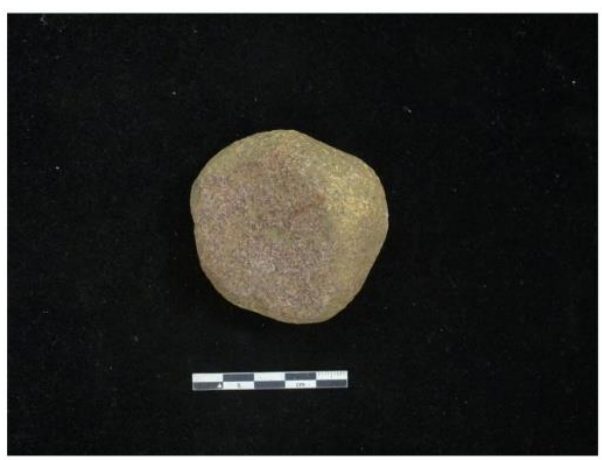

6

\section{ARTEFATOS}

Quadro 1- Fragmento de artefato em rocha granítica, polido, com marcas de percussão (N10003 E10004 - PN1107) Quadro 2 - Artefatos em lasca unipolar, com lãmina no bordo direito (N10003 E10004 - PN1107)

Quadro 3 - Artefato em lasca bipolar, com bordo direito trabalhado (N10003 E10003 - PN1203)

Quadro 4 - Artefatos em lasca unipolar, com bordo direito retocado (N10003 E10004 - PN 1103)

Quadro 5 - Lâmina de machado polida (coleta assistemática de superficie)

Quadro 6 - Artefato em rocha granítica, cupuliforme, com mascas de pigmentação na face fotografada quebra-coquinho (coleta assistemática de superfície) 


\section{Anexo 13}

Artefatos da Unidade N9882 E10022
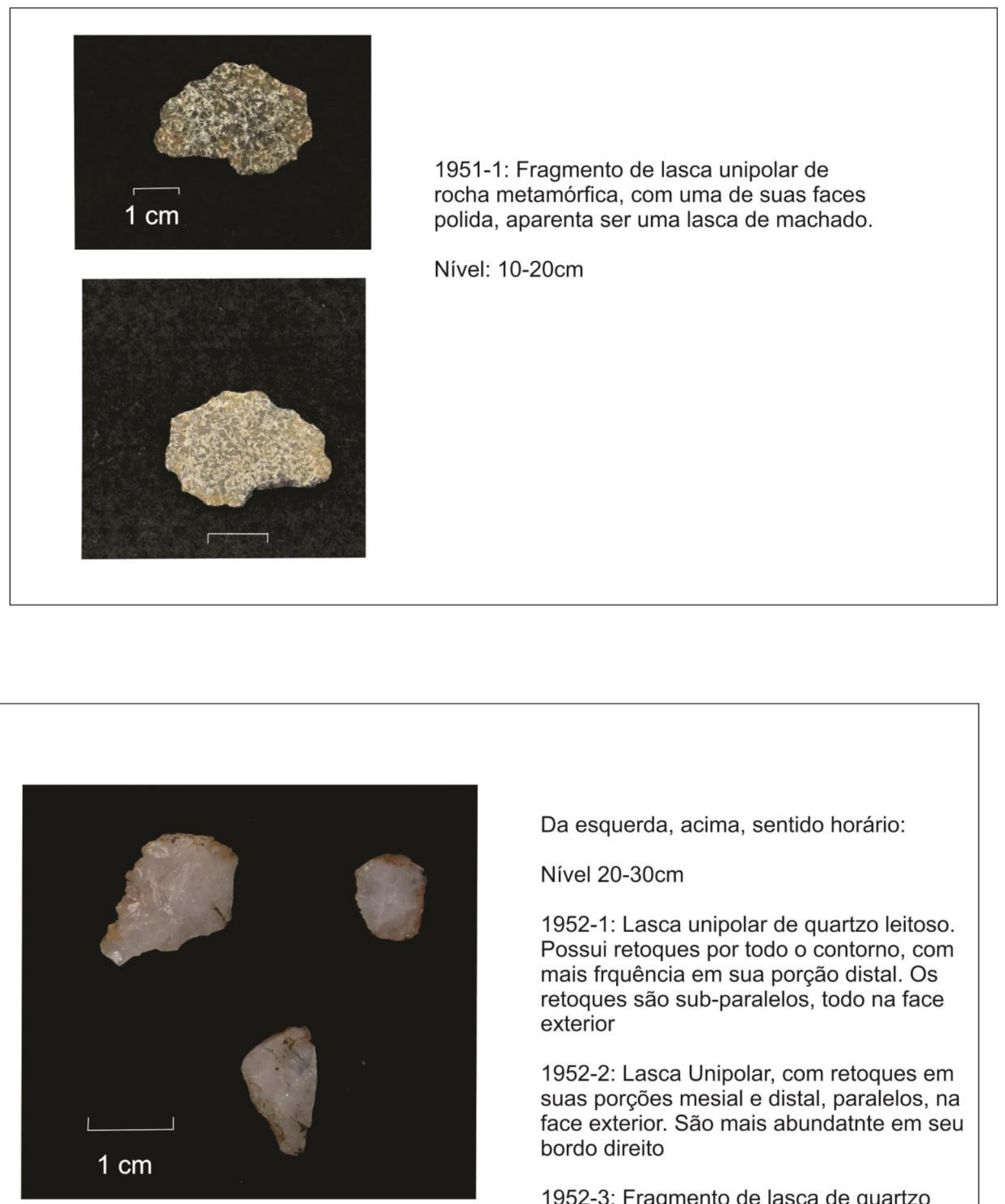

Da esquerda, acima, sentido horário:

Nível $20-30 \mathrm{~cm}$

1952-1: Lasca unipolar de quartzo leitoso. Possui retoques por todo o contorno, com mais frquência em sua porção distal. Os retoques são sub-paralelos, todo na face exterior

1952-2: Lasca Unipolar, com retoques em suas porções mesial e distal, paralelos, na face exterior. São mais abundatnte em seu bordo direito

1952-3: Fragmento de lasca de quartzo leitoso, com retoques paralelos e escamados, forma um gume em seu bordo esquerdo 


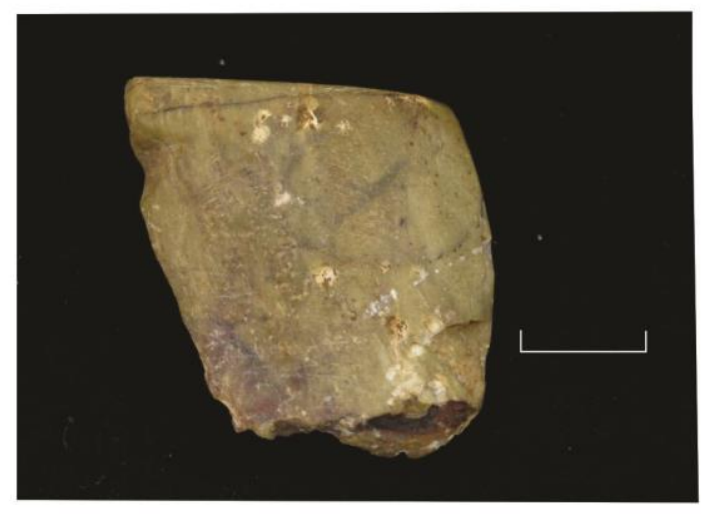

Nivel $30-40 \mathrm{~cm}$

1955-1 Fragmento de artefato polido, com orifício em sua porção proximal

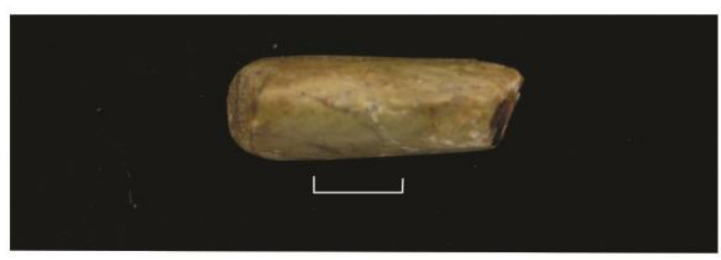

$30-40 \mathrm{~cm}$

1955-2: Lasca unipolar de quartzo hialino, com retoques em seu bordo direito. No bordo esquerdo, há o negativo de retirada de uma fina lamela, dando um formato reto e plano ao bordo

1955-3: Lasca típica de adelgaçamento unipolar de quartzo hialino,

1955-4: Fragmento de lasca cortical com pelo menos nove retiradas na porção proximal da lasca, aparenta ser um raspdador

1955-5: Fragmento de lasca com retoques em todas as suas extremidades, de formato subparalelo. 


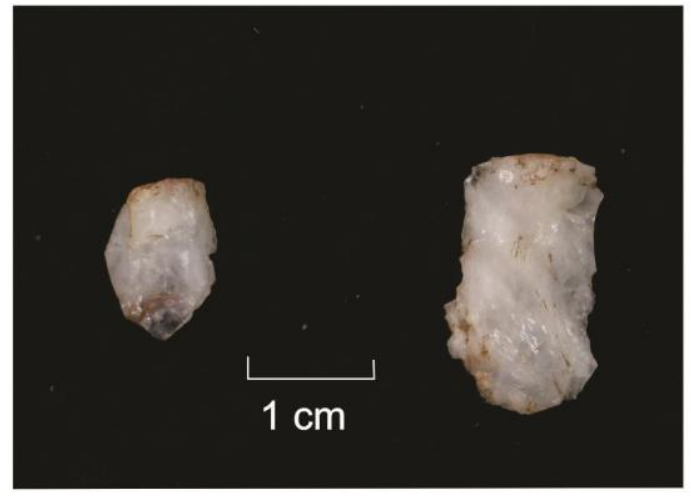

Nível 40-50cm

1956-2: (esquerda) Lasca unipolar de quartzo, talão fraturado, retoques em sua porção mesial

1956-4: (direita) Lasca unipolar de quartzo policristalino, talão fraturado. Retoques em ambos os bordos.
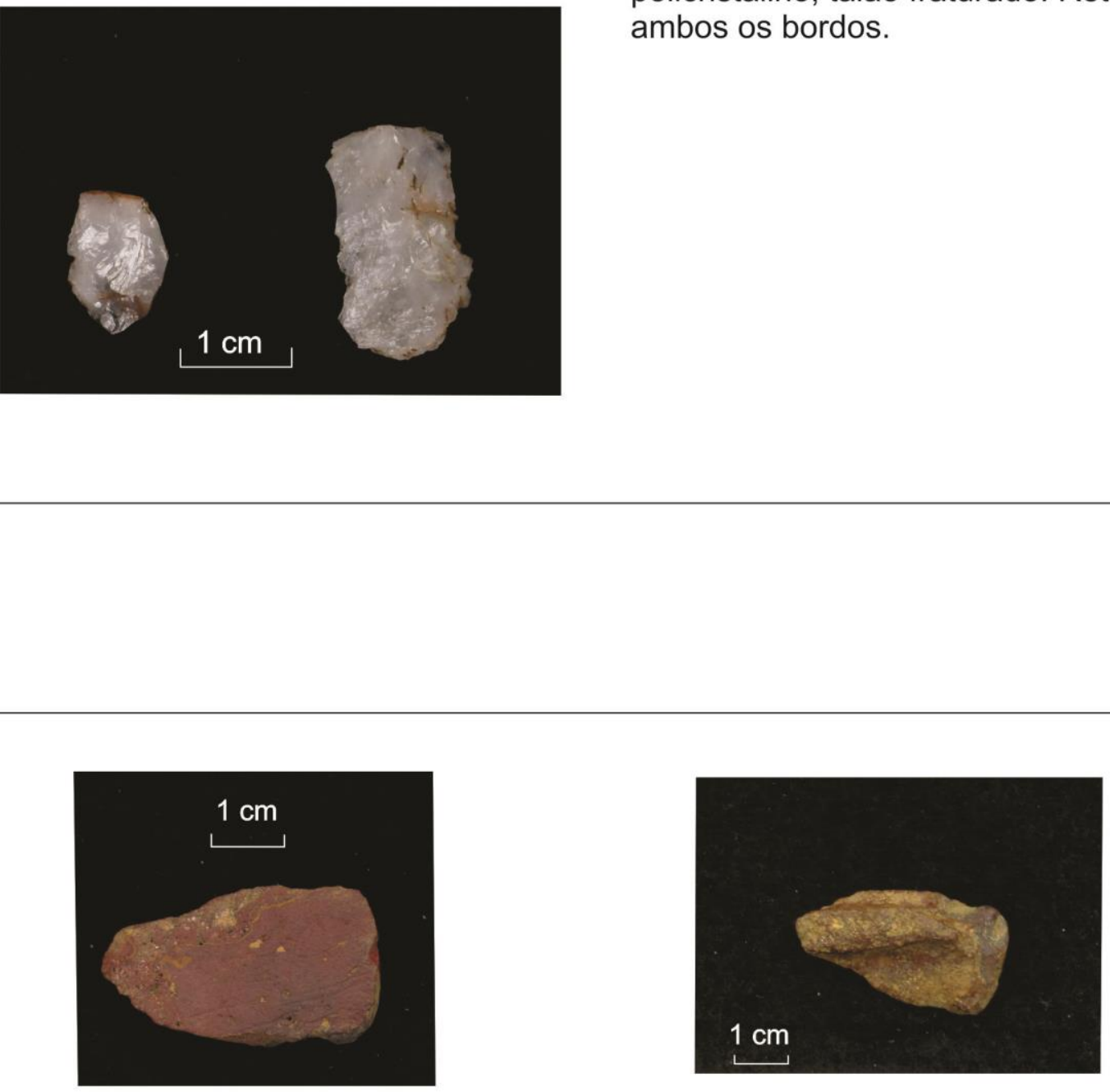

Nível $50-60 \mathrm{~cm}$

1957-1: Artefato de óxido de Ferro com marcas de estriamento em uma de suas faces.

Provavelmente utilizado para obtenção de pigmentação 
Nível 50-60 cm

1957-2: Fragmento de lasca de quartzo leitoso, com retoques em sua porção distal.

Aparenta ser um raspador.

1957-3: Lasca unipolar de quartzo leitoso com retirada em seu bordo direito

1957-4: Núcleo esgotado de formato discóide, provavelmnte utilizado como raspador

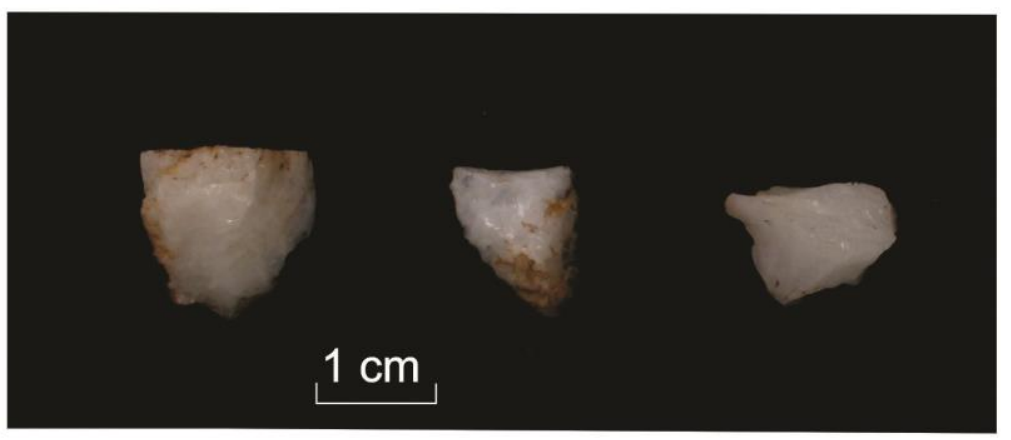

Detalhe do plano de percussão da peça 1957-4
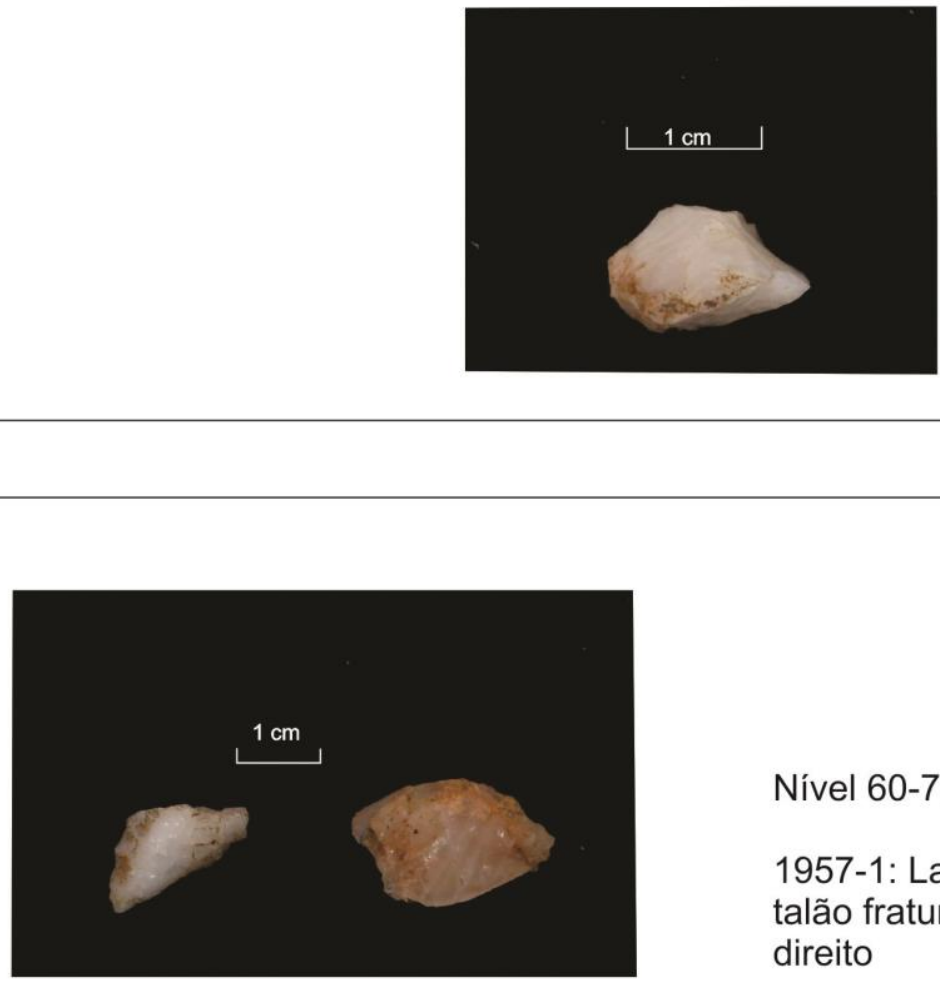

\section{Nível $60-70 \mathrm{~cm}$}

1957-1: Lasca unipolar de quartzo leitoso, talão fraturado. Retoques finos em seu bordo direito

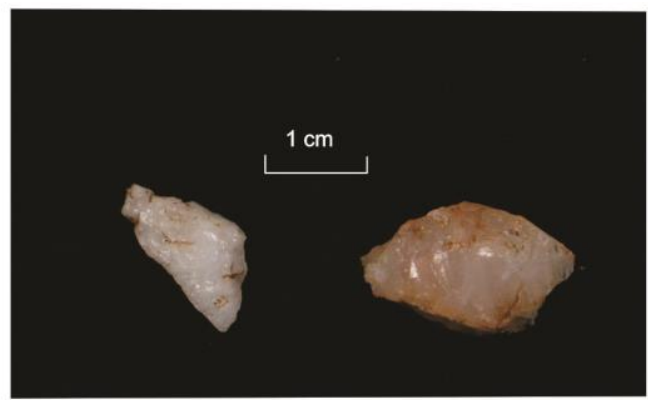

1957-2: Lasca de quartzo policristalino, com retoque sem sua porção distal 


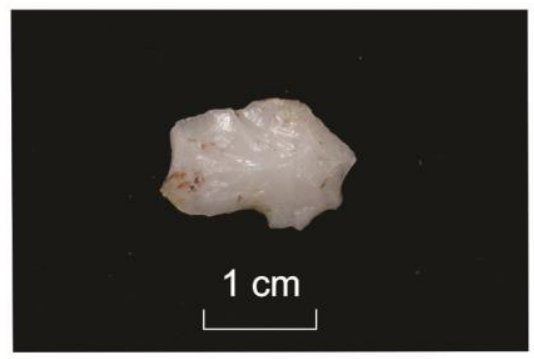

Nível $80-90 \mathrm{~cm}$

1961-1: Fragmento meso-distal de lasca de quartzo leitoso, com retiradas em todo seu contorno.

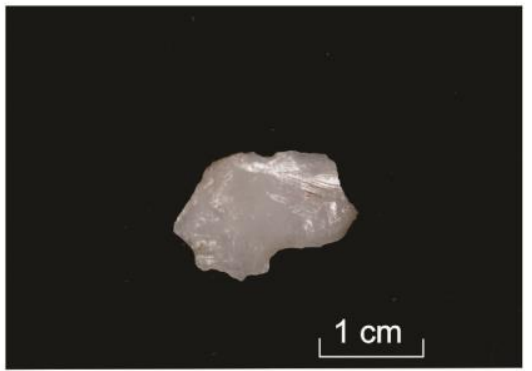

Nível $90-100 \mathrm{~cm}$

1967-2: Fragmento de lasca de gnaisse, provavelmente ruborizada. Possui polimento em uma de suas faces e retoque em um dos seus bordos. $\mathrm{O}$ talão está fraturado
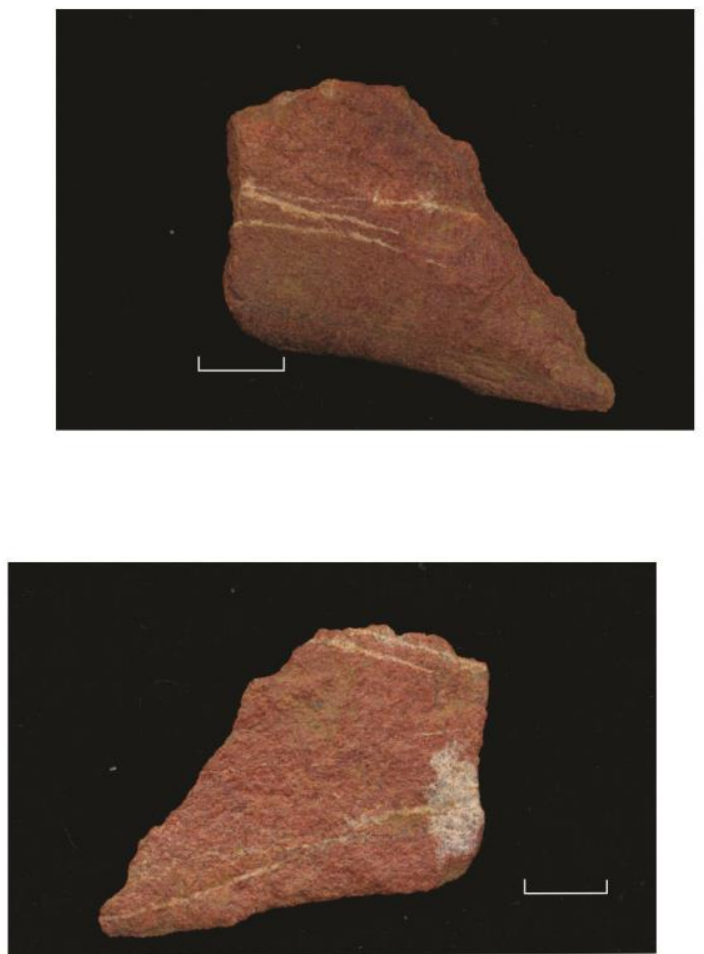

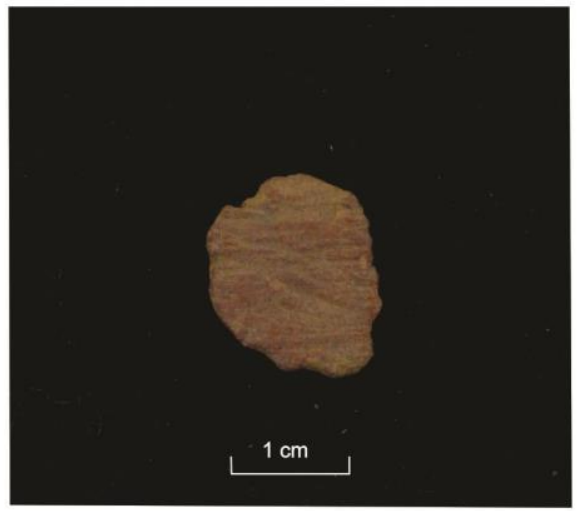

Nível $90-100 \mathrm{~cm}$

1967-1: Fragmento de óxido de ferro, com estrias de abrasão em uma de suas faces. provavelmente utilizada para obtenção de pigmento. 
Nível $120-130 \mathrm{~cm}$

1969- 1: Núcleo de formato discóide esgotado, , provavelmente utilizado como raspador

\section{$1 \mathrm{~cm}$}
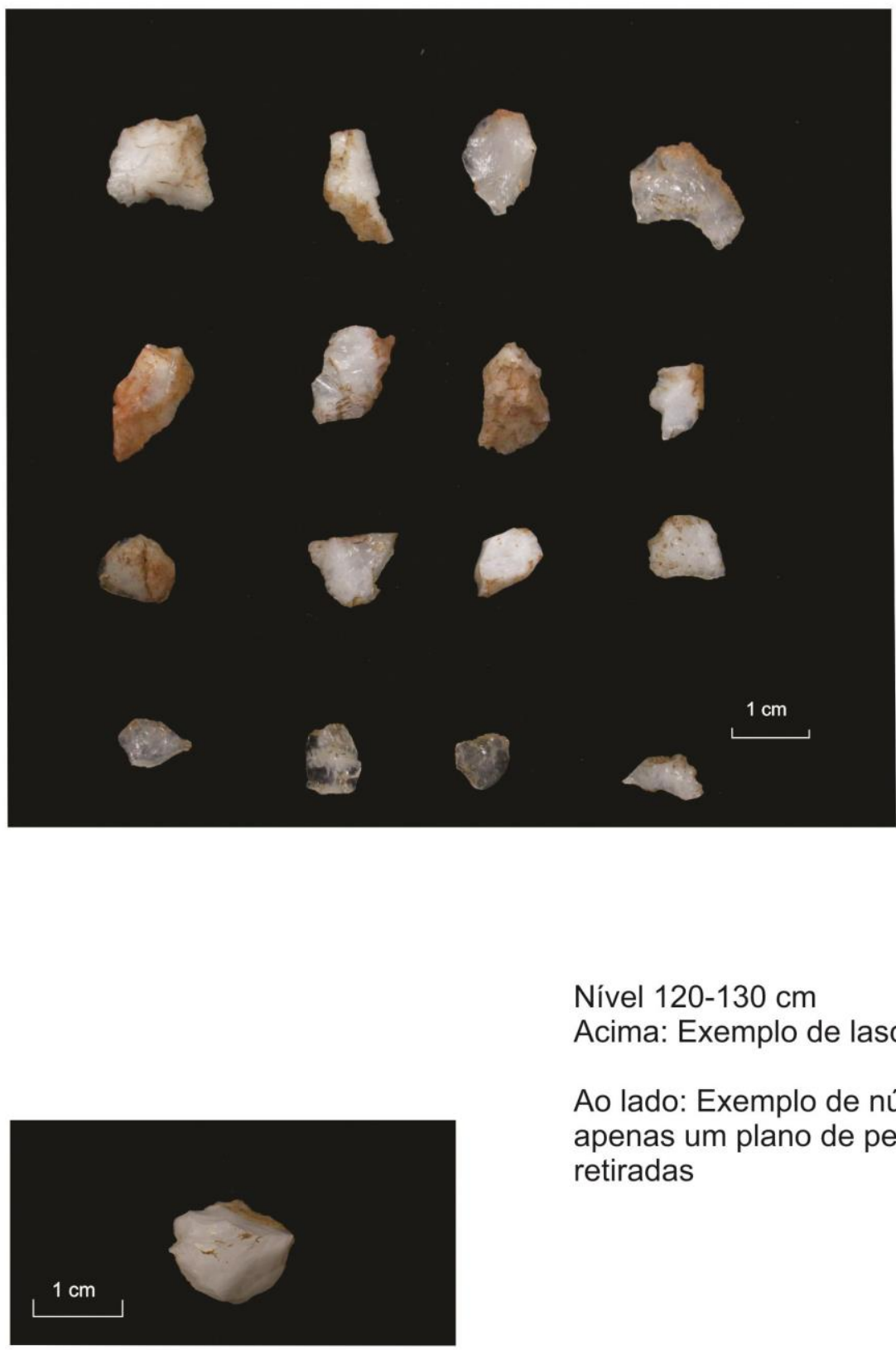

Nível $120-130 \mathrm{~cm}$

Acima: Exemplo de lascas unipolares

Ao lado: Exemplo de núcleo com apenas um plano de percussão, e duas retiradas 
Anexo: Dados da datação do Beta Analythic da Unidade N9882 E10022

BETR BETA ANALYTIC INC. DR. M.A. TAMERS and MR. D.G. HOOD
4985 S.W. 74 COURT

MIAMI, FLORIDA, USA 33155

PH: 305-667-5167 FAX:305-663-0964

beta@radiocarbon.com

\section{REPORT OF RADIOCARBON DATING ANALYSES}

Dr. Eduardo Góes Neves

Report Date: 4/24/2015

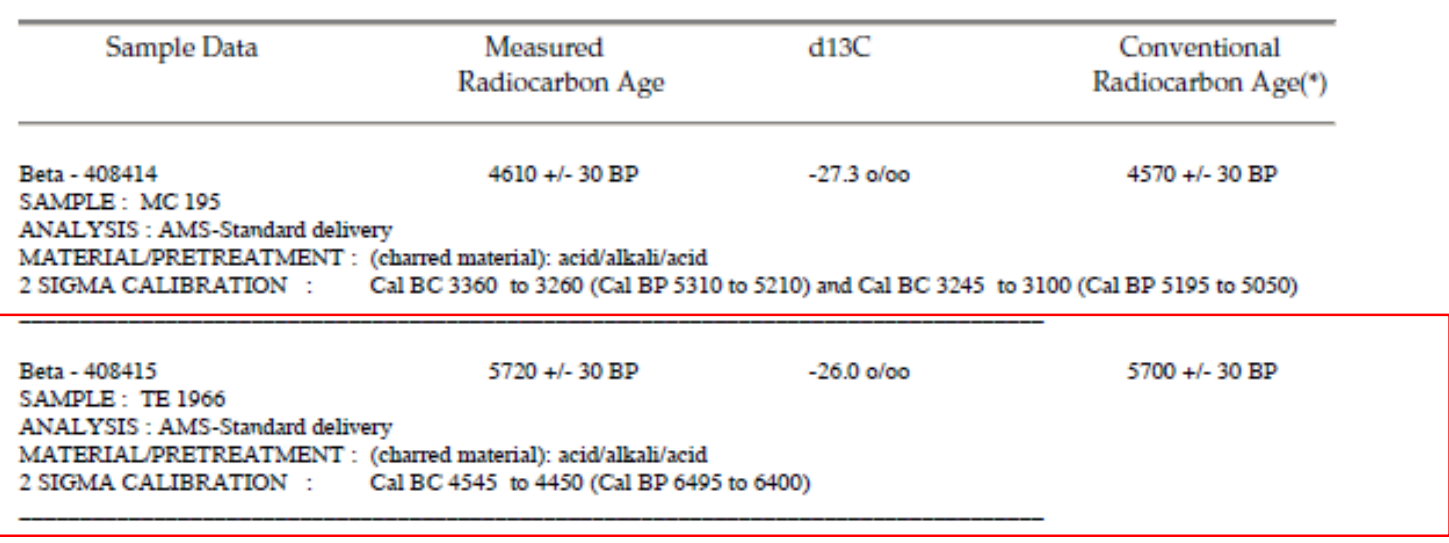




\section{(Variables: $\mathrm{C} 13 / \mathrm{C} 12=-26 \mathrm{o} / 00:$ lab. mult $=1$ )}

Laboratory number Beta-408415

Conventional radiocarbon age $\quad 5700 \pm 30$ BP

Calibrated Result (95\% Probability)

Cal BC 4545 to 4450 (Cal BP 6495 to 6400 )

Intercept of radiocarbon age with calibration curve

Cal BC 4490 (Cal BP 6440)

Calibrated Result ( $68 \%$ Probability)

Cal BC 4520 to 4455 (Cal BP 6470 to 6405 )

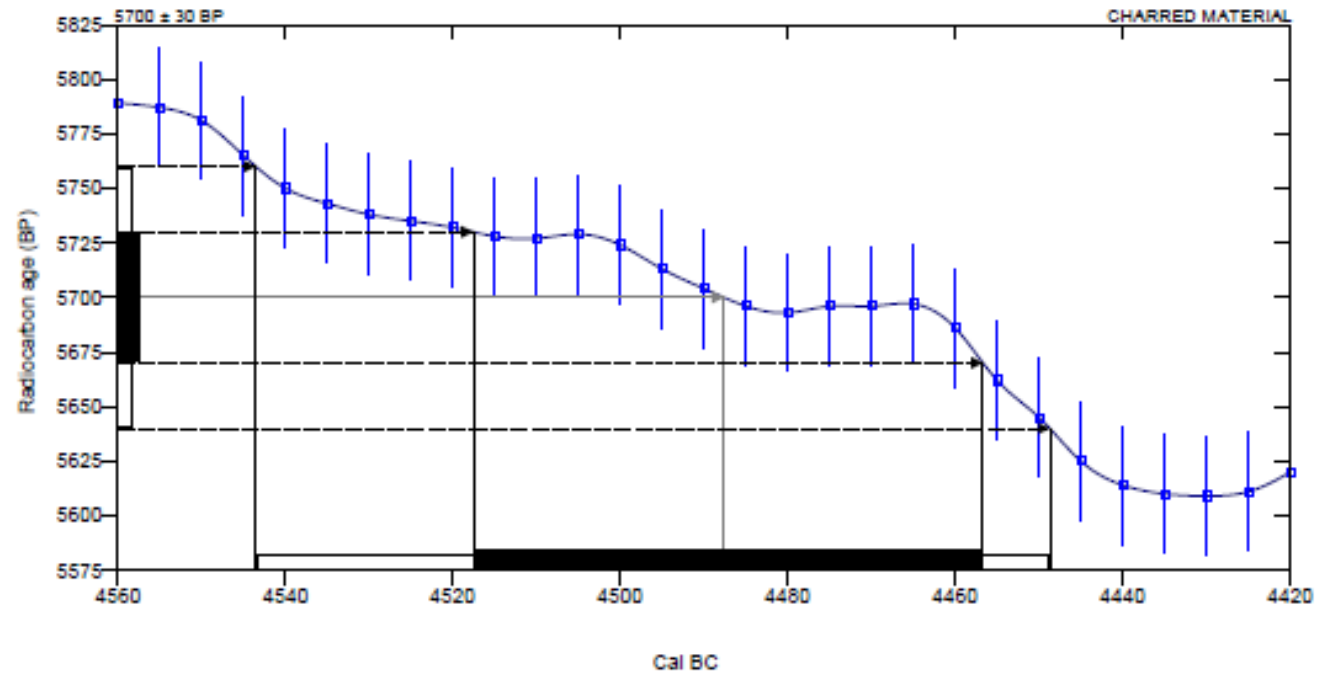

Database used SHCAL13

References

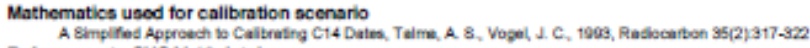

Reforoncos to SHCAL 13 databaso

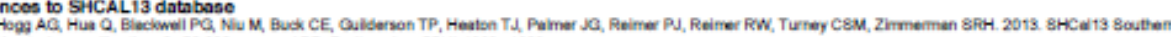

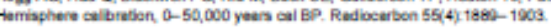

Beta Analytic Radiocarbon Dating Laboratory

4985 3.W. 74th Court Maml, Flonds 33155 * Tel: (305)667-5167 * Fax. (305/663-0964 * Emall: betagradiocarbon.com

Page 12 of 12 
Anexo 14 - Dados brutos da triagem do material lítico - Unidade N9882 E10022

\begin{tabular}{|c|c|c|c|}
\hline PN 1950 & $0-10 \mathrm{~cm}$ & & \\
\hline \multicolumn{4}{|l|}{ Quartzo } \\
\hline & L. Unipo & $\begin{array}{l}\text { Lascas } \\
\text { bip. }\end{array}$ & \begin{tabular}{|l} 
núcleo \\
s
\end{tabular} \\
\hline $\begin{array}{l}\text { menor de } \\
1 \mathrm{~mm}\end{array}$ & 21 & 0 & 7 \\
\hline $\begin{array}{l}\text { maior de } \\
1 \mathrm{~mm}\end{array}$ & 2 & 0 & 1 \\
\hline $\begin{array}{l}\text { maior de } \\
2 \mathrm{~mm}\end{array}$ & 0 & 0 & 0 \\
\hline $\begin{array}{l}\text { maior de } \\
3 \mathrm{~mm}\end{array}$ & 0 & 0 & 0 \\
\hline
\end{tabular}

\begin{tabular}{|l|r|r|r|}
\hline Hialino & & & 3 \\
\hline & & & \\
\hline & $\begin{array}{l}\text { L. } \\
\text { Unipo }\end{array}$ & $\begin{array}{l}\text { Lascas } \\
\text { bip. }\end{array}$ & $\begin{array}{l}\text { núcle } \\
\text { os }\end{array}$ \\
\hline $\begin{array}{l}\text { menor de } \\
1 \mathrm{~mm}\end{array}$ & 3 & 0 & 0 \\
\hline $\begin{array}{l}\text { maior de } \\
1 \mathrm{~mm}\end{array}$ & 0 & 0 & 0 \\
\hline $\begin{array}{l}\text { maior de } \\
2 \mathrm{~mm}\end{array}$ & 0 & 0 & 0 \\
\hline $\begin{array}{l}\text { maior de } \\
3 \mathrm{~mm}\end{array}$ & 0 & 0 & 0 \\
\hline
\end{tabular}

\begin{tabular}{|l|l|l|r|}
\hline Leitoso & & & \\
\hline & & & \\
\hline & $\begin{array}{l}\text { L. } \\
\text { Unipo }\end{array}$ & $\begin{array}{l}\text { Lascas } \\
\text { bip. }\end{array}$ & núcleos \\
\hline $\begin{array}{l}\text { menor de } \\
1 \mathrm{~mm}\end{array}$ & 7 & & \\
\hline $\begin{array}{l}\text { maior de } \\
1 \mathrm{~mm}\end{array}$ & 1 & & 0 \\
\hline $\begin{array}{l}\text { maior de } \\
2 \mathrm{~mm}\end{array}$ & 0 & & 0 \\
\hline $\begin{array}{l}\text { maior de } \\
3 \mathrm{~mm}\end{array}$ & & & 0 \\
\hline
\end{tabular}

PN1951 10-20 cm

\begin{tabular}{l|r|r|r|}
\hline Quartzo & & & \\
\hline & & & \\
\hline & L. Unipo & $\begin{array}{l}\text { Lascas } \\
\text { bip. }\end{array}$ & $\begin{array}{l}\text { núcleo } \\
\text { s }\end{array}$ \\
\hline $\begin{array}{l}\text { menor de } \\
1 \mathrm{~mm}\end{array}$ & 43 & 5 & 0 \\
\hline maior de & 3 & 3 & \\
$1 \mathrm{~mm}$ & & & \\
\hline maior de & 0 & 0 & 0 \\
$2 \mathrm{~mm}$ & 0 & 0 & 0 \\
\hline maior de & & & \\
$3 \mathrm{~mm}$ & & &
\end{tabular}

\begin{tabular}{|l|r|r|r|}
\hline Hialino & & & \\
\hline & & & \\
\hline & $\begin{array}{l}\text { L. } \\
\text { Unipo }\end{array}$ & $\begin{array}{l}\text { Lascas } \\
\text { bip. }\end{array}$ & $\begin{array}{l}\text { núcle } \\
\text { os }\end{array}$ \\
\hline $\begin{array}{l}\text { menor de } \\
1 \mathrm{~mm}\end{array}$ & 5 & 0 & 0 \\
\hline $\begin{array}{l}\text { maior de } \\
1 \mathrm{~mm}\end{array}$ & 0 & 2 & 0 \\
\hline $\begin{array}{l}\text { maior de } \\
2 \mathrm{~mm}\end{array}$ & 0 & 0 & 0 \\
\hline $\begin{array}{l}\text { maior de } \\
3 \mathrm{~mm}\end{array}$ & 0 & 0 & 0 \\
\hline
\end{tabular}

\begin{tabular}{|l|l|l|l|}
\hline Leitoso & & & \\
\hline & & & \\
\hline & $\begin{array}{l}\text { L. } \\
\text { Unipo }\end{array}$ & $\begin{array}{l}\text { Lascas } \\
\text { bip. }\end{array}$ & núcleos \\
\hline $\begin{array}{l}\text { menor de } \\
1 \mathrm{~mm}\end{array}$ & 10 & & \\
\hline $\begin{array}{l}\text { maior de } \\
1 \mathrm{~mm}\end{array}$ & 4 & & 2 \\
\hline $\begin{array}{l}\text { maior de } \\
2 \mathrm{~mm}\end{array}$ & 0 & & 5 \\
\hline $\begin{array}{l}\text { maior de } \\
\text { 3mm }\end{array}$ & 0 & & \\
\hline
\end{tabular}

\section{PN $1952 \quad 20-30 \mathrm{~cm}$}

\begin{tabular}{l|r|r|r|}
\hline Quartzo & & & \\
\hline & L. Unipo & $\begin{array}{l}\text { Lascas } \\
\text { bip. }\end{array}$ & $\begin{array}{l}\text { núcleo } \\
\text { s }\end{array}$ \\
\hline $\begin{array}{l}\text { menor de } \\
1 \mathrm{~mm}\end{array}$ & 15 & 1 & 1 \\
\hline $\begin{array}{l}\text { maior de } \\
1 \mathrm{~mm}\end{array}$ & 25 & 7 & 10 \\
\hline $\begin{array}{l}\text { maior de } \\
2 \mathrm{~mm}\end{array}$ & 0 & 0 & 2 \\
\hline $\begin{array}{l}\text { maior de } \\
3 \mathrm{~mm}\end{array}$ & 0 & 0 & 0 \\
\hline
\end{tabular}

\begin{tabular}{|l|l|r|r|}
\hline Hialino & & & \\
\hline & & & \\
\hline & $\begin{array}{l}\text { L. } \\
\text { Unipo }\end{array}$ & $\begin{array}{l}\text { Lascas } \\
\text { bip. }\end{array}$ & $\begin{array}{l}\text { núcle } \\
\text { os }\end{array}$ \\
\hline $\begin{array}{l}\text { menor de } \\
1 \mathrm{~mm}\end{array}$ & 0 & 0 & 0 \\
\hline $\begin{array}{l}\text { maior de } \\
1 \mathrm{~mm}\end{array}$ & 2 & 0 & 1 \\
\hline $\begin{array}{l}\text { maior de } \\
2 \mathrm{~mm}\end{array}$ & 0 & 0 & 0 \\
\hline $\begin{array}{l}\text { maior de } \\
3 \mathrm{~mm}\end{array}$ & 0 & 0 & 0 \\
\hline
\end{tabular}

\begin{tabular}{|l|r|l|r|}
\hline Leitoso & & & \\
\hline & $\begin{array}{l}\text { L. } \\
\text { Unipo }\end{array}$ & $\begin{array}{l}\text { Lascas } \\
\text { bip. }\end{array}$ & núcleos \\
\hline $\begin{array}{l}\text { menor de } \\
1 \mathrm{~mm}\end{array}$ & 4 & & \\
\hline $\begin{array}{l}\text { maior de } \\
1 \mathrm{~mm}\end{array}$ & 5 & & 1 \\
\hline $\begin{array}{l}\text { maior de } \\
2 \mathrm{~mm}\end{array}$ & 0 & & 1 \\
\hline $\begin{array}{l}\text { maior de } \\
3 \mathrm{~mm}\end{array}$ & 0 & 0 & 0 \\
\hline
\end{tabular}

\begin{tabular}{l|r|r|r|}
\hline PN 1955 & \multicolumn{2}{|l|}{$30-40 \mathrm{~cm}$} & \\
\hline & & & \\
\hline Quartzo & & & \\
\hline & & $\begin{array}{l}\text { Lascas } \\
\text { bip. }\end{array}$ & $\begin{array}{l}\text { núcleo } \\
\text { s }\end{array}$ \\
\hline $\begin{array}{l}\text { menor de } \\
1 \mathrm{~mm}\end{array}$ & 37 & 5 & 8 \\
\hline $\begin{array}{l}\text { maior de } \\
1 \mathrm{~mm}\end{array}$ & 26 & 7 & 17 \\
\hline $\begin{array}{l}\text { maior de } \\
2 \mathrm{~mm}\end{array}$ & 0 & 0 & 3 \\
\hline $\begin{array}{l}\text { maior de } \\
3 \mathrm{~mm}\end{array}$ & 0 & 0 & 0 \\
\hline
\end{tabular}

\begin{tabular}{|l|l|l|l|}
\hline Hialino & & & \\
\hline & & & \\
\hline & $\begin{array}{l}\text { Lnipo } \\
\text { Unip. }\end{array}$ & $\begin{array}{l}\text { Lascas } \\
\text { búcle } \\
\text { os }\end{array}$ \\
\hline $\begin{array}{l}\text { menor de } \\
1 \mathrm{~mm}\end{array}$ & 4 & 0 & 1 \\
\hline $\begin{array}{l}\text { maior de } \\
1 \mathrm{~mm}\end{array}$ & 6 & 0 & 0 \\
\hline $\begin{array}{l}\text { maior de } \\
2 \mathrm{~mm}\end{array}$ & 0 & 1 & 0 \\
\hline $\begin{array}{l}\text { maior de } \\
3 \mathrm{~mm}\end{array}$ & 0 & 0 & 0 \\
\hline
\end{tabular}

\begin{tabular}{|c|c|c|c|}
\hline Leitoso & & & \\
\hline & $\begin{array}{l}\text { L. } \\
\text { Unipo }\end{array}$ & $\begin{array}{l}\text { Lascas } \\
\text { bip. }\end{array}$ & núcleos \\
\hline $\begin{array}{l}\text { menor de } \\
1 \mathrm{~mm}\end{array}$ & 7 & 5 & 1 \\
\hline $\begin{array}{l}\text { maior de } \\
1 \mathrm{~mm}\end{array}$ & 7 & 0 & 4 \\
\hline $\begin{array}{l}\text { maior de } \\
2 \mathrm{~mm}\end{array}$ & 1 & 0 & 0 \\
\hline $\begin{array}{l}\text { maior de } \\
3 \mathrm{~mm}\end{array}$ & 0 & 0 & 0 \\
\hline
\end{tabular}


PN 1956 40-50cm

\begin{tabular}{l|r|r|r|}
\hline Quartzo & & & \\
\hline & & & \\
\hline & L. Unipo & $\begin{array}{l}\text { Lascas } \\
\text { bip. }\end{array}$ & $\begin{array}{l}\text { núcleo } \\
\text { s }\end{array}$ \\
\hline $\begin{array}{l}\text { menor de } \\
1 \mathrm{~mm}\end{array}$ & 125 & 3 & 14 \\
\hline $\begin{array}{l}\text { maior de } \\
1 \mathrm{~mm}\end{array}$ & 72 & 11 & 27 \\
\hline $\begin{array}{l}\text { maior de } \\
2 \mathrm{~mm}\end{array}$ & 6 & 1 & 2 \\
\hline $\begin{array}{l}\text { maior de } \\
3 \mathrm{~mm}\end{array}$ & 0 & 0 & 1 \\
\hline
\end{tabular}

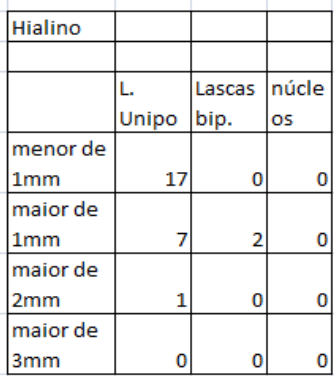

\begin{tabular}{|l|r|r|r|}
\hline Leitoso & & & \\
\hline & & & \\
\hline & $\begin{array}{l}\text { L. } \\
\text { Unipo }\end{array}$ & $\begin{array}{l}\text { Lascas } \\
\text { bip. }\end{array}$ & núcleos \\
\hline $\begin{array}{l}\text { menor de } \\
1 \mathrm{~mm}\end{array}$ & 6 & 0 & 0 \\
\hline $\begin{array}{l}\text { maior de } \\
1 \mathrm{~mm}\end{array}$ & 11 & 2 & 8 \\
\hline $\begin{array}{l}\text { maior de } \\
2 \mathrm{~mm}\end{array}$ & 0 & & \\
\hline $\begin{array}{l}\text { maior de } \\
3 \mathrm{~mm}\end{array}$ & 0 & & \\
\hline
\end{tabular}

PN $1957 \quad 50-60 \mathrm{~cm}$

\begin{tabular}{|l|r|r|l|}
\hline Quartzo & & & \\
\hline & & & \\
\hline & L. Unipo & $\begin{array}{l}\text { Lascas } \\
\text { bip. }\end{array}$ & $\begin{array}{l}\text { núcleo } \\
\text { s }\end{array}$ \\
\hline $\begin{array}{l}\text { menor de } \\
1 \mathrm{~mm}\end{array}$ & 48 & 2 & 5 \\
\hline $\begin{array}{l}\text { maior de } \\
1 \mathrm{~mm}\end{array}$ & 47 & 11 & 20 \\
\hline $\begin{array}{l}\text { maior de } \\
2 \mathrm{~mm}\end{array}$ & 0 & 0 & 2 \\
\hline $\begin{array}{l}\text { maior de } \\
3 \mathrm{~mm}\end{array}$ & 0 & 0 & 0 \\
\hline
\end{tabular}

\begin{tabular}{|l|l|l|l|}
\hline Hialino & & & \\
\hline & & & \\
\hline & $\begin{array}{l}\text { L. } \\
\text { Unipo }\end{array}$ & $\begin{array}{l}\text { Lascas } \\
\text { bip. }\end{array}$ & $\begin{array}{l}\text { núcle } \\
\text { os }\end{array}$ \\
\hline $\begin{array}{l}\text { menor de } \\
1 \mathrm{~mm}\end{array}$ & 6 & 0 & 0 \\
\hline $\begin{array}{l}\text { maior de } \\
1 \mathrm{~mm}\end{array}$ & 5 & 0 & 0 \\
\hline $\begin{array}{l}\text { maior de } \\
2 \mathrm{~mm}\end{array}$ & 0 & 1 & 0 \\
\hline $\begin{array}{l}\text { maior de } \\
\text { 3mm }\end{array}$ & 0 & 0 & 0 \\
\hline
\end{tabular}

\begin{tabular}{|l|l|l|l|}
\hline Leitoso & & & \\
\hline & & & \\
\hline & $\begin{array}{l}\text { L. } \\
\text { Unipo }\end{array}$ & $\begin{array}{l}\text { Lascas } \\
\text { bip. }\end{array}$ & núcleos \\
\hline $\begin{array}{l}\text { menor de } \\
1 \mathrm{~mm}\end{array}$ & 2 & 0 & 0 \\
\hline $\begin{array}{l}\text { maior de } \\
1 \mathrm{~mm}\end{array}$ & 7 & 0 & 1 \\
\hline $\begin{array}{l}\text { maior de } \\
2 \mathrm{~mm}\end{array}$ & 1 & & \\
\hline $\begin{array}{l}\text { maior de } \\
3 \mathrm{~mm}\end{array}$ & 0 & & 0 \\
\hline
\end{tabular}

\section{PN $1958 \quad 60-70 \mathrm{~cm}$}

\begin{tabular}{|l|r|r|r|}
\hline Quartzo & & & \\
\hline & & & \\
\hline L. Unipo & $\begin{array}{l}\text { Lascas } \\
\text { bip. }\end{array}$ & $\begin{array}{l}\text { núcleo } \\
\text { s }\end{array}$ \\
\hline $\begin{array}{l}\text { menor de } \\
\text { maior de }\end{array}$ & 61 & 1 & 7 \\
$1 \mathrm{~mm}$ & 42 & 5 & 16 \\
\hline $\begin{array}{l}\text { maior de } \\
2 \mathrm{~mm}\end{array}$ & 2 & 0 & 1 \\
\hline $\begin{array}{l}\text { maior de } \\
3 \mathrm{~mm}\end{array}$ & 0 & 0 & 0 \\
\hline
\end{tabular}

\begin{tabular}{|l|l|l|l|}
\hline Hialino & & & \\
\hline & $\begin{array}{l}\text { L. } \\
\text { Unipo }\end{array}$ & $\begin{array}{l}\text { Lascas } \\
\text { bip. }\end{array}$ & $\begin{array}{l}\text { núcle } \\
\text { os }\end{array}$ \\
\hline $\begin{array}{l}\text { menor de } \\
1 \mathrm{~mm}\end{array}$ & 3 & 0 & 0 \\
\hline $\begin{array}{l}\text { maior de } \\
1 \mathrm{~mm}\end{array}$ & 4 & & 0 \\
\hline $\begin{array}{l}\text { maior de } \\
2 \mathrm{~mm}\end{array}$ & 0 & 0 & 0 \\
\hline $\begin{array}{l}\text { maior de } \\
\text { 3mm }\end{array}$ & 0 & 0 & 0 \\
\hline
\end{tabular}

\begin{tabular}{|l|l|l|r|}
\hline Leitoso & & & \\
\hline & & & \\
\hline & $\begin{array}{l}\text { L. } \\
\text { Unipo }\end{array}$ & $\begin{array}{l}\text { Lascas } \\
\text { bip. }\end{array}$ & núcleos \\
\hline $\begin{array}{l}\text { menor de } \\
1 \mathrm{~mm}\end{array}$ & 0 & 0 & 0 \\
\hline $\begin{array}{l}\text { maior de } \\
1 \mathrm{~mm}\end{array}$ & 0 & 0 & 0 \\
\hline $\begin{array}{l}\text { maior de } \\
2 \mathrm{~mm}\end{array}$ & 0 & & \\
\hline $\begin{array}{l}\text { maior de } \\
3 \mathrm{~mm}\end{array}$ & 0 & & \\
\hline
\end{tabular}

\section{PN $1960 \quad 70-80 \mathrm{~cm}$}

\begin{tabular}{l|r|r|r|}
\hline Quartzo & & & \\
\hline & & & \\
\hline & L. Unipo & $\begin{array}{l}\text { Lascas } \\
\text { bip. }\end{array}$ & $\begin{array}{l}\text { núcleo } \\
\text { s }\end{array}$ \\
\hline $\begin{array}{l}\text { menor de } \\
1 \mathrm{~mm}\end{array}$ & 38 & 3 & 3 \\
\hline maior de & 54 & 5 & 22 \\
\begin{tabular}{l|r|r} 
mm \\
maior de \\
$2 \mathrm{~mm}$
\end{tabular} & 1 & 0 & 4 \\
\hline maior de & & & \\
$3 \mathrm{~mm}$ & 0 & 0 & 0 \\
\hline
\end{tabular}
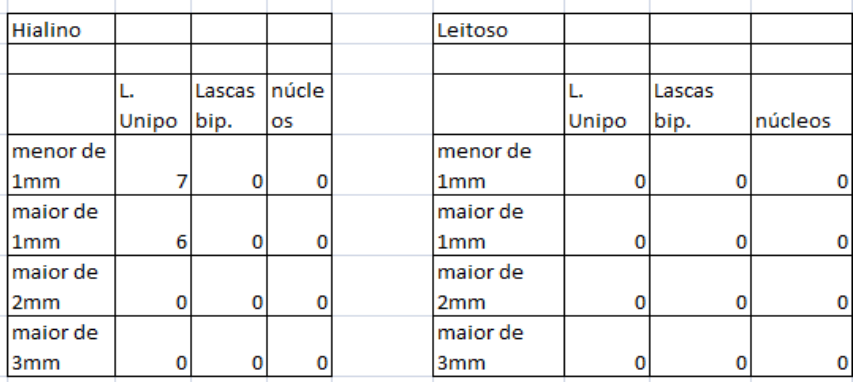

\section{PN $1961 \quad 80-90 \mathrm{~cm}$}
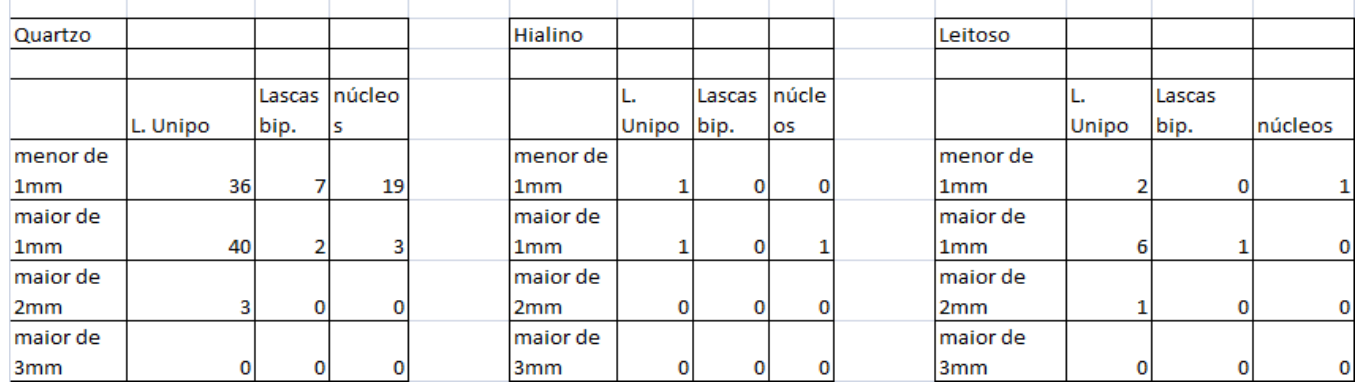
PN $1967 \quad 90-100 \mathrm{~cm}$

\begin{tabular}{|c|c|c|c|}
\hline Quartzo & & & \\
\hline & L. Unipo & \begin{tabular}{|l|}
$\begin{array}{l}\text { Lascas } \\
\text { bip. }\end{array}$ \\
\end{tabular} & $\begin{array}{l}\text { núcleo } \\
\mathrm{s}\end{array}$ \\
\hline $\begin{array}{l}\text { menor de } \\
1 \mathrm{~mm}\end{array}$ & 13 & 1 & 3 \\
\hline $\begin{array}{l}\text { maior de } \\
1 \mathrm{~mm}\end{array}$ & 25 & 3 & 11 \\
\hline $\begin{array}{l}\text { maior de } \\
2 \mathrm{~mm}\end{array}$ & 0 & 0 & 1 \\
\hline $\begin{array}{l}\text { maior de } \\
3 \mathrm{~mm}\end{array}$ & 0 & 0 & 0 \\
\hline
\end{tabular}

PN $1969 \quad 100-110 \mathrm{~cm}$

\begin{tabular}{l|r|r|r|}
\hline Quartzo & & & \\
\hline & & & \\
\hline & L. Unipo & $\begin{array}{l}\text { Lascas } \\
\text { bip. }\end{array}$ & $\begin{array}{l}\text { núcleo } \\
\text { s }\end{array}$ \\
\hline $\begin{array}{l}\text { menor de } \\
1 \mathrm{~mm}\end{array}$ & 10 & 1 & 0 \\
\hline $\begin{array}{l}\text { maior de } \\
1 \mathrm{~mm}\end{array}$ & 6 & 0 & 6 \\
\hline $\begin{array}{l}\text { maior de } \\
2 \mathrm{~mm}\end{array}$ & 0 & 0 & 0 \\
\hline $\begin{array}{l}\text { maior de } \\
3 \mathrm{~mm}\end{array}$ & 0 & 0 & 0 \\
\hline
\end{tabular}

\section{PN $1970 \quad 110-120 \mathrm{~cm}$}

\begin{tabular}{l|r|r|l|}
\hline Quartzo & & & \\
\hline & L. Unipo & $\begin{array}{l}\text { Lascas } \\
\text { bip. }\end{array}$ & $\begin{array}{l}\text { núcleo } \\
s\end{array}$ \\
\hline $\begin{array}{l}\text { menor de } \\
1 \mathrm{~mm}\end{array}$ & 0 & 0 & 0 \\
\hline $\begin{array}{l}\text { maior de } \\
1 \mathrm{~mm}\end{array}$ & 10 & 1 & 5 \\
\hline $\begin{array}{l}\text { maior de } \\
2 \mathrm{~mm}\end{array}$ & 0 & 0 & 0 \\
\hline $\begin{array}{l}\text { maior de } \\
3 \mathrm{~mm}\end{array}$ & 0 & 0 & 0 \\
\hline
\end{tabular}

PN $1972 \quad 120-130 \mathrm{~cm}$

\begin{tabular}{l|r|r|r|}
\hline Quartzo & & & \\
\hline & & & \\
\hline & L. Unipo & $\begin{array}{l}\text { Lascas } \\
\text { bip. }\end{array}$ & $\begin{array}{l}\text { núcleo } \\
\text { s }\end{array}$ \\
\hline $\begin{array}{l}\text { menor de } \\
1 \mathrm{~mm}\end{array}$ & 28 & 4 & 1 \\
\hline $\begin{array}{l}\text { maior de } \\
1 \mathrm{~mm}\end{array}$ & 11 & 1 & 7 \\
\hline $\begin{array}{l}\text { maior de } \\
2 \mathrm{~mm}\end{array}$ & 0 & 0 & 0 \\
\hline $\begin{array}{l}\text { maior de } \\
3 \mathrm{~mm}\end{array}$ & 0 & 0 & 0 \\
\hline
\end{tabular}

\begin{tabular}{|l|l|l|l|}
\hline Hialino & & & \\
\hline & & & \\
\hline & $\begin{array}{l}\text { L. } \\
\text { Unipo }\end{array}$ & $\begin{array}{l}\text { Lascas } \\
\text { bip. }\end{array}$ & $\begin{array}{l}\text { núcle } \\
\text { os }\end{array}$ \\
\hline $\begin{array}{l}\text { menor de } \\
1 \mathrm{~mm}\end{array}$ & 3 & 0 & 0 \\
\hline $\begin{array}{l}\text { maior de } \\
1 \mathrm{~mm}\end{array}$ & 0 & 0 & 0 \\
\hline $\begin{array}{l}\text { maior de } \\
2 \mathrm{~mm}\end{array}$ & 0 & 0 & 0 \\
\hline $\begin{array}{l}\text { maior de } \\
3 \mathrm{~mm}\end{array}$ & 0 & 0 & 0 \\
\hline
\end{tabular}

\begin{tabular}{|l|l|l|l|}
\hline Hialino & & & \\
\hline & & & \\
\hline & $\begin{array}{l}\text { L. } \\
\text { Unipo }\end{array}$ & $\begin{array}{l}\text { Lascas } \\
\text { bip. }\end{array}$ & $\begin{array}{l}\text { núcle } \\
\text { os }\end{array}$ \\
\hline $\begin{array}{l}\text { menor de } \\
1 \mathrm{~mm}\end{array}$ & 2 & & 0 \\
\hline $\begin{array}{l}\text { maior de } \\
1 \mathrm{~mm}\end{array}$ & 3 & & 0 \\
\hline $\begin{array}{l}\text { maior de } \\
2 \mathrm{~mm}\end{array}$ & 0 & 0 & 0 \\
\hline $\begin{array}{l}\text { maior de } \\
3 \mathrm{~mm}\end{array}$ & 0 & 0 & 0 \\
\hline
\end{tabular}

\begin{tabular}{|c|c|c|c|}
\hline Leitoso & & & \\
\hline & $\begin{array}{l}\text { L. } \\
\text { Unipo }\end{array}$ & $\begin{array}{l}\text { Lascas } \\
\text { bip. }\end{array}$ & núcleos \\
\hline $\begin{array}{l}\text { menor de } \\
1 \mathrm{~mm} \\
\end{array}$ & 0 & 0 & 0 \\
\hline \begin{tabular}{|l|} 
maior de \\
$1 \mathrm{~mm}$ \\
\end{tabular} & 0 & 0 & 0 \\
\hline \begin{tabular}{|l} 
maior de \\
$2 \mathrm{~mm}$
\end{tabular} & 0 & 0 & 0 \\
\hline $\begin{array}{l}\text { maior de } \\
3 \mathrm{~mm}\end{array}$ & 0 & 0 & 0 \\
\hline
\end{tabular}

\begin{tabular}{|l|l|l|l|}
\hline Hialino & & & \\
\hline & & & \\
\hline & $\begin{array}{l}\text { L. } \\
\text { Unipo }\end{array}$ & $\begin{array}{l}\text { Lascas } \\
\text { bip. }\end{array}$ & $\begin{array}{l}\text { núcle } \\
\text { os }\end{array}$ \\
\hline $\begin{array}{l}\text { menor de } \\
1 \mathrm{~mm}\end{array}$ & 1 & 0 & 0 \\
\hline $\begin{array}{l}\text { maior de } \\
1 \mathrm{~mm}\end{array}$ & 0 & 0 & 0 \\
\hline $\begin{array}{l}\text { maior de } \\
2 \mathrm{~mm}\end{array}$ & 0 & 0 & 0 \\
\hline $\begin{array}{l}\text { maior de } \\
3 \mathrm{~mm}\end{array}$ & 0 & 0 & 0 \\
\hline
\end{tabular}

\begin{tabular}{|c|c|c|c|}
\hline Leitoso & & & \\
\hline & $\begin{array}{l}\text { L. } \\
\text { Unipo }\end{array}$ & $\begin{array}{l}\text { Lascas } \\
\text { bip. }\end{array}$ & núcleos \\
\hline $\begin{array}{l}\text { menor de } \\
1 \mathrm{~mm}\end{array}$ & 0 & 0 & 0 \\
\hline \begin{tabular}{|l} 
maior de \\
$1 \mathrm{~mm}$ \\
\end{tabular} & 0 & 0 & 0 \\
\hline \begin{tabular}{|l|} 
maior de \\
$2 \mathrm{~mm}$
\end{tabular} & 0 & 0 & 0 \\
\hline $\begin{array}{l}\text { maior de } \\
3 \mathrm{~mm}\end{array}$ & 0 & 0 & 0 \\
\hline
\end{tabular}

\begin{tabular}{|l|l|l|l|}
\hline Hialino & & & \\
\hline & & & \\
\hline & $\begin{array}{l}\text { L. } \\
\text { Unipo }\end{array}$ & $\begin{array}{l}\text { Lascas } \\
\text { bip. }\end{array}$ & $\begin{array}{l}\text { núcle } \\
\text { os }\end{array}$ \\
\hline $\begin{array}{l}\text { menor de } \\
1 \mathrm{~mm}\end{array}$ & 2 & 0 & 0 \\
\hline $\begin{array}{l}\text { maior de } \\
1 \mathrm{~mm}\end{array}$ & 3 & 0 & 0 \\
\hline $\begin{array}{l}\text { maior de } \\
2 \mathrm{~mm}\end{array}$ & 0 & 0 & 0 \\
\hline $\begin{array}{l}\text { maior de } \\
3 \mathrm{~mm}\end{array}$ & 0 & 0 & 0 \\
\hline
\end{tabular}

\begin{tabular}{|c|c|c|c|}
\hline Leitoso & & & \\
\hline & $\begin{array}{l}\text { L. } \\
\text { Unipo }\end{array}$ & $\begin{array}{l}\text { Lascas } \\
\text { bip. }\end{array}$ & núcleos \\
\hline $\begin{array}{l}\text { menor de } \\
1 \mathrm{~mm}\end{array}$ & 3 & 0 & 0 \\
\hline $\begin{array}{l}\text { maior de } \\
1 \mathrm{~mm}\end{array}$ & 4 & 0 & 1 \\
\hline $\begin{array}{l}\text { maior de } \\
2 \mathrm{~mm}\end{array}$ & 0 & 0 & 0 \\
\hline $\begin{array}{l}\text { maior de } \\
3 \mathrm{~mm}\end{array}$ & 0 & 0 & 0 \\
\hline
\end{tabular}


Anexo 15 - Sítio Oficina Lítica Laje - localização e detalhe de imagem aérea
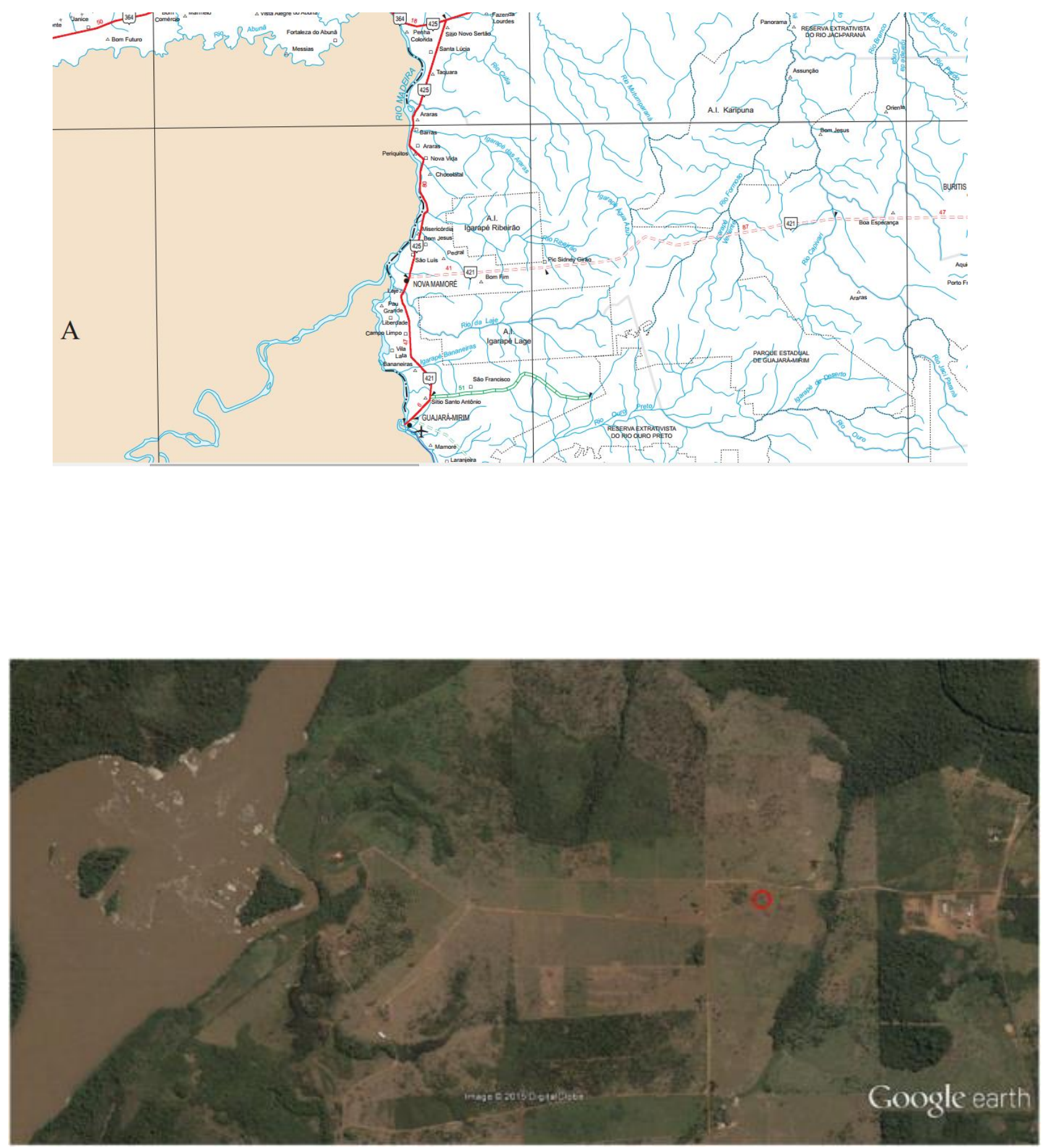
Anexo 16 - Estratos de publicações de Miller sobre as industrias líticas pré-cerâmicas do alto rio madeira

\section{Complexo Periquitos}

Miller 1987. Inventário Arqueológico da bacia e sub-bacias do Rio Madeira: 1974-1987, CNEC

Paleoindígena

Sítios: Periquitos / RO-GM-12

Posicionado em sedimentos do final do Pleistoceno e encoberto por sedimentos inconsolidados holocênicos que forma o leito das barrancas lindantes ao Rio Madeira, na Cachoeira dos Periquitos. A espessura da camada cultural é desconhecida. A posição é a sobreposta ao bedrock, pela margem direita. As dimensões horizontais e forma são desconhecidas, mas a extensão ao longo do dique marginal ultrapassa os 800 metros, desocntinuamente, em focos. Ocorrem restos de troncos vegetais em fossilização.

Material Lítico

Lascas e lâminas finas e pequenas (15-34mm) de quartzo e sílex, resultantes de percussão direta dura, com evidências de micro-lascamento por pressão e descontínuo. Núcleos de quartzo e sílex com ou sem mossas de percussão. Algumas lascas de rochas diversas estão profunda e intensamente alteradas, mas ainda conservam resquícios das cristas interlascamentos. Afora essas rochas, os nódulos de quartzo e sílex conhecidos são pequenos. O tamanho das lâmicas e lascas maiores parece estar condicionado ao tamanho da matéria-prima. Contudo, a quantidade de evidências é pequena (39) para conclusões seguras

Miller, 1987 Pesquisas arqueológicas paleoindígenas no Brasil Ocidental Estudios Atacameños, No. 8,Investigaciones Paleoindias AL sur de La línea Ecuatorial, pp. 37$\underline{61}$

Descrição dos artefatos do Complexo Periquitos:

O maquinário - dragas e outros - penetram nos horizontes sedimentares argilosos e arenosos ate o leito granítico do rio sugando tudo a seu alcance: sedimentos, concreções, seixos, etc., restos da biota - fosseis ou não - mutilando ou simplesmente destruindo e transformando em pó, nas moendas. Em uma das oportunidades que nos foram dadas de acompanhar esse trabalho de mineração, obteve-se das peneiras de balsa um biface lítico lanceolado com 7,2 X 2,6 x 1,2 cm em matéria prima extremamente alterada, mas sem duvida resultante de um lascamento por percussão. Nessa oportunidade ainda resultaram algumas lascas e pequenos seixos em quartzito, sem retoque. Essas evidencias quer de atividade cultural ou não, fosseis da paleobiota e do homem, sempre apresentam-se encobertas parcial ou totalmente por concreções lateritico-argilosa ou argilo-arenosa densamente cimentadas, com pedregulho pequeno (raramente ate 4,5 x 2,2 x 1,8 cm).

Datações: Para o Complexo Periquitos não ha datações. Apenas é possível uma estimativa crono-sedimentar onde suas evidencias materiais se encontram em transição pleisto/holocenica, ou seja ao redor de 12.000-13.000 anos a.P.

Miller, 1992. Adaptação agrícola Pré-Historica no Alto Rio Madeira. In Prehistoria Sudamericana: nuevas perspectivas. Meggers, B.J.(Ed). Taraxacum-Washington

(...)com base na sequência de colunas estatográficas de diques marginais desnudados ao longo da calha do Alto Madeira, em especial na coluna Belmonte a justo juzante de Porto 
Velho, onde se localiza o sítio RO-PV-107: Cai n’Água (...). As evidências do Paleoíndio encontram-se na porção justo e abaixo do paleocanal com datação de 11.940 AP.

Deste e de outros dois sítios (RO-JP-06 e RO-GM-12), foram recuperados alguns percutores com evidências de uso, lascas e um biface lanceolado ou pré-forma em quartzito, sílex e outras rochas bastante alterados, que caracterizam o complexo cultural Periquitos.

\section{Complexo Girau}

Miller 1987. Inventário Arqueológico da bacia e sub-bacias do Rio Madeira: 1974-1987, CNEC

Pré-cerâmico arcaico

Sítios:

RO-JP-01: Teotônio

RO-JP-06: Girau

RO-GM-3: Pederneira-2

RO-GM-5: Ribeirão

RP-GM-6: Paredão

RO-GM-12: Periquitos

As espessuras das camadas culturais e o número destas, em cada sítio, é desconhecido. EM RO-GM-12: Periquitos, a camada estéril entre os complexos Periquitos e Girau apresenta uma espessura acima dos 2 metros. A camada cultural está situada na base dos sedimentos incosolidados holocênicos que formam o fundo superior e as margens do Alto Madeira, com uma cronologia aproximada relativa entre 6.000 e 9.000 A.P. As dimensões verticais e horizontais bem como a forma dos sítios são desconhecidas, porém, a extensão ao longo dos diques marginais varia de 20 a 140 metros descontínuos, em focos de poucos metros. Ocorrem restos de troncos vegetais em fossilização

Material Lítico:

Lascas de quartzo e sílex e rochas graníticas, obtidas por percussão dura direta, com poucas evidências de retoque sob pressão. Ocorre micro lascamento descontínuo como provável indício de uso. O pequeno tamanho das lascas (11-26mm) e raras lâminas (18$32 \mathrm{~mm}$ ) parece estar condicionado ao tamanho dos nódulos de sílex e quartzo, presentemente conhecidos. Dois núcleos esgotados em rocha granítica podem ter sido utilizados como raspadores altos. EM geral, esse tipo de matéria prima está profundamente alterado, mas ainda são observadas as cristas inter-lascamento.

Miller, 1992. Adaptação agrícola Pré-Historica no Alto Rio Madeira. In Prehistoria

Sudamericana: nuevas perspectivas. Meggers, B.J. (Ed). Taraxacum-Washington

O Complexo Girau, estratigraficamente situado no Holoceno Médio, com lascas, percutores, núcleos e possíveis raspadores em quartzo, sílex e rochas graníticas alteradas.

\section{Frase Itapipoca}

Miller 1987. Inventário Arqueológico da bacia e sub-bacias do Rio Madeira: 1974-1987, $\underline{C N E C}$

Fase pré-cerâmica arcaica, representada por dois sítios arqueológicos, de tradição a ser determinada.

Sítios:

RO-PV-20: Monte Castelo

RO-PV-59: Itapipoca

Os sítios formam uma delgada camada sobre e quase em contato com a rocha granítica, cerca de 3,6 a 4,1 m abaixo da superfície. A forma é desconhecida. O material lítico 
cultural ocorre ao longo de 32 e 56m ao longo do dique marginal em erosão. Pela posição estratigráfica, é possível uma cronologia entre 6000 e 8000 anos AP

Material lítico: Lascas de sílex, quartzo e rochas cristalinas de pequenas a grandes, finas a grossas, com e sem retoques. Núcleos esgotados e raspadores circulares e laterais. Percutores com mossas de percussão, pequenos e médios

Estatigraficamente no Holoceno Antigo, com lascas e percutores de quartzito e sílex, raspadores e pré-formas bifaciais em rochas alteradas.

\section{Fase Pacatuba}

Sítios: RO-PV-32: Lima

RO-PV-52: Cachoeirinha

Os sítios estão em contato e sob sítios cerâmicos da fase Jamari. Formato e dimensões horizontais em determinação. Espessura da camada cultura: 40 a $200 \mathrm{~cm}$, de 80 a 280 e 90 a $130 \mathrm{~cm}$ de profundidade. A porção superior das camadas culturais é de coloração cinza escuro e a inferior igual ao solo estéril, ou amarelado. Situam-se de 10 a $20 \mathrm{~m}$ acima das cheias do igarapé e rio. Estratigraficamente é esperada uma cronologia entre 2.000 e 5.000 AP. para essa fase pré-cerâmica.

Material lítico: Grande quantidade de pequenas lascas de quartzo, poucas de sílex e rochas cristalinas, finas e grossas, com algumas evidências de micro-lascamento. Núcleos lascados e percutores. Grande quantidade de seixos irregulares de várias rochas sem evidências de modificação de uso.

Portador de lascas, percutores e calhaus de quartzito e sílex, pedras-bigorna, núcleos e, no final da sequencia, polidores, tocas lâmicas de machado lascadas bifacialmente, microlascas em quartzo e lajotas com depressões picoteadas, situando-se cronoligamente desde

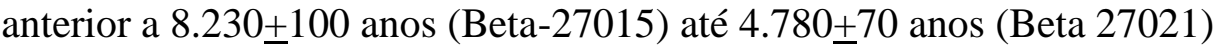

